\title{
Disturbance and Recovery of Intertidal Mixed Seagrass Communities
}

\author{
Meredith Ferdie Muth \\ Charlottesville, Virginia
}

Master's of Science, Florida International University, 2002
Bachelors of Science, University of West Florida, 1998

A Dissertation presented to the Graduate Faculty of the University of Virginia in Candidacy for the Degree of

Doctor of Philosophy

Department of Environmental Sciences

University of Virginia

December, 2011

Karen J. McGlathery (co-advisor)

Joseph C. Zieman (co-advisor)

Herman H. Shugart

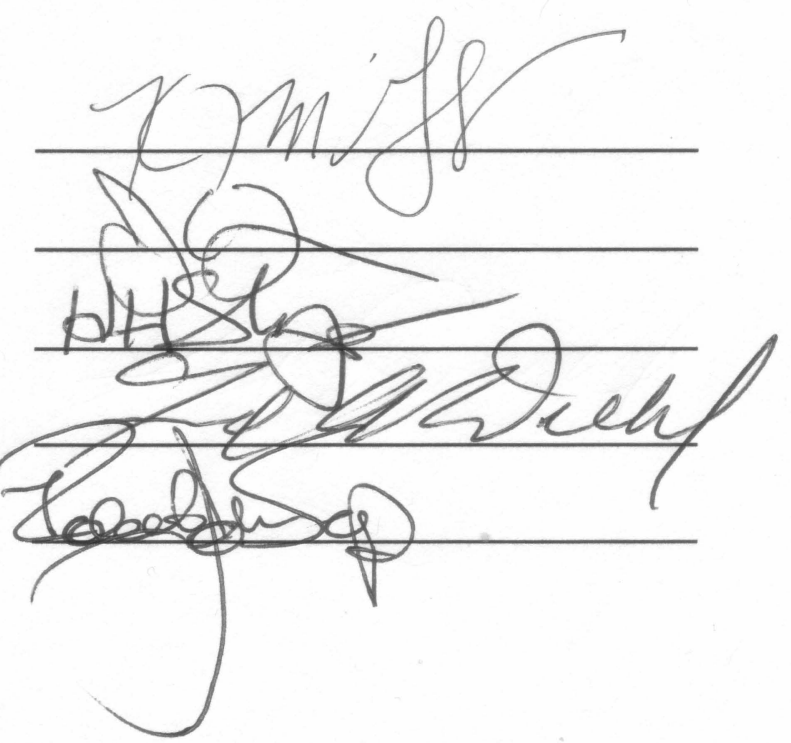

Fred A. Diehl (Representative of the graduate faculty)

Robert J. Swap (Out of discipline representative) 


\begin{abstract}
Disturbances are a key driver in determining the structure and function of the ecological landscape by altering resource availability, community composition and species interactions. For seagrass habitats, most research has focused on subtidal temperate or subtropical systems. Because tropical systems tend to have higher species diversity and are exposed to more types of disturbances, we have a weak understanding of how species-rich intertidal seagrasses recover from different types of disturbances or how these disturbances influence habitat heterogeneity within the landscape.
\end{abstract}

This dissertation investigated the responses, including recovery, of mixed-species intertidal seagrass communities to disturbances at the population, community and landscape level. Key findings include: (1) both macro-scale (tidal gradient) and microscale (disturbance) factors influence seagrass zonation and species diversity patterns across the intertidal landscape in the species-rich Indo-Pacific region; (2) seagrass recolonization in mixed species intertidal meadows is complex, suggesting that recovery prediction using two dimensional seagrass succession models is limited and should incorporate a third dimension - elevation changes produced by specific disturbance types and placement along a tidal gradient; (3) infauna abundance and diversity does not return to original levels even when seagrass biomass returns to pre-disturbance levels, suggesting that the return of ecosystem functions such as habitat utilization may lag behind plant recovery and that monitoring of above-ground plant components is not an accurate indication of full community recovery; (4) changes in sediment organic content 
following seagrass removal in intertidal meadows is not an important factor in smallscale recovery, which differs from experimental studies in subtidal seagrass habitats that found negative affects on seagrass growth; (5) intertidal seagrass meadows are highly dynamic, and the creation of bare gaps within vegetated areas by disturbances can influence habitat heterogeneity at local and landscape scales; and (6) small-size gaps created by disturbances can persist for years and in some cases even expand, and therefore should be included in studies of spatial patterns and landscape dynamics. These findings build upon our general understanding of disturbance ecology in seagrass ecosystems, underline differences between subtidal and intertidal systems, and have applications to prediction efforts and restoration activities in seagrass ecosystems throughout the world. 


\section{Table of Contents}

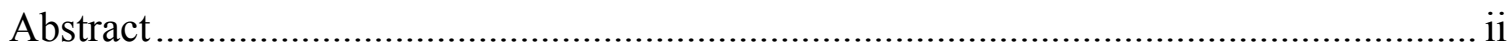

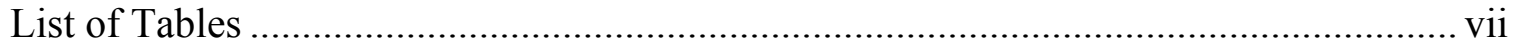

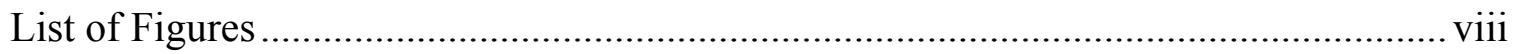

Chapter One: Introduction to Seagrass Disturbance and Recovery ................................. 1

Plant Patterns: Factors regulating seagrass distribution and abundance ................................... 1

Plant Dynamics: Disturbance and seagrass recovery .......................................................... 3

Landscape Dynamics: Role of disturbance on seagrass heterogeneity and diversity............... 16

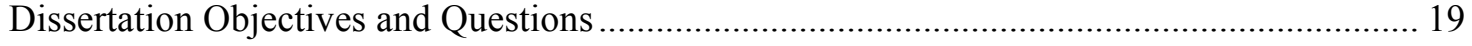

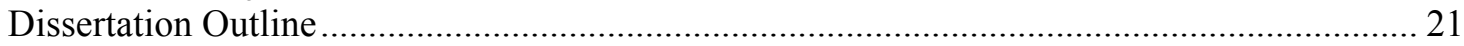

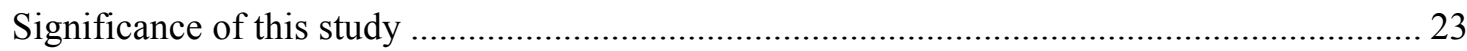

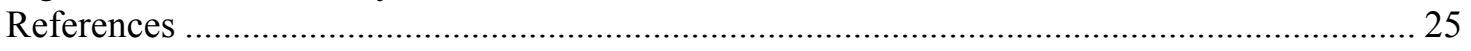

Chapter Two: Factors regulating seagrass species diversity and co-existence across an

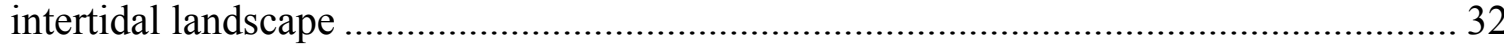

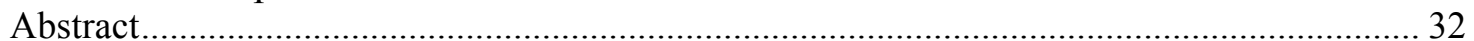

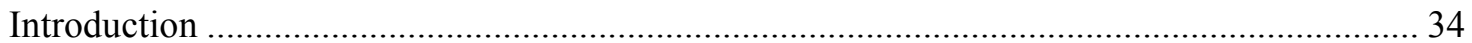

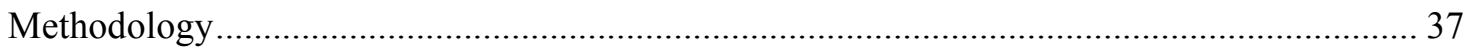

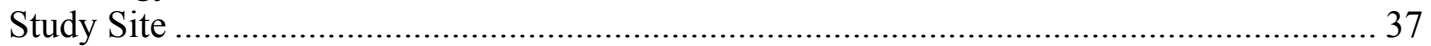

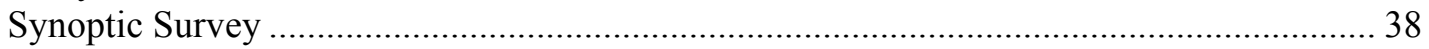

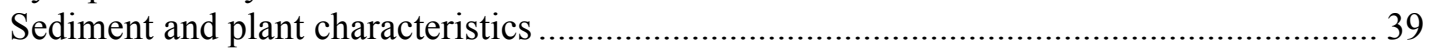

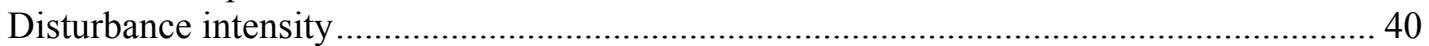

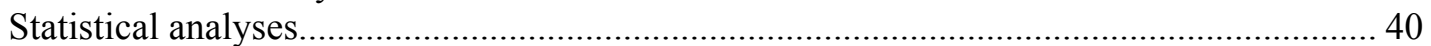

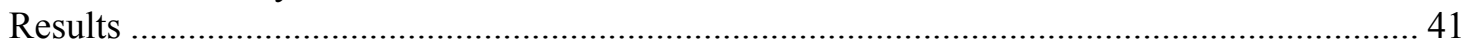

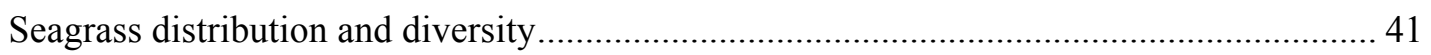

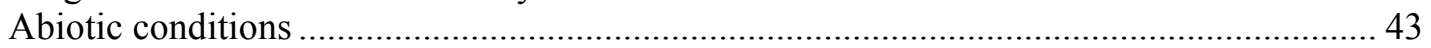

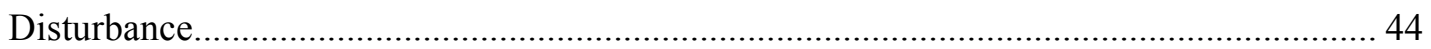

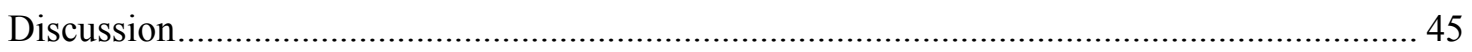

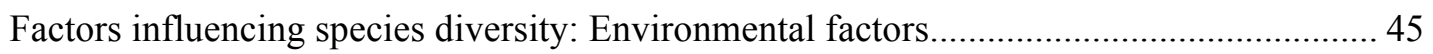

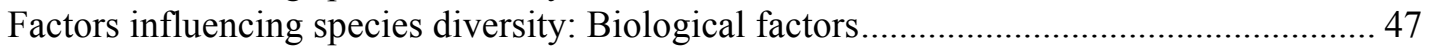

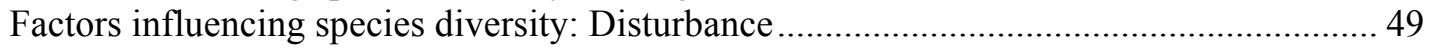

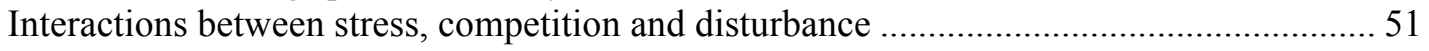

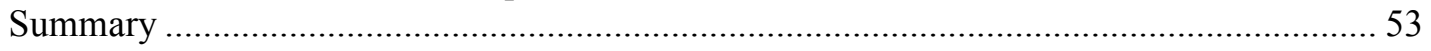

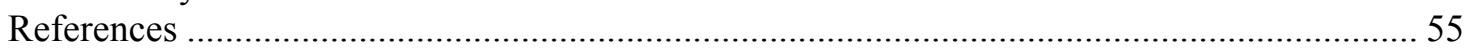

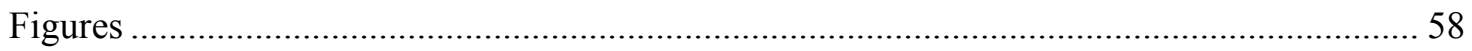

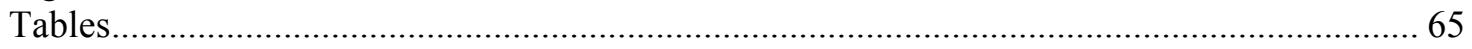

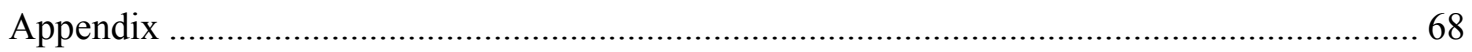

Chapter Three: Disturbance type and tidal placement affect recovery patterns of soft-

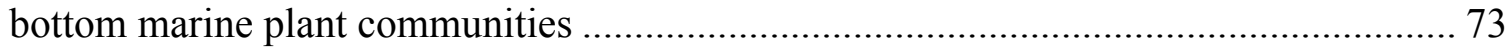

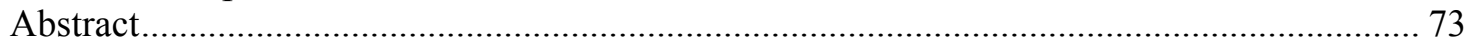

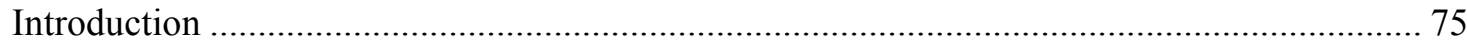

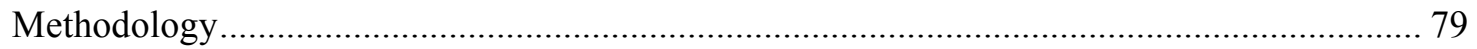

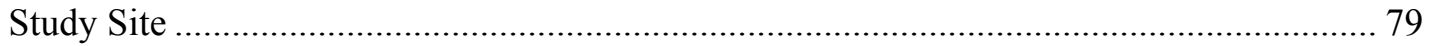

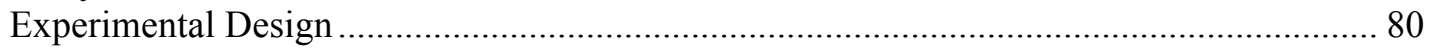




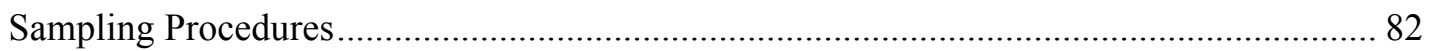

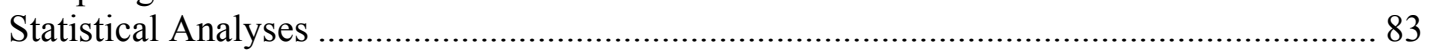

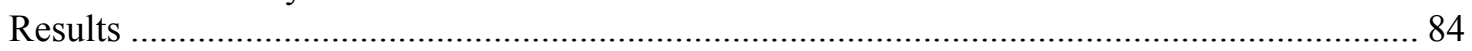

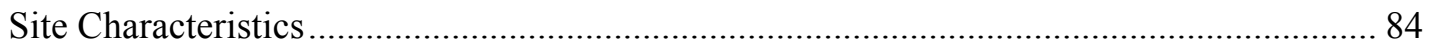

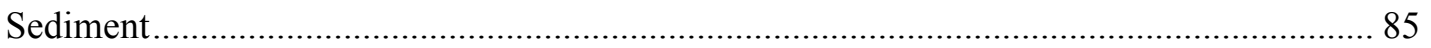

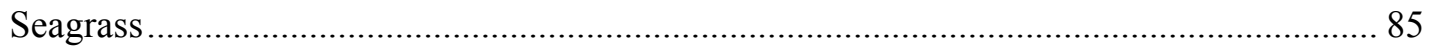

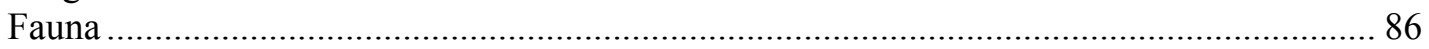

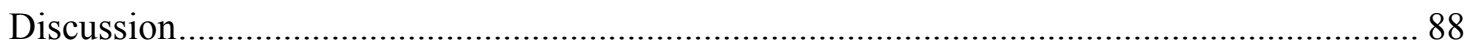

Disturbance Resilience as a function of life history strategies and plant morphology ......... 88

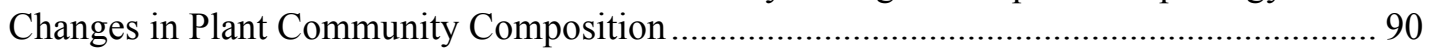

Consumer Control as a Factor in Disturbance Recovery ................................................... 92

Ecosystem Functions: Primary Productivity and Fauna Habitat Utilization.......................... 94

Implications for Changing Disturbance Regimes and Restoration Efforts ........................... 95

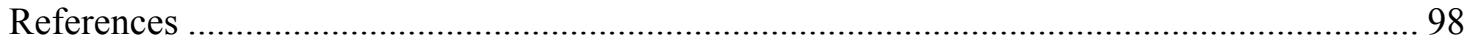

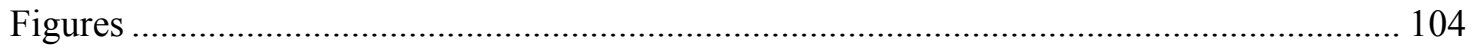

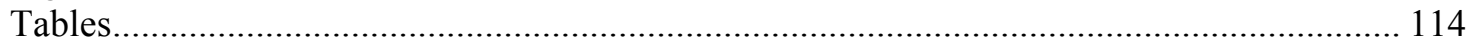

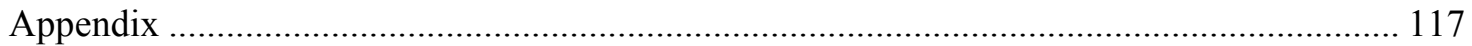

Chapter Four: Seagrass recovery following experimental changes in sediment organic

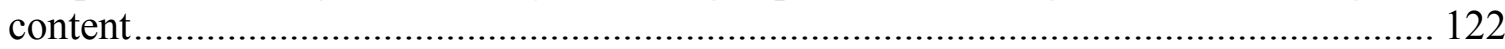

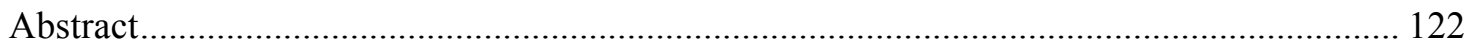

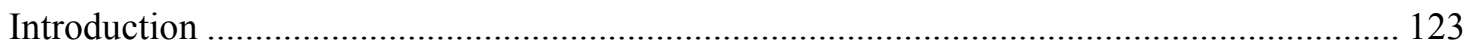

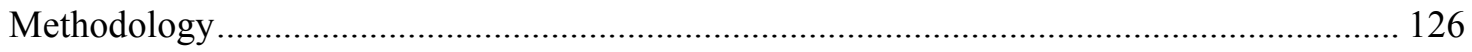

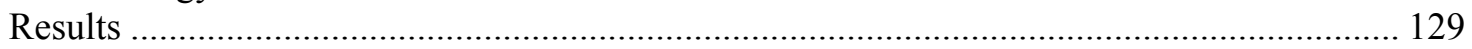

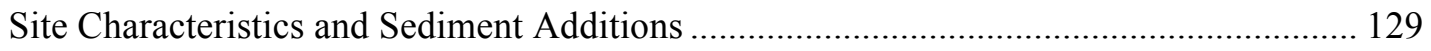

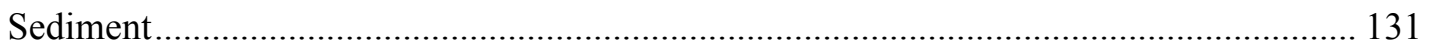

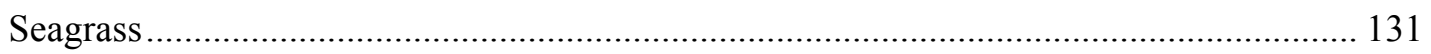

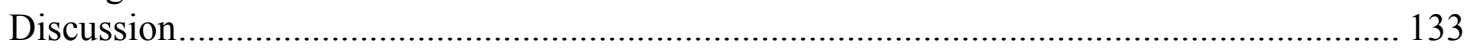

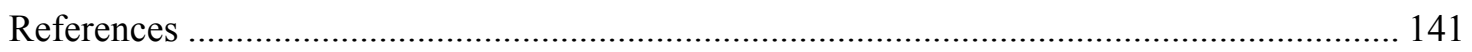

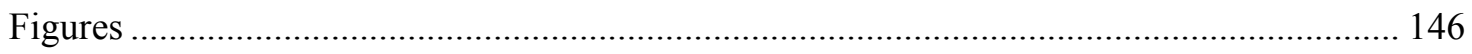

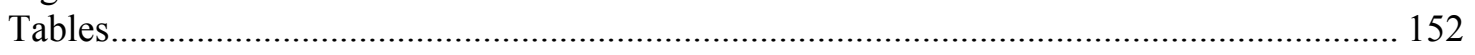

Chapter Five: Spatial and temporal dynamics of gap creation within seagrass meadows

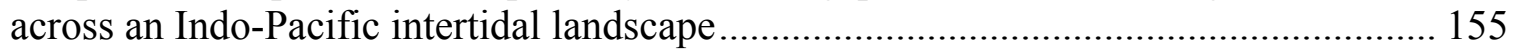

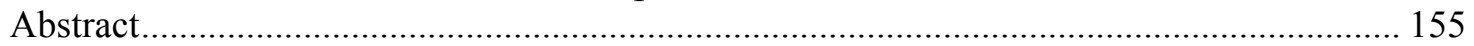

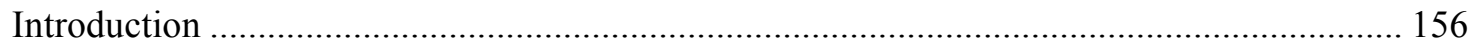

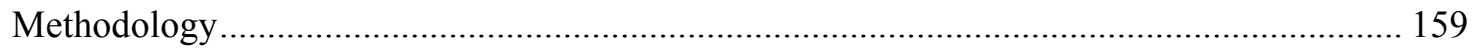

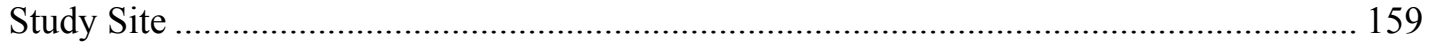

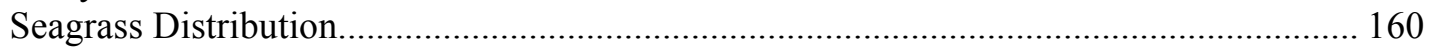

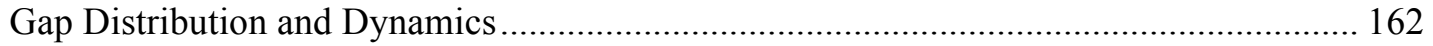

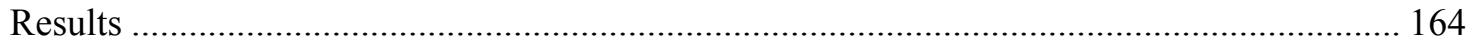

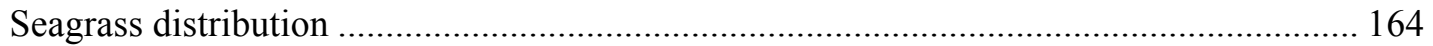

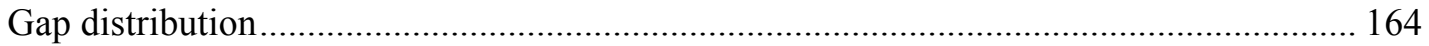

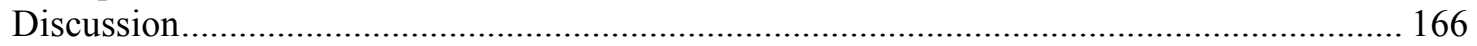

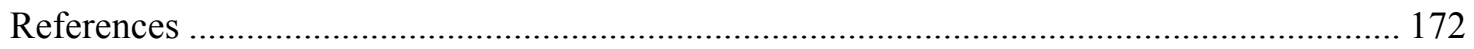

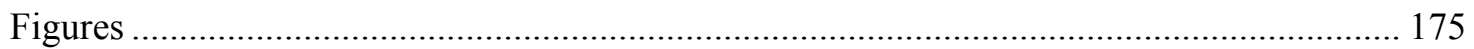

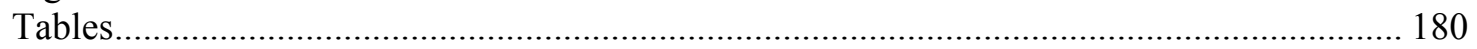

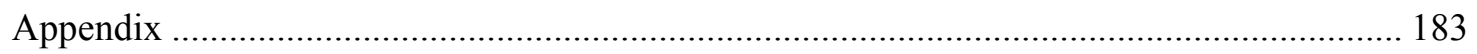




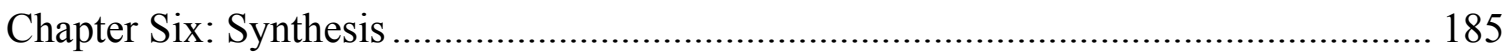

Plant Patterns: Factors Regulating Seagrass Distribution and Abundance …........................ 185

Plant Dynamics: The Role of Disturbance and Seagrass Recovery ..................................... 187

Landscape Dynamics: Disturbance Influence on Seagrass Heterogeneity .............................. 191

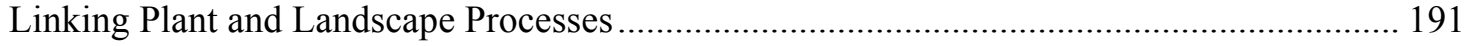




\section{List of Tables}

Table 1.1. Examples of disturbances reported for seagrasses, their impact on the plant, and resulting changes in the seagrass meadow.... 5

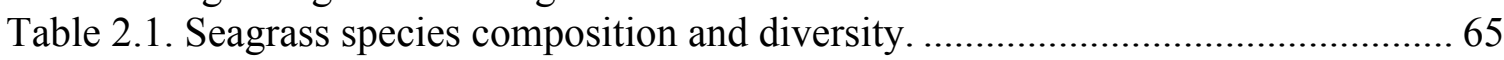

Table 2.2. Descriptive data on abiotic parameters collected at survey sites with seagrass

present. Seagrass nutrients are from leaf tissues of Thalassia testudinum ...................... 66

Table 2.3. Mean number of disturbances per site based on size classes and disturbance type for each intertidal zone................................................................................. 67

Table 3.1. Summary of water, sediment and seagrass characterists for each intertidal site.

Table 3.2. ANOVA table for repeated measures analysis of seagrass species shoot density over time. 115

Table 3.3. Comparison of seagrass and fauna parameters for control (C), burial (B) and removal $(\mathrm{R})$ disturbance treatments at each site after 20 months............................ 116

Table 4.1. Physical characteristics of the three intertidal sites. ................................... 152

Table 4.2. Sources of sediment for treatment applications....................................... 153

Table 5.1. Seagrass classification map and accuracy assessment results. ..................... 180

Table 5.2. Total gap area $\left(\mathrm{m}^{2}\right)$ within seagrass meadows based on tidal location and percent change in area between the 2006 and 2008 imagery....................................... 180 Table 5.3. Percent change of gap behavior between 2006 and 2008 based on intertidal zone and gap size.

Table 5.4. Descriptive statistics for large-scale gap area $\left(\mathrm{m}^{2}\right)$ within seagrass meadows based on tidal location. 


\section{List of Figures}

Figure 1.1. Comparison of reported succession patterns (species replacement over time) for subtidal Caribbean and Indo-Pacific Species following a disturbance.

Figure 1.2. Relative colonization potential of seagrass species in East Africa................ 11

Figure 1.3. Theoretical seagrass distribution integrating intertidal placement and type of

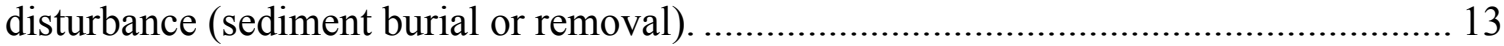

Figure 1.4. Theoretical succession sequences of intertidal seagrass following burial or

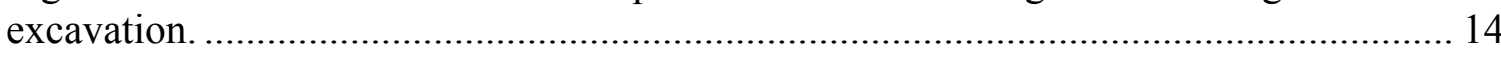

Figure 1.5. Illustration of how the size and number of disturbances affect landscape

heterogeneity in seagrass meadows. ................................................................... 17

Figure 1.6. Incomplete conceptual model describing relationships between disturbance

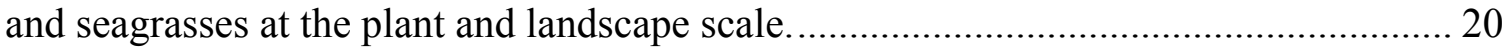

Figure 2.1. Map of Inhaca Island with survey sites. ................................................ 58

Figure 2.2. Frequency of sites based on (a) species richness (number of seagrass species)

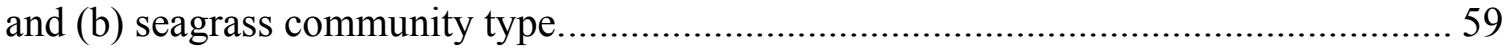

Figure 2.3. Seagrass community type along a tidal gradient. ...................................... 60

Figure 2.4. Seagrass (species richness and abundance) and disturbance (extent and

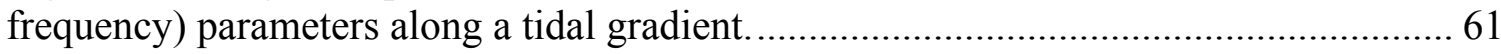

Figure 2.5. Total number of sediment burial and removal disturbances based on

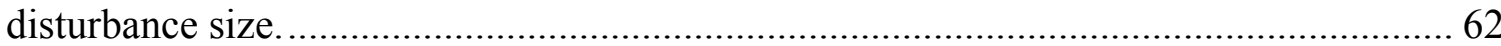

Figure 2.6. Model of relationships between seagrass diversity and disturbance along a

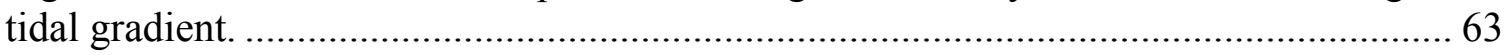

Figure 3.1. Map of Inhaca island and disturbance experiment sites........................... 104

Figure 3.2. Profile of common flora and fauna composition at experimental sites....... 105

Figure 3.3. Experimental design of the disturbance experiment. ................................. 106

Figure 3.4. Changes in mean sediment depth change relative to pre-disturbance levels.107 Figure 3.5. Changes in mean sediment organic content relative to pre-disturbance levels.

Figure 3.6. Seagrass shoot density over time by species and disturbance treatment..... 109

Figure 3.7. Recovery of individual seagrass species compared to pre-disturbance levels.

Figure 3.8. Total seagrass biomass and areal productivity 20 months following the disturbance.

Figure 3.9. Response of fauna community 20 months following the disturbance.......... 112 Figure 3.10. Summary of results by intertidal site (upper, middle, lower) and treatment (burial, removal). ................................................................................................... 113

Figure 4.1. Map of Inhaca island and disturbance experiment sites............................ 146

Figure 4.2. Time series of sediment changes during the sediment organic enrichment

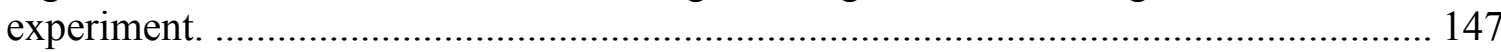

Figure 4.3. Sediment properties at the end of the one year experiment......................... 148

Figure 4.4. Time series of seagrass shoot density changes during the experiment. ....... 149

Figure 4.5. Seagrass shoot density at the end of the one year experiment. .................. 150 
Figure 4.6. Time series of seagrass canopy height ( $80 \%$ of tallest leaf) changes during the experiment. 151

Figure 5.1. Map of Inhaca Island

Figure 5.2. Fishnet distribution of sample grid cells $(50 \mathrm{~m}$ x $50 \mathrm{~m})$ across the intertidal landscape. 176

Figure 5.3. Classification map of seagrass distribution (intertidal and subtidal) using 2006 imagery.

Figure 5.4. Frequency of grid cells with a percentage of area composed of bare gaps. . 178 Figure 5.5. Percentage of area composed of gaps within seagrass meadows by tidal location as determined with 2006 and 2008 satellite imagery................................... 178

Figure 5.6. Gap dynamics from $2006-2008$. 179

Figure 6.1. Completed conceptual model describing relationships between disturbance and seagrasses at the plant and landscape scales. 


\section{Chapter One: Introduction to Seagrass Disturbance and Recovery}

The main objectives of this chapter are to: 1) review our general understanding of disturbance and recovery for seagrass habitats, 2) provide a brief overview of how disturbances can influence seagrass landscape patterns and processes, and 3) present the outline for the dissertation chapters.

\section{Plant Patterns: Factors regulating seagrass distribution and abundance}

The foundation for many ecological studies is the investigation of processes that regulate species distribution and abundance across different spatial and temporal scales. Early research on marine plant community structure emphasized the role of the physical environment and biological interactions. At the end-points along an environmental gradient, species distribution is often restricted by physical stress such as wave energy on rocky intertidal zones (Lewis 1964). Biological interactions such as competition, predation and herbivory also influence species distribution and abundance and can play a strong role in marine plant community structure (Connell 1972) such as determining macroalgae distribution on coral reefs (Hay 1997).

Physical and biological disturbances can also act as a key process in regulating marine plant community structure (Pickett and White 1985, Sousa 2001, Johnson and Miyanishi 2007). However, the role of disturbance is not always straightforward and often interacts with other processes, such as by creating open spaces that may alter the outcome of 
competition between two species due to changes in resource availability. Some attempts have been made to incorporate these three processes (stress, competition, and disturbance) into models that describe plant distribution patterns. One theoretical model is the Philip Grime's C-S-R (Competitor-Stress-Ruderal) Triangle (Grime 1977) that classifies plant functional types based on life strategy tradeoffs along relative intensities of stress, competition and disturbance. For example, species that are ruderal (fast growth rates and high seed production) are predicted to be competitively dominant in areas with low stress intensity and high disturbance intensity.

Seagrass is a term used to describe rooted marine flowering plant species that are found exclusively in shallow submerged marine habitats, primarily on soft-bottom areas. Early research on factors controlling seagrass distribution and zonation patterns focused on physio-chemical gradients such as light (Dennison 1987), salinity and temperature (Livingston et al. 1998). Later research was directed towards additional processes including bottom-up forces such as nutrient limitation (e.g.Lee and Dunton 2000, Ferdie and Fourqurean 2004), top-down forces such as grazing (e.g.Williams 1988, Valentine and Heck 1991), or the interaction between these two forces (e.g.McGlathery 1995, Heck et al. 2000). While affects of different physical stressors on seagrass distribution and abundance patterns is relatively well understood, less research has been conducted on the role of competition and disturbance. 
Despite the well-acknowledged role of natural disturbances in regulating and structuring other marine communities, especially rocky intertidal zones (Dayton 1971, Sousa 1979), disturbance is often neglected when describing key processes that influence seagrass distribution patterns and community structure. Seagrass communities are ideal candidates for the testing of theories of disturbance ecology in natural ecosystems. Their location in shallow coastal systems throughout the world (McRoy and McMillan 1977) in conjunction with their relative immobility and proximity to shore makes them particularly susceptible to natural and anthropogenic disturbances. There are strong practical reasons to study seagrass disturbance because of growing concerns that habitat degradation and global decline of seagrasses (Orth et al. 2006, Waycott et al. 2009) may have negative impacts on important coastal processes such as primary production (Zieman 1985, Duarte and Chiscano 1999), nursery and habitat for secondary production (Beck et al. 2001), organic carbon production and export (Heck et al. 2008), biodiversity (Hemminga and Duarte 2000), and nutrient cycling (Marbà et al. 2006).

\section{Plant Dynamics: Disturbance and seagrass recovery}

\section{Disturbances in seagrass habitats}

Disturbance in the context of this dissertation is defined as any relatively discrete event in time that disrupts ecosystem, community, or population structure and that results in changes of resources, substrate availability, or the physical environment (Pickett and White 1985). Seagrass habitats are strongly influenced by numerous types of natural and 
anthropogenic disturbances that vary in size, timing and intensity, especially in tropical regions (Carruthers et al. 2002). These range from large-scale natural events such as storms (Fourqurean and Rutten 2004) to small-scale biological events such as severe grazing (Rose et al. 1999). The roles of non-trophic biological disturbances, such as bioturbation or foraging activity, are less understood but can have significant impacts in many seagrass systems (Suchanek 1983, Valentine et al. 1994, Townsend and Fonseca 1998). Anthropogenic physical disturbances such as boat prop scaring (Zieman 1976, Fonseca et al. 2004, Kirsch et al. 2005) and dredging (Thrush and Dayton 2002, Erftemeijer and Lewis 2006) are increasing in frequency and represent a considerable share of seagrass disturbance studies. A summary of different disturbances identified in seagrass communities is listed in Table 1.1. 


\begin{tabular}{|c|c|c|c|c|}
\hline & $\begin{array}{c}\text { Disturbance } \\
\text { Agent }\end{array}$ & $\begin{array}{l}\text { Direct Impact on } \\
\text { Seagrass Plant }\end{array}$ & Change & Examples \\
\hline \multirow{5}{*}{$\begin{array}{l}\text { PHYSICAL - } \\
\text { Natural }\end{array}$} & $\begin{array}{l}\text { Storm waves and } \\
\text { currents }\end{array}$ & $\begin{array}{l}\text { Detached or } \\
\text { broken }\end{array}$ & Create new gaps & $\begin{array}{l}\text { Kirkman and } \\
\text { Kuo, } 1990\end{array}$ \\
\hline & $\begin{array}{l}\text { Wave or current- } \\
\text { borne sediment }\end{array}$ & Abraided or buried & Create new gaps & $\begin{array}{l}\text { Preen et al. } \\
1995\end{array}$ \\
\hline & Ice & $\begin{array}{l}\text { Abraded, crushed } \\
\text { or detached }\end{array}$ & Create new gaps & Short 1983 \\
\hline & $\begin{array}{l}\text { Tectonic uplifting of } \\
\text { substrate }\end{array}$ & $\begin{array}{l}\text { Increased aerial } \\
\text { exposure and } \\
\text { dessication }\end{array}$ & $\begin{array}{l}\text { Decrease } \\
\text { biomass }\end{array}$ & $\begin{array}{l}\text { Johansen } \\
1971\end{array}$ \\
\hline & $\begin{array}{l}\text { Extended aerial } \\
\text { exposure }\end{array}$ & $\begin{array}{l}\text { Injured/killed by } \\
\text { desiccation, heat } \\
\text { or UV radiation }\end{array}$ & $\begin{array}{l}\text { Decrease } \\
\text { biomass or } \\
\text { create new gaps }\end{array}$ & Bell et al. 1999 \\
\hline \multirow{3}{*}{$\begin{array}{l}\text { PHYSICAL - } \\
\text { Anthropogenic }\end{array}$} & $\begin{array}{l}\text { Boat prop and } \\
\text { anchor scars }\end{array}$ & $\begin{array}{l}\text { Abraded, crushed } \\
\text { or detached }\end{array}$ & Create new gaps & Fonseca 2004 \\
\hline & Dredging & $\begin{array}{l}\text { Abraded, crushed } \\
\text { or detached }\end{array}$ & $\begin{array}{l}\text { Create new gaps } \\
\text { and/or increase } \\
\text { turbidity }\end{array}$ & $\begin{array}{l}\text { Thrush and } \\
\text { Dayton } 2002\end{array}$ \\
\hline & Trawling & $\begin{array}{l}\text { Abraded, crushed } \\
\text { or detached }\end{array}$ & Create new gaps & $\begin{array}{l}\text { Thrush and } \\
\text { Dayton } 2002\end{array}$ \\
\hline \multirow{4}{*}{$\begin{array}{l}\text { BIOLOGICAL } \\
\text { - Natural }\end{array}$} & $\begin{array}{l}\text { Accumulation of } \\
\text { dislodged plant } \\
\text { material (living or } \\
\text { dead) }\end{array}$ & $\begin{array}{l}\text { Buried, smothered } \\
\text { or shaded }\end{array}$ & $\begin{array}{l}\text { Reduce light to } \\
\text { benthos; alter } \\
\text { biogeochemistry }\end{array}$ & $\begin{array}{l}\text { Holmquist } \\
1997\end{array}$ \\
\hline & $\begin{array}{l}\text { Bioturbation: } \\
\text { sediment } \\
\text { reworking by } \\
\text { infaunal burrowers }\end{array}$ & $\begin{array}{l}\text { Buried and } \\
\text { suffocated }\end{array}$ & $\begin{array}{l}\text { Create new gaps } \\
\text { by burial }\end{array}$ & $\begin{array}{l}\text { Suchanek } \\
1983\end{array}$ \\
\hline & $\begin{array}{l}\text { Grazing activity } \\
\text { (e.g. manatees, } \\
\text { turtles, urchins) }\end{array}$ & $\begin{array}{l}\text { Detached or } \\
\text { broken }\end{array}$ & Open canopy & $\begin{array}{l}\text { Alcoverra et al. } \\
2002\end{array}$ \\
\hline & $\begin{array}{l}\text { Sediment } \\
\text { excavation by } \\
\text { foraging predators } \\
\text { or large burrowers }\end{array}$ & $\begin{array}{l}\text { Displaced, } \\
\text { uprooted, or buried } \\
\text { and suffocated }\end{array}$ & $\begin{array}{l}\text { Create new gaps } \\
\text { by excavation }\end{array}$ & $\begin{array}{l}\text { Valentine et al. } \\
1994\end{array}$ \\
\hline \multirow{2}{*}{$\begin{array}{l}\text { BIOLOGICAL } \\
\text { - Natural / } \\
\text { Anthropogenic }\end{array}$} & Algal blooms & $\begin{array}{l}\text { Suffocated by } \\
\text { reduced oxygen }\end{array}$ & Reduce biomass & Valelia 1997 \\
\hline & Invasive species & $\begin{array}{l}\text { Smothering by } \\
\text { competition }\end{array}$ & $\begin{array}{l}\text { Change } \\
\text { composition }\end{array}$ & Larned 2003 \\
\hline
\end{tabular}

Table 1.1. Examples of disturbances reported for seagrasses, their impact on the plant, and resulting changes in the seagrass meadow. 
Seagrass community succession following a disturbance

There is a rich and diverse body of literature that addresses disturbance recovery from both theoretical and applied perspectives (see Picket and White, 1985 for review).

Succession in this dissertation refers to the directional change in community structure and functioning through time following a perturbation. Early models of succession emphasized a highly predictable sequence of communities that leads to a stable and selfregulated 'climax' state that will dominate in the absence of disturbance (Clements 1916). Subsequent theories placed a greater emphasis upon the individual responses of different species to environmental conditions, where the community composition is heavily influenced by species interactions and their ability to modify the environment (Gleason 1917). Advances in modern ecology tend to support the notion that more than one succession trajectory exists for most plant communities and less emphasis is placed on a single climax community type.

Far less attention has been directed towards succession for seagrasses compared to other marine communities, such as rocky intertidal and coral reef systems. Succession, in the context of species replacement, is not relevant to many seagrass communities across the globe, especially in temperate zones. Temperate regions tend to be dominated by a single species (e.g., Posidonia oceanica in the Mediterranean, Zostera Marina in the Atlantic ocean), so there are limited opportunities for species replacement over time. Overall seagrass diversity is quite low with approximately 66 species worldwide (den Hartog and 
Kuo 2006). Tropical regions have more extant seagrass species, with the highest diversity found in the Indo-Pacific region.

Prevailing theory regarding seagrass recovery following disturbance in mixed-species habitats borrows heavily from the facilitation model of succession. This model suggests that recently disturbed areas are first colonized by pioneer species, whose presence modifies the site in a way that increases the suitability for other species. One established these later-successional species eventually eliminate the early successional species. Classification of early versus late successional species can be further delineated using species-specific life history traits that align with the facilitative succession path. Early successional species are characterized with rapid colonizing rates, rapid uptake of resources, high-energy requirement, and a low competitive ability for resources. Late successional species are characteristic of limited dispersal, more efficient use of resources, lower energy requirements, and a higher competitive ability for resources (Bazzaz 1979, Tilman and Wedin 1991). Seed dispersal is less important in the successional sequence since because seagrasses are extremely successful in occupying new space via clonal expansion, which is their dominant form of growth. Sexual reproduction via propagule dispersal is less common for seagrasses, but areas distant from surviving seagrass can also be initially established by large slow-growing species that are more effective at seed dispersal (Olesen et al. 2004).

Existing succession models for seagrass 
Repeatable species replacement patterns that follow this seagrass succession model has been observed for the subtidal Caribbean region, where only three dominant species are found. Halodule wrightii (shoal grass) and/or Syringodium filiforme (manatee grass) are considered to be early successional because they posses superior dispersal ability and are found in areas of greater depth, less light, relatively higher nutrient availability, and greater disturbance (Williams 1990). Rapid rhizome growth and branching rates of the pioneer species are accompanied by reduced clonal integration (Fourqurean et al. 1995), higher shoot mortality and lower life expectancy (Gallegos et al. 1994), demonstrating a trade-off in attributes. Thalassia testudinum (turtle grass) is considered to be a late successional species because it has been found to competitively dominant in areas of high light, low nutrients, and stable salinity. As such, the typical succession of Caribbean seagrass into a bare area is calcareous green algae and H.wrightii or S. filiforme followed by $T$. testudinum. This primarily follows the facilitation model of succession; $T$. testudinum benefits from soil modification by the earlier colonizers and eventually replaces the original species. However, T. testudinum is also able to colonize bare sediment in the absence of early colonizers. This suggests that the tolerance succession model may also apply, where all species are capable of establishing a newly disturbed site and biological interactions influence which species persists. This Caribbean model has been developed based on the propensity for T. testudinum to dominate macrophyte communities in the Caribbean (den Hartog 1971) and supported by studies that monitored recolonization patterns after natural disturbances (Patriquin 1975), as well as those that 
experimentally remove vegetation (Williams 1987, Williams 1990, Kenworthy et al. 2002).

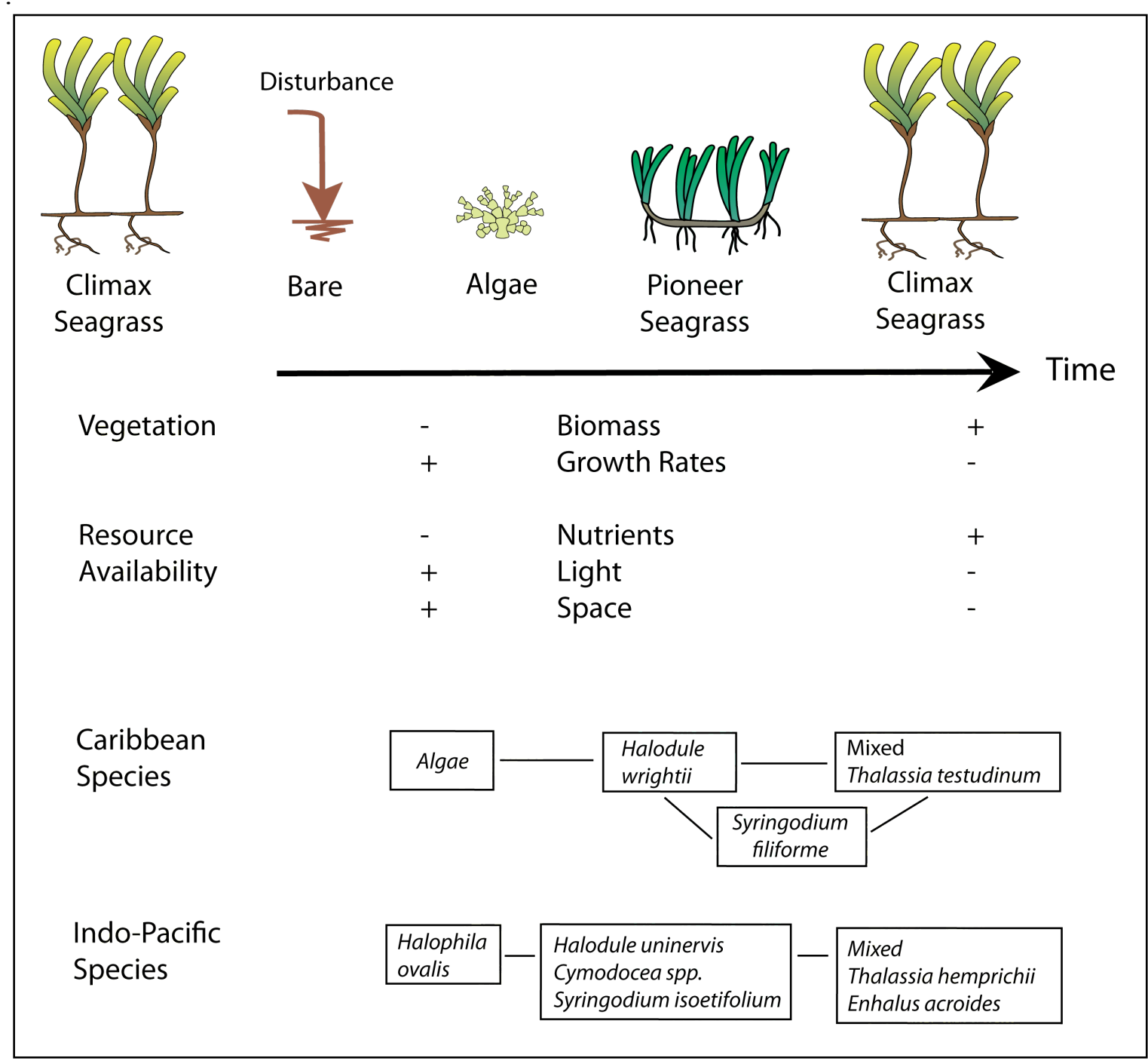

Figure 1.1. Comparison of reported succession patterns (species replacement over time) for subtidal Caribbean and Indo-Pacific Species following a disturbance. 
Seagrass Community Succession within Intertidal Zones of the Indo-West Pacific Successional patterns in the subtidal Indo-Pacific are not as well understood as the Caribbean, in large part because of the higher species diversity that can lead to different recovery trajectories and because less research effort has been dedicated to this region. However, observations of recovery following natural disturbances shows a similar mechanism as the Caribbean, where smaller fast-growing species act as pioneer species (e.g. Halodule uninervis) and are replaced over time by larger slower-growing species (e.g. Thalassia hemprichii)(Birch and Birch 1984, Larkum and West 1990)(Figure 1.1).

Applying a one-size-fits-all succession classification scheme to intertidal Indo-Pacific species becomes more complicated due to varying degrees of environmental stressors found in the intertidal zone. For example, high stress levels in the upper intertidal zone limits the number of potential seagrass colonizers based on their tolerance to air exposure. Experimental and observational studies have demonstrated species-specific responses to disturbance regimes in the intertidal Indo-Pacific (Rollon et al. 1998, Rasheed 1999). These responses can be generalized by grouping individual species into functional groups based upon their relative size, location along the tidal gradient, and colonization potential (Figure 1.2). Successional stages of seagrasses in East Africa can be broadly classified based on their functional group and dominant ecological niche: intertidal pioneer (Halodule spp., Halophila ovalis), intertidal climax (Thalassia hemprichii), subtidal pioneer (Syringodium isotifolium, Cymodocea rotundata) and subtidal climax (Thalassodenron ciliatum, Cymodocea serrulata). 


\begin{tabular}{|c|c|c|c|c|}
\hline pe & FUNCTIONAL GROUP & SPECIES & VEGETATIVE GROWTH & SEXUAL REPRODUCTION \\
\hline 8 & & Halodule univeris & Rapid colonizer & Common \\
\hline Dit & & Nanozostera capensis & Rapid / moderate & Poorly recorded \\
\hline & Mid-intertidal/subtidal & Cymodocean rotundata & Rapid colonizer & Occassional \\
\hline If & & Thalassia hemprichii & Moderate & Occassional \\
\hline H & Low intertidal/subtidal & Syringodium isoetifolium & Moderate & Occasional \\
\hline y & & Cymodocea serrulata & Moderate & Occasional \\
\hline 4 & & Thalassodendron ciliatum & Slower & Poorly recorded \\
\hline
\end{tabular}

Figure 1.2. Relative colonization potential of seagrass species in East Africa. Species are listed in order of relative size, where the top species are smaller and have higher clonal growth rates.

Recovery Following Sediment Burial and Removal Disturbances in the Intertidal Zone Although the size and timing of a disturbance may have the largest effect on the spatial extent of disturbed areas, the mode and intensity of disturbance will likely have the greatest impact on the recovery trajectory. Mode refers to the physical mechanism and corresponding alteration by the disturbance. Two common modes of disturbance that alter seagrass systems are sediment burial or removal. Burial of seagrass plants by sediment occurs with storms, floods and animal burrowing activity. These actions deposit sand on the meadows, reducing light availability and smothering organisms. Larger storms increase erosion and burial depth, causing a decrease in shoot and seed survivorship (Marba \& Duarte 1994, Preen et al. 1995), although some species are able to increase vertical and horizontal growth with burial(Marba et al. 1994, Marba and Duarte 1995, 
Duarte et al. 1997). In contrast to burial, the excavation and removal of sediment causes direct physical damage by uprooting both above- and below-ground vegetation and creating bare patches and holes. Excavation may be caused by burrowing animals, prop and anchor scars, dredging, local harvesting practices, wave action, and storm events. The loss of rhizomes is more damaging than the loss of the living shoots because it effects translocation and apical growth (Terrados et al. 1997). These removal practices can also increase turbidity and alter sediment characteristics by decreasing the sediment binding capacity of the benthos. Micro-scale changes in sediment depth created by sediment burial and removal in the intertidal zone can often be sufficient enough to alter the physical environment and, subsequently, those seagrass species that are able to survive. For example, sediment burial in the upper intertidal may prevent any seagrass colonization because the length of air exposure time is beyond the plant's tolerance levels (Figure 1.3).

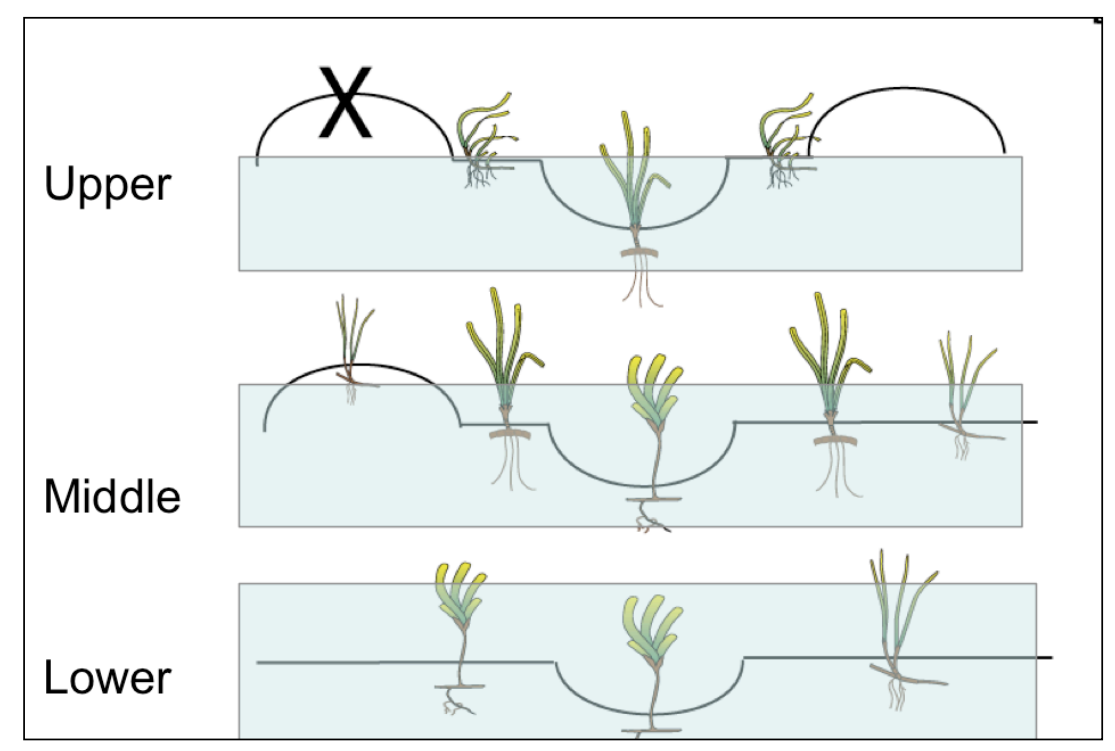


Figure 1.3. Theoretical seagrass distribution integrating intertidal placement and type of disturbance (sediment burial or removal).

The shaded blue area represents standing water at low tide. Smaller species dominate those areas that are characterized by signifiant air exposure for the seagrass shoots, while larger species occupy areas that have minimal air exposure.

Recovery patterns following disturbance will vary depending on the persistence of the physical alteration. This is especially true for intertidal zones, where even slight changes in water depth may either inhibit or facilitate the survivorship of a certain species. For example, burial events in the upper intertidal zone may prevent the re-establishment of seagrass because it exceeds the exposure threshold of the plants. If the sediment is gradually eroded with wave or wind energy then re-colonization may occur. Theoretical recovery patterns following burial or excavation are outlined in Figure 1.4. 


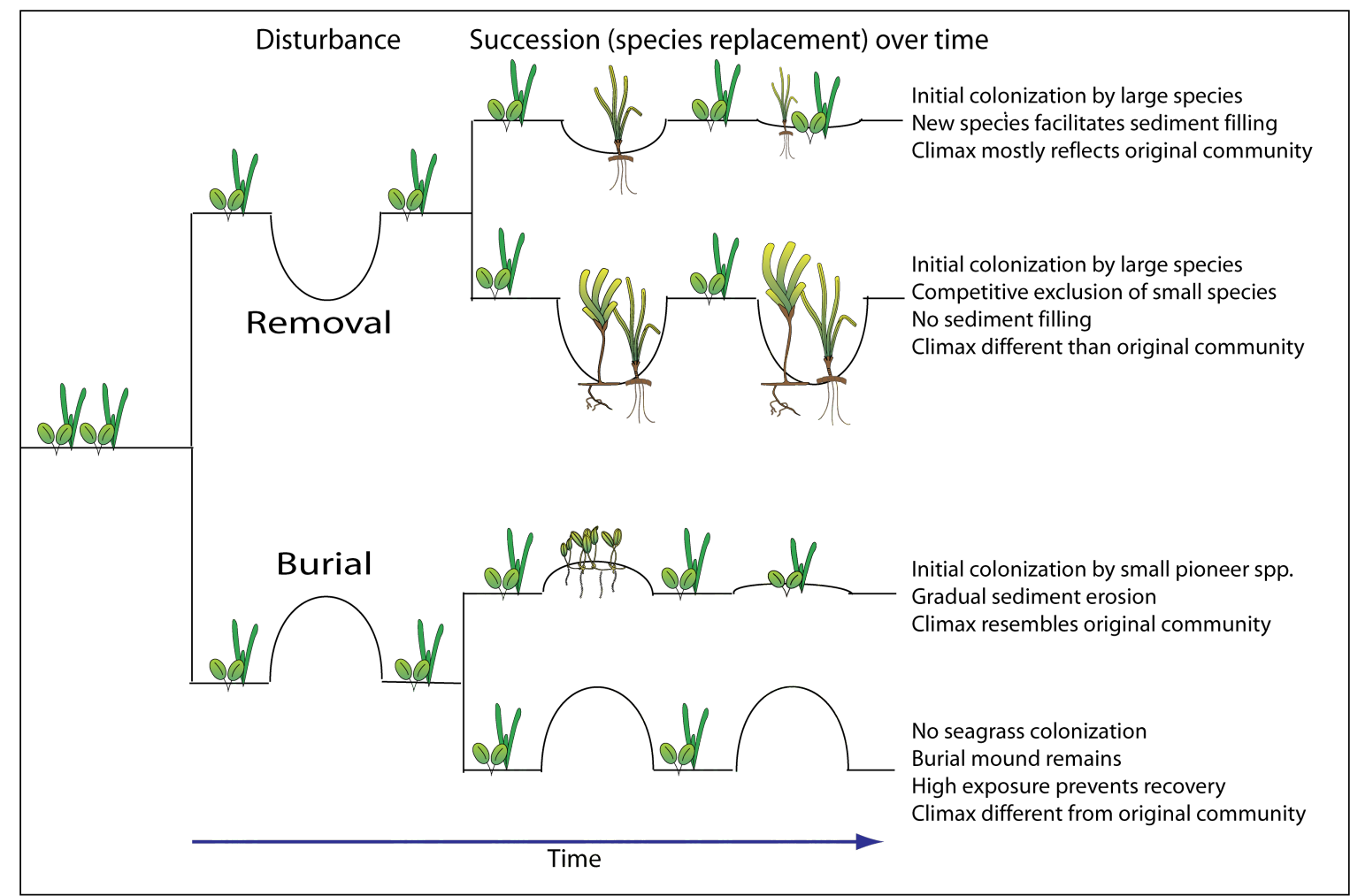

Figure 1.4. Theoretical succession sequences of intertidal seagrass following burial or excavation.

\section{Implications of Disturbance Regime for Seagrasses}

The pattern and rate of recovery for each disturbance varies strongly, from months to decades, even if within the same location (Eckrich and Holmquist 2000). The disturbance intensity also greatly affects species response and community recovery. Seagrass morphology and tolerance to disturbance varies between species, where small sized species with less anchorage structure are more prone to removal during a storm compared to larger species (Bouchon et al. 1991, Fourqurean and Rutten 2004). If the disturbance is too great, future colonization may be inhibited. Disturbances with high hydrodynamic activity such as storms may also enhance dispersal (Kendall et al. 2004). 
Concomitant with the physical alteration of sediment are modifications in the physiochemical properties of the sediment. Changes in sediment grain size and porosity (Erftemeijer and Middelburg 1993), organic and nutrient content (Fourqurean et al. 1992), $\mathrm{pH}$ and redox (Terrados et al. 1999) and sulfide toxicity (Carlson et al. 1994) have been shown to affect seagrass growth and distribution, and may in turn inhibit or facilitate the recolonization of seagrass species. For example, the lack of Thalassia testudinum recovery into propeller scars after 3-5 years may have been related to increased sediment grain size and reduced $\mathrm{pH}$ and redox potential compared to the surrounding patch (Zieman 1976).

Seagrass recolonization patterns may further differ following small versus large disturbances. Disturbances vary considerably in size, from relatively small anchor scars less than a meter wide, to vessel groundings containing depressions several meters deep and extending up to thousands of square meters (Whitfield et al. 2002). Small-scale disturbances create new bare patches that are colonized rapidly by the surviving adjacent vegetation. Large-scale disturbances that remove extensive beds will rely upon dislodged viable shoots (Harwell and Orth 2002) or seedling dispersal (Whitfield et al. 2004), in addition to clonal growth, for full recovery. Such newly-formed seagrass patches are highly dynamic and often self-accelerating such that patch growth may increase with patch size and age (Sintes et al. 2005). 


\section{Landscape Dynamics: Role of disturbance on seagrass heterogeneity and diversity}

Gaps and patches have been defined several different ways in ecological studies. The most common usage of the term 'gap' originates in forest communities, where the death of an individual canopy plant frees up open space and resources for other species to invade. A classic example is tree falls that results in openings in the forest canopy (Watt 1947). Any definition of a gap that is restricted to individual species mortality is irrelevant for seagrass communities because seagrass plants are clonal. However, the underlying mechanism of how the disturbance affects spatial heterogeneity and community structure is the same. The loss of seagrass canopy following disturbance also creates openings within the vegetated environment that is analogous to that of light gaps created by tree falls in forests (Oldeman 1978), lightning strikes in mangroves (Sherman et al. 2000), or badger mounds in grasslands (Platt 1975). When a bare patch is created by the disturbance, resources such as light and space are made available for new species recruitment. Regular disturbance activity leads to a shifting mosaic of patches across the landscape, each at different stages of recovery (Watt 1947, Pickett and White 1985). With respect to this dissertation, terminology of gap versus patch will follow the prevailing usage in seagrass literature; patches represent any relatively discrete spatial pattern containing vegetation that differs from the surrounding vegetation, whereas gaps are patches of un-vegetated substrate within a vegetated patch of seagrass that was created by disturbances within a patch of vegetation (Bell et al. 2006). 


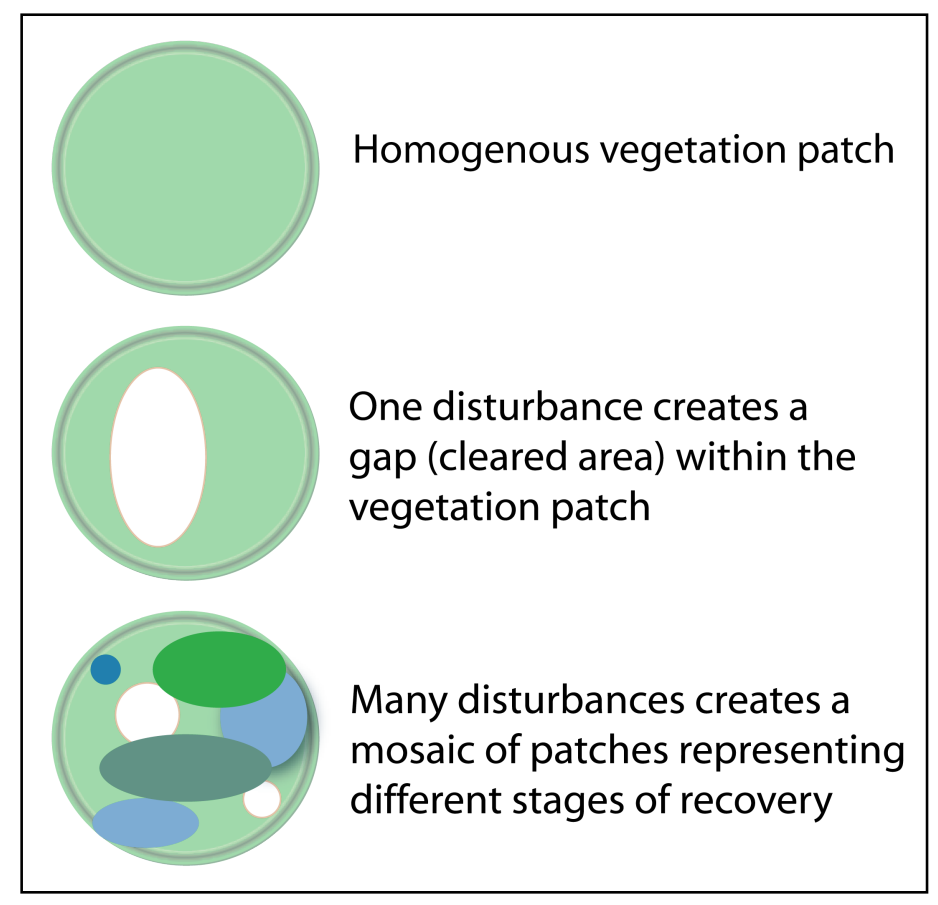

Figure 1.5. Illustration of how the size and number of disturbances affect landscape heterogeneity in seagrass meadows.

As in terrestrial and other marine communities, disturbances create gaps in the seagrass canopy through damage to plant biomass or mortality of shoots. This can lead to different sizes of patches across the landscape (Figure 1.5). Each patch will be undergoing a different phase in species replacement following a disturbance, which creates a mosaic of patches with different geometry and species composition. For example, one large storm event in a subtidal homogenous bed will result in a single large gap, or many small disturbances (e.g. boat scars) will result in many small gaps and seagrass patches with distinct species assemblages. The arrangement of patches may influences numerous aspects of seagrass structure and ecological processes including population growth (Vidondo et al. 1997, Kendrick et al. 2005), patch persistence (Bell et al. 1999), 
hydrodynamic flow (Fonseca and Koehl 2006), and associated faunal composition and migration (Bell et al. 2001) (Healey and Hovel 2004). The role of patchiness in maintaining heterogeneity and biodiversity is not well understood for these relatively species-poor seagrass systems. The study of seagrass processes and dynamics from a landscape ecology perspective is a relatively recent trend (Bell et al. 1999, Robbins and Bell 2000, Fonseca et al. 2002, Hovel et al. 2002, Bostrom et al. 2006). These studies have emphasized how the shape and distribution of patches change over time, what factors influence these changes (i.e., hydrodynamic regime) and how patch distribution affects other ecosystem properties (i.e., faunal activity). In contrast to the limited studies on seagrass landscape ecology, a plethora of studies have examined aspects of smallscale disturbances in seagrass habitats (Zieman 1976, Williams 1988, Marba and Duarte 1994, Duarte et al. 1997, Holmquist 1997, Rollon et al. 1998, Creed and Amado 1999, Rasheed 1999, Ramage and Schiel 1999, Cruz-Palacios and van Tussenbroek 2005). However, none have attempted to link disturbance regime to landscape attributes by linking plant recolonization processes at the local scale with patch dynamics at the landscape scale.

A common theme within seagrass studies is that disturbance acts as a force that leads to seagrass decline or loss. Rarely is disturbance treated as a natural phenomenon that may help perpetuate species co-existence and diversity. Although a given disturbance regime may help maintain regional diversity by creating a mosaic of patches and new space for colonization, this is not always the case (Sousa 2001, Fourqurean and Rutten 2004). 
Intermediate levels of natural disturbance have been cited as maintaining high biodiversity in species-rich ecosystems such as coral reefs and tropical rainforests (Connell 1978), but these theories have not been explored for seagrass systems. There is very little data to support the importance of disturbance as a driver of aspects of seagrass community structure such as diversity, even though it is considered to be an important driver in other systems

\section{Dissertation Objectives and Questions}

Understanding how disturbance affects seagrass ecosystems requires studies on both the initial response and subsequent recovery at different scales - from plant-specific processes to changes in the landscape matrix. The overall theme of this proposed research is to investigate the response of mixed-species intertidal seagrass communities to disturbance, and the recovery to these disturbances at the population, community and landscape level. This will be approached using a variety of methods ranging from the plant-level to the landscape-scale and includes the use of field surveys, monitoring, in situ experiments, and remote sensing. The ultimate goal of this work is to identify relationships between disturbances and seagrasses at the plant and landscape scale within intertidal zones (Figure 1.6). 


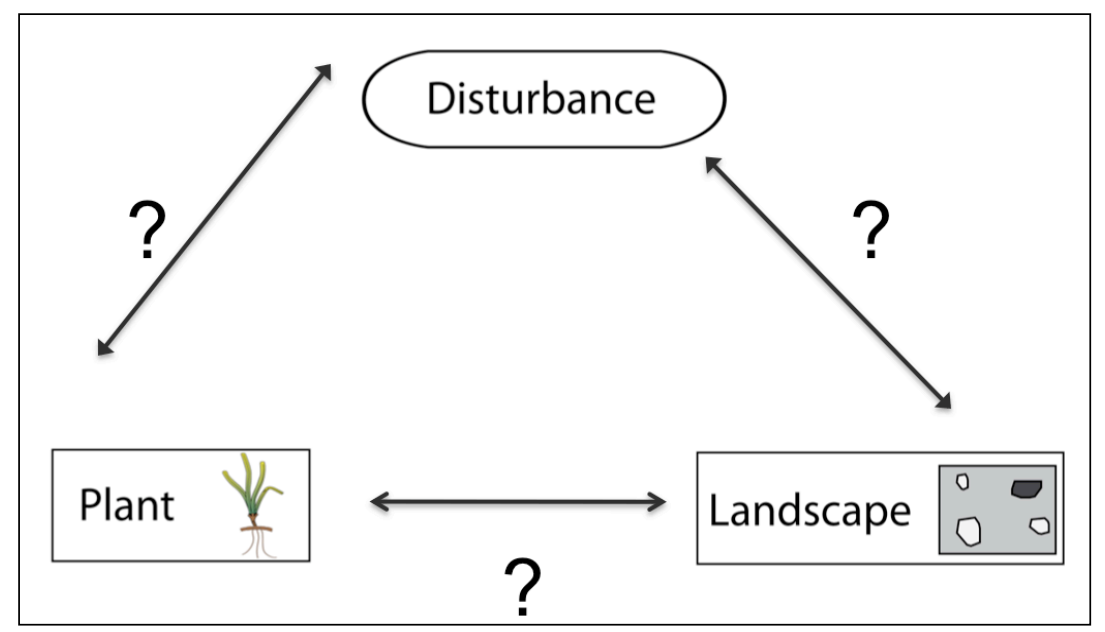

Figure 1.6. Incomplete conceptual model describing relationships between disturbance and seagrasses at the plant and landscape scale.

Specific questions regarding seagrass and disturbance that are addressed in this study fall under the following four general themes and are presented below.

1. Plant and Landscape Patterns

a. What seagrass zonation patterns exist across the intertidal zone? (Chapter 2)

b. What disturbance patterns exist across the intertidal zone? (Chapter 2)

c. Is there a correlative relationship between disturbance and seagrass species diversity? (Chapter 2)

2. Plant Dynamics

a. What is the recovery trajectory (rate and direction) of seagrasses and animals following experimental disturbances across the intertidal zone? (Chapter 3)

b. How does the recovery trajectory vary based on disturbance type - burial or excavation? (Chapter 3) 
c. Does this experimental disturbance produce the same predicted results of seagrass species diversity that were identified in Chapter 2? If so, what is the mechanism? (Chapter 3)

d. Does sediment organic content affect seagrass recovery? (Chapter 4)

3. Landscape Dynamics

a. How do gaps that are created by disturbances within seagrass meadows change over a two-year period? (Chapter 5)

b. Does gap change over time differ along an intertidal gradient? (Chapter 5)

4. Linking Plant and Landscape Processes

a. Are gap recovery rates found at plant-level studies the same as those observed at landscape scales? (Chapter 3 and 5)

\section{Dissertation Outline}

To address these objectives and questions above, this dissertation is divided into the following six chapters.

Chapter One: Introduction. This chapter provides a brief background of the general ecological concepts addressed in this dissertation with respect to seagrass ecosystems.

Chapter Two: Factors regulating seagrass species diversity and co-existence across an intertidal landscape. This chapter uses extensive field surveys to describe species 
diversity patterns across an intertidal gradient, and to examine factors that may be influencing these patterns.

Chapter Three: Disturbance type and tidal placement affect recovery patterns of marine plant communities. This chapter builds upon the survey data in Chapter 2 by using a 20-month field experiment that replicates natural disturbance regimes. This experiment explicitly examines whether disturbance type (sediment burial, sediment removal) and location (upper, middle, lower intertidal) affect recovery rates and trajectories for sediment, flora, and fauna components.

Chapter Four: Seagrass recovery following experimental changes in sediment organic content. This chapter uses a one-year field experiment to determine if sediment organic content in recently-disturbed gaps will affect seagrass recovery.

Chapter Five: Seagrass gap dynamics across an Indo-Pacific intertidal landscape. This chapter uses high-resoultion satellite imagery to identify gap distribution across the intertidal zone, and determine how these gaps change over a two year time period.

Chapter Six: Synthesis and Conclusions. This chapter includes a general discussion and synthesis of results, returns to the questions put forth earlier in this chapter, and begins to connect plant-scale processes with landscape-scale patterns and proposes ideas for further research to build upon these results. 


\section{Significance of this study}

This dissertation is aimed at building upon the limited scientific basis related to seagrass disturbance and recovery, while addressing specific deficiencies in our understanding of seagrass ecology.

\section{Seagrass habitats with high species diversity}

The majority of research conducted in seagrass systems has focused on areas with relatively low plant species diversity, such as the temperate Atlantic, the Caribbean and the Mediterranean. Globally, seagrass species diversity is highest in the tropical and subtropical waters of the Indo-Pacific, including East Africa. The extensive seagrass beds found along the $2700 \mathrm{~km}$ Mozambican coastline contain some of the highest species diversity in the world and are relatively un-impacted by human activity. Mozambique has 11 species of seagrasses, following only Western Australia in regional species richness (Bandeira, 2002). Our general understanding of the biology and ecology of Indo-West Pacific species is limited. Also, the role of disturbance in maintaining heterogeneity and biodiversity is not well understood for seagrass systems, particularly in species-rich locales. This dissertation examines the role of disturbance on species diversity in Mozambique (Chapter 2, 3). 


\section{Intertidal habitats}

Seagrass research is also skewed toward subtidal systems, although intertidal seagrass habitats are quite common especially in the Indo-West Pacific. Environmental factors unique to the intertidal zone, such as increased exposure and hydrodynamic impacts, may limit some of our understanding of disturbance and recovery dynamics that has evolved primarily from studies of subtidal systems. This dissertation focus on intertidal seagrass communities, and strives to illustrate the similarities to, and differences from, subtidal habitats (Chapter 2, 3, 4, 5)

\section{Small-scale disturbances}

Naturally occurring small-scale disturbances are often neglected in studies of gap dynamics based on the assumption that such small changes do not contribute significantly to the overall spatial complexity of a landscape (Bell et al., 1999). However, a few have alluded that their presence deserves further investigation (Duarte et al., 1997). This is the first effort to quantify small-scale gap dynamics (Chapter 2, 5).

\section{Habitat preservation and restoration}

With a reported global decline in seagrass habitat attributed to a growing number of stressors, (Orth et al., 2006), and growing acknowledgement of the importance of these systems to critical ecosystem processes, more attention is being placed on restoring lost seagrass or minimizing the loss of existing habitats. This dissertation will provide 
guidance to resource management plans including restoration efforts and in deciding what areas are most resilient to disturbances such as dredging (Chapter 3, 4).

\section{Human applications}

Seagrass research on small-scale disturbances has focused almost exclusively on seagrass-specific responses. However, the direct dependence of local human populations on fauna (e.g. fish, bivalves, crabs) residing within seagrass systems for food security and income highlights the need to understand properties beyond the plant level. This dissertation is the first to examine the effects of different types of disturbance on the faunal component (Chapter 3).

\section{References}

Alcoverro, T. and S. Mariani. 2002. Effects of sea urchin grazing on seagrass (Thalassodendron ciliatum) beds of a Kenyan lagoon. Marine Ecology Progress Series 226: 255-263.

Bazzaz, F. A., 1979. Physiological ecology of plant succession. Annual Review of Ecology and Systematics 10: 351-371.

Beck, M. W., K. L. Heck, K. W. Able, D. L. Childers, D. B. Eggleston, B. M. Gillanders, B. Halpern, C. G. Hays, K. Hoshino, T. J. Minello, R. J. Orth, P. F. Sheridan, and M. R. Weinstein. 2001. The identification, conservation, and management of estuarine and marine nurseries for fish and invertebrates. Bioscience 51: 633-641.

Bell, S. S., B. D. Robbins, and S. L. Jensen. 1999. Gap dynamics in a seagrass landscape. Ecosystems 2: 493-504.

Bell, S. S., M. S. Fonseca, and N. B. Stafford. 2006. Seagrass ecology: New contributions from a landscape perspective, pp. 625-645 in Seagrasses: Biology, Ecology and Conservation, edited by A. W. D. Larkum, R. J. Orth and C. M. Duarte. Springer.

Bell, S. S., R. A. Brooks, B. D. Robbins, M. S. Fonseca, and M. O. Hall. 2001. Faunal response to fragmentation in seagrass habitats: implications for seagrass conservation. Biological Conservation 100: 115-123. 
Birch, W. R. and M. Birch. 1984. Succession and pattern of tropical intertidal seagrasses in Cockle Bay, Queensland, Australia: A decade of observations. Aquatic Botany 19: 343-367.

Bostrom, C., E. L. Jackson, and C. A. Simenstad. 2006. Seagrass landscapes and their effects on associated fauna: A review. Estuarine Coastal Shelf Science 68: 383403.

Bouchon, C., Y. Bouchon-Navaro, D. Imbert, and M. Louis. 1991. The effect of Hurricane Hugo on the coastal environment of Guadeloupe Island(FWI). Annales de l'Institut oceanographique, Paris. 67: 5-33.

Carlson, P. R., L. A. Yarbro, and T. R. Barber. 1994. Relationship of sediment sulfide to mortality of Thalassia testudinum in Florida Bay. Bulletin of Marine Science 54: 733-746.

Carruthers, T. J. B., W. C. Dennison, B. J. Longstaff, M. Waycott, E. G. Abal, L. J. McKenzie, and W. J. L. Long. 2002. Seagrass habitats of northeast Australia: Models of key processes and controls. Bulletin of Marine Science 71: 1153-1169.

Clements, F. E., 1916. Plant succession: Analysis of the development of vegetation. Carnegie Inst. Wash. Publ. 1-512.

Connell, J. H., 1972. Community interactions on marine rocky intertidal shores. Annual Review of Ecology and Systematics 169-192 .

Connell, J. H., 1978. Diversity of tropical rain forests and coral reefs. Science 199: 13021310.

Creed, J. C. and G. M. Amado. 1999. Disturbance and recovery of the macroflora of a seagrass (Halodule wrightii Ascherson) meadow in the Abrolhos Marine National Park, Brazil: an experimental evaluation of anchor damage. Journal of Experimental Marine Biology and Ecology 235: 285-306.

Cruz-Palacios, V. and B. I. van Tussenbroek. 2005. Simulation of hurricane-like disturbances on a Caribbean seagrass bed. Journal of Experimental Marine Biology and Ecology 324: 44-60.

Dayton, P. K., 1971. Competition, disturbance, and community organization: the provision and subsequent utilization of space in a rocky intertidal community. Ecological Monographs 41: 351-389.

den Hartog, C. and J. Kuo. 2006. Taxonomy and biogeography of seagrasses, pp. 1-23 in Seagrasses: Biology, Ecology and Conservation, edited by A. W. D. Larkum, R. J. Orth and C. M. Duarte. Springer.

den Hartog, C., 1971. The dynamic aspect in the ecology of seagrass communities. Thalassia Testudinum Jugoslavica 101-112.

Dennison, W. C., 1987. Effects of light on seagrass photsynthesis, growth and depth distribution. Aquatic Botany 27: 15-26.

Duarte, C. M. and C. L. Chiscano. 1999. Seagrass biomass and production: A reassessment. Aquatic Botany 159-174.

Duarte, C. M., J. Terrados, N. S. R. Agawin, M. D. Fortes, S. Bach, and W. J. Kenworthy. 1997. Response of a mixed Philippine seagrass meadow to experimental burial. Marine Ecology Progress Series 147: 285-294. 
Eckrich, C. E. and J. G. Holmquist. 2000. Trampling in a seagrass assemblage: direct effects, response of associated fauna, and the role of substrate characteristics. Marine Ecology Progress Series 201: 199-209.

Erftemeijer, P. L. A. and J. J. Middelburg. 1993. Sediment-nutrient interactions in tropical seagrass beds: a comparison between a terrigenous and a carbonate sedimentary environment in South Sulawesi (Indonesia). Marine Ecology Progress Series 102: 187-198.

Erftemeijer, P. L. A. and R. R. R. Lewis. 2006. Environmental impacts of dredging on seagrasses: A review. Marine Pollution Bulletin 52: 1553-1572.

Ferdie, M. and J. W. Fourqurean. 2004. Responses of seagrass communities to fertilization along a gradient of relative availability of nitrogen and phosphorus in a carbonate environment. Limnology and Oceanography 49: 2082-2094.

Fonseca, M. S. and M. A. R. Koehl. 2006. Flow in seagrass canopies: The influence of patch width. Estuarine Coastal Shelf Science 67: 1-9.

Fonseca, M. S., P. E. Whitfield, W. J. Kenworthy, D. R. Colby, and B. E. Julius. 2004. Use of two spatially explicit models to determine the effect of injury geometry on natural resource recovery. Aquatic Conservation 14: 281-298.

Fonseca, M., P. E. Whitfield, N. M. Kelly, and S. S. Bell. 2002. Modeling seagrass landscape pattern and associated ecological attributes. Ecological Applications 12: 218-237.

Fourqurean, J. W. and L. M. Rutten. 2004. The impact of Hurricane Georges on softbottom, back reef communities: Site- and species-specific effects in south Florida seagrass beds. Bulletin of Marine Science 75: 239-257.

Fourqurean, J. W., G. V. N. Powell, W. J. Kenworthy, and J. C. Zieman. 1995. The effects of long-term manipulation of nutrient supply on competition between the seasgrasses Thalassia testudinum and Halodule wrightii in Florida Bay. OIKOS 72: 349-358.

Fourqurean, J. W., J. C. Zieman, and G. V. N. Powell. 1992. Relationships between porewater nutrients and seagrasses in a subtropical carbonate environment. Marine Biology 114: 57-65.

Gallegos, M. E., M. Merino, A. Rodriquez, N. Marba, and C. M. Duarte. 1994. Growthpatterns and demography of pioneer Caribbean seagrasses Halodule wrightii and Syringodium filiforme. Marine Ecology Progress Series 109: 99-104.

Gleason, H. A., 1917. The structure and development of the plant association. Bulletin of the Torrey Botanical Club 43: 463-481.

Grime, J. P., 1977. Evidence for the existence of three primary strategies in plants and its relevance to ecological and evolutionary theory. American Naturalist 1169-1194.

Harwell, M. C. and R. J. Orth. 2002. Long-distance dispersal potential in a marine macrophyte. Ecology 83: 3319-3330.

Hay, M. E., 1997. The ecology and evolution of seaweed-herbivore interactions on coral reefs. Coral Reefs 16: 67-76.

Healey, D. and K. A. Hovel. 2004. Seagrass bed patchiness: effects on epifaunal communities in San Diego Bay, USA. Journal of Experimental Marine Biology and Ecology 313: 155-174. 
Heck, K. L., J. R. Pennock, J. F. Valentine, L. D. Coen, and S. A. Sklenar. 2000. Effects of nutrient enrichment and small predator density on seagrass ecosystems: An experimental assessment. Limnology and Oceanography 45: 1041-1057.

Heck, K. L., T. J. B. Carruthers, C. M. Duarte, A. R. Hughes, G. Kendrick, R. J. Orth, and S. W. Williams. 2008. Trophic Transfers from Seagrass Meadows Subsidize Diverse Marine and Terrestrial Consumers. Ecosystems 11: 1198-1210.

Hemminga, M. and C. Duarte. 2000. Seagrass ecology: an introduction. Cambridge University Press, New York, NY, USA.

Holmquist, J. G., 1997. Disturbance and gap formation in a marine benthic mosaic: influence of shifting macroalgal patches on seagrass structure and mobile invertebrates. Marine Ecology Progress Series 158: 121-130.

Hovel, K. A., M. S. Fonseca, D. L. Myer, W. J. Kenworthy, and P. E. Whitfield. 2002. Effects of seagrass landscape structure, structural complexity and hydrodynamic regime on macrofaunal densities in North Carolina seagrass beds. Marine Ecology Progress Series 243: 11-24.

Johnson, E. A. and K. Miyanishi. 2007. Plant Disturbance Ecology: The Process and the Response. Elsevier .

Kendall, M. S., T. Battista, and Z. Hillis-Starr. 2004. Long term expansion of a deep Syringodium filiforme meadow in St. Croix, US Virgin Islands: the potential role of hurricanes in the dispersal of seeds. Aquatic Botany 78: 15-25.

Kendrick, G. A., C. M. Duarte, and N. Marba. 2005. Clonality in seagrasses, emergent properties and seagrass landscapes. Marine Ecology Progress Series 290: 291296.

Kenworthy, W. J., M. S. Fonseca, P. E. Whitfield, and K. K. Hammerstrom. 2002. Analysis of seagrass recovery in experimental excavations and propeller-scar disturbances in the Florida Keys National Marine Sanctuary. Journal of Coastal Research 75-85.

Kirkman, H. and J. Kuo. 1990. Pattern and process in Southern Western Australian seagrasses. Aquatic Botany 37: 367-382.

Kirsch, K. D., K. A. Barry, M. S. Fonseca, P. E. Whitfield, S. R. Meehan, W. J. Kenworthy, and B. E. Julius. 2005. The mini-312 program - An expedited damage assessment and restoration process for seagrasses in the Florida Keys National Marine Sanctuary. Journal of Coastal Research 109-119.

Larkum, A. W. D. and R. J. West. 1990. Long-term changes of seagrass meadows in Botany Bay, Australia. Aquatic Botany 37: 55-70.

Larned, S. T., 2003. Effects of the invasive, nonindigenous seagrass Zostera japonica on nutrient fluxes between the water column and benthos in a NE Pacific estuary. Marine Ecology Progress Series 254: 69-80.

Lee, K. S. and K. H. Dunton. 2000. Effects of nitrogen enrichment on biomass allocation, growth, and leaf morphology of the seagrass Thalassia testudinum. Marine Ecology Progress Series 196: 39-48.

Lewis, J. R., 1964. The ecology of rocky shores, 323 pp. London: English University Press. 
Livingston, R. J., S. E. McGlynn, and X. F. Niu. 1998. Factors controlling seagrass growth in a gulf coastal system: Water and sediment quality and light. Aquatic Botany 60: 135-159.

Marba, N. and C. M. Duarte. 1994. Growth response of the seagrass Cymodocea Nodosa to experimental burial and erosion. Marine Ecology Progress Series 107: 307-311.

Marba, N. and C. M. Duarte. 1995. Coupling of seagrass (Cymodocea nodosa) patch dynamics to subaqueous dune migration. Journal of Ecology 83: 381-389.

Marba, N., M. E. Gallegos, M. Merino, and C. M. Duarte. 1994. Vertical growth of Thalassia testudinum: Seasonal and interannual variability. Aquatic Botany 47: 111.

Marbà, N., M. Holmer, E. Gacia, and C. Barron. 2006. Seagrass Beds and Coastal Biogeochemistry, pp. 135-157 in Seagrasses: Biology, Ecology and Conservation. Springer.

McGlathery, K. J., 1995. Nutrient and grazing influences on a subtropical seagrass community. Marine Ecology Progress Series 122: 239-252.

McRoy, C. P. and C. McMillan. 1977. Production and physiology of seagrasses, pp. 5388 in Seagrass ecosystems: A scientific perspective. Marcel Dekker, New York.

Oldeman, R. A. A., 1978. Architecture and energy exchange of dicotyledonous trees in the forest. Tropical Trees as Living Systems. Cambridge University Press, Cambridge.

Olesen, B., N. Marba, C. M. Duarte, R. S. Savela, and M. D. Fortes. 2004. Recolonization dynamics in a mixed seagrass meadow: The role of clonal versus sexual processes. Estuaries 27: 770-780.

Orth, R. J., T. J. B. Carruthers, W. C. Dennison, C. M. Duarte, J. W. Fourqurean, K. L. Heck, A. R. Hughes, G. A. Kendrick, W. J. Kenworthy, S. Olyarnik, F. T. Short, M. Waycott, and S. L. Williams. 2006. A global crisis for seagrass ecosystems. Bioscience 56: 987-996.

Patriquin, D. G., 1975. "Migration" of blowouts in seagrass beds at Barbados and Carriacou, West Indies, and its ecological and geological implications. Aquatic Botany 163-189.

Pickett, S. T. A. and B. White. 1985. The ecology of natural disturbances and patch dynamics. Academic Press, Orlando, FL.

Platt, W. J., 1975. The colonization and formation of equilibrium plant species associations on badger disturbances in a tall-grass prairie. Ecological Monographs 285-305.

Preen, A. R., W. J. L. Long, and R. G. Coles. 1995. Flood and cyclone related loss, and partial recovery, of more than $1000 \mathrm{~km}^{2}$ of seagrass in Hervey Bay, Queensland, Australia. Aquatic Botany 52: -17 .

Ramage, D. L. and D. R. Schiel. 1999. Patch dynamics and response to disturbance of the seagrass Zostera novazelandica on intertidal platforms in southern New Zealand. Marine Ecology Progress Series 189: 275-288.

Rasheed, M. A., 1999. Recovery of experimentally created gaps within a tropical Zostera capricorni (Aschers.) seagrass meadow, Queensland Australia. Journal of Experimental Marine Biology and Ecology 235: 183-200. 
Robbins, B. D. and S. S. Bell. 2000. Dynamics of a subtidal seagrass landscape: Seasonal and annual change in relation to water depth. Ecology 81: 1193-1205.

Rollon, R. N., E. D. D. Van Steveninck, W. Van Vierssen, and M. D. Fortes. 1998. Contrasting recolonization strategies in multi-species seagrass meadows. Marine Pollution Bulletin 37: 450-459.

Rose, C. D., W. C. Sharp, W. J. Kenworthy, J. H. Hunt, W. G. Lyons, E. J. Prager, J. F. Valentine, M. O. Hall, P. E. Whitfield, and J. W. Fourqurean. 1999. Overgrazing of a large seagrass bed by the sea urchin Lytechinus variegatus in Outer Florida Bay. Marine Ecology Progress Series 190: 211-222.

Sherman, R. E., T. J. Fahey, and J. J. Battles. 2000. Small-scale disturbance and regeneration dynamics in a neotropical mangrove forest. Journal of Ecology 88: 165-178.

Short, F. T., 1983. The response of interstitial ammonium in eelgrass (Zostera marina L.) beds to environmental perturbations. Journal of Experimental Marine Biology and Ecology 68: 195-208.

Sintes, T., N. Marba, C. M. Duarte, and G. A. Kendrick. 2005. Nonlinear processes in seagrass colonisation explained by simple clonal growth rules. OIKOS 108: 165175.

Sousa, W. P., 1979. Experimental investigations of disturbance and ecological succession in a rocky intertidal algal community. Ecological Monongraphs 49: 227-254.

Sousa, W. P., 2001. Natural disturbance and the dynamics of marine benthic communities, in Marine Community Ecology, edited by M. D. Bertness, S. D. Gaines and M. E. Hay. Sinauer Associates, Massachusetts.

Suchanek, T. H., 1983. Control of seagrass communities and sediment distribution by Callianassa (Crustacea, Thalassinidea) bioturbation. Journal of Marine Research 41: 281-298.

Terrados, J., C. M. Duarte, and W. J. Kenworthy. 1997. Is the apical growth of Cymodocea nodosa dependent on clonal integration? Marine Ecology Progress Series 158: 103-110.

Terrados, J., C. M. Duarte, L. Kamp-Nielsen, N. S. R. Agawin, E. Gacia, D. Lacap, M. D. Fortes, J. Borum, M. Lubanski, and T. Greve. 1999. Are seagrass growth and survival constrained by the reducing conditions of the sediment? Aquatic Botany 65: $175-197$.

Thrush, S. F. and P. K. Dayton. 2002. Disturbance to marine benthic habitats by trawling and dredging: Implications for marine biodiversity. Annual Review of Ecology and Systematics 33: 449-473.

Tilman, D. and D. Wedin. 1991. Plant traits and resource reduction for 5 grasses growing on a nitrogen gradient. Ecology 72: 685-700.

Townsend, E. C. and M. S. Fonseca. 1998. Bioturbation as a potential mechanism influencing spatial heterogeneity of North Carolina seagrass beds. Marine Ecology Progress Series 169: 123-132.

Valentine, J. F. and K. L. Heck. 1991. The role of sea urchin grazing in regulating subtropical seagrass meadows - Evidence from field manipulations in the northern 
Gulf of Mexico. Journal of Experimental Marine Biology and Ecology 154: 215230.

Valentine, J. F., K. L. Heck, P. Harper, and M. Beck. 1994. Effects of bioturbation in controlling Turtlegrass (Thalassia testudinum Banks Ex Konig), abundance Evidence from field enclosures and observations in the Northern Gulf of Mexico. Journal of Experimental Marine Biology and Ecology 178: 181-192.

Valiela, I., J. McClelland, J. Hauxwell, P. J. Behr, D. Hersh, and K. Foreman. 1997. Macroalgal blooms in shallow estuaries: Controls and ecophysiological and ecosystem consequences. Limnology and Oceanography 42: 1105-1118.

Vidondo, B., C. M. Duarte, A. L. Middelboe, K. Stefansen, T. Lutzen, and S. L. Nielsen. 1997. Dynamics of a landscape mosaic: size and age distributions, growth and demography of seagrass Cymodocea nodosa patches. Marine Ecology Progress Series 158: 131-138.

Watt, A. S., 1947. Pattern and process in the plant community. Journal of Ecology 35: 122.

Waycott, M., C. M. Duarte, T. J. Carruthers, R. J. Orth, W. C. Dennison, S. Olyarnik, A. Calladine, J. W. Fourqurean, K. L. Heck, A. R. Hughes, G. A. Kendrick, W. J. Kenworthy, F. T. Short, and S. L. Williams. 2009. Accelerating loss of seagrasses across the globe threatens coastal ecosystems. Proceedings of the National Academy of the United States of America .

Whitfield, P. E., J. W. Kenworthy, K. K. Hammerstrom, and M. S. Fonseca. 2002. The role of a hurricane in the expansion of disturbances initiated by motor vessels on seagrass banks. Journal of Coastal Research 86-99 .

Whitfield, P. E., W. J. Kenworthy, M. J. Durako, K. K. Hammerstrom, and M. F. Merello. 2004. Recruitment of Thalassia testudinum seedlings into physically disturbed seagrass beds. Marine Ecology Progress Series 267: 121-131.

Williams, S. L., 1987. Competition between the seagrasses Thalassia testudinum and Syringodium filiforme in a Caribbean lagoon. Marine Ecology Progress Series 35: 91-98.

Williams, S. L., 1988. Thalassia testudinum productivity and grazing by green turtles in a highly disturbed seagrass bed. Marine Biology 98: 447-455.

Williams, S. L., 1990. Experimental studies of Caribbean seagrass bed development. Ecological Monographs 60: 449-469.

Zieman, J. C., 1976. The ecological effects of physical damage from motor boats on turtle grass beds in Southern Florida. Aquatic Botany 127-139.

Zieman, J. C., 1985. Nutrient cycling, production, and detrital processing in sub-tropical seagrass systems of the southeastern United States. American Journal of Botany 72: 843-843. 


\title{
Chapter Two: Factors regulating seagrass species diversity and co-existence across an intertidal landscape
}

\begin{abstract}
Factors regulating plant diversity are poorly understood in marine soft-bottom communities. This study examined how both macro-scale factors (tidal gradient) and micro-scale factors (small-scale disturbance) can influence seagrass zonation and species diversity patterns across an intertidal landscape in the Indo-Pacific region. 413 sites were surveyed around Inhaca Island in southern Mozambique, Africa. Eight species of seagrasses were identified and $71 \%$ of the sites had mixed-species meadows, as contrasted with $29 \%$ of seagrass meadows composed of single species. A maximum of seven co-existing species were found in a single meadow. Seagrass zonation was characterized by a shift from smaller species in the shallower upper intertidal zones (i.e. Halodule uninervis) to larger species in the deeper intertidal zones (i.e. Thalassodenron ciliatum). A unimodal pattern of species richness and evenness was observed, with species diversity highest in the middle intertidal (mean $=3.4$ species) compared to the upper (mean=1.78) and lower intertidal (mean=1.9). Reduced diversity in the upper intertidal was attributed to increased air exposure that selects for only a few stressadapted species. Reduced diversity in the lower intertidal may be related to the competitive displacement of smaller-sized plants by larger plants. No significant effect of sediment conditions (organic content, bulk density, porewater redox and $\mathrm{pH}$ ) was found
\end{abstract}


between intertidal zones, or on plant diversity patterns. To determine the role of disturbance on the observed diversity patterns, the number and size of disturbancegenerated gaps at 43 sites were quantified. Disturbance was a common feature in the intertidal seagrass zone, indicated by the predominance of small-sized $\left(>0.25 \mathrm{~m}^{2}\right)$ gaps created by bioturbation and hydrodynamics within the meadows. Disturbance intensity decreased with depth and was highest in the upper intertidal (mean area disturbed $=21.38$ $\%$, mean number of disturbances $=74$ ) and lowest in the lower intertidal (mean area disturbed $=7.00 \%$, mean number of disturbances $=16$ ). This pattern supports disturbance-diversity theories such as the Intermediate Disturbance Hypothesis (IDH) that predicts higher species diversity at moderate levels of disturbance, but the mechanism responsible for this pattern differs from that of the IDH. For the intertidal zone, disturbances that modify sediment depth results in changes of standing water at low tide. These small changes shift the competitive outcome and promote local diversity through new recruitment. This mode of recovery differs from mechanisms described in other models that emphasize a mosaic of different successional stages following a disturbance. A conceptual model of seagrass co-existence is presented for tropical intertidal seagrass zones, which can be used to predict how seagrass communities will respond to specific disturbance regimes along a tidal gradient 


\section{Introduction}

Seagrasses are clonal marine plants that form extensive submerged meadows and occupy shallow coastal areas on all continents except Antarctica. Despite their widespread geographic range and long evolutionary record of over 100 million years, there are only around 60 extant species worldwide (den Hartog and Kuo 2006). Present day large-scale distributions of seagrasses are a product of numerous processes (Waycott et al. 2006) and global diversity patterns mirror terrestrial plants in that diversity increases with decreasing latitude, especially in the Indo-Pacific. Our understanding of the ecological factors regulating seagrass species diversity at local scales is limited because seagrass research has been concentrated in only a few areas of the world that have low species richness; monospecific meadows of temperate Zostera marina and Mediterranean Posidonia oceanica, and mixed meadows in the subtropical and tropical Caribbean which are dominated by only three species - Thalassia testudinum, Syringodium filiforme and Halodule wrightii (Duarte 1999). Indo-Pacific tropical meadows, such as those found in SE Asia, Australia and East Africa, have greater species diversity than their Caribbean counterparts and multi-specific areas are very common with as many as 14 species intermixed in dense shallow meadows (Short et al. 2007). Processes driving diversity patterns in these speciose systems may differ from those driving diversity in predominately subtidal Caribbean. 
Disturbance is one process that can maintain local plant species diversity in a range of ecosystems (see Pickett and White, 1985 for review). The role of disturbance in maintaining seagrass species diversity and co-existence for seagrasses are often referred to, but there is very little data to support this assumption. Seagrass disturbance includes a broad range of natural and anthropogenic processes, from physical events such as storms and boat groundings to biological events such as bioturbation (see Short and WyllieEcheverria, 1996 for review). Most studies have described disturbance as having negative influences on physical, chemical and biological processes in seagrass communities (Asmus and Asmus 2000). However, disturbances also may act as a positive influence in maintaining species diversity and in promoting seagrass coexistence in these space-limited communities. Specifically, the removal of seagrass due to physical disturbance may increase local diversity by allowing normally inferior competitors to successfully colonize the open space, resulting in a mosaic of patches that represent different successional stages (Duarte et al. 1997).

The potential interaction between disturbance and stress in Indo-Pacific intertidal zones make them ideal systems for examining the relative importance of different factors that influence plant species diversity. Intertidal factors are not regularly included in existing seagrass succession models for the Indo-Pacific (e.g. Rollon et al. 1998), even though they may have a strong affect on seagrass composition and dynamics following disturbance and extensive tidal zones are common throughout the region. The tidal amplitude in much of the Indo-Pacific is greater than the Caribbean, resulting in 
expansive meadows that are exposed to air during low tide. Also, intertidal seagrasses may be more susceptible to wind and wave driven processes (Martinez-Crego et al. 2008) than are subtidal seagrasses. Furthermore, increased exposure time and proximity to anthropogenic impacts such as human harvesting activities and boat damage may selectively impact intertidal seagrasses to a greater extent.

Factors regulating seagrass species diversity within Indo-Pacific meadows were examined using extensive field surveys that included sites representing an intertidal gradient on Inhaca Island, Mozambique, East Africa. Previous reports of seagrass zonation and diversity have already been compiled for this island (Bandeira 2002). The purpose of this study was to expand previous work on species distribution patterns in East Africa by looking explicitly at how the tidal gradient, disturbance regime and abiotic conditions influences these distribution patterns.

The specific objectives are to (1) describe distribution and diversity patterns of seagrasses across the intertidal landscape, (2) describe how environmental factors (exposure stress, disturbance regime, sediment characteristics) change across the intertidal landscape and, (3) examine any relationships between seagrass species diversity patterns and these environmental factors? A conceptual model is presented that describes seagrass distribution and species diversity patterns across a tidal gradient under natural disturbance and stress regimes. 


\section{Methodology}

\section{Study Site}

Inhaca Island is located off the east coast of southern Mozambique between latitudes $25^{\circ} 58^{\prime}$ and $26^{\circ} 05^{\prime} \mathrm{S}$ and longitudes $32^{\circ} 55^{\prime}$ and $33^{\circ} 00^{\prime} \mathrm{E}$, and has a shoreline of ca. $60 \mathrm{~km}^{2}$. Tides are semi-diurnal and vary from 0.26 and $3.83 \mathrm{~m}$, with average amplitude for spring and neap tides of $3.2 \mathrm{~m}$ and $1.5 \mathrm{~m}$, respectively (Instituto Nacional de Hidrografia e Navegação 1999). Seagrasses cover approximately 50\% of the Inhaca intertidal zone (Bandeira 2002), are found in areas ranging from muddy to rocky habitats, and are highly diverse with seven species in three families. Seagrasses are absent from the eastern side of this island due to the steep slope of the shoreline and exposure to high-energy waves and winds from the West Indian Ocean. The northern and southern bays are well protected and contain extensive continuous seagrass meadows that are interrupted occasionally by channels. The western side of the island faces Maputo Bay and has a large intertidal zone dominated by sand flats. Along these flats is a narrow zone of seagrass before a sharp drop off into deeper waters. Inhaca Island is also characterized by relatively minimal human impact due to low human population densities. 


\section{Synoptic Survey}

Patterns of seagrass distribution, environmental factors, and disturbance intensity were examined across an intertidal gradient during an extensive field survey conducted between August 7 - 29, 2006 (Figure 2.1). Spatial grids were used to generate site coordinates that were separated by at least 250 meters and represented the entire intertidal zone of Inhaca Island. Additional sites were designated while walking between the predetermined grid sites. A total of 413 sites were sampled for seagrass parameters by placing three $0.25 \mathrm{~m}^{2}$ quadrats at random within $5 \mathrm{~m}$ of the global positioning system (GPS) coordinates. Percent benthic cover of each seagrass species was determined using a modified visual assessment scale of seagrass cover within the quadrat (Fourqurean et al. 2001): $1=0-5 \%, 2=5-25 \%, 3=25-50 \%, 4=50-75 \%$, and $5=75-100 \%$. Species-specific canopy height ( $80 \%$ of the tallest leaf) and water depth at low tide was also recorded in each quadrat.

Intertidal seagrasses were defined in this study as plants inhabiting an area where seagrass leaves would be partially exposed to air at spring low tides. Three distinct seagrass intertidal zones exist along the intertidal gradient and can be defined based on standing water depth at mean low tide, frequency of air exposure (days/month), and dominant seagrass assemblages. These gradients were: Upper intertidal $(0 \mathrm{~cm}$ standing water, exposed ca. 28 days, Halodule uninervis dominant or un-vegetated), Middle intertidal (1-10 cm standing water, exposed ca. 16 days, Thalassia hemprichii dominant), 
and Lower intertidal (10-30 cm standing water, exposed ca. 7 days, Thalassodendron ciliatum dominant). Sites were selected without prior knowledge of placement along the tidal gradient in order to ensure a non-biased spatially balanced selection across the intertidal zone, which resulted in different numbers of sites in each tidal gradient. Sites were visited only at low tide.

\section{Sediment and plant characteristics}

Before sampling began, 79 sites were selected that captured land-sea gradients across the island. These sites were used to conduct a more detailed study of selected environmental conditions that may influence seagrass distribution: sediment organic content and bulk density, porewater redox potential and $\mathrm{pH}$, and seagrass leaf content. Three short shoots of each species present were collected at each site. The leaves were scraped gently to remove epiphytic material, dried, homogenized to a fine powder, and analyzed for carbon, nitrogen (CHN analyzer) and phosphorus content (Fourqurean et al. 1992). Two sediment cores $(10 \mathrm{ml}, 14 \mathrm{~mm}$ diameter $)$ were collected at each site and dried at $70{ }^{\circ} \mathrm{C}$ for 48 hours to obtain bulk density (dry sediment weight / volume). Dry samples were ground using a ceramic mortar and pestle, sediments were ashed at $500{ }^{\circ} \mathrm{C}$ for four hours and percent organic content was calculated as loss on ignition (LOI). Porewater was collected using a stainless steel sampler (Berg and McGlathery 2001) at a depth of $10 \mathrm{~cm}$, which is the average depth of the rhizosphere based on pre-survey biomass sampling on Inhaca Island (Muth, unpublished data). Samples were analyzed twice in-situ for redox 
potential (OAKTON double junction ORPtestr 10) and pH (Waterproof Double Junction pHTestr 10) at each site.

\section{Disturbance intensity}

Disturbed areas were defined as un-vegetated patches located within a continuous seagrass meadow. Quantification of disturbances was conducted at 44 sites that were randomly selected from the 79 sites in the sediment survey. At each of these 44 sites, number and size of all bare gaps found within one transect $(6 \mathrm{~m} \times 30 \mathrm{~m})$ parallel to shore were measured. For each gap identified, the disturbance type (sediment burial, sediment removal, level with surrounding seagrass) and size (1-5 scale of maximum gap width; $1=$ $<0.25 \mathrm{~m}, 2=0.25-0.5 \mathrm{~m}, 3=0.5-1 \mathrm{~m}, 4=1-5 \mathrm{~m}, 5=>5 \mathrm{~m})$ was recorded. The percentage of total area occupied by disturbances within continuous seagrass meadows was calculated by multiplying the number of gaps with the average gap area for each size class and summing results of all size classes.

\section{Statistical analyses}

Seagrass, sediment and disturbance data were analyzed for descriptive and spatial patterns. Diversity of seagrass was described using two indices: Species richness and the Shannon Diversity index (Shannon 1948), which incorporates the relative proportion and evenness of each species at a given site. Data were log transformed as needed to meet the assumptions of population variance and normality. Analysis of variance tests were 
performed on transformed data using a general linear model (GLM) to determine if there was a significant effect of location (intertidal zone) on seagrass species richness and disturbance parameters. Because the primary goal was to obtain a spatial representation across the intertidal landscape, rather than select sites based on a depth gradient, an unequal sample size was used within each seagrass intertidal zone. Post-hoc tests were performed using Hochberg's test (equal variance) or Games-Howell test (unequal variance) because they are effective with unequal sample sizes(Field 2009). Relationships between seagrass and environmental parameters were analyzed using Pearson's Correlation coefficients and regression analysis.

\section{Results}

\section{Seagrass distribution and diversity}

Seagrass plants were found at $71 \%(n=305)$ of all 413 intertidal sites. Most seagrass beds were dense, with the majority of sites having between $50-75 \%$ cover (162 of 305 sites, $53 \%$ of all sites), and only 10 sites with less than 5\% cover. Eight species were identified on Inhaca Island; Cymodocea rotundata, Cymodocea serrulata, Halodule uninervis, Halophilia ovalis, Nanozostera capensis, Syringodium isoetifolium, Thalassia hemprichii, and Thalassodenron ciliatum. Although previous studies in the region separated Halodule uninervis from Halodule wrightii based on morphological characteristics (Bandeira, 2002), both Halodule species were pooled together because of recent molecular evidence that Halodule in East Africa is the same species (Waycott 
2009). The most frequently encountered species were $H$. uninervis $(\mathrm{n}=200 ; 65 \%)$ and $T$. testudinum $(\mathrm{n}=144 ; 49 \%)$. The least common species were $H$. ovalis $(\mathrm{n}=18 ; 6 \%), S$. isoetifolium $(\mathrm{n}=43 ; 15 \%)$ and $N$. capensis $(\mathrm{n}=52 ; 18 \%)$. Co-existence of seagrass species was also common; $71 \%$ of the sites had greater than one species present, with a maximum of seven species found at a given site (Figure 2.2a). Monospecific meadows were most common along the extremes of the tidal gradient, with $H$. uninervis in the upper limits and T. ciliatum in the lower limits.

The most common community type as defined by the dominant species of seagrass present was Halodule $(\mathrm{n}=108,35.0 \%)$, followed by Thalassia $(\mathrm{n}=53,17.2 \%)$, and Thalassodenron $(\mathrm{n}=39,12.6 \%)$ (Figure 2.2b). Syringodium $(\mathrm{n}=17,5.5 \%)$ and Nanozostera $(n=9,2.9 \%)$ were the only intertidal seagrasses found exclusively in mixed meadows, although monospecific Syringodium stands were observed in deeper subtidal regions that were not part of this intertidal study. Thalassodenron was the only seagrass that was more often found in monospecific meadows rather than mixed with other species. The only instances were two dominant seagrasses were had equal densities were Thalassia with Halodule $(\mathrm{n}=23,7.4 \%)$, and Halodule with Nanozostera $(\mathrm{n}=9,2.9 \%)$. All eight species found on Inhaca Island were associated with only three community types; Halodule, Halodule-Thalassia, and Thalassia (Appendix 1). Zonation of seagrass community types was found along the tidal gradient (Figure 2.3); smaller narrow leafed species (e.g. Nanozostera and Halodule) dominated in the higher zones and larger species (e.g. C. serrulata, Thalassodendron) were dominant in the lower zones. The distribution 
patterns of seagrass species within tidal zones did not differ based on geographical location around the island, except for Nanozostera, which was found almost exclusively intermixed with Halodule on the southern offshore banks.

Total seagrass abundance $\left(\mathrm{F}_{2,294}=8.90, p<0.001\right)$ and species richness $\left(\mathrm{F}_{2,294}=74.16, p\right.$ $<0.001)$ differed between intertidal zones. Abundance was highest in middle (mean $=$ $58.1 \%$ cover $)$ and lower $($ mean $=56.4 \%$ cover $)$ intertidal zones and lowest in the upper intertidal zone $($ mean $=46.3 \%$ cover $)($ Figure 2.4$)$. Sites with $100 \%$ cover values were observed more frequently in deeper zones containing monospecific T. ciliatum strands. Species richness was highest in the middle intertidal zone (mean $=3.36)$, and reduced in the upper $($ mean $=1.78)$ and lower $($ mean $=1.93)$ intertidal zones. Values for both the Shannon diversity index $\left(\mathrm{H}^{\prime}\right)$ and Eveness $\left(\mathrm{E}_{\mathrm{H}}\right)$ were highest at the middle intertidal zone (Table 2.1).

\section{Abiotic conditions}

No significant difference $(p<0.05)$ was found between tidal zones for abiotic sediment (organic content, bulk density) and porewater (redox potential, $\mathrm{pH}$ ) (Table 2.2). The upper intertidal had no remaining standing or pooled water during mean low tide and the entire aboveground biomass was exposed to the air. The mean standing water depth was $4.3 \mathrm{~cm}$ at the middle intertidal and $19.2 \mathrm{~cm}$ at the lower intertidal at mean low tide. Although temperature readings were not taken at all sites, permanent study sites located in each of the intertidal zones showed that the upper intertidal had the greatest annual 
temperature range as well as the most extreme values at both ends of the temperature gradient $\left(10.8^{0} \mathrm{C}\right.$ to $\left.46.5{ }^{0} \mathrm{C}\right)$.

Nutrient content of leaves has been used to estimate relative nutrient availability for plants and to serve as an indicator of nutrient limitation (Duarte, 1990). Mean nutrient values ( \pm se) for Thalassia hemprichii, a species common to all three zones, was 2.83 (0.07) for total nitrogen, $0.22(0.01)$ for total phosphorus, and $28.68(0.09)$ for N:P ratios across the entire study zone. The only variable that showed a significant difference between different intertidal zones was total nitrogen $\left(\mathrm{F}_{2,42}=6.37, p=0.004\right)$, which was lower in the lower intertidal zones (Table 2.2). Additional data on leaf nutrient content for all seagrass species can be found in Appendix 2.2.

\section{Disturbance}

All sites where seagrass was sampled contained bare gaps that were disturbance-driven. This contributed to the overall heterogeneity of seagrass habitats. Two distinct mechanisms of disturbance were observed: sediment burial and sediment removal. Sediment burial was more common than sediment removal in this area (Figure 2.5, Table 3). There was a significant difference between intertidal zones regarding both total area disturbed $\left(\mathrm{F}_{3,39}=4.72, p=0.007\right)$ and number of disturbances $\left(\mathrm{F}_{3,39}=3.11, p<0.037\right)$. Mean disturbance area and number of disturbances per transect across all sites were $16.17 \%$ and 47.3 , respectively. Disturbance parameters declined with depth and were highest in the upper intertidal (mean area disturbed $=21.38 \%$, mean number of 
disturbances $=74$ ) and lowest in the lower intertidal (mean area disturbed $=7.00 \%$, mean number of disturbances $=16$ ) (Figure 2.4). Although the majority of sites were characterized by relatively low disturbance $(<20 \%$ of the area disturbed), some sites had disturbances that covered over half of the meadow. Bioturbation as an agent of disturbance was visually assessing disturbance patterns (e.g. types of mounds) that were unique to specific taxa such as holothurians, shrimp, crabs and fish (see Appendix 2.3 for bioturbation photos).

\section{Discussion}

\section{Factors influencing species diversity: Environmental factors}

This study documents a unimodal pattern of seagrass species diversity across the intertidal landscape, where diversity was greatest in the middle intertidal zone and decreased in the upper intertidal and subtidal fringes. Plant stress is likely the primary factor responsible for reduced species diversity in the upper intertidal zone due to the limited number of seagrass species able to tolerate extended periods of irradiance and desiccation during low tide exposure. Similar patterns have been documented in other Indo-Pacific locations (Erftemeijer and Herman 1994, Carruthers et al. 2007). The exact mechanism of stress adaptation by these few species is still unclear, and studies have shown that intertidal species actually exhibit greater sensitivity to UV radiation (Dawson and Dennison 1996) and desiccation (Shafer et al. 2007) than their subtidal counterparts. 
Bjork et al. (1999) suggest that Halodule uninervis, the most abundant and frequently encountered species found within the upper intertidal species in our study, is able to physically minimize water loss by allowing leaves to overlap and lie flat on the exposed moist sand, rather than responding to exposure stress with physiological adaptations. Halodule uninervis also creates seed banks (Orth et al. 2000) that may further contribute to species persistence during severe stress events such as high water temperatures and extreme low tides when seeds accumulate in micro-depressions within the intertidal sediments (Inglis 2000). Although seed bank presence was not quantified at all sites, a large number of $H$. uninervis seeds were observed only in the upper intertidal sediment. Additional studies are needed to determine if seed banks are important contributors to species survival during exposure stress.

While smaller-sized species (Halodule uninervis, Nanozostera capensis) dominate the upper intertidal, the presence of moderate-sized species (T. hemprichiia and $C$. rotundata) within the upper intertidal zone indicates some form of adaptation to exposure stress, either by more rapid re-submersion recovery (Lan et al. 2005) or resilience to biomass loss via nutrient storage in their relatively larger belowground tissues (Stapel et al. 1997). Upper intertidal T. hemprichii leaves were considerably smaller than their deeper counterparts, indicating a certain degree of morphological plasticity, but this species was still restricted to small depressions containing a few millimeters of water at mean low tide, and displayed signs of exposure stress such as leaf burning. The absence of other species in the upper intertidal, such as $S$. isoetifolium and T. ciliatum, may be 
related to direct repression by high irradiance (Fokeera-Wahedally and Bhikajee 2005). While tidal exposure was the primary stress factor influencing diversity in this locale, patterns of decreasing seagrass diversity have been documented along other stress gradients, such as sedimentation and siltation (Verheij and Erftemeijer 1993) and low salinity (Long et al. 1993).

Sediment conditions (organic content, bulk density, porewater $\mathrm{pH}$ and redox potential) do not appear to be a primary factor that influences landscape patterns of seagrass disturbance and abundance. No significant differences were found between the three intertidal zones for sediment parameters, although studies in other Indo-Pacific meadows found low correlations between sediment characteristics and species diversity patterns (Tanaka and Kayanne 2007). Therefore, sediment parameters may not be a good predictor of plant diversity patterns across some intertidal zones.

\section{Factors influencing species diversity: Biological factors}

Reduced diversity in the lower intertidal is likely a result of exploitative competition, a form of indirect interspecific competition for resources in which one species reduces the availability of a resource for other species. Correlative support for this competitive mechanism can be found by looking at species distribution and abundance patterns. Although all 8 seagrass species found on Inhaca Island are able to grow in the lower intertidal based on their presence in the survey, this deeper intertidal zone was dominated by species with longer and wider leaves (e.g. C. serrulata, T. ciliatum). These larger 
species reduce the availability of space and light for other competitors, which can inhibit the survival or expansion of smaller sized species. Few studies have examined explicitly the role of seagrass competitive interactions and how individual seagrass species growth is suppressed by the presence of other seagrass species. Experiments in tropical seagrass systems have demonstrated the capacity of smaller fast-growing species (e.g. H. ovalis, H. uninervis, S. isoetifolium) for opportunistic growth following the removal of largersized species (e.g. T. hemprichii) (Duarte et al. 1997, Bach et al. 1998, Rollon et al. 1998, Rasheed 2004)(Chapter 3). Duarte et al. (2000) attempted to test for competitive interactions, but removing the large-sized seagrass Enhalus acoroides in SE Asia did not result in the predicted positive increase of smaller species. However, the authors suggests that the experimental time of three months may not have been sufficient to see a response. More experimental tests are needed to explicitly address the role of competitive interactions in structuring mixed seagrass communities.

In addition to limitations of space and light resources, competition for nutrients has been shown to affect seagrass co-existence. Competition for groundwater nitrogen has been linked to reduced species diversity in an East African back-reef lagoon containing 10 species (Kamermans et al. 2002), although the partitioning of sediment nutrients may reduce this competition and facilitate co-existence (Patriquin 1975, Williams 1987, Williams 1990). It is unlikely that nutrient availability played a role in our system because mean values of leaf nutrient content were well above estimates at which seagrass may be considered nutrient limited $(<1.8 \%$ nitrogen, $<0.2 \%$ phosphorus) (Duarte 
1990). Additionally, a 20-month nitrogen and phosphorus enrichment experiment at three sites characteristic of typical upper, middle and intertidal zones resulted in no changes in species density or canopy height except for an increase in $N$. capensis shoot density at the upper middle intertidal (Appendix 2.4a and 2.4b). So, while nutrient availability may be important at a localized species scale, no general nutrient gradient exists in this study that can explain diversity patterns along vertical zones.

\section{Factors influencing species diversity: Disturbance}

This study is one of only a few to quantify disturbance extent within seagrass meadows (e.g. Bell et al., 1999) and supports previous assertions that the importance of small-scale disturbances to seagrass dynamics are underestimated (Duarte et al. 1997) and may increase landscape heterogeneity (Valentine et al. 1994). We found that small-sized disturbances $(<25 \mathrm{~cm}$ in width) created by either wind-driven events or bioturbation activities were common across the intertidal landscape, especially in the upper intertidal zone.

The higher disturbance intensity in the upper intertidal zone can be related both to the greater susceptibility to sediment movement due to wind and waves and to the higher density of bioturbating organisms that rework the sediment in these upper zones (see Appendix 2.3 for photos of bioturbation disturbances). While the presence of specific bioturbators is largely a function of their species-specific requirements for air exposure, the species of seagrass may also be influencing the presence and activity of those 
burrowing organisms. For example, dominant upper intertidal seagrasses tend to have less belowground plant material (rhizomes, roots) compared to those species more common in deeper intertidal zones, which produces an environment more beneficial for bioturbators requiring soft sediment such as sea cucumbers. In contrast, reduced bioturbation in the lower intertidal zones may be inhibited by the extensive root-rhizome complex characteristic of the larger dominant seagrass. In addition to the overall lack of bioturbators in the deeper intertidal zone, reduced disturbance intensity observed in the lower intertidal zone may also be a function of resilience to sediment burial by larger seagrass species such as T. ciliatum (Duarte et al. 1997, Bach et al. 1998, Nakaoka et al. 2004), which is the most common type of disturbance in our study.

The primary disturbance regime identified in this study can affect local and diversity patterns by impacting the overall survival and recovery rate of a specific species following disturbance. Soft-bottom sandy substrates inhabited by seagrasses can easily be shifted during disturbances, resulting in either sediment excavation or burial that creates a combination of depressions and mounds within the meadow (see Cabaco et al., 2008 for review). This mosaic of vegetated and un-vegetated patches was observed in this study and was most prominent in the upper intertidal. The formation of mounds and depressions lead to the formation of new microhabitats that can either increase or decrease species diversity depending on the particular tidal zone where they are found. For example, burial of even a few centimeters in the upper intertidal zone appears to extend the exposure stress beyond tolerance thresholds, as evident by the absence of plant 
colonization on these mounds. Sediment removal in the same zone may provide enough standing water to allow for other species to exist that would normally be excluded.

Therefore, the relative importance of disturbance type on local seagrass species diversity may be greatest in the middle intertidal, even if the overall numbers of disturbances are higher in the upper intertidal. This is because the number of possible microhabitats derived from sediment burial and removal is highest in the middle intertidal, and therefore could potentially support more unique species combinations compared to the other zones combinations (Figure 2.6b). Bandeira (2002) suggested that both macro-scale patterns such as tidal gradient, and micro-scale processes such as small topographical changes created by disturbances, might influence seagrass distribution patterns on Inhaca Island. The increased spatial coverage and the addition of quantifying the disturbance regime examined in this study provide additional evidence to support the importance of both macro- and micro- scale processes in regulating species diversity patterns.

\section{Interactions between stress, competition and disturbance}

The three factors addressed in this study - stress, interspecific competition and disturbances - have been used in several ways by community ecologists to predict and explain plant distribution patterns. One example is Philip Grime's C-S-R (CompetitorStress-Ruderal) Triangle Model (Grime 1977), which classifies plant functional types based on life strategy tradeoffs along relative intensities of stress, competition and disturbance. In this model, ruderal fast growing species tend to have a low tolerance for 
stress. The seagrass intertidal zone is a good example of where the Grimes model does not fit, because our fast-growing ruderal species are also those most tolerant to exposure stress in the upper intertidal (H. uninervis).

Stress, competition and disturbance are frequently used as key processes in ecological models that describe patterns of species diversity. Most notable is the Intermediate Disturbance Hypothesis (IDH) (Connell 1978, Paine and Levin 1981). This model describes highest diversity at intermediate levels due to competitive exclusion when disturbance is low and elevated stress when disturbance is high. Our findings follow the IDH pattern in that diversity was highest at moderate levels of disturbance; however, the processes controlling our observed patterns deviate somewhat from those described in original theories. For example, an opportunistic species (H. uninervis) is dominant in the high disturbance upper intertidal zones, as the IDH predicts, but this phenomenon is more likely a result of tolerance for high levels of exposure stress, with disturbance tolerance acting as a secondary factor. Where our study and the IDH model most deviates is the mechanism to promote higher diversity. The IDH and other theories such as the Patch Dynamic Theory assumes that disturbance generated plant removal processes leads to a mosaic of patches undergoing different stages of recovery in terrestrial (Pickett and White 1985) and rocky intertidal zones (Paine and Levin 1981, Sousa 1984). While some opportunistic species exist in the intertidal zone, recovery from small-scale disturbances is largely dependent on vegetated colonization from species along the edge rather than new propagules via sexual reproduction (Rasheed 2004). Thus, if sediment depth is not 
altered then a small gap will more likely return directly to the pre-disturbance composition (Rollon et al. 1998)(Chapter 3) without a successional intermediate. Disturbances bring about changes in standing water are required to shift the competitive outcome which helps promote new species recruitment and maintain local diversity (Chapter 3). Sediment burial disturbances in the intertidal can also promote species coexistence in mixed meadows through selective mortality based on species-specific burial tolerances (Duarte et al. 1997).

\section{Summary}

This study describes a unimodal pattern of seagrass species diversity extending across an intertidal landscape that is likely a result of both macro- and micro-scale processes (Figure 2.6a). Key results that may be applicable to other soft-bottom intertidal habitats include (1) upper intertidal stress and lower intertidal competitive interactions decreases species diversity at the endpoints of the intertidal gradient, (2) small-scale disturbances are common and important contributors to the overall heterogeneity of the intertidal landscape and (3) these disturbances may increase local diversity by creating a mosaic of unique microhabitats caused by small topographical changes in sediment depth. To my knowledge, this is the first study to quantify disturbance intensity across an Indo-Pacific tidal gradient. Our conceptual model describes key processes acting simultaneously to maintain seagrass co-existence (exposure stress, small-scale disturbance, interspecific competition), but it is based on observational data. Additional experimental work is needed to test our interpretation of diversity patterns. Nevertheless, descriptive studies on 
seagrass diversity such as this one provide important baseline information to explore underlying processes responsible for the patterns, create a framework to examine links between plant diversity and other ecological processes, and allow for the prediction of how plant diversity patterns may change under different scenarios such as climate change, species introductions, and changing disturbance regimes. 


\section{References}

Asmus, H. and R. Asmus. 2000. Workshop on Intertidal Seagrass Beds and Algal Mats: Organisms and fluxes at the ecosystem level. Helgoland Marine Research 54: 5354.

Bach, S. B., J. B. Borum, M. D. Fortes, and C. M. Duarte. 1998. Species composition and plant performance of mixed seagrass beds along a siltation gradient at Cape Bolinao, The Phillipnes. Marine Ecology Progress Series 247-256.

Bandeira, S., 2002. Diversity and distribution of seagrasses around Inhaca Island, southern Mozambique. South African Journal of Botany 68: 191-198.

Berg, P. and K. J. McGlathery. 2001. A high-resolution pore water sampler for sandy sediments. Limnology and Oceanography 46: 203-210.

Bjork, M., J. Uku, A. Weil, and S. Beer. 1999. Photosynthetic tolerances to desiccation of tropical intertidal seagrasses. Marine Ecology Progress Series 191: 121-126.

Cabaco, S., R. Santos, and C. M. Duarte. 2008. The impact of sediment burial and erosion on seagrasses: A review. Estuarine Coastal Shelf Science 79: 354-366.

Carruthers, T. J. B., W. C. Dennison, G. A. Kendrick, M. Waycott, D. I. Walker, and M. L. Cambridge. 2007. Seagrasses of south-west Australia: A conceptual synthesis of the world's most diverse and extensive seagrass meadows. Journal of Experimental Marine Biology and Ecology 350: 21-45.

Connell, J. H., 1978. Diversity of tropical rain forests and coral reefs. Science 199: 13021310.

Dawson, S. P. and W. C. Dennison. 1996. Effects of ultraviolet and photosynthetically active radiation on five seagrass species. Marine Biology 125: 629-638.

den Hartog, C. and J. Kuo. 2006. Taxonomy and biogeography of seagrasses, pp. 1-23 in Seagrasses: Biology, Ecology and Conservation, edited by A. W. D. Larkum, R. J. Orth and C. M. Duarte. Springer.

Duarte, C. M., 1990. Seagrass nutrient content. Marine Ecology Progress Series 6: 201207.

Duarte, C. M., 1999. Seagrass ecology at the turn of the millennium: challenges for the new century. Aquatic Botany 65: -20 .

Duarte, C. M., J. Terrados, N. S. R. Agawin, and M. D. Fortes. 2000. An experimental test of the occurrence of competitive interactions among SE Asian seagrasses. Marine Ecology Progress Series 197: 231-240.

Duarte, C. M., J. Terrados, N. S. R. Agawin, M. D. Fortes, S. Bach, and W. J. Kenworthy. 1997. Response of a mixed Philippine seagrass meadow to experimental burial. Marine Ecology Progress Series 147: 285-294.

Erftemeijer, P. L. A. and P. M. J. Herman. 1994. Seasonal changes in environmental vairables, biomass, production and nutrient contents in 2 contrasting tropical intertidal seagrass beds in South Sulawesi, Indonesia. Oeccologia 99: 45-59.

Field, A. P., 2009. Discovering statistics using SPSS. Sage Publications. 
Fokeera-Wahedally, S. B. M. and M. Bhikajee. 2005. The effects of in situ shading on the growth of a seagrass, Syringodium isoetifolium. Estuarine Coastal Shelf Science 64: 149-155.

Fourqurean, J. W., A. Willsie, C. D. Rose, and L. M. Rutten. 2001. Spatial and temporal pattern in seagrass community composition and productivity in south Florida. Marine Biology 138: 341-354.

Fourqurean, J. W., J. C. Zieman, and G. V. N. Powell. 1992. Relationships between porewater nutrients and seagrasses in a subtropical carbonate environment. Marine Biology 114: 57-65.

Grime, J. P., 1977. Evidence for the existence of three primary strategies in plants and its relevance to ecological and evolutionary theory. American Naturalist 1169-1194.

Inglis, G. J., 2000. Disturbance-related heterogeneity in the seed banks of a marine angiosperm. Journal of Ecology 88: 88-99.

Instituto Nacional de Hidrografia e Navegação, Mozambique. 1999.

Kamermans, P., M. A. Hamminga, J. F. Tack, M. A. Mateo, N. Marba, M. Mtolera, J. Stapel, A. Verheyden, and T. Van Daele. 2002. Groundwater effects on diversity and abundance of lagoonal seagrasses in Kenya and on Zanzibar Island (East Africa). Marine Ecology Progress Series 231: 75-83.

Lan, C. Y., W. Y. Kao, H. J. Lin, and K. T. Shao. 2005. Measurement of chlorophyll fluorescence reveals mechanisms for habitat niche separation of the intertidal seagrasses Thalassia hemprichii and Halodule uninervis. Marine Biology 148: 2534.

Long, W. J. L., J. E. Mellors, and R. G. Coles. 1993. Seagrasses between Cape York and Hervey Bay, Queensland, Australia. Australian Journal of Marine and Freshwater Research 44: 19-31.

Martinez-Crego, B., A. Verges, T. Alcoverro, and J. Romero. 2008. Selection of multiple seagrass indicators for environmental biomonitoring. Marine Ecology Progress Series 361: 93-109.

Nakaoka, M., Y. Tanaka, and M. Watanabe. 2004. Species diversity and abundance of seagrasses in southwestern Thailand under different influence of river discharge. Coastal Marine Science 75-80.

Orth, R. J., M. C. Harwell, E. M. Bailey, A. Bartholomew, J. T. Jawad, A. V. Lombana, K. A. Moore, J. M. Rhode, and H. E. Woods. 2000. A review of issues in seagrass seed dormancy and germination: implications for conservation and restoration. Marine Ecology Progress Series 200: 277-288.

Paine, R. T. and S. A. Levin. 1981. Intertidal landscapes - Disturbance and the dynamics of pattern. Ecological Monongraphs 51: 145-178.

Patriquin, D. G., 1975. "Migration" of blowouts in seagrass beds at Barbados and Carriacou, West Indies, and its ecological and geological implications. Aquatic Botany 163-189.

Pickett, S. T. A. and B. White. 1985. The ecology of natural disturbances and patch dynamics. Academic Press, Orlando, FL. 
Rasheed, M. A., 2004. Recovery and succession in a multi-species tropical seagrass meadow following experimental disturbance: the role of sexual and asexual reproduction. Journal of Experimental Marine Biology and Ecology 310: 13-45.

Rollon, R. N., E. D. D. Van Steveninck, W. Van Vierssen, and M. D. Fortes. 1998. Contrasting recolonization strategies in multi-species seagrass meadows. Marine Pollution Bulletin 37: 450-459.

Shafer, D. J., T. D. Sherman, and S. Wyllie-Echeverria. 2007. Do desiccation tolerances control the vertical distribution of intertidal seagrasses? Aquatic Botany 87: 161166.

Shannon, 1948. A mathematical theory of communication. Bell System Technical Journal 27: 379-423, 623-656.

Short, F. T. and S. Wyllie-Echeverria. 1996. Natural and human-induced disturbance of seagrasses. Environmental Conservation 23: 17-27.

Short, F., T. Carruthers, W. Dennison, and M. Waycott. 2007. Global seagrass distribution and diversity: A bioregional model. Journal of Experimental Marine Biology and Ecology 350: 3-20.

Sousa, W. P., 1984. Intertidal mosaics - Patch size, propagule availability, and spatially variable patterns of succession. Ecology 65: 1918-1935.

Stapel, J., R. Manuntun, and M. A. Hemminga. 1997. Biomass loss and nutrient redistribution in an Indonesian Thalassia hemprichii seagrass bed following seasonal low tide exposure during daylight. Marine Ecology Progress Series 148: 251-262.

Tanaka, Y. and H. Kayanne. 2007. Relationship of species composition of tropical seagrass meadows to multiple physical environmental factors. Ecological Research 22: 87-96.

Valentine, J. F., K. L. Heck, P. Harper, and M. Beck. 1994. Effects of bioturbation in controlling Turtlegrass (Thalassia testudinum Banks Ex Konig), abundance Evidence from field enclosures and observations in the Northern Gulf of Mexico. Journal of Experimental Marine Biology and Ecology 178: 181-192.

Verheij, E. and P. L. A. Erftemeijer. 1993. Distribution of seagrasses and associated macroalgae in South Sulawesi, Indonesia. Blumea 38: 45-64.

Waycott, M. W., 2009. Global Initiative to Barcode Seagrasses. .

Waycott, M., G. Procaccini, D. H. Les, and T. B. H. Reusch. 2006. Seagrass evolution, ecology and conservation: A genetic perspective, in Seagrasses: Biology, Ecology and Conservation. Springer, The Netherlands .

Williams, S. L., 1987. Competition between the seagrasses Thalassia testudinum and Syringodium filiforme in a Caribbean lagoon. Marine Ecology Progress Series 35: 91-98.

Williams, S. L., 1990. Experimental studies of Caribbean seagrass bed development. Ecological Monographs 60: 449-469. 


\section{Figures}

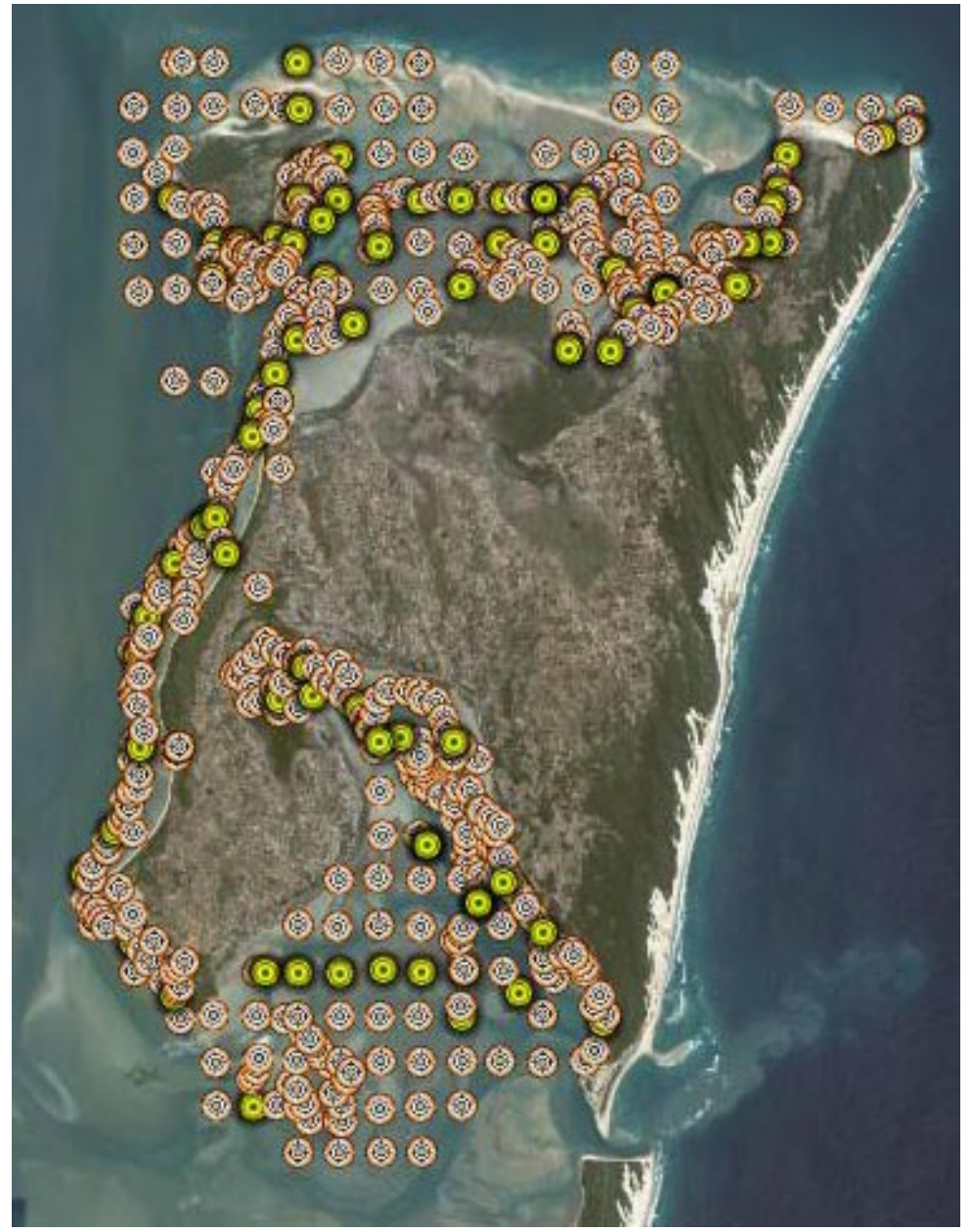

Figure 2.1. Map of Inhaca Island with survey sites.

Seagrass data $(\%$ cover, height) was collected at all symbols $(n=305)$; disturbance and sediment data was collected at the yellow symbols. 

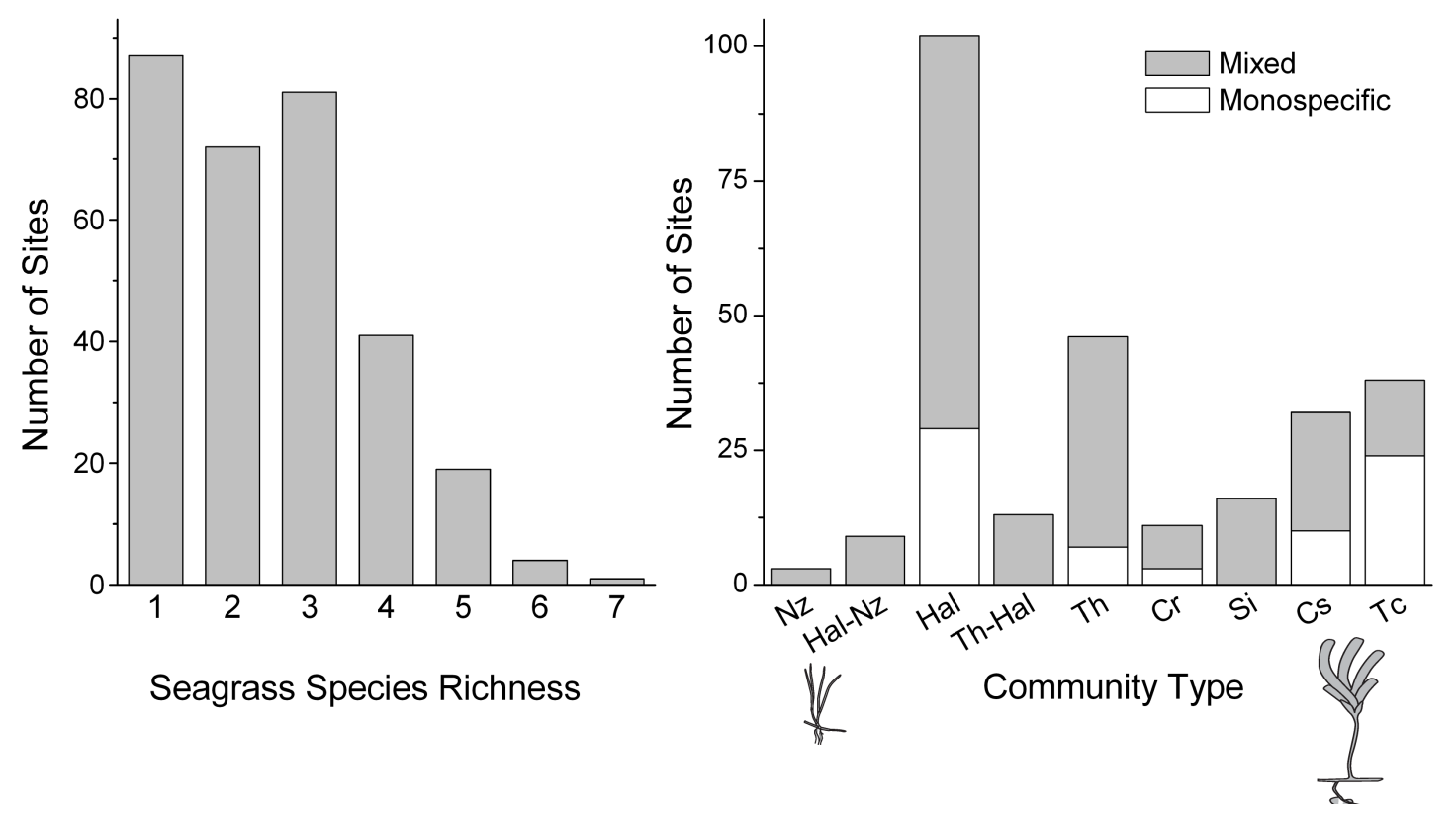

Figure 2.2. Frequency of sites based on (a) species richness (number of seagrass species) and (b) seagrass community type.

Seagrass community type was defined by species having greater than $25 \%$ coverage. $\mathrm{Nz}=$ Nanozostera capensis, Hal $=$ Halodule uninervis, $\mathrm{Th}=$ Thalassia hemprichii, $\mathrm{Cr}=$ Cymodocea rotundata, $\mathrm{Si}=\mathrm{Syringodium}$ isoetifolium, $\mathrm{Cs}=\mathrm{Cymodocea}$ serrulata, $\mathrm{Tc}=$ Thalassodendron ciliatutm. $\mathrm{N}=305$ sites. 


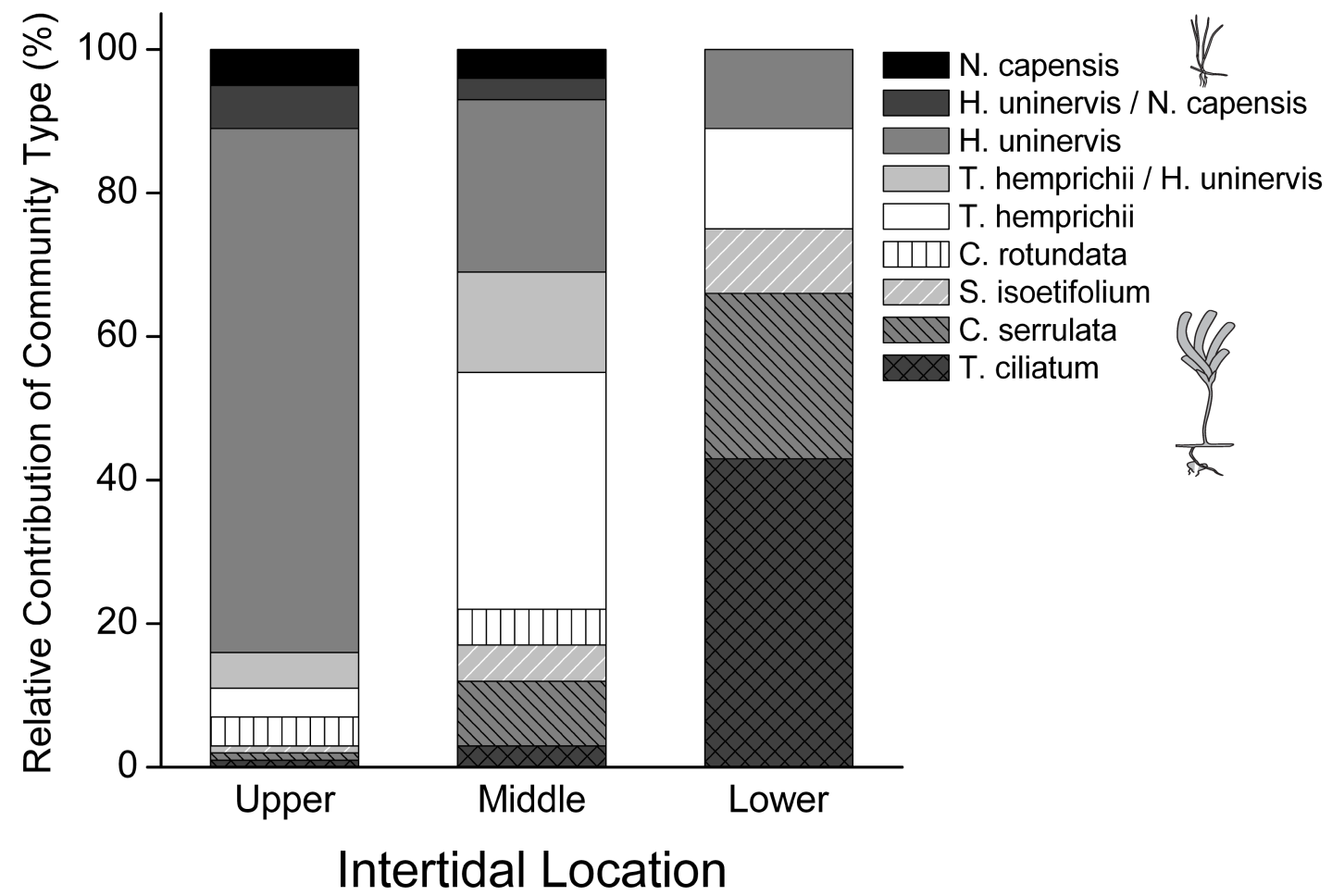

Figure 2.3. Seagrass community type along a tidal gradient. 

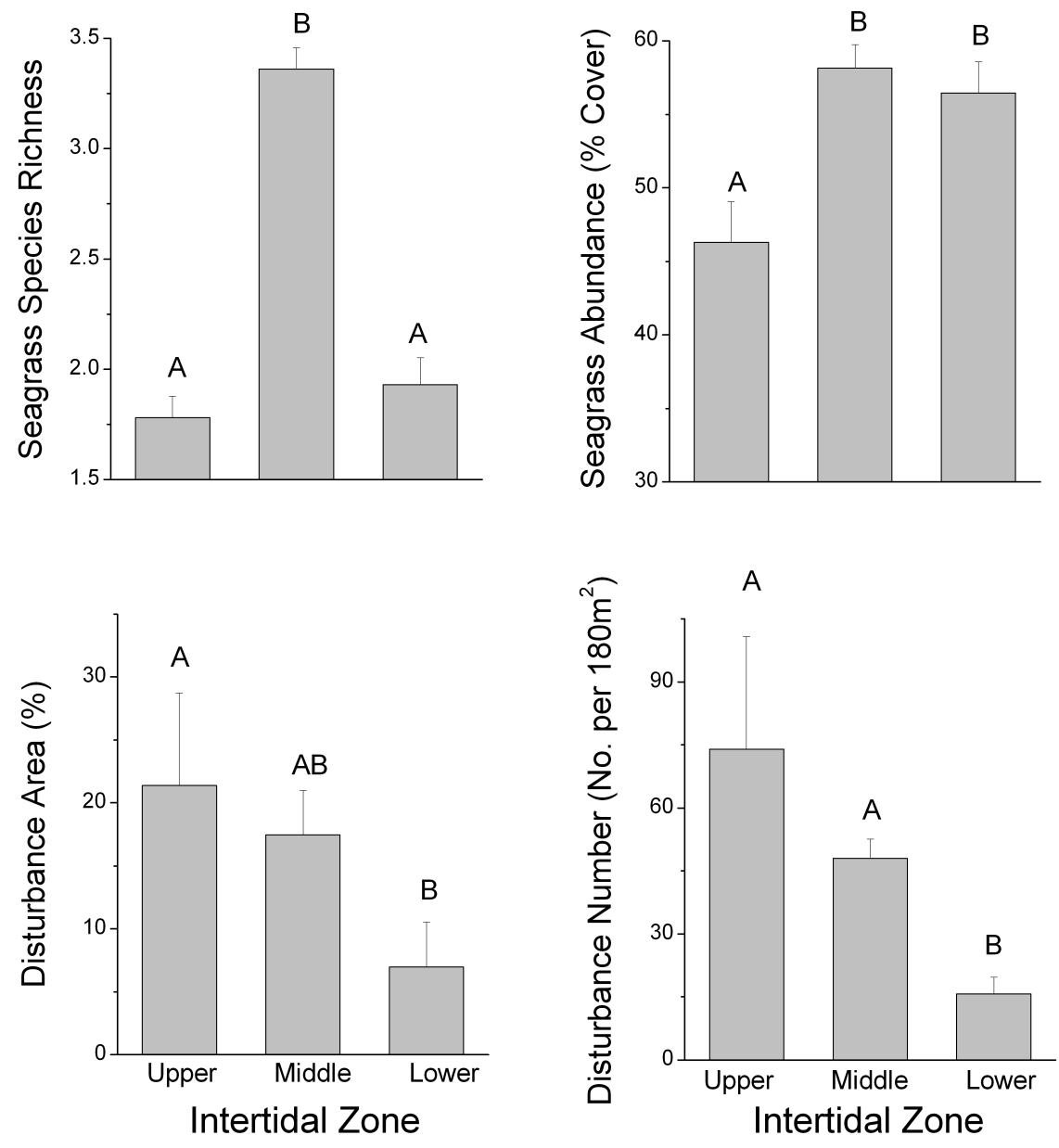

Figure 2.4. Seagrass (species richness and abundance) and disturbance (extent and frequency) parameters along a tidal gradient.

Values are mean \pm se. $\mathrm{N}=44$ sites total, 10 sites for Upper 24 sites for Middle, and 10 sites for Lower intertidal zones. 


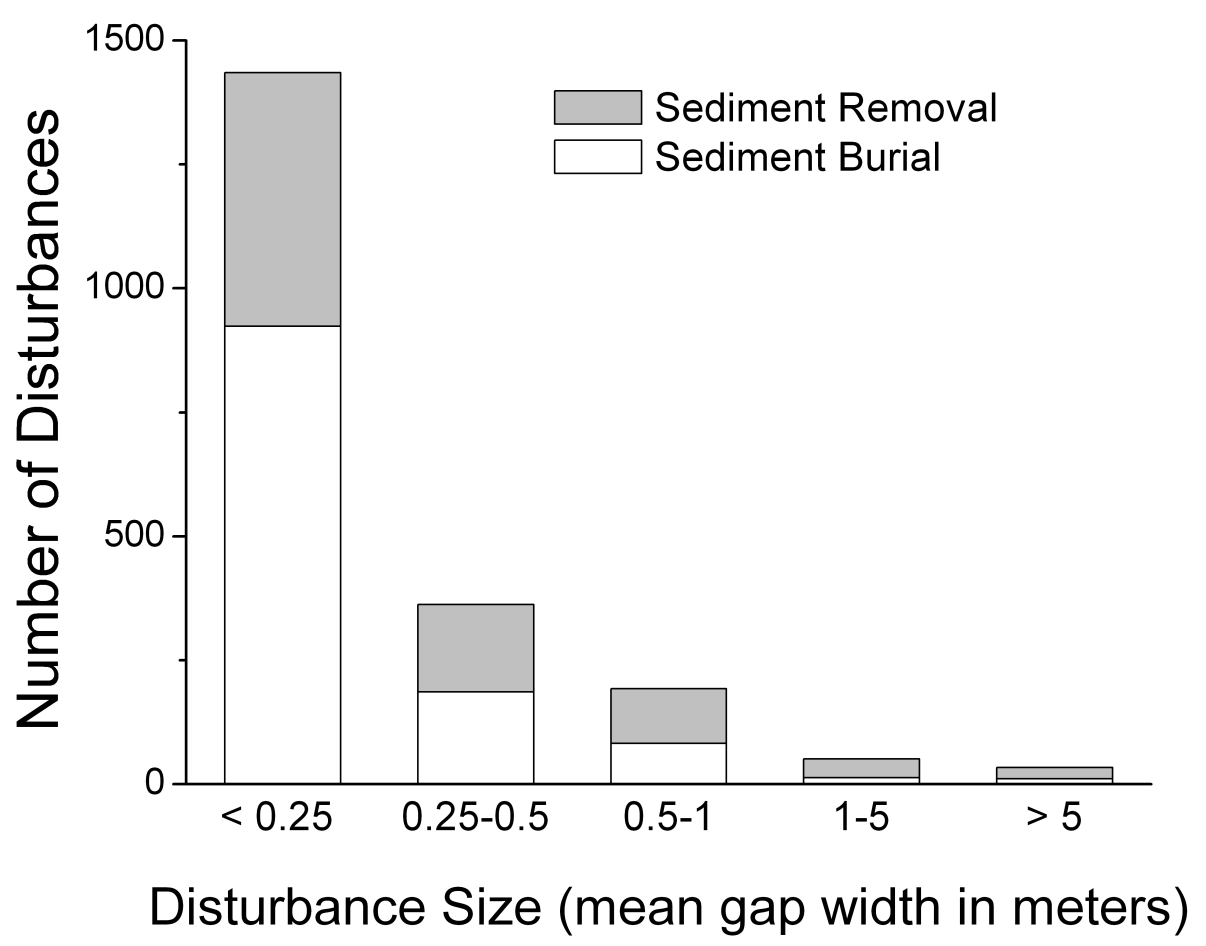

Figure 2.5. Total number of sediment burial and removal disturbances based on disturbance size.

$\mathrm{N}=44$ sites, each with one transect parallel to shore $(6 \mathrm{~m} \times 30 \mathrm{~m})$. 


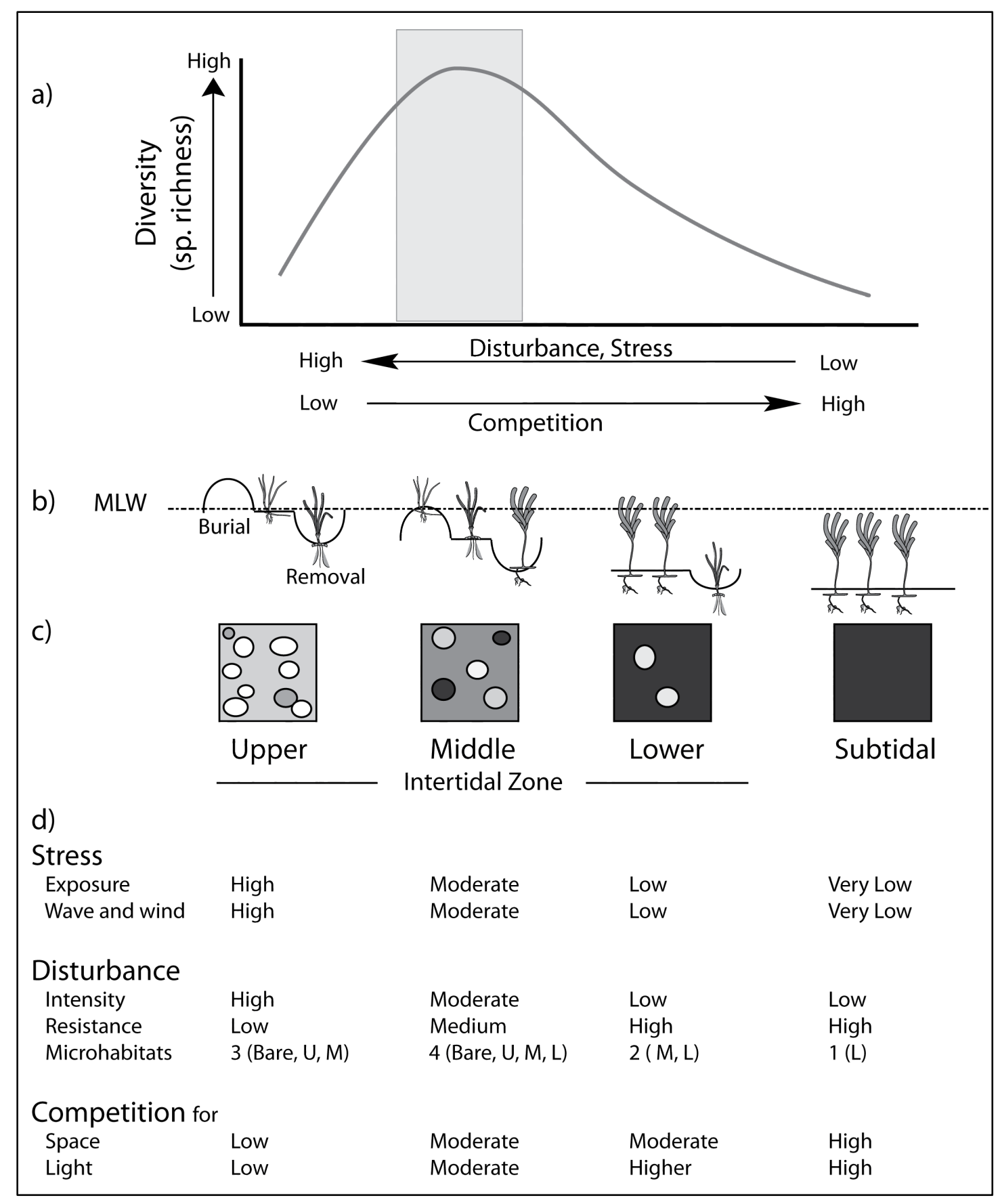

Figure 2.6. Model of relationships between seagrass diversity and disturbance along a tidal gradient.

(a) Model of relationships between seagrass diversity and disturbance along a tidal gradient, where the highest diversity occurs at intermediate levels of disturbance (middle intertidal). (b) Potential species colonization under different disturbance (sediment burial, removal) and tidal regimes. Upper: Burial excludes seagrass in the upper intertidal due to elevated air exposure while Removal removes exposure stress. Middle: Greatest assemblage combinations. Lower 
intertidal and subtidal: Lower disturbance intensity and species richness due high resistance to burials by large sized plants, a lack of bioturbators excavating sediments and competitive displacement of smaller sized plants. (c) Depiction of how disturbance regime affects seagrass patchiness and heterogeneity, with white reflecting bare gaps created by disturbances and colored patches as seagrass assemblages at different recolonization stages (darker colors representing the larger, deeper seagrass species). (d) Summary of relative importance of abiotic stress, disturbance and competition along a tidal gradient. Microhabitats are the number of different seagrass assemblages resulting from small changes in sediment depth following disturbances and reflect species composition and community types dominant for that depth range: Upper $(\mathrm{U})=$ Halodule, Middle $(\mathrm{M})=$ Thalassia/Halodule, Lower $(\mathrm{L})=$ Thalassodenron. 


\section{Tables}

\begin{tabular}{lllllllllllll}
\hline & \multicolumn{1}{c}{ Presence of Seagrass Species } & & \multicolumn{3}{c}{ Shannon } \\
& Ho & Nz & Hu & Th & Cr & Cs & Tc & Si & & $\mathrm{H}^{\prime}$ & $\mathrm{E}_{\mathrm{H}}$ \\
\hline Upper & $*$ & $* *$ & $* * *$ & $* *$ & $* *$ & $*$ & $*$ & $*$ & & 1.47 & 0.71 \\
Middle & $*$ & $* *$ & $* * *$ & $* * *$ & $* * *$ & $* *$ & $* *$ & $*$ & 1.85 & 0.88 \\
Lower & & $*$ & $* *$ & $* * *$ & $* *$ & $* * *$ & $* * *$ & $* *$ & 1.75 & 0.84 \\
\hline
\end{tabular}

Table 2.1. Seagrass species composition and diversity.

The relative importance of individual species along a tidal gradient are listed according to coverage: Infrequent $(*)<5 \%$; common $(* *)=5-30 \%$; frequent $(* * *)>30 \%$. $\mathrm{H}^{\prime}$ is the Shannon Diversity Index with higher numbers representing higher species diversity. EH represents species evenness, where numbers closer to one are considered to have a more even distribution. 


\begin{tabular}{|c|c|c|c|c|c|c|c|}
\hline & & $\mathrm{N}$ & Min-Max & Upper & Middle & Lower & $\begin{array}{l}t \text {-test } \\
p \text { value }\end{array}$ \\
\hline \multirow[t]{2}{*}{ Sediment } & Organic Content ( $\%$ afdw) & 79 & $0.54-5.63$ & $1.41 \pm 0.18$ & $2.00 \pm 0.23$ & $1.36 \pm 0.16$ & 0.096 \\
\hline & Bulk Density $(\mathrm{g} / \mathrm{ml})$ & 79 & $0.43-2.02$ & $1.44 \pm 0.03$ & $1.31 \pm 0.04$ & $1.39 \pm 0.05$ & 0.183 \\
\hline \multirow[t]{2}{*}{ Porewater } & Redox Potential & 79 & $(-143)-84$ & $-83.5 \pm 40.2$ & $-29.8 \pm 12.6$ & $-5.4 \pm 24.3$ & 0.119 \\
\hline & $\mathrm{pH}$ & 79 & $7.3-8.2$ & $7.8 \pm 0.05$ & $7.7 \pm 0.06$ & $7.6 \pm 0.12$ & 0.459 \\
\hline \multirow[t]{3}{*}{ Abiotic } & Depth at MLW (cm) & 305 & & $0 \pm 0$ & $4.32 \pm 0.19$ & $19.2 \pm 0.9$ & \\
\hline & Air Exposure (d / mo.) & & & 28 & 16 & 7 & \\
\hline & $\begin{array}{l}\text { Temperature (min- } \\
\max ^{0} \mathrm{C} \text { ) }\end{array}$ & 3 & & $10.8-46.5$ & $12.9-42.3$ & $15.4-42.4$ & \\
\hline Seagrass & Total Nitrogen (\% dw) & 43 & $1.3-3.6$ & $2.62 \pm 0.1$ & $2.98 \pm 0.1$ & $2.45 \pm 0.2$ & 0.004 \\
\hline \multirow[t]{2}{*}{ Nutrients } & Total Phosphorus (\% dw) & 43 & $0.14-0.31$ & $0.20 \pm 0.01$ & $0.23 \pm 0.01$ & $0.22 \pm 0.01$ & 0.419 \\
\hline & $N: P$ & 43 & $12.5-38.7$ & $29.5 \pm 2.9$ & $29.5 \pm 0.8$ & $26.1 \pm 3.2$ & 0.341 \\
\hline
\end{tabular}

Table 2.2. Descriptive data on abiotic parameters collected at survey sites with seagrass present. Seagrass nutrients are from leaf tissues of Thalassia testudinum. 


\begin{tabular}{|c|c|c|c|c|}
\hline \multirow{2}{*}{$\begin{array}{c}\text { Disturbance } \\
\text { Size (m } \\
\text { width) }\end{array}$} & \multirow{2}{*}{$\begin{array}{c}\text { Disturbance } \\
\text { Type }\end{array}$} & \multicolumn{3}{|c|}{$\begin{array}{c}\text { Mean Number of Individual Disturbances } \\
\text { Intertidal Zone }\end{array}$} \\
\hline & & Upper & Middle & Lower \\
\hline \multirow[t]{3}{*}{$<0.25 \mathrm{~m}$} & Burial & $50.5 \pm 19.3$ & $15.75 \pm 3.3$ & $2.9 \pm 1.7$ \\
\hline & Removal & $10.8 \pm 4.4$ & $15.1 \pm 2.1$ & $3.2 \pm 1.1$ \\
\hline & Other & 0 & $.12 \pm 0.09$ & 0 \\
\hline \multirow[t]{3}{*}{$0.25-0.5 \mathrm{~m}$} & Burial & $3.6 \pm 1.5$ & $5.0 \pm 0.8$ & $2.1 \pm 1.2$ \\
\hline & Removal & $2.5 \pm 0.8$ & $5.0 \pm 1.0$ & $2.5 \pm 1.1$ \\
\hline & Other & 0 & $0.04 \pm 0.04$ & 0 \\
\hline \multirow[t]{3}{*}{$0.5-1 \mathrm{~m}$} & Burial & $2.4 \pm 0.6$ & $2.0 \pm .4$ & $1.0 \pm 0.7$ \\
\hline & Removal & $1.7 \pm 0.4$ & $2.79 \pm .7$ & $2.2 \pm 0.9$ \\
\hline & Other & 0 & $0.04 \pm 0.04$ & 0 \\
\hline \multirow[t]{3}{*}{$1-5 m$} & Burial & $0.5 \pm 0.3$ & $0.3 \pm 0.2$ & 0 \\
\hline & Removal & $1.0 \pm 0.5$ & $1.1 \pm 0.4$ & $0.2 \pm 0.2$ \\
\hline & Other & 0 & $0.04 \pm 0.04$ & 0 \\
\hline \multirow[t]{3}{*}{$>5 \mathrm{~m}$} & Burial & $0.3 \pm 0.213$ & $0.2 \pm 0.1$ & $0.3 \pm 0.2$ \\
\hline & Removal & $0.7 \pm 0.3$ & $0.5 \pm 0.2$ & $0.2 \pm 0.1$ \\
\hline & Other & 0 & 0 & 0 \\
\hline
\end{tabular}

Table 2.3. Mean number of disturbances per site based on size classes and disturbance type for each intertidal zone.

'Other' indicates a cleared area that does not vary in sediment depth with surrounding seagrass area. Values are mean \pm se for using a $180 \mathrm{~m}^{2}$ transect at each site. $\mathrm{N}=44$ sites total, 10 sites for Upper 24 sites for Middle, and 10 sites for Lower intertidal zones. 


\section{Appendix}

\begin{tabular}{lllllllll}
\hline \multirow{2}{*}{ Community Type } & \multicolumn{7}{c}{ Seagrass Species } \\
& Nz & Hal & Th & Cr & Cs & Tc & Si & Ho \\
\hline N. capensis & $* * *$ & $* *$ & $* *$ & $*$ & $*$ & & & \\
H. uninervis - N. capensis & $* * *$ & $* * *$ & $* *$ & $* * *$ & & & & \\
H. uninervis & $*$ & $* * *$ & $* *$ & $* *$ & $* *$ & $*$ & $*$ & $*$ \\
T. hemprichii - H. & & & & & & & & \\
uninervis & $*$ & $* * *$ & $* * *$ & $* *$ & $*$ & $*$ & $*$ & $*$ \\
T. hemprichii & $* *$ & $* *$ & $* * *$ & $* *$ & $*$ & $*$ & $*$ & $*$ \\
C. rotundata & & $* *$ & $* *$ & $* * *$ & $*$ & & $*$ & \\
C. serrulata & & $* *$ & $* *$ & $* *$ & $* * *$ & $*$ & $*$ & \\
T. ciliatum & $*$ & $*$ & $* *$ & $*$ & $*$ & $* * *$ & $*$ & \\
S. isoetifolium & & $* *$ & $* *$ & $*$ & $* *$ & $*$ & $* * *$ & $*$ \\
\hline
\end{tabular}

Appendix 2.1. Species composition found in each mixed seagrass community type, where $* * *=$ dominant $(>50 \%$ cover $), * *=$ common $(5-50 \%$ cover $)$, and $*=\operatorname{sparse}(<5 \%$ cover). $\mathrm{N}=305$ sites. 


\begin{tabular}{|c|c|c|c|c|c|c|c|c|c|c|c|c|c|c|c|c|c|}
\hline & \multirow[t]{2}{*}{$\begin{array}{c}\text { Intertidal } \\
\text { Zone }\end{array}$} & \multicolumn{2}{|c|}{$\begin{array}{l}\text { Thalassodenron } \\
\text { ciliatum }\end{array}$} & \multicolumn{2}{|c|}{$\begin{array}{c}\text { Thalassia } \\
\text { hemprichii }\end{array}$} & \multicolumn{2}{|c|}{$\begin{array}{c}\text { Haodule } \\
\text { uninervis }\end{array}$} & \multicolumn{2}{|c|}{$\begin{array}{c}\text { Cymodocea } \\
\text { serrulata }\end{array}$} & \multicolumn{2}{|c|}{$\begin{array}{l}\text { Cymodocea } \\
\text { rotundata }\end{array}$} & \multicolumn{2}{|c|}{$\begin{array}{l}\text { Syringodium } \\
\text { isoetifolium }\end{array}$} & \multicolumn{2}{|c|}{$\begin{array}{c}\text { Nanozostera } \\
\text { capensis }\end{array}$} & \multicolumn{2}{|c|}{ Halophilia ovalis } \\
\hline & & Mean & $\mathrm{SE}$ & Mean & $\mathrm{SE}$ & Mean & $\mathrm{SE}$ & Mean & $\mathrm{SE}$ & Mean & $\mathrm{SE}$ & Mean & $\mathrm{SE}$ & Mean & SE & Mean & $\mathrm{SE}$ \\
\hline Total & Upper & & & 2.62 & 0.1 & 2.54 & 0.17 & & & 2.97 & 0.15 & & & 2.42 & 0.23 & & \\
\hline \multirow[t]{2}{*}{ Nitrogen } & Middle & 1.71 & 0.05 & 2.98 & 0.05 & 2.22 & 0.04 & 1.88 & 0.06 & 2.97 & 0.1 & 1.54 & 0.11 & 1.91 & 0.07 & 2.23 & 0.17 \\
\hline & Lower & 1.73 & 0.15 & 2.45 & 0.23 & 2.24 & 0.09 & 2.24 & 0.11 & 2.69 & 0.24 & 1.52 & 0.21 & & & & \\
\hline Total & Upper & & & 0.2 & 0.01 & 0.24 & 0.02 & & & 0.19 & 0 & & & 0.29 & 0.03 & 0.33 & 0.03 \\
\hline \multirow[t]{2}{*}{ Phosphorus } & Middle & 0.22 & 0.01 & 0.23 & 0.01 & 0.26 & 0.01 & 0.28 & 0.01 & 0.25 & 0.01 & 0.2 & 0.01 & 0.22 & 0.01 & & \\
\hline & Lower & 0.21 & 0.02 & 0.22 & 0.01 & 0.24 & 0.02 & 0.28 & 0.01 & 0.23 & 0.01 & 0.18 & 0.01 & & & & \\
\hline \multirow[t]{3}{*}{$\mathrm{C}: \mathrm{N}$} & Upper & & & 18.7 & 0.5 & 20.8 & 1.2 & & & 18.4 & 0.6 & & & 20.3 & 1.6 & 17.5 & 1.9 \\
\hline & Middle & 30.3 & 0.7 & 16.9 & 0.3 & 22.6 & 0.4 & 26.2 & 0.8 & 17.9 & 0.5 & 25 & 0.9 & 26.1 & 0.9 & & \\
\hline & Lower & 30.5 & 2.4 & 20.4 & 1.6 & 22.8 & 1 & 22.3 & 1.1 & 19.6 & 1.5 & 28 & 2.4 & & & & \\
\hline \multirow[t]{3}{*}{$C: P$} & Upper & & & 551 & 52 & 501 & 47 & & & 649 & 29 & & & 384 & 35 & 260 & 14 \\
\hline & Middle & 534 & 32 & 499 & 19 & 439 & 15 & 395 & 19 & 453 & 18 & 416 & 16 & 505 & 18 & & \\
\hline & Lower & 571 & 88 & 498 & 44 & 481 & 40 & 395 & 22 & 501 & 7 & 504 & 30 & & & & \\
\hline \multirow[t]{3}{*}{$N: P$} & Upper & & & 29.5 & 2.9 & 23.9 & 1.4 & & & 35.5 & 2.8 & & & 18.9 & 0.7 & & \\
\hline & Middle & 17.9 & 1.5 & 29.5 & 0.8 & 19.5 & 0.6 & 15.3 & 1 & 25.5 & 0.9 & 16.8 & 0.9 & 19.6 & 0.7 & 15.2 & 2.5 \\
\hline & Lower & 19.4 & 3.7 & 26.1 & 3.2 & 21.3 & 1.8 & 18 & 1.2 & 25.8 & 1.8 & 18.7 & 2.4 & & & & \\
\hline
\end{tabular}

Appendix 2.2. Nitrogen and phosphorus content of seagrass leaves expressed as percentage of dry weight, and nutrient rations expressed as mole:mole. $\mathrm{N}$ values vary by location and species. 

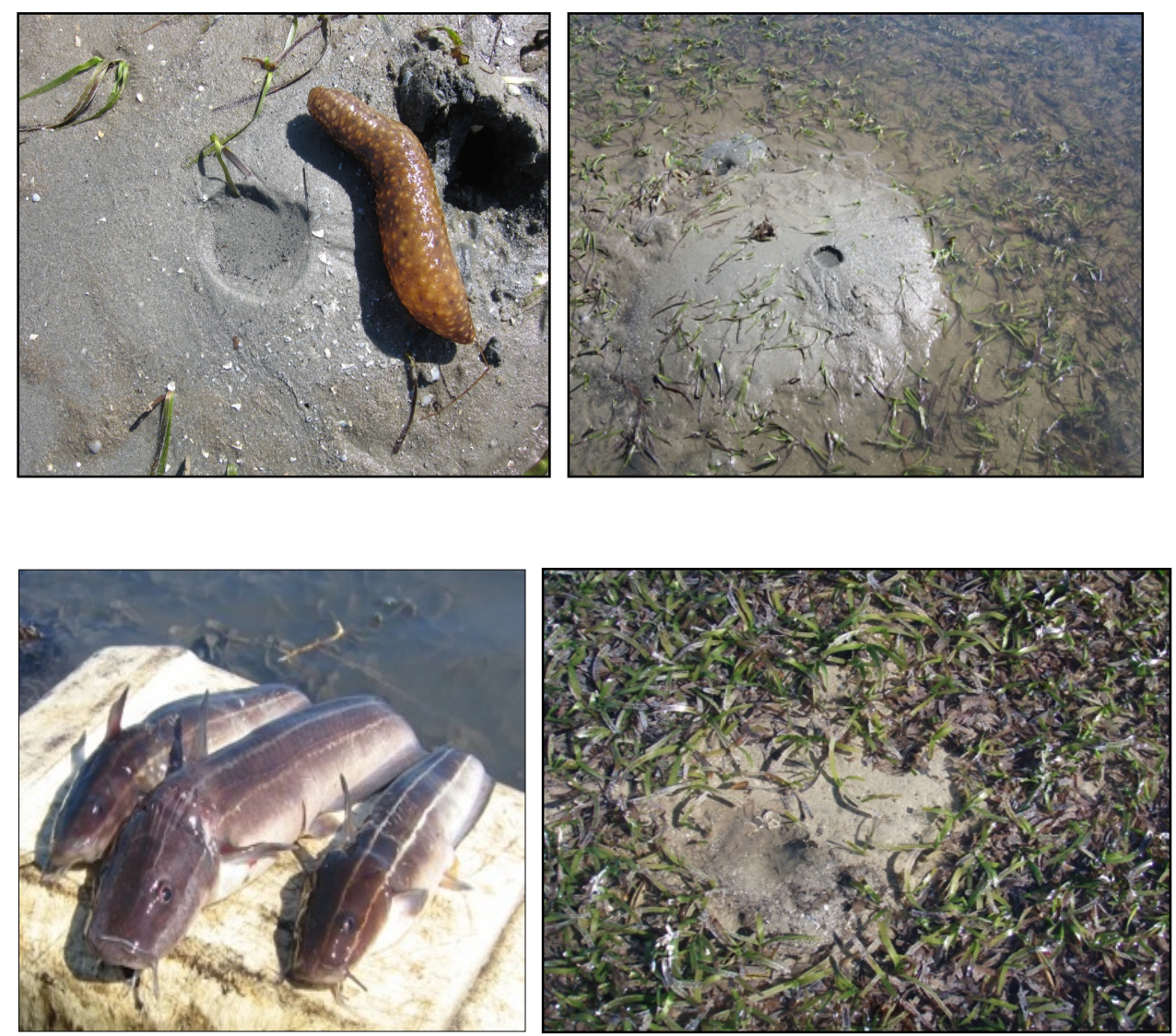

Appendix 2.3. Examples of bioturbation-driven disturbance in seagrass meadows. Above is a mound created by a Holothurian species (sea cucumber). A small round depression is formed at the top of the mound as a result of animal existing the mound to spit out sand. Below is clearing created by the burrowing Conger cinereus cinereus, the Black edged conger eel. 


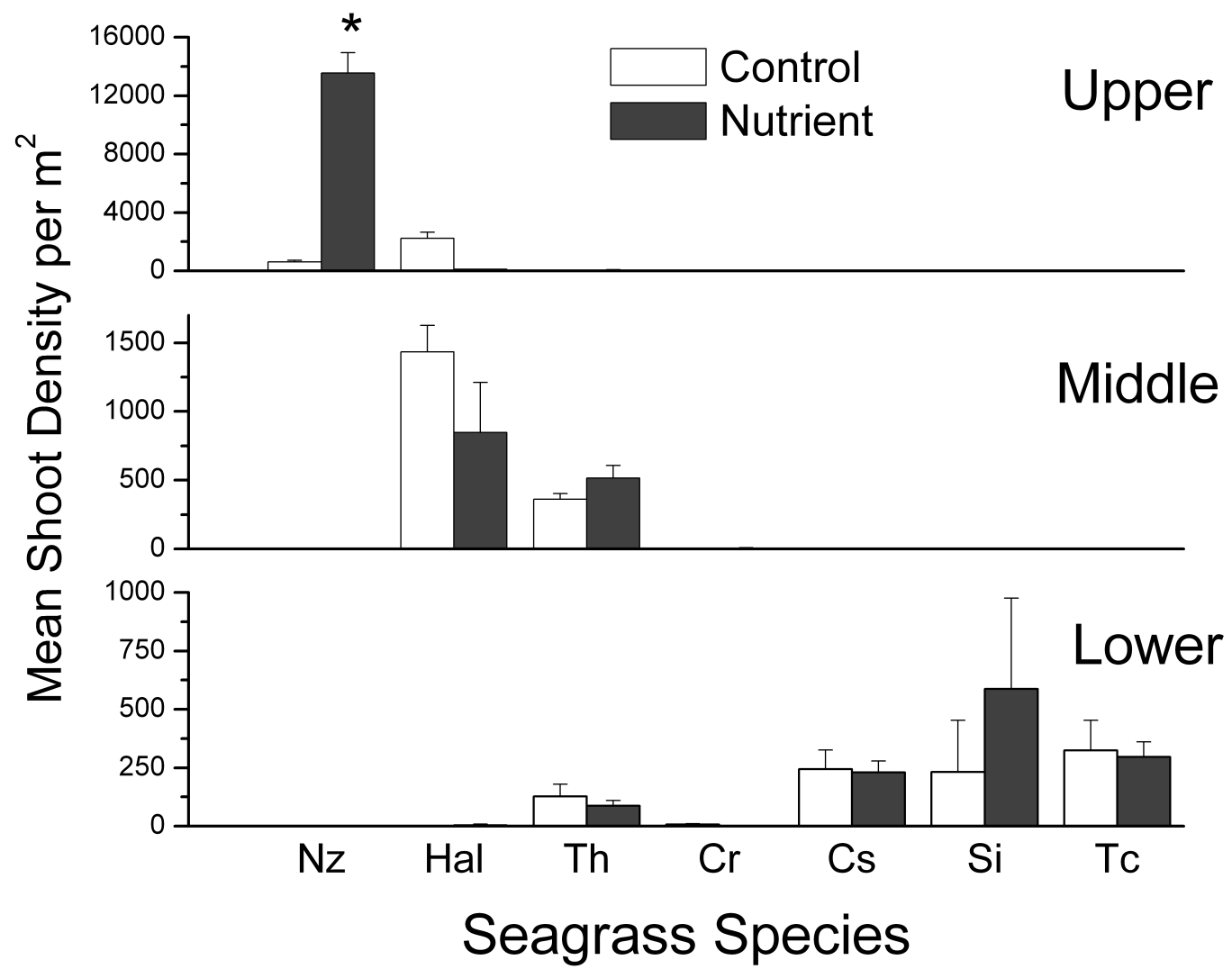

Appendix 2.4a. Mean shoot density for each seagrass species following 20 months of nitrogen and phosphorus enrichment at the three intertidal sites. Where species are present, $\mathrm{n}=6$ plots each for nutrient enriched treatments and non-enriched control plots. Error bars are $+1 \mathrm{SE}$; $\mathrm{a} *$ indicates significance of $p<0.05$. 


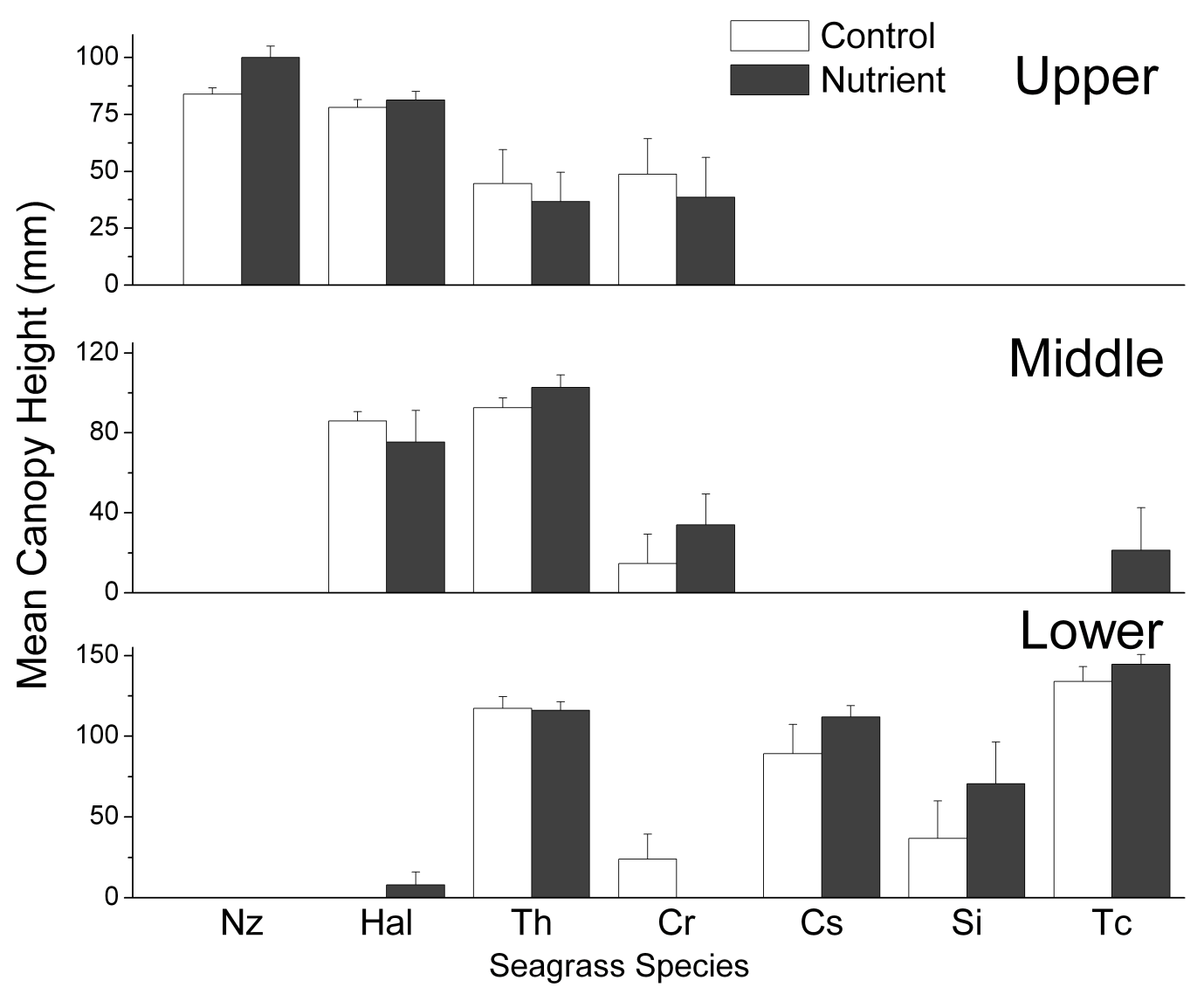

Appendix 2.4b. Mean canopy height (mm) for each seagrass species following 20 months of nitrogen and phosphorus enrichment at the three intertidal sites. Where species are present, $n=6$ plots each for nutrient enriched treatments and non-enriched control plots. Error bars are $+1 \mathrm{SE} ; \mathrm{a} *$ indicates significance of 


\title{
Chapter Three: Disturbance type and tidal placement affect recovery patterns of soft-bottom marine plant communities
}

\begin{abstract}
The influence of small-scale disturbances on seagrass structure (density, species composition) and ecosystem attributes (sediment characteristics, primary production, fauna abundance and diversity) were examined along a tidal gradient in Mozambique, Africa. Natural disturbances that cause both sediment burial and removal were simulated in-situ at 3 intertidal sites (upper, middle, lower) and allowed to recover un-manipulated for 20 months. The resilience (rate of recovery) and trajectory (direction of species replacement) following sediment disturbance varied based on disturbance type and tidal location. Seagrass resilience was highest in the upper intertidal where fast-growing dominant species (Halodule uninervis, Nanozostera capensis) returned to pre-disturbance shoot density levels after 20 months with no difference between burial or removal treatments. Recovery in the lower intertidal was dependent on the type of disturbance: the large-size dominant species (Thalassodenron ciliatum) was able to tolerate sediment burial, but sediment removal resulted in slow recovery due to slow vegetative expansion rates. Following disturbance, most cleared areas were re-colonized by the pre-disturbance species. Only 2 treatments exhibited a change in community structure following disturbance; T. hemprichii increased following sediment removal in the upper intertidal, while the fast-growing Syringodium isoetifolium increased following both sediment
\end{abstract}


burial and removal in the lower intertidal. The later scenario provided the only indication of successional replacement trajectories typically observed for seagrasses, where opportunistic species colonize cleared areas following the removal of larger species.. The middle intertidal did not experience any changes in species composition but recovery rate was slower than was predicted based on similar studies and species-specific growth rates (ca. 30\% shoot density recovered after 20 mo.). This slow recovery may be related to site-specific forces such as localized herbivory pressure on new leaf growth. Slow recovery at the middle intertidal was associated with significant reductions in other ecosystem attributes such as sediment organic content, areal primary production, and fauna abundance. Infauna abundance and diversity did not completely recover in some treatments even when seagrass biomass returned to pre-disturbance levels, suggesting that the return of ecosystem functions such as habitat utilization may lag behind plant recovery and that monitoring of above-ground plant components is not an accurate indication of full community recovery. This study reveals how seagrass recovery following disturbance in mixed-species intertidal meadows is complex, and that recovery prediction using simple seagrass succession models is limited and should incorporate specific disturbance types and tidal placement. The importance of sediment elevation in determining community composition following a disturbance is a novel and key mechanism that adds a three dimensional component to seagrass succession models. These findings can be applied to our general understanding of disturbance resilience and recovery at the community scale and to restoration efforts in tropical seagrass ecosystems throughout the world. 


\section{Introduction}

Disturbances have long been recognized as a crucial driver of population and community structure in many systems (see Pickett and White, 1985 for review). Seagrass communities are composed of marine angiosperms that inhabit soft-bottom sediments and are ideal candidates for studying ecological disturbance and recovery. Their rapid expansion rates compared to many terrestrial plants allow for the observation of community change in a relatively short time frame. Also, the location of seagrasses in shallow coastal systems throughout the world (McRoy and McMillan 1977) and their proximity to shorelines increases susceptibility to a variety of natural and anthropogenic disturbances that vary in size, timing and intensity (Short and Wyllie-Echeverria 1996).

Numerous types of physical and biological disturbances are known to impact seagrasses, Natural disturbances storm events (Fourqurean and Rutten 2004) and bioturbation activity (Valentine et al. 1994, Townsend and Fonseca 1998). Anthropogenic physical disturbances have contributed to the global loss of seagrass habitat in recent years (Waycott et al. 2009) and include propeller scarring (Zieman 1976, Kenworthy et al. 2002, Martin et al. 2008), anchor and mooring placement (Walker et al. 1989, Creed and Amado 1999, Ceccherelli et al. 2007), boat groundings (Fonseca et al. 2004, Kirsch et al. 2005), dredging (Erftemeijer and Lewis 2006), and human trampling (Eckrich and Holmquist 2000). 
The impacts of disturbances vary considerably in size, from relatively small anchor scars less than a meter wide, to vessel groundings containing depressions several meters deep and extending up to thousands of square meters (Whitfield et al. 2002). These disturbances create openings within the vegetated environment that is analogous to that of light gaps created by tree falls in forests(Oldeman 1978), lightning strikes in mangroves (Sherman et al. 2000), or badger mounds in grasslands (Platt 1975). When a bare patch is created by the disturbance, resources such as light and space are made available for new species recruitment. Regular disturbance activity leads to a shifting mosaic of patches across the landscape, each at different stages of recovery (Watt 1947, Pickett and White 1985).

Prevailing theory regarding seagrass recovery following disturbance borrows heavily from the facilitation model of succession. This model suggests that recently disturbed areas are first colonized by pioneer species, whose presence modifies the site in a way that increases the suitability for other species. One established these later-succession species eventually eliminate the early succession species. The most commonly accepted succession model for Caribbean seagrasses is initial colonization by calcareous green macroalgae and fast growing seagrasses (Halodule wrightii, Syringodium filiforme) followed by the replacement of the late-successional Thalassia testudinum This model has been developed based on the propensity for T. testudinum to dominate macrophyte communities in the Caribbean (den Hartog 1971), and is supported by studies that 
examined recolonization patterns after natural disturbances (Patriquin 1975), as well as those that experimentally removed vegetation (Williams 1990, Kenworthy et al. 2002).

Succession models in Indo-Pacific seagrass communities are likely to be more complex due to the larger number of species with unique life history traits such as growth form and colonizing ability. Three common species are found in the Caribbean, where as up to 14 species can be found co-existing in dense shallow meadows of the Indo-Pacific (Short et al. 2007). Indo-Pacific meadows also tend to be mixed species (Vermaat et al. 1995) compared to the Caribbean that is dominated by monospecific meadows of T. testudinum (Zieman 1982). Finally, many Indo-Pacific seagrass communities are found in intertidal zones that have natural gradients of exposure stress compared to Caribbean communities that are mostly subtidal.

Small-scale disturbances have been suggested as one factor that promotes the relatively high species co-existence and local diversity of seagrasses (Duarte et al. 1997), and the role of these types of disturbance on landscape dynamics is often overlooked (Bell et al. 1999). Previous investigations have documented species-specific responses of IndoPacific seagrasses to two different types of small-scale disturbances; smothering of plant material by sediment burial or by the excavation and removal of the plants and sediment (see Cabaco et al., 2008 for review). These studies did not explicitly examine the differences along a tidal gradient and none have examined effects of disturbance on additional community components such as sediment characteristics and fauna 
composition. The number of possible recovery trajectories may increase in the intertidal zone because slight changes in water depth can either inhibit or facilitate the survival of certain species, thus resulting in new species combinations that differ from the original seagrass assemblages. Recovery rates and trajectories can also be affected by a variety of sediment characteristics that can change following disturbances including depth, oxygen, nutrients and substrate type (Zieman 1976) (Kenworthy and Fonseca 1992). Finally, little attention has been placed on how community development following disturbance can affect vital ecosystem functions such as habitat utilization by fauna.

Predicting how seagrasses respond to disturbance has been listed as a top conservation priority (Duarte 2002). This task is further complicated in the Indo-Pacific as there exists a general lack of knowledge regarding seagrass biology and ecology in this region as compared to the well-studied temperate and Caribbean counterparts (Duarte 1999). This is especially true for seagrasses in East Africa and elsewhere in the Western Indian Ocean (Gullstrom et al. 2002). We do not have the knowledge to predict how multi-species seagrass communities in the Indo-Pacific recover from different types of disturbance along a tidal gradient or how these disturbances influence other ecosystem functions such as habitat utilization by fauna. The goal of this study was to determine the response of species-rich Indo-Pacific seagrass communities to small-scale discrete disturbances that are common occurrences in shallow seagrass meadows (e.g., boat scars, bioturbation, storm events). This was done with a 20 -month in situ field experiment using different disturbance types and tidal locations. The specific objectives were to (1) determine how 
small-scale disturbance affect habitat structure (seagrass cover and composition) and ecosystem attributes (sediment characteristics, plant primary production, fauna abundance and diversity, and (2) assess how does disturbance resilience, defined as the rate of recovery to the pre-disturbed state, vary based on disturbance type (sediment burial and removal) and location along the tidal gradient.

\section{Methodology}

\section{Study Site}

This study was conducted off the east coast of southern Mozambique on Inhaca Island $\left(25^{\circ} 58^{\prime}\right.$ and $26^{\circ} 05^{\prime} \mathrm{S}, 32^{\circ} 55^{\prime}$ and $33^{\circ} 00^{\prime} \mathrm{E}$ ) (Figure 3.1). Although the island is in the sub-tropics, the warm water of the Mozambique Current creates tropical conditions and most of the organisms are the same as in the tropical Indo-West Pacific Region (1995). Seagrasses cover approximately $50 \%$ of the Inhaca intertidal zone along the ca. $60 \mathrm{~km}^{2}$ shoreline, which has a tidal amplitude of 0.1 to $3.9 \mathrm{~m}$. Inhaca has a high diversity of subtropical and tropical species of seagrass with eight species found in three families: Cymodocea rotundata, Cymodocea serrulata, Halodule uninervis, Halophila ovalis, Nanozostera capensis, Syringodium isoetifolium, Thalassodendron ciliatum, and Thalassia hemprichii. 


\section{Experimental Design}

A manipulative disturbance experiment was conducted to assess the response of the sediment, plant and fauna components of the seagrass community along an intertidal gradient. Intertidal was defined as areas where seagrass leaves are at least partially exposed to air at mean low water. Three distinct seagrass intertidal zones exist along the intertidal gradient and can be defined based on standing water depth at mean low tide, frequency of air exposure (days/month), and dominant seagrass assemblages. These zones are the Upper intertidal (0 cm standing water, exposed ca. 28 days, Halodule uninervis dominant or un-vegetated), Middle intertidal (1-10 $\mathrm{cm}$ standing water, exposed ca. 16 days, Thalassia hemprichii dominant), and Lower intertidal (10-30 cm standing water, exposed ca. 7 days, Thalassodendron ciliatum dominant). Experimental sites were selected using criteria that a) would characterize different environmental conditions typical of a tidal gradient, and b) best represent the three dominant seagrass communities on Inhaca Island (Paula et al. 2001, Bandeira 2002), as well as assemblages common to the West-Indian Ocean (Figure 3.2). Adjacent sites that met these requirements and represented the three zones could not be located due to the high heterogeneity of the shoreline, the space requirement for the experiment, and our restriction to the small protected conservation areas that excluded local harvesting practices in seagrass meadows. The middle and lower intertidal sites were located on Portuguese Island, a small island located $2 \mathrm{~km}$ offshore of Inhaca in the sheltered Maputo Bay. Seagrass plant size and abundance increased with depth, with $T$. hemprichii and a larger variant of $H$. uninervis dominating the middle intertidal (ca. $75 \%$ cover) and T. ciliatum and $C$. 
serrulata at the lower intertidal (ca. 100\% cover). Each intertidal site had at least 5 species present. The upper intertidal site was located on a southern bank with moderate abundance (ca. 50\% cover) of small stature species such as H. uninervis. Although this site was not adjacent to the middle and lower sites, it was selected because it included the highest continuous seagrass meadow delineating an upper tidal zone. This site resembled upper intertidal sites adjacent to the middle and lower sites with respect to sediment, plant and animal composition, in addition to hydrological (tidal amplitude and source) and biogeochemical (seagrass and sediment nutrients) regimes (Muth, unpublished data).

Sediment burial and excavation were selected as disturbance treatments because each reflect naturally occurring disturbances such as storm events and bioturbation. The effects of these two physical actions on seagrass differs; burial smothers the leaves without altering the belowground biomass, and excavation removes all above and belowground plant material. At each of the three sites, 6 replicates of the 3 treatments (Control, Removal, Burial) were applied randomly to a grid of $0.25 \mathrm{~m}^{2}$ permanent plots with $2.5 \mathrm{~m}$ of separation between each plot, for a total of 54 plots in this experiment (Figure 3.3). A one-time removal or addition of $10 \mathrm{~cm}$ of sediment was applied to each disturbance treatment. The disturbance treatment size and depth was ecologically relevant and based on mean disturbance width and depth recorded during a preliminary intertidal survey of 405 sites around the island (Chapter 2). In order to mimic localized natural disturbances, sediment used for Burial treatments was collected from the closest adjacent unvegetated area. 


\section{Sampling Procedures}

The experiment lasted 20 months, beginning in December 2005 and terminating in July 2007. Sampling times were chosen to emphasize initial changes in the first 2 months and thereafter to capture seasonal changes. Sampling was done before treatment application and throughout the experiment at 1, 2, 5, 7, 10, 15, and 20 months. Sediment deposition and erosion rates of each intertidal site were measured during each sampling event using 20 small (0.5 cm diameter) labelled PVC sticks inserted into the sediment that were distributed throughout the sampling grid at least $1 \mathrm{~m}$ from a permanent plot. No accumulation or erosion was observed around these sticks, which suggests that this protocol for estimating sedimentation had no significant effect on local hydrodynamics.

Response variables were selected to describe the sediment, plant and faunal components in a non-destructive way. Seagrass parameters measured during each sampling time were species-specific shoot density, canopy height ( $80 \%$ of tallest leaf) and visible sexual seagrass output (flowers, fruits, seeds). Macro-fauna on the surface were recorded at each sampling time. Effects of disturbance on the infaunal community were determined by collecting one sediment core $(0.25 \mathrm{~m} \times 0.25 \mathrm{~m})$ in each plot at the end of the experiment in order to avoid disruption of the plots during the study. Cores were sieved $(1 \mathrm{~mm})$ and fauna were sorted, counted and identified to the lowest possible taxonomic level. Live seagrass material in 4 of the 6 cores from each treatment was separated by species and below- versus above-ground components, rinsed, dried, and weighed to calculate 
biomass. Seagrass community-scale growth rates were calculated by multiplying leaf growth rate (g dw/ss/d) with mean shoot density for each species and summing all species together. Leaf growth rate was calculated as the average rate from 2 years of bi-annual growth measurements using a modified hole-punch technique. Sediment height in every plot was measured each sampling time relative to the surrounding area. Sediment cores for each plot were collected $(10 \mathrm{cc}, 1.35 \mathrm{~cm}$ id, $3 \mathrm{~cm}$ depth), dried, homogenized, and ashed at $500{ }^{0} \mathrm{C}$ for 6 hours to determine \% loss on ignition for sediment organic content.

\section{Statistical Analyses}

Seagrass and sediment parameters sampled repeatedly throughout the experiment were analyzed using repeated measures ANOVA with Time as a categorical within-subject factor and intertidal Site and Disturbance type as between-subjects factors. When Mauchly's tests indicated that assumptions of sphericity were violated, corrections were made using Huynh-Feldt estimates of sphericity. Differences in environmental characteristics between sites were determined with univariate ANOVA tests. The effects of disturbance type (Burial, Removal) on seagrass shoot density and on fauna parameters (abundance, species richness, diversity) were tested at the end of the experiment using univariate ANOVA for site mean values. Data were transformed to meet the assumptions of ANOVA prior to analysis. If the main ANOVA was significant, Tukey's post-hoc comparison test was used to identify differences between disturbance treatments. If sample variances differed, then the Games-Howell test was used instead. Means were 
statistically significant at $p \leq 0.05$. Faunal diversity was determined using Shannon's Diversity index (Shannon, 1948).

\section{Results}

\section{Site Characteristics}

The three intertidal sites differed in physical, chemical and biological parameters (Table 1.1). Seagrass leaf exposure during low tides ranged from nearly every day at the upper site to only one week per month at the lower intertidal site. Mean standing water depth at MLW ranged from $25 \mathrm{~mm}$ (upper) to $75 \mathrm{~mm}$ (lower), although it was not uncommon for the middle and upper intertidal meadows to be briefly exposed completely during a spring low tide. Water temperature means collected by sensors ca. $5 \mathrm{~cm}$ above the sediment were similar between sites and the upper intertidal had the largest range (10.8 $46.5^{0} \mathrm{C}$ ). Sediment grain size increased along the gradient, with the lower intertidal site having the coarser sand. Annual sedimentation rates were lowest at the upper intertidal, and largest at middle intertidal. Sediment nutrient means differed between sites, where nitrogen was significantly lower at the upper intertidal $\left(\mathrm{F}_{2,15}=8.94, p=0.003\right)$, and phosphorus was significantly higher at the lower intertidal $\left(\mathrm{F}_{2,15}=13.433, p<0.001\right)$. Organic content was not significantly different between sites. Seagrass cover and plant size increased with depth, where the upper intertidal was dominated by Halodule uninervis / Nanozostera capensis, the middle intertidal by Thalassia hemprichii / $H$. 
uninervis, and the lower intertidal by Thalassodendron ciliatum / Cymodocea serrulata / T. hemprichii.

\section{Sediment}

Recovery of sediment depth to pre-disturbance levels following Removal and Burial varied between both sites and treatments (Figure 3.4). Sediment levels at the upper and middle intertidal returned to pre-disturbance levels within 7 months regardless of treatment application. There was a difference in sediment depth recovery between treatments at the lower intertidal; the Burial treatment recovered immediately while the Removal treatment required approximately 1 year. Sediment organic content (SOC) recovery also varied depending on site (Figure 5). The SOC in the upper and lower intertidal returned to original values almost immediately. A significant SOC decrease from pre-disturbance levels was observed at the middle intertidal 20 months after disturbance for both Burial $\left(\mathrm{F}_{1,10}=4.196, p=0.068\right)$ and Removal $\left(\mathrm{F}_{1,10}=6.157, p=0.032\right)$.

\section{Seagrass}

Disturbance treatments led to initial seagrass mortality of all seagrass at most sites, but the time and direction of recovery varied according to site and treatment (Figure 3.6). Full recovery to pre-disturbance seagrass shoot density at the upper intertidal was reached for both the Burial and Removal treatments towards the end of the experiment. The only significant effect of disturbance at the upper intertidal was an increase in T. testudinum, a 
minor constituent of the assemblage, following Removal $(p=0.013)$. Middle intertidal plots exhibited the slowest recovery, with less than $50 \%$ of the seagrass shoots returning to original density levels. The two dominant species at the middle intertidal, $T$. hemprichii and H. uninervis, remained significantly lower than control plots in both Burial and Removal treatments, even after 20 months (Figure 3.7). Although no significant treatment effects were found at the lower intertidal, there was a trend of increasing shoot densities for the faster growing and smaller stature $S$. filiforme, especially in the Removal treatment. Total seagrass biomass (Figure 3.8) decreased in both Burial and Removal treatments relative to Control at middle intertidal $(p=0.012)$. Total new biomass production for all species combined, as indicated by seagrass areal productivity (Figure 3.8), showed a significant decrease in disturbance treatments at middle intertidal $(p=0.001)$. There was no observed influence of sexual reproduction on recovery in the form of seedling colonization.

\section{Fauna}

Fauna identified in this study consisted of a total of 7 phyla, 57 families and 95 species, which is similar to results from other surveys on Inhaca ([NO STYLE for: Nordlund 2006])(complete list in Appendix 3.2). Community composition varied considerably between sites; holothurians were the most common taxa encountered in the upper intertidal, while bivalves and polychaetes dominated the middle and the lower intertidal (Figure 3.2). Trends of total abundance (number of individuals) and species richness (number of species) 20 months after disturbance were similar (Figure 3.9, Table 3.3). 
Effects of disturbance on community composition differed according to site and treatment. Species richness from both upper intertidal Burial and Removal treatments were not significantly different from controls at the end of the experiment. Removal treatments did show a decrease in diversity and evenness due to a loss of holothurians and a greater contribution of polychaetes. Disturbance treatments in both the middle and lower intertidal resulted in decreased total species abundance (middle $p=0.008$, lower $p=0.004$ ) and species richness (middle $p=0.014$, lower $p=0.033$ ). Fauna diversity, as measured by Shannon's Diversity Index H', was drastically reduced in both Burial (0.39) and Removal (0.00) disturbance treatments in the middle intertidal relative to the control (9.36). Evenness values $\left(\mathrm{e}^{\mathrm{H}^{\prime}}\right)$ mirrored diversity patterns. To evaluate what organisms were most responsible for community composition changes, specific analyses were conducted on the 3 most common taxonomic groups encountered; polychaetes, crustaceans and molluscs. Only the molluscs decreased significantly with both Burial and Removal disturbance treatments at the middle $(p=0.006)$ and lower $(p=<0.001)$ intertidal sites. The mollusc community remained negatively affected at the lower intertidal, despite the return of total above and belowground seagrass biomass to predisturbance levels (Figure 3.8). A decrease in overall diversity in upper intertidal Removal treatments, was attributed to the loss of holothurians and increase in polychaetes. 


\section{Discussion}

This study demonstrates that seagrass community recovery following disturbance can be complex, with both the type of disturbance and location along the tidal gradient affecting the trajectory and speed of seagrass recovery.

\section{Disturbance Resilience as a function of life history strategies and plant morphology}

The upper intertidal had the highest resilience (rate of recovery) of all sites to both sediment Burial and Removal disturbances and returned to the pre-disturbance shoot density levels by the end of the 20 mo. experiment. These upper intertidal zones are dominated by smaller species with rapid clonal expansion rates, and are characterized by more frequent natural disturbances such as bioturbation as compared to the middle and lower intertidal zones (Chapter 2). While such high disturbance pressure may select preferentially for opportunistic fast-growing species that are adapted to early succession environments (Huston 1994), exposure stress likely exerts a stronger role in determining species composition in the upper intertidal (Chapter 2). The dominant upper intertidal $H$. uninervis is able to persist because of physiological and morphological plant adaptations to deal with desiccation and direct UV radiation (Bjork et al. 1999, Peralta et al. 2005, Shafer et al. 2007).

In contrast to the upper intertidal where there was no difference between Burial or Removal treatments, sites dominated by larger slower-growing species in the middle and 
lower intertidal were sensitive to the specific nature of the disturbance, with high resilience to Burial and low resilience to Removal. These slow-growing plants (i.e. $T$. ciliatum) have considerably more aboveground and belowground biomass which allows it to survive and re-emerge after burial events (Duarte et al. 1997). While the large size of the plant can increase its resistance to sediment burial events, the slower growth rates associated with these larger plants may decrease resilience to sediment removal. The larger plants that dominate in deeper zones allocate a large amount of biomass to belowground root and rhizome structures needed to support the large aboveground structure. The loss of this biomass during sediment excavation and the slower rates of rhizome elongation contribute to the reduced recovery rate, as observed when T. ciliatum reached less than $50 \%$ of pre-disturbance density levels one year following sediment removal (Figure 3.6).

Other community components besides plant growth traits may influence recovery speed. The slowest rates of sediment depth recovery were found for sediment removal plots in the lower intertidal. The persistence of deep depressions can limit the horizontal expansion of slow growing species into these bare gaps, and may also be more vulnerable to additional disturbances such as storm events that can increase erosion (Kenworthy et al. 2002). It was also not uncommon to find large amounts of seagrass detritus accumulating in these pits and remaining trapped for several months, which may further prevent sediment filling of the excavations and delay seagrass colonization by smothering new shoots (Holmquist 1997). Therefore, the large above- and belowground plant size of 
T. ciliatum is both an attribute (rapid recovery to Burial) and detriment (slower recovery to Removal) to disturbance resilience. This finding highlights the importance of disturbance type when predicting species-specific recovery outcomes.

\section{Changes in Plant Community Composition}

Most disturbed plots demonstrated some degree of resilience by returning to the initial plant community composition. However, there were two treatments that exhibited signs of changes in species composition and these two changes may be attributed to separate mechanisms. First, a four-fold increase in T. hemprichii shoot density was observed following sediment Removal in the upper intertidal. Sediment removal increased the standing water at low tide and that may have alleviated exposure stress sufficiently to promote the expansion of $T$. hemprichii. This supports the notion that very small changes $(\mathrm{mm})$ in micro-topography can significantly affect patterns of species distributions in the intertidal zone (Bandeira 2002)(Chapter 2). Elevated sediment mounds are naturally found throughout the seagrass intertidal zone (Chapter 2), and most of these mounds have no vegetation because of increased exposure time that is beyond the tolerance range for seagrasses. The lack of an effect of sediment burial treatment in the upper intertidal may be related to our one-time application of the disturbance, which does not replicate the continual bioturbation activity (Figure 3.11). The length of bioturbation activity depends on the species, but shrimp burrows typically last several months (Duarte et al. 1997) and some burrows on Inhaca Island persist for over a year (Muth, unpublished data). 
The second indication of a change in species composition was the increased shoot density of the faster-growing species (S. isoetifolium) following the removal of the larger slowgrowing species (T. ciliatum) in the lower intertidal. This was the only example of the traditional seagrass succession model, where a fast growing pioneer species rapidly colonized an area following the removal of a slower growing climax species. Although it was not a statistically significant effect, this trend of enhanced S. isoetifolium density was also observed in studies showing $S$. isoetifolium to increase and maintain its dominance for years when competing species were removed (Duarte et al. 2000, Rasheed 2004). It is possible that we are witnessing the early stages of pre-emptive exploitation (Lubchenco 1980), where faster growing species occupy newly created space and competitively exclude the original climax species from colonizing into the area. This process may be responsible for the persistent presence of small distinct patches of $S$. isoetifolium within expansive T. ciliatum meadows on Inhaca Island (Muth, personal observation). However, it is not clear if this trend will persist and $S$. isoetifolium will replace $T$. ciliatum as the dominant species over time. Syringodium species in the Caribbean reached maximum shoot density three years after disturbances before showing signs of decline (Hammerstrom et al. 2007), which is longer than the 20 months in this study. Ongoing competitive interactions between species illustrates the need to continue monitoring disturbance experiments even after the gap has been filled in because of delayed community responses and potential successional replacement. 
In both of the scenarios of community composition changes mentioned $-T$. hemprichii in the upper intertidal and $S$. isoetifolium in the lower intertidal - these species were relatively minor components of their respective meadow and were patchy in distribution across the experimental grid due to natural heterogeneity. Vegetative expansion opportunities by these species into cleared plots, which the dominant mechanism of gap re-colonization, were not equal for all treatment plots. As a result, the sample size of plots containing these species and associated statistical strength was reduced for these particular effects.

\section{Consumer Control as a Factor in Disturbance Recovery}

The slow recovery at the middle intertidal $(<50 \%)$ was unexpected, as studies have documented faster recovery with similar species composition, experimental design and time scales (Rollon et al. 1998). Sediment conditions were not responsible for this slow rate because the depth and organic content recovered within 7 months. Although mean sedimentation rates were higher at this site compared to others $(0.94 \mathrm{~cm}$ per year $)$, vertical growth patterns of the seagrasses are sufficient to accommodate these rates (Duarte et al. 1997), and young shoots continued to grow in adjacent control plots. Expansion rates of $H$. uninervis, one of two dominant species in the middle intertidal, is sufficient to fully recover within the time and spatial scale of this experiment, and indeed this species did return to pre-disturbance density levels at the upper intertidal. 
One possible explanation for the slow recovery is that external forces, grazing in particular, may be driving the slow recovery. Herbivory pressure on seagrass leaves by urchins and fish were high at this site, as indicated by $\sim 90 \%$ of 416 randomly collected shoots exhibiting some sign of fish or urchin bite marks. Also, total leaf area removed by grazing was significantly higher at the middle intertidal compared to the upper and lower intertidal sites (Appendix 3.3). Grazing pressure has been shown to interact with plant recovery in other systems, such as decreasing survivorship of early successional colonization in salt marsh communities (Ellison 1987) or preferential selection that leads to grassland replacement by shrubland (Anderson and Briske 1995). While high herbivory pressure has been reported in some seagrass systems (Valentine and Heck 1999, Kirsch et al. 2002, Heck and Valentine 2006), the role of grazing in altering the recovery trajectory following disturbance has rarely been examined for seagrass communities. To test whether herbivory may be driving the slow recovery observed at the middle intertidal, we conducted a series of tethering experiments at the middle intertidal in naturally occurring bare gaps and adjacent seagrass patches. Results of the experiments showed significantly higher grazing intensity for seagrass shoots within recently disturbed gaps as compared to surrounding seagrass patches (Appendix 3.3), providing evidence that consumer control may be contributing to the slow recovery of seagrass at the middle intertidal. 


\section{Ecosystem Functions: Primary Productivity and Fauna Habitat Utilization}

This study demonstrates that the recovery of some ecosystem functions following disturbances will vary depending on location and disturbance type. Marine plants such as seagrass contribute a disproportionately high amount of net primary productivity and carbon sequestration compared to their terrestrial counterparts (Nellemann et al. 2009). Lasting effects of small-scale disturbances on seagrass areal primary production was not found, except at the middle intertidal where there was a significant decrease due to the slow return of seagrass biomass. Nursery and habitat roles are an important local ecosystem function provided by seagrass meadows in the West Indian Ocean due to the strong harvesting pressure by local human populations for food security and fishery income (de la Torre-Castro and Ronnback 2004). Most artisanal harvesting is concentrated in the middle and upper intertidal due to a large bivalve population that attaches to belowground components of larger seagrass species, but plants from upper intertidal zones are also utilized. Data indicate that the upper intertidal infauna community does not appear to be vulnerable to disturbance at the scale of this study since fauna species richness and abundance values were not significantly different between treatments. There was, however, a loss of community biodiversity because increases in opportunistic polychaetes skewed the data and decreased evenness (Figure 3.9).

The return of plant structure following disturbance did not necessarily result in a corresponding return of the fauna community. For example, overall aboveground seagrass cover following the removal treatment in the lower intertidal reached pre- 
disturbance levels by the end of the experiment, but fauna abundance remained significantly lower. This is likely related to changes in the belowground components where younger shoots that have recently expanded into a new area will have smaller roots and rhizomes compared to more established plants (Di Carlo and Kenworthy 2008). The loss of the larger belowground components would result a loss of substrate needed for bivalve attachment. Belowground fauna substrate availability is also seagrass speciesspecific, and the initial replacement by the large T. ciliatum (mean belowground biomass $\left.=64 \mathrm{~g} \mathrm{~m}^{2}\right)$ by the smaller S. isoetifolium $\left(\right.$ mean $\left.=13 \mathrm{~g} \mathrm{~m}^{2}\right)$ may have further delayed fauna settlement and growth. In this situation, both external (disturbance driven loss of biomass) and internal (shifts in species dominance) forces may have resulted in reductions of infauna biodiversity and abundance. While this study highlights negative aspects of disturbance on associated fauna at the local scale, others suggest that smallscale biogenic disturbances (e.g. bioturbation) can play a positive role by increasing a community resistance to invasive animal species (Lohrer et al. 2008). Disturbances can also have cascading affects on other trophic processes including predation refuge for blue crabs (Hovel and Lipcius 2001) and urchins (Farina et al. 2009).

\section{Implications for Changing Disturbance Regimes and Restoration Efforts}

Physical disturbance has contributed to global losses of seagrass ecosystems, and disturbance regimes are expected to increase as a result of continuing human population growth and development along coasts (Orth et al. 2006). Recovery from small-scale discrete disturbances such as boat damage and destructive harvesting techniques were 
addressed directly in this study, and seagrass recolonization depends primarily on asexual reproduction via horizontal rhizome expansion into the surrounding areas (Rasheed 2004, Boese et al. 2009). Large-scale disturbances (e.g. floods and cyclones) are predicted to increase in intensity and/or frequency under some climate models (Emanuel 2005) and will rely more upon a source of new recruits then upon sexual reproduction. This is turn will favour species characteristic of greater sexual reproductive potential (e.g., $T$. hemprichii) or seed bank creation (e.g., H. uninervis) over species with limited seed dispersal abilities that depend largely on rhizome elongation (Olesen et al. 2004). Recovery from these large-scale disturbances is more difficult to forecast than the smallscale events because of a shortage of data on reproductive biology, but the use of studies at smaller spatial scales can still be useful for predicting disturbance resilience and recovery dynamics of individual seagrass species. For example, small-sized species with less anchorage structure are more prone to removal during a storm compared to larger species (Fourqurean and Rutten 2004). It is also difficult to identify at what point disturbance makes a community more vulnerable to future disturbances. For example, blowholes are a type of discrete physical disturbances caused by vessel groundings that results in deep depressions in the sediment, and their recovery is slowed due to subsequent disturbances such as storm events that enlarge the original excavation (Whitfield et al. 2002). More information is needed to predict how seagrasses will respond not only to multiple disturbance-specific stressors, but also interactions between disturbance and other stressors such as eutrophication (Dolbeth et al. 2007) and climate 
change factors, including sea level rise and increased temperature (Short and Neckles 1999).

Trends of current and future seagrass habitat loss have generated interest in ecological restoration (Paling et al. 2009). Experimental studies on seagrass removal and recovery, such as this one, can have direct applications to these efforts. One major restoration goal is to re-establish principal ecosystem functions such as habitat utilization, and this study demonstrated that the recovery of fauna diversity and abundance may not coincide with the return of seagrass cover. This study also complements existing restoration results, where recolonization may be hindered by consumer control and herbivory (Hauxwell et al. 2004) or bioturbation activity (Fonseca et al. 1996, Davis et al. 1998, Bastyan and Cambridge 2008). Because seagrass restoration is rarely conducted in mixed meadows, future efforts will require intentional considerations that incorporate species sensitivity to micro-topographical changes, especially in intertidal communities where exposure stress is an important driver of species success.

This investigation simulated naturally-occurring small-scale disturbance regimes in seagrass meadows. Several factors not explicitly addressed in this study may affect recovery dynamics such as initial disturbance severity (Patriquin 1975), size and geometry of the disturbance (Fonseca et al. 2004), and varying degrees of excavations (Hammerstrom et al. 2007) and burials (Duarte et al. 1997). The role of plant diversity in disturbance resilience or resistance (Elton 1958) within these mixed meadows is difficult 
to decipher because of the relatively low number of seagrass species, although genetic diversity may be locally important (Reusch and Hughes 2006). The comparative nature of our investigation highlighted differences between intertidal seagrass assemblages regarding disturbance resilience, recovery and ecosystem functions.

This study shows that recovery for mixed-species intertidal systems following small-scale disturbances is more complex than that represented in existing models of seagrass succession. Disturbance impacts on tropical intertidal seagrass structure and function is influenced by the interaction of different physical (e.g. sediment burial or removal) and biological (e.g. species specific tolerance to exposure and burial stress) factors. While the disturbance itself creates new opportunities for species colonization as seen in numerous other ecological communities, a key and novel mechanism for determining community composition is this community is elevation, which adds a third dimensional component to disturbance recovery. Predictions of intertidal seagrass recovery following disturbances should incorporate not only seagrass succession models that emphasize life history attributes, but also the role of disturbance type and related micro-topographical changes in water depth that may alter competitive dominance during recovery.

\section{References}

Anderson, V. J. and D. D. Briske. 1995. Herbivory-induced species replacement in grasslands: Is it driven by herbivory tolerance or avoidance? Ecological Applications 1014-1024. 
Bandeira, S., 2002. Diversity and distribution of seagrasses around Inhaca Island, southern Mozambique. South African Journal of Botany 68: 191-198.

Bastyan, G. R. and M. L. Cambridge. 2008. Transplantation as a method for restoring the seagrass Posidonia australis. Estuarine Coastal Shelf Science 79: 289-299.

Bell, S. S., B. D. Robbins, and S. L. Jensen. 1999. Gap dynamics in a seagrass landscape. Ecosystems 2: 493-504.

Bjork, M., J. Uku, A. Weil, and S. Beer. 1999. Photosynthetic tolerances to desiccation of tropical intertidal seagrasses. Marine Ecology Progress Series 191: 121-126.

Boese, B. L., J. E. Kaldy, P. J. Clinton, P. M. Eldridge, and C. L. Folger. 2009. Recolonization of intertidal Zostera marina L. (eelgrass) following experimental shoot removal. Journal of Experimental Marine Biology and Ecology 374: 69-77.

Cabaco, S., R. Santos, and C. M. Duarte. 2008. The impact of sediment burial and erosion on seagrasses: A review. Estuarine Coastal Shelf Science 79: 354-366.

Ceccherelli, G., D. Campo, and M. Milazzo. 2007. Short-term response of the slow growing seagrass Posidonia oceanica to simulated anchor impact. Marine Environmental Research 63: 341-349.

Creed, J. C. and G. M. Amado. 1999. Disturbance and recovery of the macroflora of a seagrass (Halodule wrightii Ascherson) meadow in the Abrolhos Marine National Park, Brazil: an experimental evaluation of anchor damage. Journal of Experimental Marine Biology and Ecology 235: 285-306.

Davis, R. C., F. T. Short, and D. M. Burdick. 1998. Quantifying the effects of green crab damage to eelgrass transplants. Restoration Ecology 6: 297-302.

den Hartog, C., 1971. The dynamic aspect in the ecology of seagrass communities. Thalassia Testudinum Jugoslavica 101-112.

Di Carlo, G. and W. J. Kenworthy. 2008. Evaluation of aboveground and belowground biomass recovery in physically disturbed seagrass beds. Oecologia 158: 285-298.

Dolbeth, M., P. G. Cardoso, S. M. Ferreira, T. Verdelhos, D. Raffaelli, and M. A. Pardal. 2007. Anthropogenic and natural disturbance effects on a macrobenthic estuarine community over a 10-year period. Marine Pollution Bulletin 54: 576-585.

Duarte, C. M., 1999. Seagrass ecology at the turn of the millennium: challenges for the new century. Aquatic Botany 65: -20.

Duarte, C. M., 2002. The future of seagrass meadows. Environmental Conservation 29: 192-206.

Duarte, C. M., J. Terrados, N. S. R. Agawin, and M. D. Fortes. 2000. An experimental test of the occurrence of competitive interactions among SE Asian seagrasses. Marine Ecology Progress Series 197: 231-240.

Duarte, C. M., J. Terrados, N. S. R. Agawin, M. D. Fortes, S. Bach, and W. J. Kenworthy. 1997. Response of a mixed Philippine seagrass meadow to experimental burial. Marine Ecology Progress Series 147: 285-294.

Eckrich, C. E. and J. G. Holmquist. 2000. Trampling in a seagrass assemblage: direct effects, response of associated fauna, and the role of substrate characteristics. Marine Ecology Progress Series 201: 199-209.

Ellison, A. M., 1987. Effects of competition, disturbance, and herbivory on Salicornia europaea. Ecology 68: 576-586. 
Elton, C. S., 1958. Ecology of Invasions by Animals and Plants. Chapman and Hall, London.

Emanuel, K., 2005. Increasing destructiveness of tropical cyclones over the past 30 years. Nature 436: 686-688.

Erftemeijer, P. L. A. and R. R. R. Lewis. 2006. Environmental impacts of dredging on seagrasses: A review. Marine Pollution Bulletin 52: 1553-1572.

Farina, S., F. Tomas, P. Prado, J. Romero, and T. Alcoverro. 2009. Seagrass meadow structure alters interactions between the sea urchin Paracentrotus lividus and its predators. Marine Ecology Progress Series 131-137.

Fonseca, M. S., P. E. Whitfield, W. J. Kenworthy, D. R. Colby, and B. E. Julius. 2004. Use of two spatially explicit models to determine the effect of injury geometry on natural resource recovery. Aquatic Conservation 14: 281-298.

Fonseca, M. S., W. J. Kenworthy, and F. X. Courtney. 1996. Development of planted seagrass beds in Tampa Bay, Florida, USA .1. Plant components. Marine Ecology Progress Series 132: 127-139.

Fourqurean, J. W. and L. M. Rutten. 2004. The impact of Hurricane Georges on softbottom, back reef communities: Site- and species-specific effects in south Florida seagrass beds. Bulletin of Marine Science 75: 239-257.

Gullstrom, M., M. de la Torre Castro, S. O. Bandeira, M. Bjork, M. Dahlberg, N. Kautsky, P. Ronnback, and M. C. Ohman. 2002. Seagrass ecosystems in the Western Indian Ocean. AMBIO 31: 588-596.

Hammerstrom, K. K., W. J. Kenworthy, P. E. Whitfield, and M. F. Merell. 2007. Response and recovery dynamics of seagrasses Thalassia testudinum and Syringodium filiforme and macroalgae in experimental motor vessel disturbances. Marine Ecology Progress Series 345: 83-92.

Hauxwell, J., C. W. Osenberg, and T. K. Frazer. 2004. Conflicting management goals: Manatees and invasive competitors inhibit restoration of a native macrophyte. Ecological Applications 14: 571-586.

Heck, K. L. and J. F. Valentine. 2006. Plant-herbivore interactions in seagrass meadows. Journal of Experimental Marine Biology and Ecology 330: 420-436.

Holmquist, J. G., 1997. Disturbance and gap formation in a marine benthic mosaic: influence of shifting macroalgal patches on seagrass structure and mobile invertebrates. Marine Ecology Progress Series 158: 121-130.

Hovel, K. A. and R. N. Lipcius. 2001. Habitat fragmentation in a seagrass landscape: Patch size and complexity control blue crab survival. Ecology 82: 1814-1829.

[NO STYLE for: Nordlund 2006].

Huston, M. A., 1994. Biolgoical Diversity: The coexistence of species on changing landscapes. Cambridge University Press, Cambridge.

Kenworthy, W. J. and M. S. Fonseca. 1992. The use of fertilizer to enhance growth of transplanted seagrasses Zostera marina and Halodule wrightii aschers. Journal of Experimental Marine Biology and Ecology 163: 141-161.

Kenworthy, W. J., M. S. Fonseca, P. E. Whitfield, and K. K. Hammerstrom . 2002. Analysis of seagrass recovery in experimental excavations and propeller-scar 
disturbances in the Florida Keys National Marine Sanctuary. Journal of Coastal Research 75-85.

Kirsch, K. D., J. F. Valentine, and K. L. Heck. 2002. Parrotfish grazing on turtlegrass

Thalassia testudinum: evidence for the importance of seagrass consumption in food web dynamics of the Florida Keys National Marine Sanctuary. Marine Ecology Progress Series 227: 71-85.

Kirsch, K. D., K. A. Barry, M. S. Fonseca, P. E. Whitfield, S. R. Meehan, W. J. Kenworthy, and B. E. Julius. 2005. The mini-312 program - An expedited damage assessment and restoration process for seagrasses in the Florida Keys National Marine Sanctuary. Journal of Coastal Research 109-119.

de la Torre-Castro, M. and P. Ronnback. 2004. Links between humans and seagrasses an example from tropical East Africa. Ocean and Coastal Management 47: 361387.

Lohrer, A. M., L. D. Chiaroni, J. E. Hewitt, and S. F. Thrush. 2008. Biogenic disturbance determines invasion success in a subtidal soft-sediment system. Ecology 89: 1299-1307.

Lubchenco, J., 1980. Algal zonation in the New England rocky intertidal community: An experimental analysis. Ecology 61: 333-344.

Martin, S. R., C. P. Onuf, and K. H. Dunton. 2008. Assessment of propeller and off-road vehicle scarring in seagrass beds and wind-tidal flats of the southwestern Gulf of Mexico. Botanic Marina 51: 79-91.

McRoy, C. P. and C. McMillan. 1977. Production and physiology of seagrasses, pp. 5388 in Seagrass ecosystems: A scientific perspective. Marcel Dekker, New York.

1995. A Natural History of Inhaca Island, Mozambique, edited by M. Kalk. Witwatersrand University Press, Johannesburg.

Nellemann, C., E. Corcoran, C. Duarte, M. Valdes, C. De Young, L. Fonseca, and G. Grimsditch. 2009. Blue carbon - The role of healthy oceans in binding carbon. A rapid response assessment. United Nations Environment Programme.

Oldeman, R. A. A., 1978. Architecture and energy exchange of dicotyledonous trees in the forest. Tropical Trees as Living Systems. Cambridge University Press, Cambridge.

Olesen, B., N. Marba, C. M. Duarte, R. S. Savela, and M. D. Fortes. 2004. Recolonization dynamics in a mixed seagrass meadow: The role of clonal versus sexual processes. Estuaries 27: 770-780.

Orth, R. J., T. J. B. Carruthers, W. C. Dennison, C. M. Duarte, J. W. Fourqurean, K. L. Heck, A. R. Hughes, G. A. Kendrick, W. J. Kenworthy, S. Olyarnik, F. T. Short, M. Waycott, and S. L. Williams. 2006. A global crisis for seagrass ecosystems. Bioscience 56: 987-996.

Paling, E. I., M. Fonseca, M. M. van Katwijk, and M. van Keulen. 2009. Seagrass Restoration, in Coastal wetlands: an integrated ecosystem approach. Elsevier, Amsterdam.

Patriquin, D. G., 1975. "Migration" of blowouts in seagrass beds at Barbados and Carriacou, West Indies, and its ecological and geological implications. Aquatic Botany 163-189. 
Paula, J., P. F. E. Costa, A. Martins, and D. Gove. 2001. Patterns of abundance of seagrasses and associated infaunal communities at Inhaca Island, Mozambique. Estuarine Coastal Shelf Science 53: 307-318.

Peralta, G., F. G. Brun, I. Hernandez, J. J. Vergara, and J. L. Perez-Llorens. 2005. Morphometric variations as acclimation mechanisms in Zostera noltii beds. Estuarine, Coastal and Shelf Science 64: 347-356.

Pickett, S. T. A. and B. White. 1985. The ecology of natural disturbances and patch dynamics. Academic Press, Orlando, FL.

Platt, W. J., 1975. The colonization and formation of equilibrium plant species associations on badger disturbances in a tall-grass prairie. Ecological Monographs 285-305.

Rasheed, M. A., 2004. Recovery and succession in a multi-species tropical seagrass meadow following experimental disturbance: the role of sexual and asexual reproduction. Journal of Experimental Marine Biology and Ecology 310: 13-45.

Reusch, T. B. H. and A. R. Hughes. 2006. The emerging role of genetic diversity for ecosystem functioning: Estuarine macrophytes as models. Estuaries and Coasts 29: 159-164.

Rollon, R. N., E. D. D. Van Steveninck, W. Van Vierssen, and M. D. Fortes. 1998. Contrasting recolonization strategies in multi-species seagrass meadows. Marine Pollution Bulletin 37: 450-459.

Shafer, D. J., T. D. Sherman, and S. Wyllie-Echeverria. 2007. Do desiccation tolerances control the vertical distribution of intertidal seagrasses? Aquatic Botany 87: 161166.

Sherman, R. E., T. J. Fahey, and J. J. Battles. 2000. Small-scale disturbance and regeneration dynamics in a neotropical mangrove forest. Journal of Ecology 88: 165-178.

Short, F. T. and H. A. Neckles. 1999. The effects of global climate change on seagrasses. Aquatic Botany 63: 169-196.

Short, F. T. and S. Wyllie-Echeverria. 1996. Natural and human-induced disturbance of seagrasses. Environmental Conservation 23: 17-27.

Short, F., T. Carruthers, W. Dennison, and M. Waycott. 2007. Global seagrass distribution and diversity: A bioregional model. Journal of Experimental Marine Biology and Ecology 350: 3-20.

Townsend, E. C. and M. S. Fonseca. 1998. Bioturbation as a potential mechanism influencing spatial heterogeneity of North Carolina seagrass beds. Marine Ecology Progress Series 169: 123-132.

Valentine, J. F. and K. L. Heck. 1999. Seagrass herbivory: evidence for the continued grazing of marine grasses. Marine Ecology Progress Series 176: 291-302.

Valentine, J. F., K. L. Heck, P. Harper, and M. Beck. 1994. Effects of bioturbation in controlling Turtlegrass (Thalassia testudinum Banks Ex Konig), abundance Evidence from field enclosures and observations in the Northern Gulf of Mexico. Journal of Experimental Marine Biology and Ecology 178: 181-192. 
Vermaat, J. E., N. S. R. Agawin, C. M. Duarte, M. D. Fortes, N. Marba, and J. S. Uri. 1995. Meadow maintenance, growth and productivity of a mixed Philippine seagrass bed. Marine Ecology Progress Series 124: 215-225.

Walker, D. I., R. J. Lukatelich, G. Bastyan, and A. J. McComb. 1989. Effect of boat moorings on seagrass beds near Perth, Western Australia. Aquatic Botany 36: 6977.

Watt, A. S., 1947. Pattern and process in the plant community. Journal of Ecology 35: 122.

Waycott, M., C. M. Duarte, T. J. Carruthers, R. J. Orth, W. C. Dennison, S. Olyarnik, A. Calladine, J. W. Fourqurean, K. L. Heck, A. R. Hughes, G. A. Kendrick, W. J. Kenworthy, F. T. Short, and S. L. Williams. 2009. Accelerating loss of seagrasses across the globe threatens coastal ecosystems. Proceedings of the National Academy of the United States of America .

Whitfield, P. E., J. W. Kenworthy, K. K. Hammerstrom, and M. S. Fonseca. 2002. The role of a hurricane in the expansion of disturbances initiated by motor vessels on seagrass banks. Journal of Coastal Research 86-99 .

Williams, S. L., 1990. Experimental studies of Caribbean seagrass bed development. Ecological Monographs 60: 449-469.

Zieman, J. C., 1976. The ecological effects of physical damage from motor boats on turtle grass beds in Southern Florida. Aquatic Botany 127-139.

Zieman, J. C., 1982. The ecology of the seagrasses of south Florida: a community profile. US Fish and Wildlife Service, Office of Biological Services, Washington. 


\section{Figures}

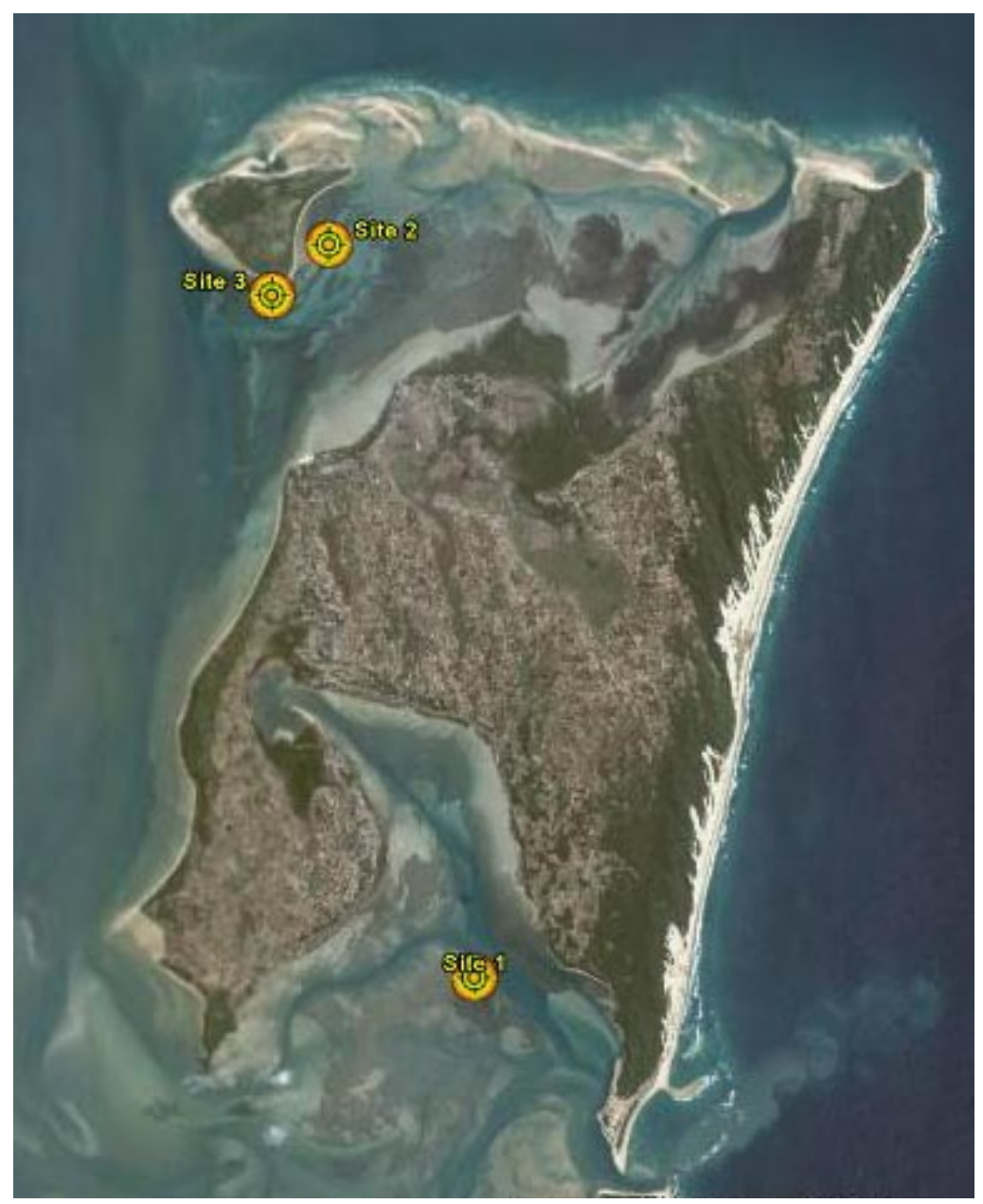

Figure 3.1. Map of Inhaca island and disturbance experiment sites. Site 1 = upper intertidal; Site 2 = middle intertidal; Site $3=$ lower intertidal. 


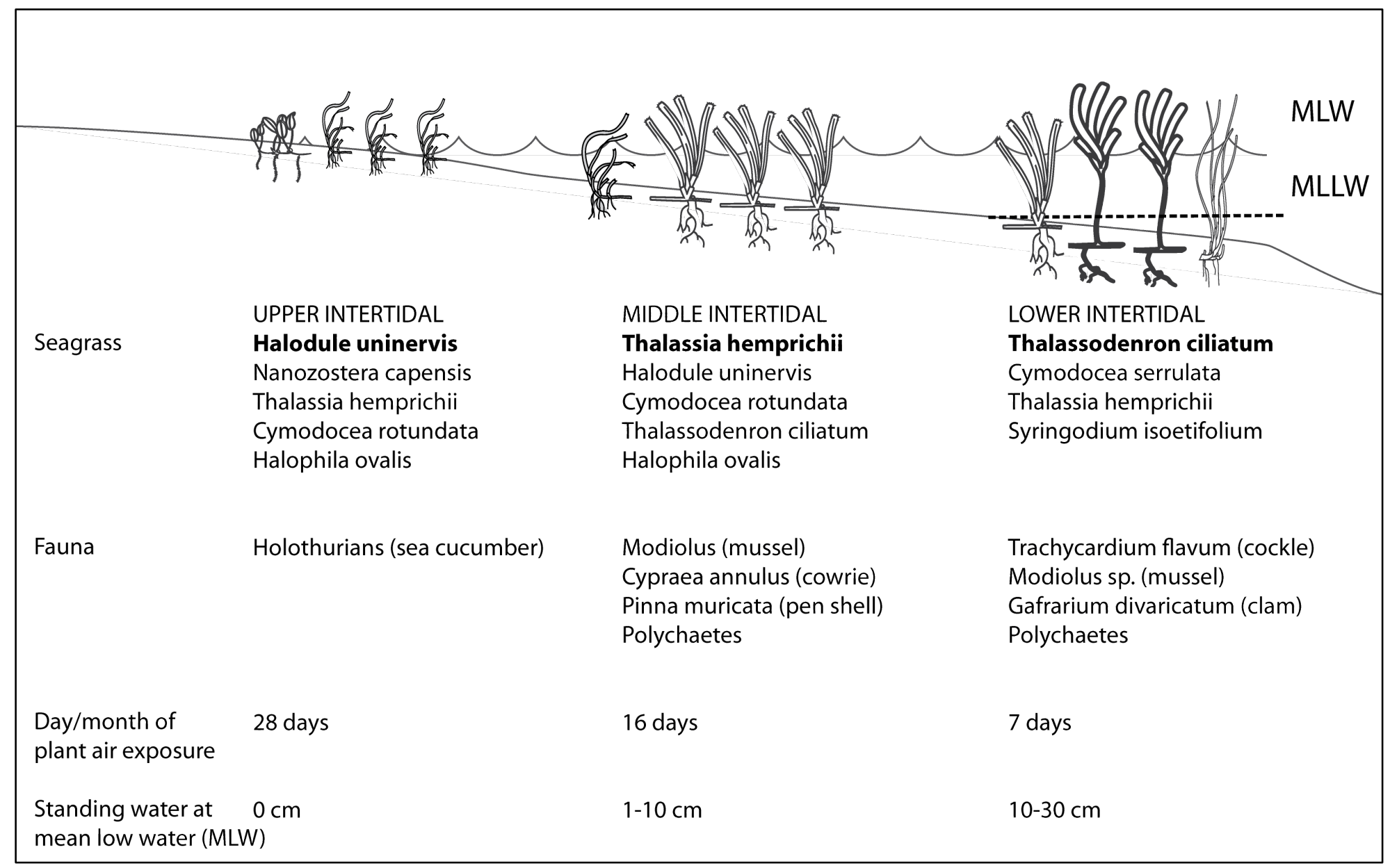

Figure 3.2. Profile of common flora and fauna composition at experimental sites.

Species are listed in order of abundance with the dominant species and community type in bold. 


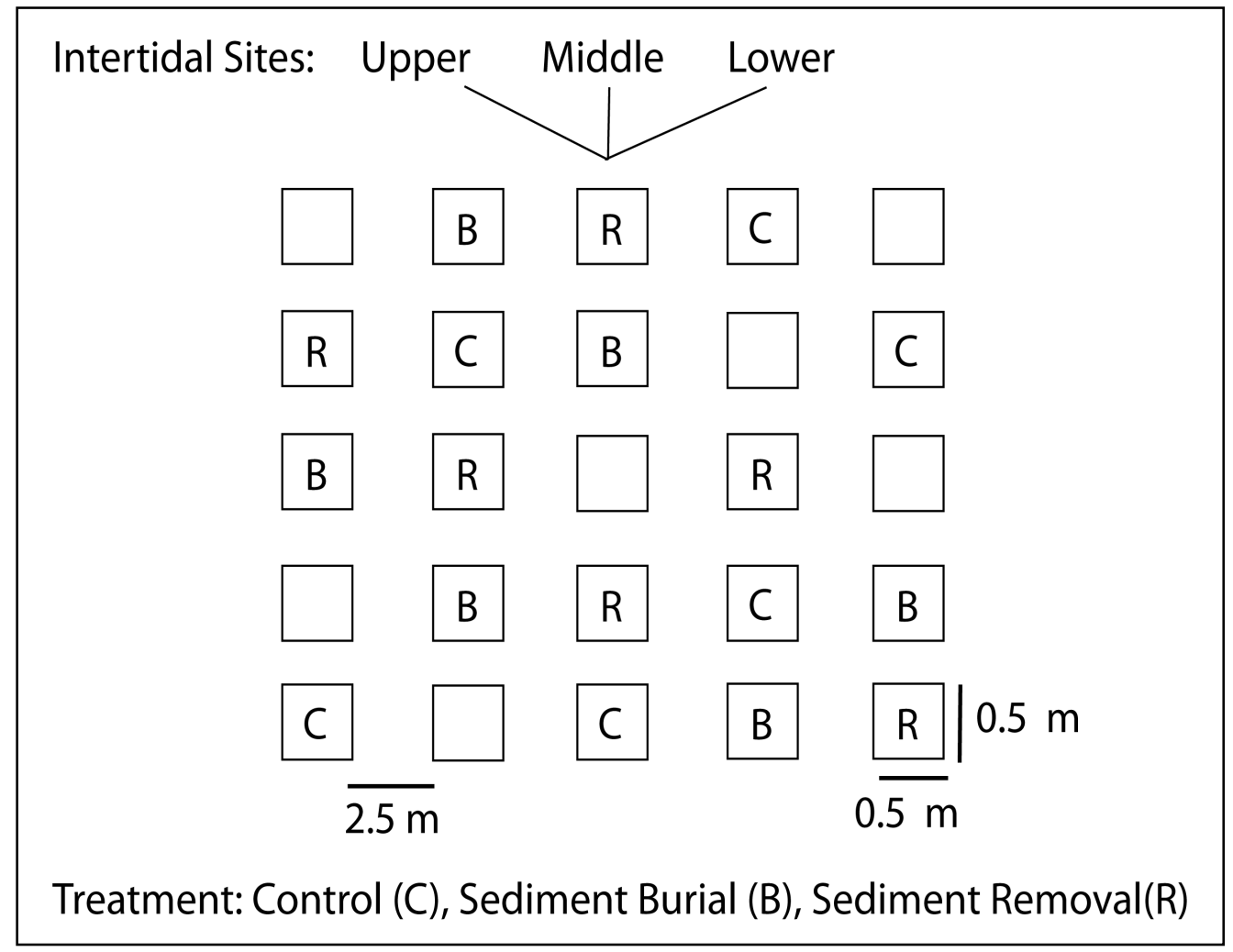

Figure 3.3. Experimental design of the disturbance experiment.

Three sites along the intertidal gradient (High, Middle, Low), three treatments: Control (C), Burial (B), Removal (R); Six $0.25 \mathrm{~m}^{2}$ plot replicates of each treatment at each site, Total $\mathrm{N}=54$. 


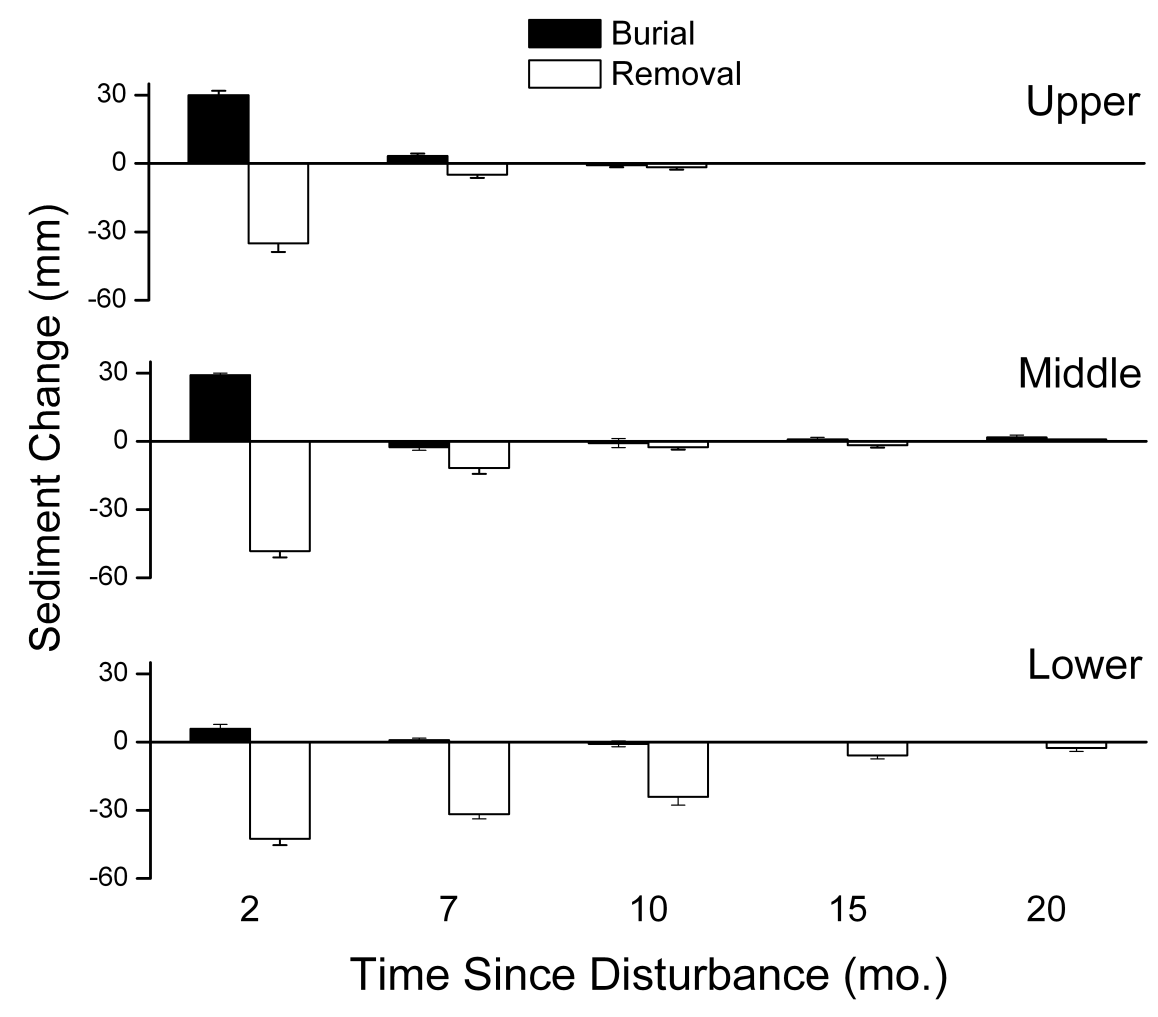

Figure 3.4. Changes in mean sediment depth change relative to pre-disturbance levels. Error bars are $+1 \mathrm{SE}, \mathrm{n}=6$. 


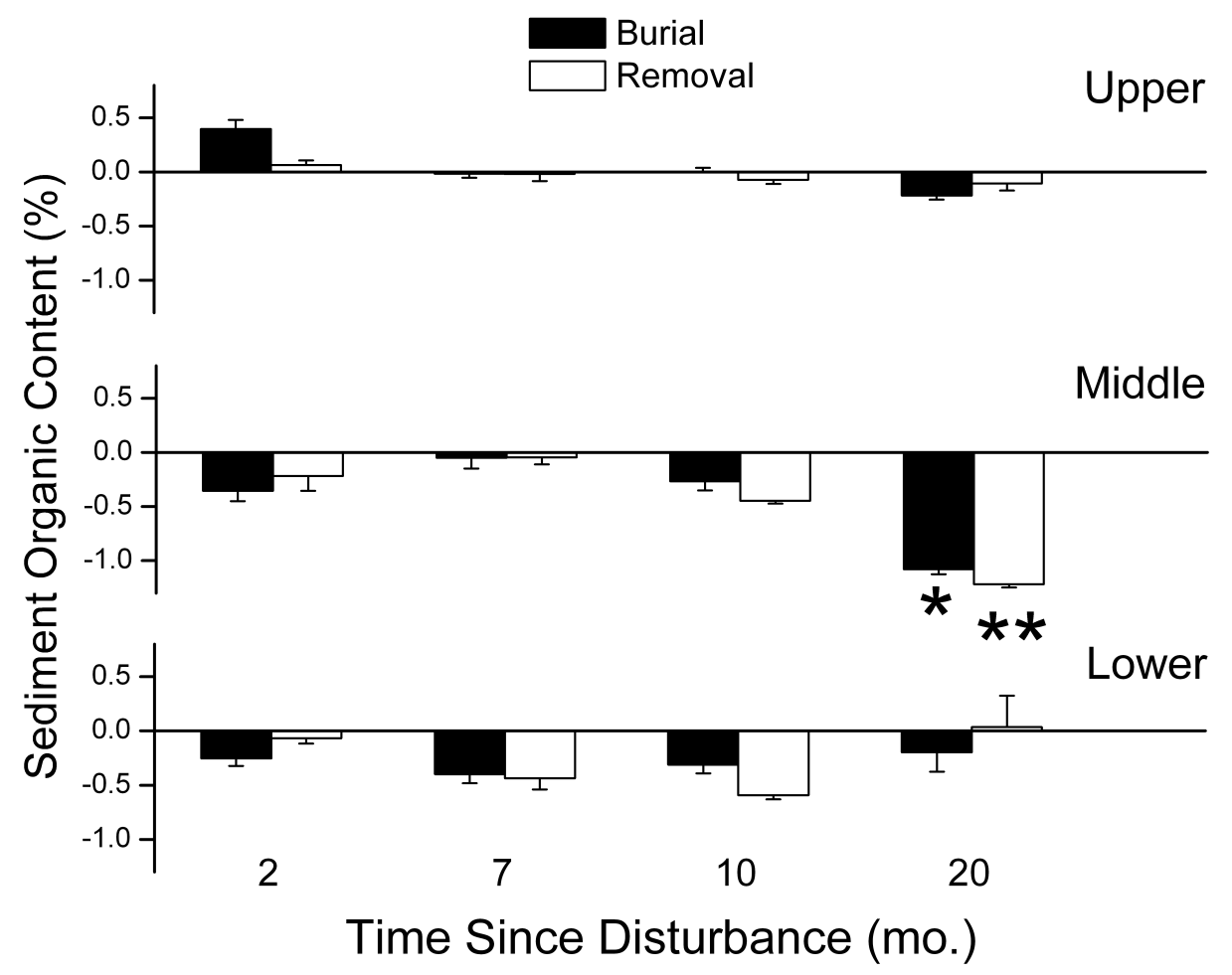

Figure 3.5. Changes in mean sediment organic content relative to pre-disturbance levels. Sediment organic content is \% dry weight. Asterisks represent significant difference from controls at the end of the experiment; ** $=\mathrm{p}<0.05, *=\mathrm{p}<0.10$ 


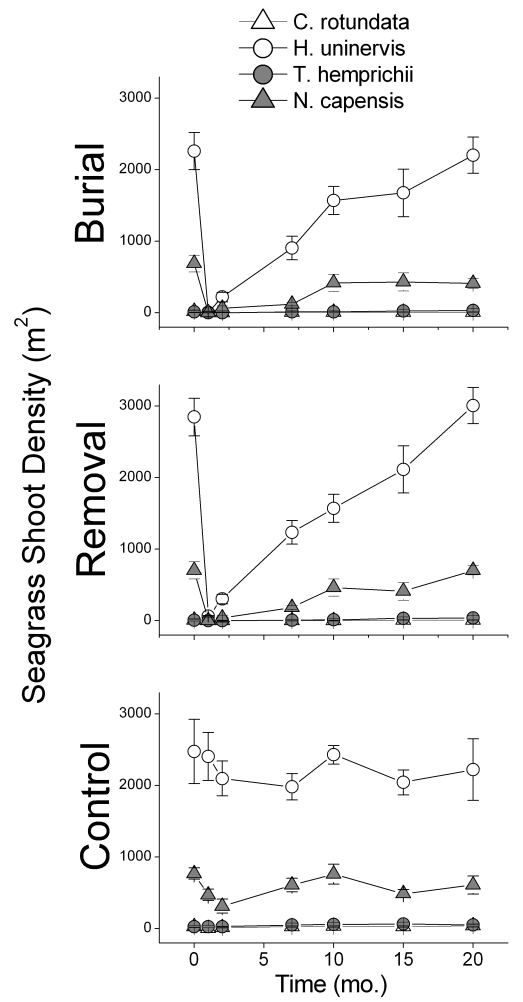

Upper
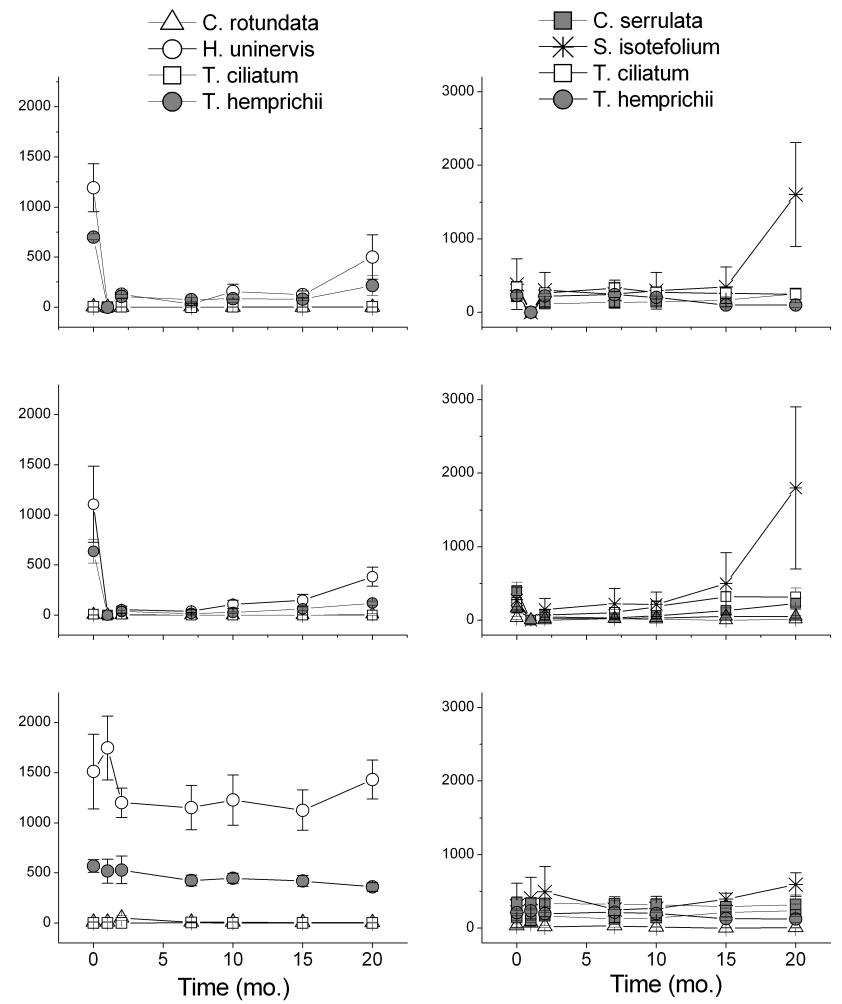

Middle

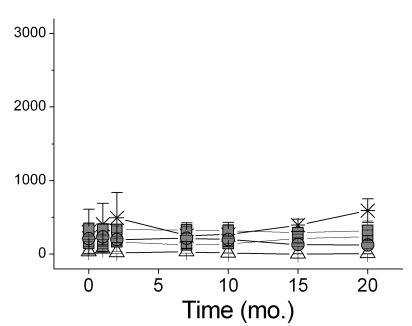

Lower

Figure 3.6. Seagrass shoot density over time by species and disturbance treatment. Error bars are $+1 \mathrm{SE}, \mathrm{n}=6$. Halophila ovalis was not included due to high seasonality. 

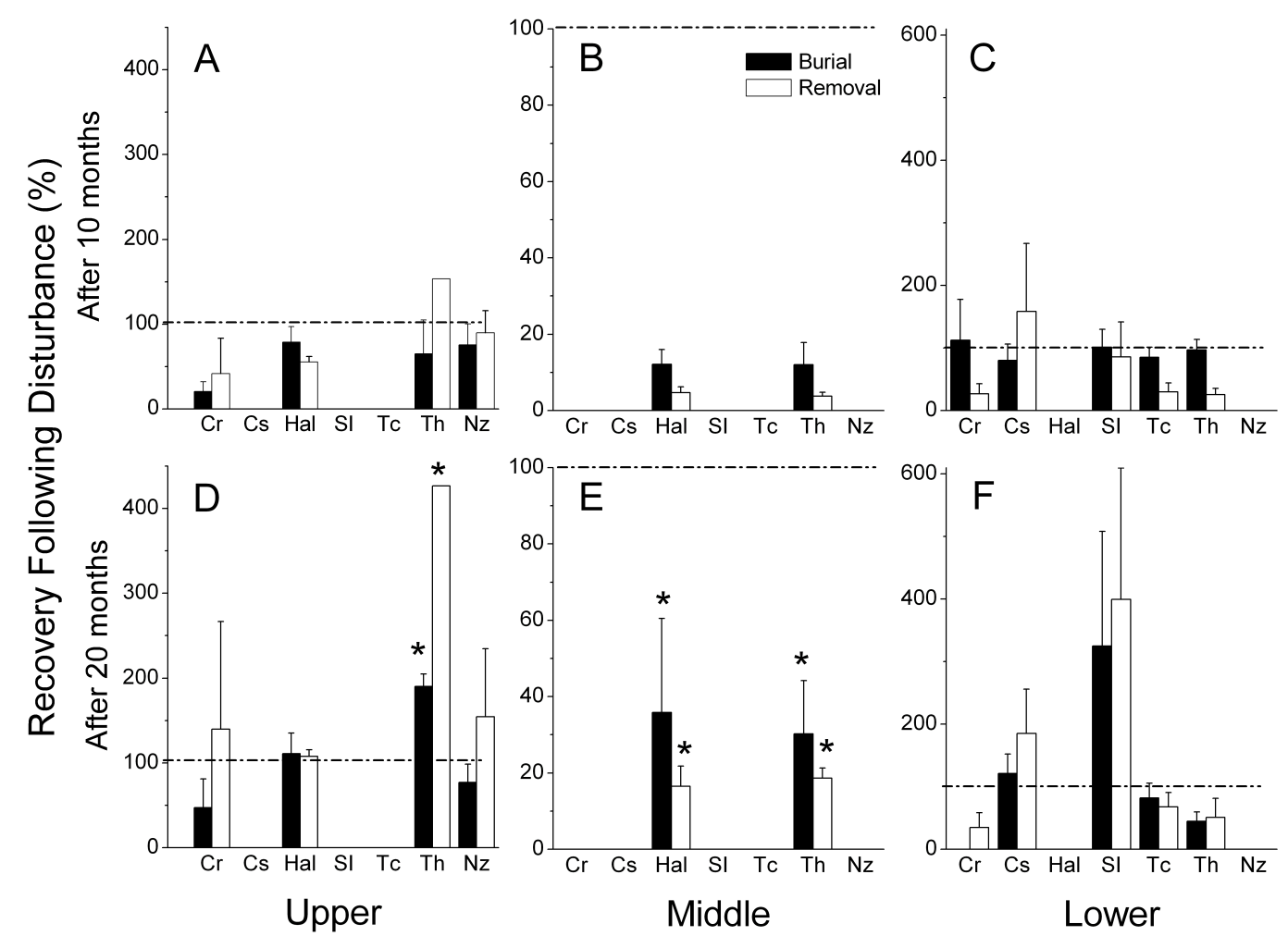

Figure 3.7. Recovery of individual seagrass species compared to pre-disturbance levels. Data are means $+\mathrm{SE}, \mathrm{n}$ varies because all species were not found in all plots. A dashed line at the 1 value indicates $100 \%$ recovery. Dominant species based on percent cover and contribution to biomass are underlined. 

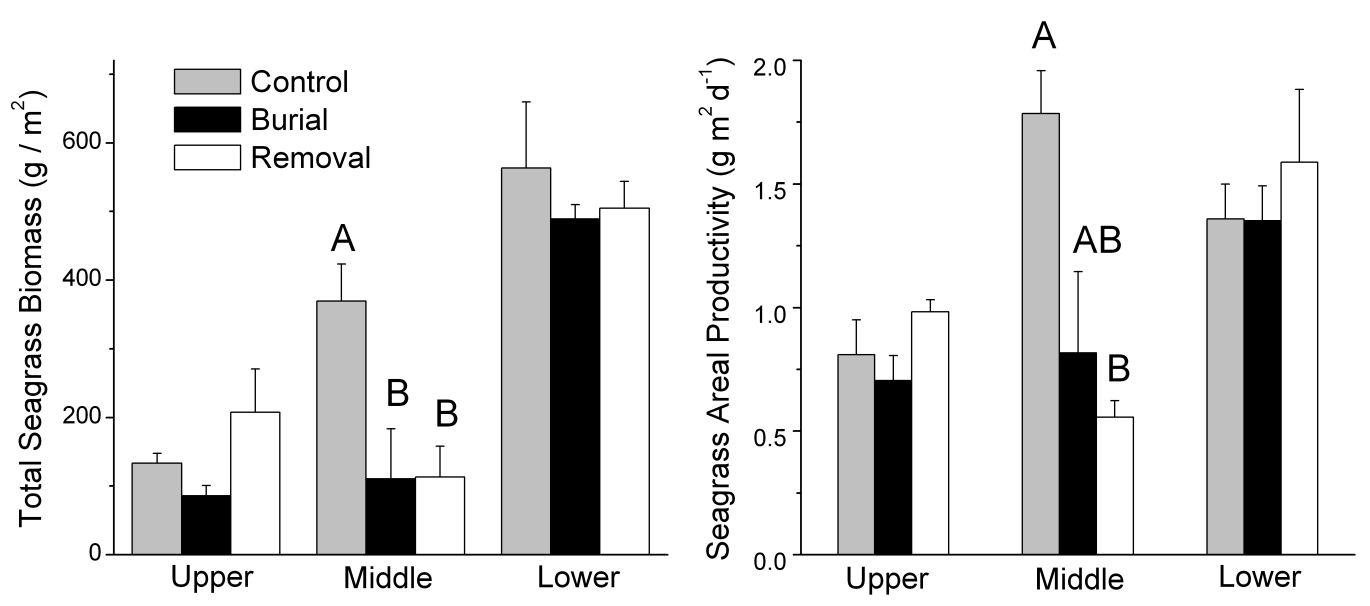

Figure 3.8. Total seagrass biomass and areal productivity 20 months following the disturbance.

Seagrass biomass includes above and belowground components. Productivity values represent the sum of all seagrass species present. Letters indicates statistically different means within each site, $p=<0.05$. Mean values $+1 \mathrm{SE}$. $\mathrm{N}=6$. 

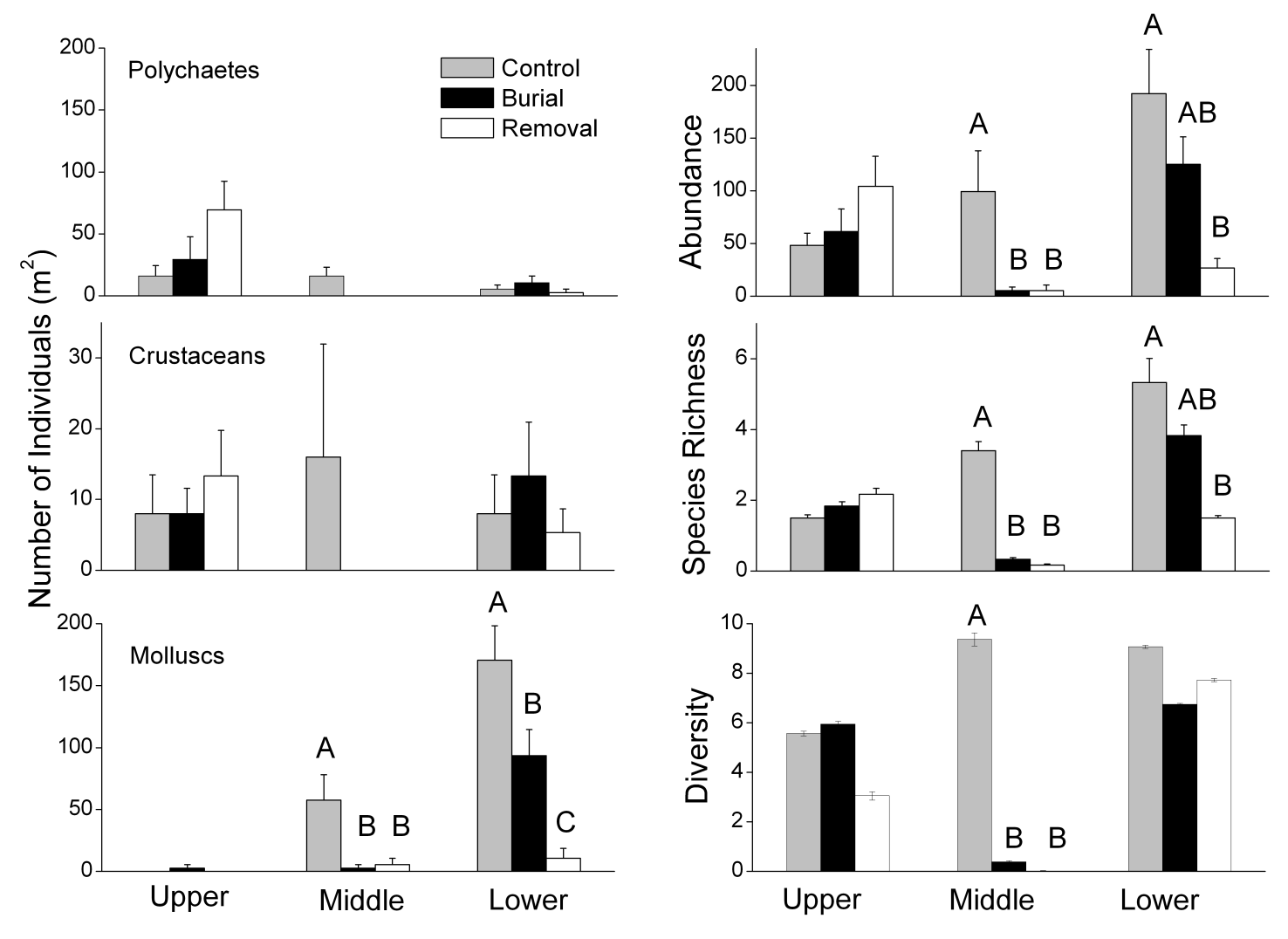

Figure 3.9. Response of fauna community 20 months following the disturbance.

Fauna is separated into the three dominant taxonomic groups (polychaetes, crustaceans, mollusks), Abundance is total number of individual organisms, Species Richness is total number of species, and Diversity is Shannon's Diversity Index. Letters indicates statistically different means within each site, $p=<0.05$. Mean values $+1 \mathrm{SE} . \mathrm{N}=6$. 


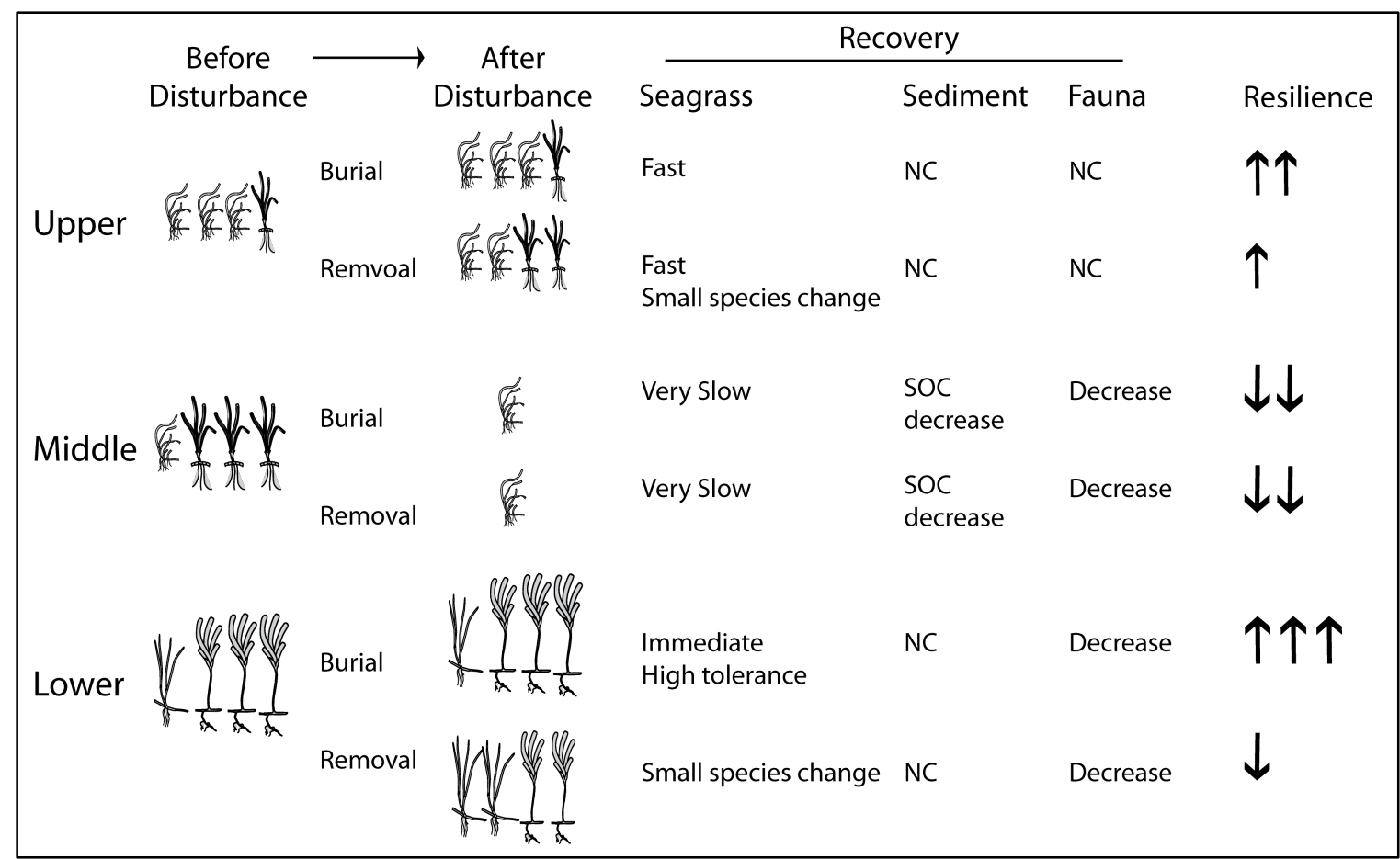

Figure 3.10. Summary of results by intertidal site (upper, middle, lower) and treatment (burial, removal).

$\mathrm{NC}=$ no change. $\mathrm{SOC}=$ sediment organic content. Seagrass refers to shoot density, sediment refers to organic content, and fauna refers to species richness and diversity. Direction and number of arrows represent the relative resilience to disturbance. 


\section{Tables}

\begin{tabular}{|c|c|c|c|c|}
\hline & Upper & Middle & Lower & $\begin{array}{c}t \text {-test } \\
p \text { value }\end{array}$ \\
\hline \multicolumn{5}{|l|}{ Water } \\
\hline Leaf Exposure (days/mo.) & 28 & 16 & 7 & \\
\hline Temperature Range $\left(\mathrm{C}^{\mathrm{o}}\right)$ & $10.8-46.5$ & $12.9-42.3$ & $15.4-42.4$ & \\
\hline Temperature Mean $\left(\mathrm{C}^{0}\right)$ & 26.3 & 24.7 & 26 & \\
\hline MLW depth (mm) & 25 & 59 & 75 & \\
\hline \multicolumn{5}{|l|}{ Sediment } \\
\hline Coarse sediment (\%) & 0.07 & 0.33 & 0.39 & \\
\hline Medium sediment $(\%)$ & 0.91 & 0.65 & 0.58 & \\
\hline Fine sediment $(\%)$ & 0.03 & 0.02 & 0.02 & \\
\hline Sedimentation $(\mathrm{cm} / \mathrm{yr})$ & 0.09 & 0.94 & 0.32 & 0.010 \\
\hline Organic Content ( $\%$ afdw) & 0.869 & 1.037 & 0.938 & 0.244 \\
\hline Total Nitrogen (\% dw) & 0.131 & 0.841 & 0.809 & 0.003 \\
\hline Total Phosphorus (\% dw) & 0.0031 & 0.0285 & 0.0592 & $<0.001$ \\
\hline \multicolumn{5}{|l|}{ Seagrass } \\
\hline Cover $(\%)$ & $50 \%$ & $80 \%$ & $100 \%$ & \\
\hline
\end{tabular}

Table 3.1. Summary of water, sediment and seagrass characterists for each intertidal site. Values are means. Bold t-test values indicate a significant difference between sites where $\mathrm{p}<0.05$. Sediment grain size distribution is based on sieve size, where Coarse, Medium and Fine are 5, 2.5, and 0.63 sieve width $(\mathrm{mm})$. 


\begin{tabular}{|c|c|c|c|c|c|c|c|c|c|c|}
\hline & & \multicolumn{4}{|c|}{ Between-Subjects } & \multicolumn{5}{|c|}{ Within-Subjects } \\
\hline \multicolumn{2}{|c|}{ Species } & Disturbance (D) & Site (S) & DxS & Error & Time $(\mathrm{T})$ & $\mathrm{T} \times \mathrm{S}$ & $T \times D$ & $T \times D \times S$ & Error \\
\hline \multirow[t]{3}{*}{$\mathrm{Hal}$} & df & 2 & 1 & 2 & 29 & 4 & 4 & 8 & 8 & 116 \\
\hline & $F$ & 19.969 & 13.937 & 1.625 & & 25.304 & 10.398 & 5.644 & 4.044 & \\
\hline & $P$ & $<.001$ & 0.001 & 0.214 & & $<0.001$ & $<0.001$ & $<0.001$ & $<0.001$ & \\
\hline \multirow[t]{3}{*}{$\mathrm{Nz}$} & $\mathrm{df}$ & 2 & - & - & 15 & 1.711 & - & 3.423 & - & 25.67 \\
\hline & $F$ & 0.547 & - & - & & 6.903 & - & 1.956 & - & \\
\hline & $P$ & 0.590 & - & - & & 0.006 & - & 0.139 & - & \\
\hline \multirow[t]{3}{*}{$\mathrm{Cr}$} & df & 2 & 1 & 2 & 15 & 2.295 & 2.295 & 4.59 & 4.59 & 34.428 \\
\hline & $F$ & 1.279 & 0.006 & 0.487 & & 0.154 & 6.721 & 1.465 & 1.521 & \\
\hline & $P$ & 0.307 & 0.937 & 0.624 & & 0.884 & 0.002 & 0.230 & 0.212 & \\
\hline \multirow[t]{3}{*}{ Th } & df & 2 & 2 & 4 & 33 & 4 & 8 & 8 & 16 & 132 \\
\hline & $F$ & 6.749 & 28.626 & 6.587 & & 30.738 & 30.243 & 13.281 & 5.786 & \\
\hline & $P$ & 0.003 & $<0.001$ & 0.001 & & $<0.001$ & $<0.001$ & $<0.001$ & $<0.001$ & \\
\hline \multirow[t]{3}{*}{ Cs } & df & 2 & - & - & 15 & 2.867 & - & 5.733 & - & 42.594 \\
\hline & $F$ & 0.411 & - & - & & $5 . .558$ & - & 1.699 & - & \\
\hline & $P$ & 0.670 & - & - & & 0.003 & - & 0.147 & - & \\
\hline \multirow[t]{3}{*}{$\mathrm{Si}$} & df & 2 & - & - & 15 & 3.91 & - & 7.82 & - & 7.82 \\
\hline & $F$ & 0.547 & - & - & & 1.409 & - & 0.453 & - & \\
\hline & $P$ & 0.590 & - & - & & 0.314 & - & 0.855 & - & \\
\hline \multirow[t]{3}{*}{ Tc } & df & 2 & - & - & 15 & 4 & - & 8 & - & 60 \\
\hline & $F$ & 7.299 & - & - & & 0.919 & - & 3.863 & - & \\
\hline & $P$ & 0.006 & - & - & & 0.459 & - & 0.001 & - & \\
\hline
\end{tabular}

Table 3.2. ANOVA table for repeated measures analysis of seagrass species shoot density over time. Species found at only one site were excluded from site comparisons and are left blank. 


\begin{tabular}{|c|c|c|c|c|c|c|c|c|c|c|c|c|c|}
\hline & & \multicolumn{4}{|c|}{ Upper } & \multicolumn{4}{|c|}{ Middle } & \multicolumn{4}{|c|}{ Lower } \\
\hline & & $p$ value & C & $\mathrm{B}$ & $\mathrm{R}$ & $p$ value & $\mathrm{C}$ & $\mathrm{B}$ & $\mathrm{R}$ & $p$ value & C & $\mathrm{B}$ & $\mathrm{R}$ \\
\hline Seagrass & $\mathrm{H}$. uninervis & 0.965 & & & & $<0.001$ & $\bar{a}$ & $\bar{b}$ & $\bar{b}$ & & & & \\
\hline \multirow{6}{*}{ Species } & N. capensis & 0.447 & & & & & & & & & & & \\
\hline & C. rotundata & 0.414 & & & & & & & & 0.429 & & & \\
\hline & T. hemprichii & 0.013 & a & $\mathrm{a}$ & $b$ & $<0.032$ & a & $a b$ & $b$ & 0.957 & & & \\
\hline & C. serrulata & 0.645 & & & & & & & & 0.645 & & & \\
\hline & S. isoetifolium & & & & & & & & & 0.801 & & & \\
\hline & T. ciliatium & & & & & & & & & 0.865 & & & \\
\hline Seagrass & Biomass & 0.078 & & & & 0.012 & a & b & $b$ & 0.674 & & & \\
\hline Community & Leaf Productivity & 0.197 & & & & 0.003 & a & $b$ & $b$ & 0.661 & & & \\
\hline \multirow[t]{5}{*}{ Fauna } & Species Richness & 0.632 & & & & 0.014 & a & $b$ & $b$ & 0.033 & a & $a b$ & $\mathrm{~b}$ \\
\hline & Total Abundance & 0.194 & & & & 0.008 & a & $b$ & $b$ & 0.004 & a & $a b$ & $\mathrm{~b}$ \\
\hline & Polychaete & 0.119 & & & & 0.012 & a & $b$ & $b$ & 0.371 & & & \\
\hline & Crustacean & 0.718 & & & & 0.321 & & & & 0.616 & & & \\
\hline & Molluscs & 0.391 & & & & 0.006 & $a b$ & $b$ & $\mathrm{~b}$ & $<0.001$ & $a$ & $\mathrm{~b}$ & C \\
\hline
\end{tabular}

Table 3.3. Comparison of seagrass and fauna parameters for control (C), burial (B) and removal $(\mathrm{R})$ disturbance treatments at each site after 20 months.

Comparisons made using univariate ANOVA. Significant differences between means $(<0.05)$ are in bold. Letters indicated significant differences between treatments based on post-hoc comparisons. 


\section{Appendix}

\begin{tabular}{|c|c|c|c|c|c|c|c|c|c|}
\hline Location & Authors & Tidal Zone & Seagrass Assemblage & $\begin{array}{c}\text { Scale of } \\
\text { disturbance }\end{array}$ & $\begin{array}{c}\text { Type of } \\
\text { Disturbance }\end{array}$ & $\begin{array}{l}\text { Duration of } \\
\text { Experiment }\end{array}$ & Seagrass & Sediment & Fauna \\
\hline \multicolumn{10}{|l|}{ Caribbean } \\
\hline Brazil & Creed and Filho 1999 & Subtidal & $\mathrm{Hw}$ & $0.25 \mathrm{~m} 2$ & Clearing & $13 \mathrm{mo}$. & yes & no & no \\
\hline $\begin{array}{l}\text { Mexico } \\
\text { Atlantic }\end{array}$ & $\begin{array}{l}\text { Cruz-Palacios and van } \\
\text { Tussenbroek } 2005\end{array}$ & Subtidal & $\mathrm{Tc}, \mathrm{Si}$ & $80 \times 80 \mathrm{~cm}$ & -4 to $+10 \mathrm{~cm}$ & $2 \mathrm{mo}$. & yes & no & no \\
\hline Southern Portugal & Cabaço and Santos 2007 & Subtidal & $\mathrm{Zn}$ & $12 \mathrm{~cm}$ dia core & $-2 \mathrm{~cm}$ to $+16 \mathrm{~cm}$ & $2 \mathrm{mo}$. & yes & no & no \\
\hline $\begin{array}{l}\text { North Carolina } \\
\text { Mediterranean }\end{array}$ & Mills and Fonseca 2003 & Subtidal & $\mathrm{Zm}$ & $15.2 \mathrm{~cm}$ dia core & 0 to $16 \mathrm{~cm}$ & $1 \mathrm{mo}$. & yes & no & no \\
\hline NE Spain & Manzanera et al. 1998 & Subtidal & Po & $33 \mathrm{~cm}$ dia core & 0 to $14 \mathrm{~cm}$ & $8 \mathrm{mo}$. & yes & no & no \\
\hline $\begin{array}{l}\text { NE Spain } \\
\text { Indo-West Pacific }\end{array}$ & Marba and Duarte 1994 & Subtidal & Cn seedlings & $5 \mathrm{~cm}$ dia core & 0 to $16 \mathrm{~cm}$ & $1 \mathrm{mo}$. & yes & no & no \\
\hline Phillipines & Duarte et al. 1997 & & Th, Ea, Cr, Cs, Hu, Si, Ho & $0.50 \mathrm{~m}^{2}$ & $0-16 \mathrm{~cm}$ & $10 \mathrm{mo}$. & yes & no & no \\
\hline Phillipines & Rollon et al. 1998 & Subtidal & $\mathrm{Ea}, \mathrm{Th}, \mathrm{Cr}, \mathrm{Si}, \mathrm{Hu}, \mathrm{Ho}$ & $0.25 \mathrm{~m}^{2}$ & Clearing & $26 \mathrm{mo}$. & yes & no & no \\
\hline Australia & Rasheed 2004 & Subtidal & $\mathrm{Hu}, \mathrm{Cr}, \mathrm{Cs}, \mathrm{Si}, \mathrm{Ho}$ & $0.25 \mathrm{~m}^{2}$ & Clearing & $26 \mathrm{mo}$. & yes & no & no \\
\hline Mozambique & Muth et al (this study) & High & $\mathrm{Hu}, \mathrm{Nz}, \mathrm{Cr}, \mathrm{Th}, \mathrm{Ho}$ & $0.25 \mathrm{~m}^{2}$ & -10 and $+10 \mathrm{~cm}$ & $20 \mathrm{mo}$. & yes & yes & yes \\
\hline Mozambique & Muth et al (this study) & Middle & $\mathrm{Th}, \mathrm{Hu}, \mathrm{Cr}, \mathrm{Tc}, \mathrm{Ho}$ & $0.25 \mathrm{~m}^{2}$ & -10 and $+10 \mathrm{~cm}$ & $21 \mathrm{mo}$. & yes & yes & yes \\
\hline Mozambique & Muth et al (this study) & Low & $\mathrm{Tc}, \mathrm{Si}, \mathrm{Cs}, \mathrm{Th}, \mathrm{Cr}, \mathrm{Hu}$ & $0.25 \mathrm{~m}^{2}$ & -10 and $+10 \mathrm{~cm}$ & $22 \mathrm{mo}$. & yes & yes & yes \\
\hline
\end{tabular}

Appendix 3.1. Literature review on the response of seagrass communities to experimental sediment burial and removal. 


\begin{tabular}{|c|c|c|c|c|c|c|}
\hline PHYLUM & CLASS & FAMILY & Genus species & Upper & Middle & Lower \\
\hline \multirow[t]{35}{*}{ Mollusca } & Bivalvia & Arcidae & Anadara natalensis & & & $x$ \\
\hline & & & Arca sp. & & & $x$ \\
\hline & & Cardiidae & Cardium sp. & & & $x$ \\
\hline & & & Trachycardium flavum & & & $x x$ \\
\hline & & & Trachycardium sp. & & & $\mathrm{x}$ \\
\hline & & Donacidae & Donax sp. & & $x$ & \\
\hline & & Mactridae & Meropesta nicobarica & $x$ & $x$ & $x$ \\
\hline & & Mytilidae & Modiolus auriculatus & & & $x$ \\
\hline & & & Modiolus ligneus & & & $x$ \\
\hline & & & Modiolus philippinarum & & & $x$ \\
\hline & & & Modiolus sp. & & $x x$ & $x x$ \\
\hline & & & Septifer bilocularis & & & $x$ \\
\hline & & & Unidentified sp. & & $x$ & \\
\hline & & Pinnidae & Atrina vexillum & & & $x$ \\
\hline & & & Pinna muricata & & $x x$ & $x$ \\
\hline & & Psammobiidae & Hiatula sp. & & & $x$ \\
\hline & & Pteriidae & Pinctada capensis & & & $x$ \\
\hline & & & Pinctada margaritifera & & & $x$ \\
\hline & & & Pinctada nigra & & & $x$ \\
\hline & & & Unidentified sp. & & $x$ & $x$ \\
\hline & & Solenidae & Solen solanii & & & $x$ \\
\hline & & Tellinidae & Dosinia sp. & $x$ & & \\
\hline & & & Tellina sp. & $x$ & & $x$ \\
\hline & & Veneridae & Gafrarium divaricatum & & & $x x$ \\
\hline & & & Gafrarium pectinatum & & & $x$ \\
\hline & & & Lioconcha sp. & & & $x$ \\
\hline & & & Meretrix sp. & & & $\mathrm{x}$ \\
\hline & & & Tapes sp. & & & $x$ \\
\hline & & & Unidentified sp. & & & $x$ \\
\hline & & Unidentified & Unidentified sp. & $x$ & $x$ & $x$ \\
\hline & Gastropoda & Aplysiidae & Dolabella sp. & & $x^{*}$ & $\mathrm{X}^{*}$ \\
\hline & & Conidae & Conus sp. & & $X^{*}$ & $\mathrm{X}^{*}$ \\
\hline & & Cypraeidae & Cypraea annulus & $x$ & $x x$ & \\
\hline & & Nassariddae & Nassarius sp. & & $x$ & \\
\hline & & Trochidae & Unidentified sp. & & & \\
\hline \multirow[t]{5}{*}{ Sipuncula } & Phascolosomatidae & Aspidosiphonidae & Unidentified sp. & $x$ & $\bar{x}$ & $x$ \\
\hline & & Phascolosomatidae & Unidentified sp. & & & $\mathrm{x}$ \\
\hline & Sipunculidae & Sipunculidae & Siphonosoma sp. & $x$ & & \\
\hline & & & Sipunculus sp. & & & $x$ \\
\hline & & & Unidentified sp. & & $x x$ & $x$ \\
\hline \multirow[t]{15}{*}{ Annelidae } & Polychaeta & Amphinomidae & Unidentified sp. & & $x$ & \\
\hline & & Capitellidae & Notomastus sp. & & $x$ & $x$ \\
\hline & & & Unidentified sp. & & $x x$ & $x$ \\
\hline & & Cirratulidae & Unidentified sp. & $x$ & $x$ & \\
\hline & & Eunicidae & Unidentified sp. & $x$ & $x$ & $x$ \\
\hline & & Glyceridae & Unidentified sp. & & $x$ & $x$ \\
\hline & & Nephtyidae & Unidentified sp. & $x$ & $x$ & $x$ \\
\hline & & Nereididae & Unidentified sp. & $x$ & $x x$ & $x$ \\
\hline & & Opheliidae & Unidentified sp. & & $x$ & \\
\hline & & Phyllodocidae & Unidentified sp. & $x$ & $x$ & $x$ \\
\hline & & Serpulidae & Unidentified sp. & & $x$ & $x$ \\
\hline & & Spionidae & Unidentified sp. & & $x$ & $x$ \\
\hline & & Syllidae & Unidentified sp. & & & $x$ \\
\hline & & Unidentified & Unidentified sp. & $x$ & $x x$ & $x x$ \\
\hline & & & Unidentified sp. & & $x$ & $x$ \\
\hline
\end{tabular}




\begin{tabular}{|c|c|c|c|c|c|c|}
\hline PHYLUM & CLASS & FAMILY & Genus species & Upper & Middle & Lower \\
\hline \multirow[t]{20}{*}{ Arthropoda } & Malacostraca & Alpheidae & Alpheus sp. & $\mathrm{x}$ & $x$ & $x$ \\
\hline & & & Alpheus sp. & $x$ & & $x$ \\
\hline & & & Unidentified sp. & $x$ & & $x$ \\
\hline & & Diogenidae & Calcinus sp. & & & $\mathrm{x}$ \\
\hline & & Gonodactylidae & Unidentified sp. & $\mathrm{x}$ & & \\
\hline & & Grapsidae & Unidentified sp. & & $\mathrm{x}$ & $\mathrm{x}$ \\
\hline & & Hippolytidae & Unidentified sp. & $\mathrm{x}$ & $x$ & \\
\hline & & Mysidae & Unidentified sp. & & & $\mathrm{x}$ \\
\hline & & Ocypodidae & Dotilla Fenestrata & & & $x$ \\
\hline & & & Macrophthalmus grandidieri & $\mathrm{x}$ & & \\
\hline & & & Macrophthalmus nilloti & $x$ & & \\
\hline & & & Macrophthalmus sp. & $x$ & & \\
\hline & & & Ocypode sp. & & & $\mathrm{x}$ \\
\hline & & Palaemonidae & Unidentified sp. & & $x$ & $x$ \\
\hline & & Penaeidae & Unidentified sp. & & & $x$ \\
\hline & & Portunidae & Thalamita sp. & & & $x$ \\
\hline & & Squillidae & Unidentified sp. & & & $x$ \\
\hline & & Unidentified & Decapod & & $x$ & $x$ \\
\hline & & & Isopod & $x$ & $x$ & $x$ \\
\hline & & & Unidentified sp. & & $x$ & $\mathrm{x}$ \\
\hline \multirow[t]{18}{*}{ Echinodermata } & Asteroidea & Oreasteridae & Pentaceraster mammillatus & & & $\mathrm{X}^{*}$ \\
\hline & & & Protoreaster lincki & & $x$ & $x$ \\
\hline & Ophiuroidea & Amphiuridae & Amphiura & & & $x$ \\
\hline & & Ophiactidae & Ophiactis sp. & & & $x$ \\
\hline & & Ophiocomidae & Ophiocoma Sp. & & $\mathrm{x}$ & $x$ \\
\hline & Holothuroidae & Holothuriidae & Holothuria atra & & $\mathrm{X}^{*}$ & \\
\hline & & & Holothuria impatiens & & $\mathrm{X}^{*}$ & \\
\hline & & & Holothuria parva & $\mathrm{x}$ & & \\
\hline & & & Holothuria scabra & & $\mathrm{X}^{*}$ & \\
\hline & & & Unidentified sp. & $x$ & & \\
\hline & & Stichopodidae & Neostichopus grammatus & & $\mathrm{X}^{*}$ & \\
\hline & Echinoidea & Echinometridae & Echinometra mathaei & & $\mathrm{X}^{*}$ & $\mathrm{X}^{*}$ \\
\hline & & Toxopneustidae & Toxopneustes pileolus & & & $\mathrm{X}^{*}$ \\
\hline & & & Tripneustes gratilla & & $\mathrm{X}^{*}$ & $\mathrm{X}^{*}$ \\
\hline & & Diadematidae & Diadema savignyi & & $\mathrm{X}^{*}$ & $\mathrm{X}^{*}$ \\
\hline & & & Diadema setosum & & $\mathrm{X}^{*}$ & \\
\hline & & & Echinothrix diadema & & & $\mathrm{X}^{*}$ \\
\hline & & Cidaridae & Prionocidaris baculosa & & & \\
\hline Cnidaria & Anthozoa & Stichodactylidae & Stichodactyla haddoni & & $\mathrm{X}^{*}$ & $\mathrm{X}^{*}$ \\
\hline Chordata & Osteichthyes & Conger Eel & Unidentified sp. & & & $\mathrm{X}$ \\
\hline
\end{tabular}

Appendix 3.2. List of taxa present within different seagrass intertidal zones. The * denotes species that were observed within the experimental grid, but not collected in cores or incorporated in analysis. 


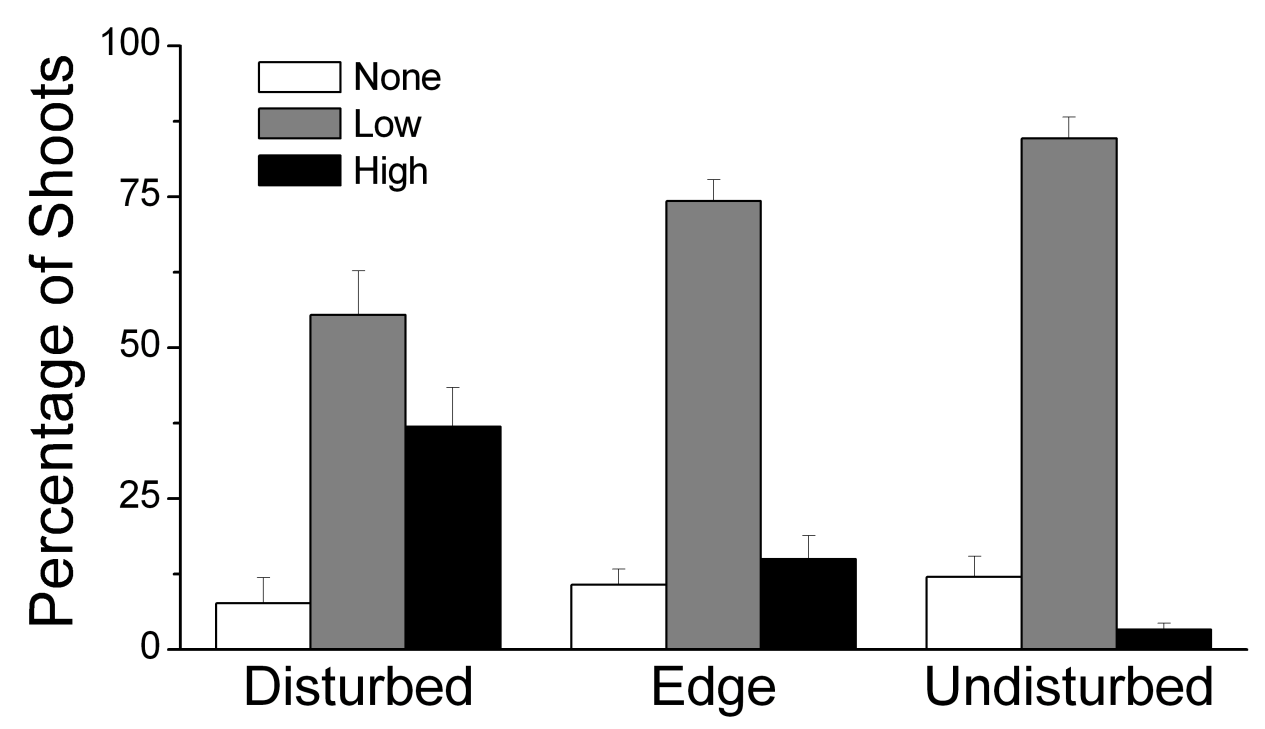

Appendix 3.3.a. Grazing intensity survey. Fifteen recently disturbed small-scale $(<1 \mathrm{~m}$ in width) gaps were randomly selected from the middle intertidal site. Relative grazing intensity for each shoot was recorded using a $10 \mathrm{~cm}$ x $20 \mathrm{~cm}$ quadrat placed inside the gap, along the edge, and within the seagrass. Relative grazing intensity (high $>25 \%$ biomass removed, low $<25 \%$ biomass removed, none $=$ no bite marks) was determined for each shoot inside the quadrats. Results: Grazing intensity was higher inside the bare gaps compared to adjacent undisturbed seagrass patches. 

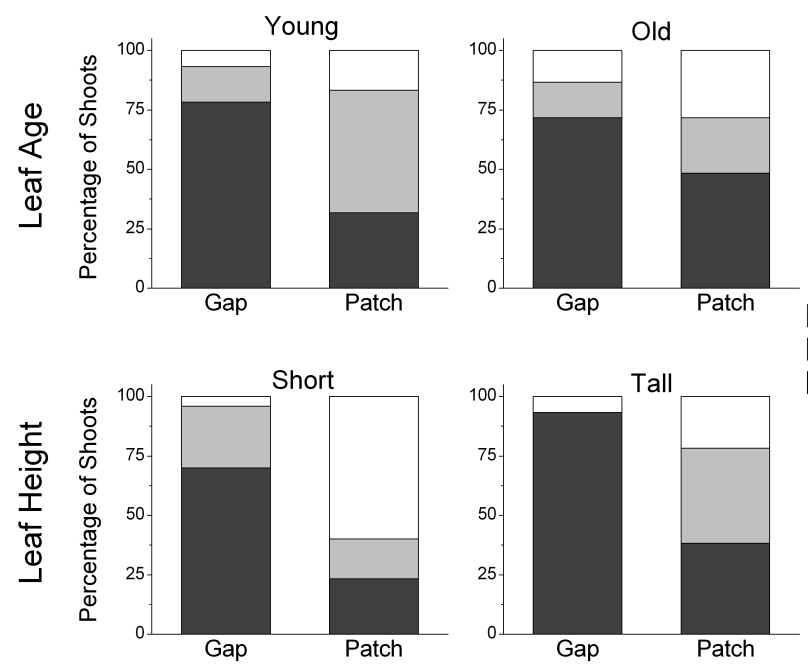

No Grazing
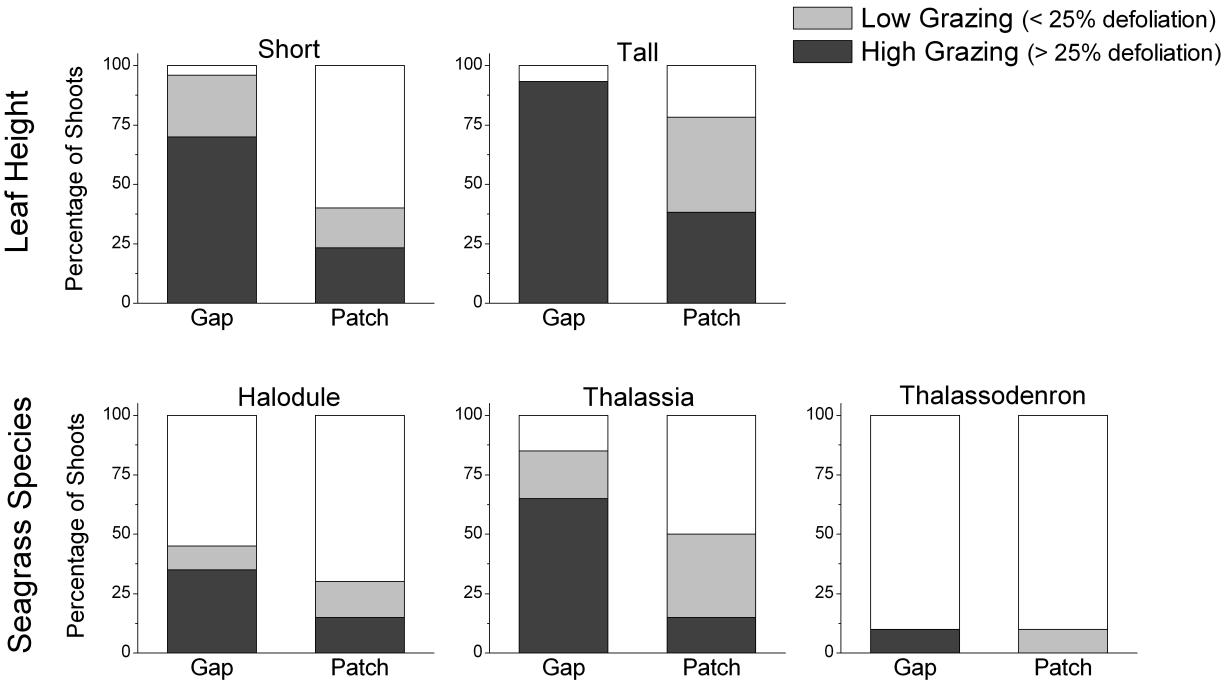

Appendix 3.3.b. Herbivory experiment. At the middle intertidal site, tethers $(2.5$ feet of nylon) with 6 seagrass shoots were placed within a bare disturbed gap and in an adjacent seagrass patches. Three tether treatments were chosen based on factors that may affect grazer preference: leaf age (young, old), shoot height (short, tall) and species $(H$. uninervis, T. hemprichii, T. ciliatum). Locations $(\mathrm{n}=2)$, treatment $(\mathrm{n}=3)$ and treatment replicates $(n=10)$ resulted in the use of 60 tethers for a total of 360 shoots used. Tethers were collected after three days and relative grazing intensity was estimated. Results: Grazing intensity was higher inside the bare gaps compared to adjacent seagrass patches. 


\title{
Chapter Four: Seagrass recovery following experimental changes in sediment organic content
}

\begin{abstract}
The effects of sediment organic content (SOC) on seagrass recovery following disturbance were examined at three mixed meadows located along a tidal gradient (upper, middle, lower) in the West Indian Ocean. Seagrass and sediment were excavated in-situ and plots were filled with sediment containing "High SOC"، $(5.6 \% \mathrm{dw})$, "Ambient SOC"، $(1.1-1.4 \% \mathrm{dw})$ or "Low SOC" $(0.64 \% \mathrm{dw})$ levels. The experimental design attempted to mimic ecologically realistic disturbance scenarios, where sediment was collected from nearby sources and the treatment plot size $(50 \mathrm{~cm}$ x $50 \mathrm{~cm})$ reflected a natural disturbance event. No lasting significant affects of SOC treatments were found on any sediment characteristics (organic content, porosity, redox potential) or seagrass parameters (shoot density, canopy height) after one year. The lack of a seagrass response to increased or decreased SOC may be related to the relatively short duration of the sediment organiccontent treatments; the added organic matter did not persist long enough to exert an effect. Detritus was often visible in the cleared disturbance plots and may have contributed to the rapid return to pre-disturbance sediment organic levels in the Low SOC treatment. The loss of organic matter in High SOC treatments cam be attributed to physical export of particles associated with increased resuspension following seagrass removal, and faster mineralization due to oxygen availability during exposure at low
\end{abstract}


tides. No differences between the three SOC treatments levels were observed within each site. Significant differences between seagrass removal treatment plots and control plots were only found when seagrass recolonization rates were slow: SOC was lower in all seagrass removal plots at the lower intertidal $(<15 \%$ shoot recovery of dominant Thalassodendron ciliatum), and redox potential was more negative in seagrass removal plots at the middle intertidal $(<10 \%$ shoot recovery of dominant Thalassia hemprichii). This study demonstrates that experimental manipulations of sediment organic content following seagrass removal in intertidal meadows does not produce effects that persist and therefore organic content may not be an important factor in small-scale recovery. These results differ markedly from experimental studies in subtidal seagrass habitats that found negative affects on seagrass growth. This study suggests that relationships between SOC and seagrass growth are site-specific and that factors other than sediment conditions regulates seagrass recovery in these tropical intertidal meadows.

\section{Introduction}

The global distribution of seagrasses is regulated largely by light availability (Duarte 1991), although numerous secondary factors may be locally important, including temperature, salinity, hydrodynamics (wave and currents), siltation and sediment characteristics (see Koch, 2001 for review). The sediment is important to submerged rooted macrophytes because it provides a substrate for anchoring and nutrients via root uptake (Barko and Smart 1986, Short 1987). Several sediment properties have been 
shown to have direct or indirect control on plant growth, including grain size and water content (Erftemeijer and Middelburg 1993, Bradley and Stolt 2006), porewater nutrients (Fourqurean et al. 1992), pH and redox potential (Terrados et al. 1999), and organic content (Matheson and Schwarz 2007). The presence of seagrass also creates a feedback to alter various physical, biological and chemical attributes of the plant communities; increased sediment retention and deposition, in conjunction with decreasing sediment suspension (Fonseca and Fisher 1986, Agawin and Duarte 2002), can increase the proportion of fine grain size particles, organic matter and nutrient content (Spivak et al. 2007 ) in the sediment. Exudation of dissolved organic matter from roots (Holmer et al. 2001) can modify the sediment redox potential through rhizosphere oxygenation (SandJensen et al. 1982, Pedersen et al. 1998, Enriquez et al. 2001) and increased mineralization and nutrient cycling within the sediment (see McGlathery et al., 2007 for review).

Sediment organic content (SOC) is a specific parameter that exerts a strong influence on microbial activity and biochemistry within the sediments (Holmer et al. 2004), and thus has the potential to both positively and negatively affect seagrass growth. Higher amounts of organic material can enhance mineralization, which in turn can increase the overall nutrient supply in a system. When nutrients are the limiting resource, leaf size and growth rates may increase with higher organic content levels (Lee et al. 2005, Wicks et al. 2009). However, excessive levels of SOC can be detrimental to plant growth and increase mortality through higher respiration rates that lead to reduced conditions and 
sulfide intrusion into roots. Literature reviews suggest that SOC greater than $5 \%$ can lead to negative seagrass impacts (Koch 2001). This phenomenon has been documented in both temperate and tropical species (Kenworthy et al. 1982, Goodman et al. 1995, Perez et al. 2007, Ruiz-Halpern et al. 2008, Mascaró et al. 2009) and can play a central role in large-scale seagrass die-off events (Carlson et al. 1994, Zieman et al. 1999, Koch et al. 2007). Negative effects of SOC on seagrass growth and recovery can linger (Eldridge et al. 2004), even after the initial loading source is terminated. For example, seagrass continued to decline for years following the cessation of high organic and nutrient loading from fish farms (Delgado et al. 1999, Cancemi et al. 2003), and recovery of $P$. oceanica meadows were slowed partly due to increased organic matter 18 years after beach replenishment (Gonzalez-Correa et al. 2008).

Disturbances that remove or damage seagrass plants can both increase and decrease sediment organic content. For example, large storm events such as hurricanes can remove or smother seagrasses with low SOC infertile sediment that can return the area to an early successional state (Birch and Birch 1984), in which recovery may be limited by nutrient deficiency from the lack of SOC. However, these disturbances can also transfer detrital material into bare areas that may elevate SOC and reduce seagrass recolonization rates.

Efforts to predict and model seagrass recovery following disturbance are hindered by the lack of data on what underlying factors may inhibit or facilitate seagrass recolonization. Because of the tight coupling between seagrass growth and sediment conditions, and 
because both high and low levels of SOC have been linked to delayed seagrass recovery, assessing how SOC affects recolonization after disturbances can be useful in our understanding of seagrass disturbance ecology. The overall objective of this project was to determine if sediment organic content could affect community recovery patterns following experimental seagrass removal designed to mimic small-scale disturbances in intertidal tropical mixed meadows. To address this goal, bare gaps were created within seagrass meadows, filled with sediment containing different levels of organic matter, and monitored for one year. The experimental size $(0.5 \mathrm{~m} \times 0.5 \mathrm{~m})$ reflects the principal disturbance activity resulting from natural disturbances such as bioturbation and hydrodynamics that are common in these intertidal zones. The specific objectives of this study is to (1) identify how changes in organic content of the sediment affect seagrass recovery, and (2) determine if any resulting recovery patterns differ based on tidal placement along a depth gradient.

\section{Methodology}

A 12-month in-situ manipulation of disturbance and sediment organic content was conducted in three different seagrass assemblages found along an Indo-West Pacific intertidal gradient. Study sites were on Inhaca Island $\left(25^{\circ} 58^{\prime}\right.$ and $26^{\circ} 05^{\prime} \mathrm{S}, 32^{\circ} 55^{\prime}$ and 33

${ }^{\circ} 00^{\prime} \mathrm{E}$ ) located on the east coast of southern Mozambique (Figure 4.1). Inhaca's shoreline ( $\sim 60 \mathrm{~km}^{2}$ in length) contains extensive intertidal zones of which nearly $50 \%$ are seagrass meadows (Bandeira 2002), and exhibits diurnal tides ranging from 0.1 to $3.9 \mathrm{~m}$. Three 
intertidal sites ("upper intertidal", "middle intertidal", "lower intertidal") were selected that represented seagrass assemblages unique to specific tidal zones throughout Mozambique and other Indo-Pacific locales. The upper intertidal site was on a shallow bank and dominated by Halodule uninervis and Nanozostera capensis, with Thalassia hemprichii and Cymodocea rotundata present. The middle intertidal was $T$. hemprichii dominant, with H. uninervis at lower densities and sparse Thalassodendron ciliatum. The lower intertidal site was similar to nearby subtidal communities with $T$. ciliatum dominant, and Cymodocea serrulata, T. hemprichii, H. uninervis and Syringodium isoetifolium present at lower densities. Halophila ovalis was present but sparse at all sites and exhibited high seasonality.

At each of the three sites, a grid of twenty-four $50 \mathrm{~cm}$ x $50 \mathrm{~cm}$ plots was created with 2.5 $\mathrm{m}$ separation between plots. The $0.25 \mathrm{~m}^{2}$ experimental size and sediment depth were selected based on results of an extensive preliminary survey of 305 sites on Inhaca that found small-scale $\left(<0.25 \mathrm{~m}^{2}\right)$ disturbances to be the most common form of disturbance in the intertidal seagrass meadows (Chapter 2). This choice of plot size also allows for direct data comparison with other organic enrichment studies that used the same experimental size (Terrados et al. 1999, Perez et al. 2007). All seagrass biomass and sediment were gently removed from each plot to a depth of $10 \mathrm{~cm}$ and replaced with one of three sediment treatments: "High SOC", "Ambient SOC", and "Low SOC”. Sediment for the High SOC $(5.63 \% \mathrm{dw})$ was collected from nearby mangroves, Ambient SOC sediment was collected from the excavated plot after removing plant material (range from 
1.12 to $1.36 \% \mathrm{dw})$ and Low SOC sediment $(0.63 \% \mathrm{dw})$ was collected from adjacent sand flats (Table 4.1). Macrofauna and detritus were removed from all sediment using a 3 $\mathrm{mm}$ sieve prior to application. The sediment sources for the "High" and "Low" SOC treatments were chosen because they represent the most ecologically realistic scenario of what would fill in cleared gaps via normal hydrological movement. In addition, the High SOC treatment is similar to organic-rich sediments described in related studies (Wicks et al. 2009), and exceeds the 5\% suggested threshold of sediment organic content for seagrass (Barko and Smart 1986) (Koch 2001). Non-disturbed non-treated vegetated plots were included as a Control treatment. There were 6 replicates of each of the three treatments plus controls at each of the 3 intertidal sites, for a total of 72 plots.

The experiment began in July 2006. Seagrass and sediment data were collected from each plot before seagrass removal, and subsequently at 3, 8, and 12 months. One sediment core (10 cc, $1.35 \mathrm{~cm} \mathrm{id,} 3 \mathrm{~cm}$ depth) was used to analyze sediment porosity and organic content during each sampling. Sediments were collected in pre-weighed containers, wet weight was calculated, and the sample was dried for 48 hours to obtain a dry weight. Organic content analysis was calculated as \% loss on ignition using an aliquot of each sample (ca. $5 \mathrm{~g}$ ) and combustion at $500{ }^{0} \mathrm{C}$ for 6 hours. Porewater was collected (Berg and McGlathery 2001) from each plot at depths representing the approximate location of the rhizosphere for the dominant species that were based on preliminary belowground biomass measurements; $5 \mathrm{~cm}$ at upper intertidal , $10 \mathrm{~cm}$ at middle and lower intertidal (Appendix 4.1). Redox potential (Eh) and $\mathrm{pH}$ of extracted porewater were measured 
immediately in-situ using double junction ORPTestr10 and phTestr10 (Oakton

instruments). Seagrass species-specific shoot density, canopy height ( $80 \%$ of tallest leaf) and visible sexual seagrass output were recorded. A digital photograph of every plot was collected at each sampling event.

Data were transformed when necessary to meet assumptions of variance and normality. One-way analysis of variance (ANOVA) was conducted to test for significant differences between the sediment treatments at each site for all parameters of seagrass (shoot density, canopy height) and sediment (organic content, porosity, redox potential). When a significant effect of the organic sediment treatment was found $(p \leq 0.05)$, differences between treatments were identified using Tukey's Honestly Significant Difference Test.

\section{Results}

\section{Site Characteristics and Sediment Additions}

The three sites (upper, middle, and lower intertidal) corresponded to environmental conditions representative of an intertidal gradient, in which standing water increased and length of time that plant material was exposed to air decreased with depth (Table 4.2). Mean water temperatures within the canopy were similar between sites, but the upper intertidal sites experienced the greatest range of values $\left(10.8-46.5{ }^{0} \mathrm{C}\right)$. Composition of sediments varied, such that the upper intertidal had the smallest grain size and lowest 
organic content $(1.04 \% \mathrm{dw} \pm 0.03)$, and the lower intertidal had the larger grain size and highest organic content $(1.25 \% \mathrm{dw} \pm 0.09)$ (Table 4.1 and 4.2$)$. The lower intertidal site was dominated by large-sized species with extensive below-ground biomass (T. ciliatum) and more positive redox potential values compared to the upper site that was dominated by smaller-sized species with reduced below-ground biomass (H. uninervis) and more negative redox potential values. The middle intertidal was dominated by the mid-sized seagrass $T$. hemprichii.

At the start of the experiment, the High SOC treatment plots had higher organic (5.63\% $\pm 0.62)$, nitrogen $(0.49 \% \mathrm{dw} \pm 0.02)$ and phosphorus $(0.046 \% \mathrm{dw} \pm 0.001)$ content compared to the Low SOC treatment, which had the lowest organic $(0.461 \% \mathrm{dw} \pm 0.02)$, nitrogen $(<0.01)$ and phosphorus $(<0.01)$ content. The organic content of the Ambient SOC treatment was similar in the upper intertidal ( $1.04 \% \mathrm{dw} \pm 0.03)$, middle intertidal $(1.21 \% \mathrm{dw} \pm 0.05)$ and lower intertidal $(1.25 \% \mathrm{dw} \pm 0.09)$, and these values were all between the High SOC and Low SOC treatments. Porewater nutrient values for the Ambient SOC treatments varied between sites and were less for the upper intertidal ( $\% \mathrm{~N}$ $=0.13 \pm 0.02 ; \% \mathrm{P}=0.002 \pm<0.01)$ compared to the middle intertidal $(\% \mathrm{~N}=0.73 \pm$ $0.13 ; \% \mathrm{P}=0.045 \pm 0.01)$ and lower intertidal $(\% \mathrm{~N}=0.81 \pm 0.23 ; \% \mathrm{P}=0.051 \pm<$ 0.01). Redox potential (Eh) values were more negative in the High SOC site originating from mangrove mud (-143.8) and more positive at the Low SOC site originating from beach sand $(+43)$. 


\section{Sediment}

Few lasting impacts were observed for sediment conditions following experimental seagrass removal and SOC treatment application (Figure 4.2). Organic content remained elevated in High SOC treatments only at the upper intertidal after three months $(\mathrm{F}=$ $16.45, p=<0.001)$, but this effect was gone for the remainder of the one-year study. No other significant differences between the treatment applications were found. Most sediment parameters returned to pre-disturbance levels after one year (Figure 4.3). Sediment treated plots were not significantly different from vegetated controls after one year except for a reduction in redox potential at the middle intertidal $(\mathrm{F}=7.36, p=0.002)$ and a reduction in organic content at the lower intertidal $(\mathrm{F}=5.90, p=0.005)$.

\section{Seagrass}

Rate of seagrass recolonization (based on shoot density) varied according to the intertidal site (Figure 4.4), but no significant differences were observed for shoot density between the three SOC disturbance treatments within each site. The upper intertidal recovered the fastest, with $H$. uninervis and $N$. capensis reaching pre-disturbance shoot density levels after one year in all SOC treatments. Cymodocea rotundata and T. hemprichii were also present at the upper intertidal, but were sparse and patchy in distribution. The middle and lower intertidal sites were both characterized by overall slower recovery rates compared to the upper intertidal. The dominant species at the middle intertidal, $T$. hemprichii, only reached $10 \%$ of its pre-disturbance shoot density levels at the end of the experiment, and the faster-growing $H$. uninervis had less than ca. 50\% recovery. C. rotundata (mean shoot 
density $\left.=3.3 \mathrm{~m}^{2}\right)$ and Thalassodendron ciliatum $\left(1.3 \mathrm{~m}^{2}\right)$ were present in some control plots but not found in any treatment plots after 1 year, and their density numbers were too low to make any conclusions based on statistical differences. At the lower intertidal, the slower-growing T. ciliatum recovered to only ca. $15 \%$ of pre-disturbance levels in all three SOC treatments. At the end of the experiment, S. isoetifolium was only found in experimental treatment plots although it exhibited high variability because its presence was not distributed equally between treatments and not found in every plot (Figure 4.5). Cymodocea rotundata and C. serrulata were also present at the lower intertidal, but shoot density trends could not be established because of sparse and patchy distribution. Both $T$. hemprichii at the middle intertidal $(\mathrm{F}=98.6, p<0.001)$ and $T$. ciliatum at the lower intertidal $(\mathrm{F}=29.3, p<0.001)$ had significantly lower shoot densities compared to vegetated control plots (Figure 4.5). No signs of sexual output or colonization were observed (e.g. seedlings), although a small number of flowers were identified on $T$. hemprichii. No macroalgae were found in the plots. Seagrass detrital material was observed in bare gaps, and persisted for a period ranging from days to months. Leaf height of newly-colonized shoots did not vary according to disturbance treatment, except at the upper intertidal during the first sampling event at 3 months $(\mathrm{F}=6.89, p=0.008)$ when H. uninervis leaf height was lower for the High SOC treatment (Figure 4.5). No lasting effects on seagrass leaf height were found at the end of the experiment (1 year). 


\section{Discussion}

Our data indicate that following a disturbance that results in seagrass and sediment removal, the organic content of replacement sediment has negligible effects on seagrass recovery for small-scale $\left(<1 \mathrm{~m}^{2}\right)$ disturbances in intertidal seagrass beds after several months. This contradicts other studies that have found marked and persistent (several months) responses in both sediment and seagrass status following SOC manipulation in subtidal zones (Perez et al. 2007). Effort was made to mimic natural disturbances by using treatment plots whose sizes reflected ecologically relevant disturbance regimes (anchor scars, bioturbation, wave energy etc.). Also, sources of sediment treatments were only obtained from sources that could potentially fill a recently disturbed excavation in the seagrass bed (adjacent mangrove mud and beach sand). The ranges of sediment organic content and other parameters within our investigation were consistent with levels used in other seagrass habitats (Koch 2001). A threshold of $5 \%$ sediment organic matter beyond which seagrass growth declines has been suggested (Barko and Smart 1986). Subsequent literature reviews generally support this value (Koch 2001). None of the data used to establish this threshold value represented studies of tropical intertidal IndoPacific species, but they did include co-generic tropical Caribbean species (e.g. $T$. testudinum). Despite an initial High SOC application of $5.63 \%$ organic content that surpassed the estimated 5\% threshold, no differences in seagrass parameters were observed between Low, Ambient and High SOC treatments. 
The absence of a lasting seagrass response to increased or decreased SOC is related to the fact that our treatments - both the addition and reduction of organic content - did not persist long enough to see an effect. Several different mechanisms may be driving this phenomenon. With respect to Low SOC treatments, external organic matter may have contributed to the rapid return to pre-disturbance levels. Large amounts of detritus were frequently observed within treatment plots for a period ranging from days to months, with detrital material persisting the longest in the lower intertidal where the surrounding plants were larger and could effectively trap plant material in the un-vegetated plot. The small size of the plots further increase the likelihood that organic matter originating from adjacent seagrass detritus could settle and be incorporated into the disturbed bare sediment.

The rapid loss of organic content in the High SOC treatments was unexpected. There was some evidence from short-term observations that elevated organic concentrations were inhibiting seagrass growth. This inhibition was demonstrated by a significant decrease in canopy height at 3 months for H. uninervis at the upper intertidal, but this trend did not last. The loss of organic content in high SOC treatments may be attributed to the shallow intertidal nature of our sites. Specifically, air exposure during low tide may have increased oxygen availability to the sediment directly (Holmer et al. 1999), or indirectly by abundant bioturbation activity of organisms (e.g. bivalves, sea cucumbers) found throughout the intertidal zones (Chapter 2). Such oxygenation of the sediment can accelerate mineralization and decomposition rates, thus decreasing initial SOC 
concentrations. A second possible reason that could explain the rapid loss of SOC concentrations is that bare sediments are more prone to resuspension than are seagrass inhabited areas (Terrados and Duarte 2000). The result would be an increase in the export of both particulate and dissolved organic matter out of the disturbance plot and an increase in oxygen delivery. While resuspension is common in both subtidal and intertidal zones, wave and tidal action can physically impact the intertidal benthos more directly than the subtidal benthos (Nielsen 1982). These environmental conditions increased oxygen exposure within the intertidal zone due to exposure and sediment instability due to seagrass removal, combined with increased magnitude of wave action in the intertidal- distinguish this investigation from other organic enrichment studies that have only been conducted in vegetated subtidal habitats (Terrados et al. 1999, Perez et al. 2007, Ruiz-Halpern et al. 2008, Wicks et al. 2009), and may also help explain why SOC enrichment did not persist.

If the loss of added SOC was indeed related to increased mineralization following increased oxygen delivery in the intertidal zone, then a pulse of nutrients could have resulted in a seagrass response. Seagrasses are able to take up nutrients from both the sediment and water column (Hemminga et al. 1991), but sediment nutrients from SOC are especially important in tropical regions with oligotrophic waters and may help ameliorate both seagrass nutrient limitation (Short 1987) and competition between bacteria and seagrasses for the added nutrient supply (Terrados et al. 1999). Perez et al. (2007) found that the combination of SOC and nutrients together produced a stronger 
negative seagrass response than singular treatments, highlighting the role of nutrient status in the overall response to organic enrichment. Porewater nutrients were not collected in this study over a time scale that would be relevant to identifying a direct linkage between SOC addition and nutrient availability for enhanced seagrass growth. However, there is circumstantial evidence that nutrients were not likely limiting growth based on relatively high plant tissue nutrient content levels and the absence of seagrass responses to a 20-month nitrogen and phosphorus enrichment at the same sites used in this study (Appendix 2.4).

Although no evidence suggests that SOC can affect seagrass recovery or change the competitive dominance in mixed species beds, our results do support previously reported linkages between seagrass and sediment recovery patterns. Sites with slower recovery (middle and lower intertidal) were more likely to exhibit some type of sediment response: SOC was lower in all three seagrass removal plots compared to vegetated control plots at the lower intertidal ( $<15 \%$ shoot recovery of dominant Thalassodendron ciliatum), and redox potential was more negative in seagrass removal plots compared to vegetated control plots at the middle intertidal $(<10 \%$ shoot recovery of dominant Thalassia hemprichii). Decreases in SOC following plant removal may have been a result of decreased organic matter input via plant mortality and defoliation. There may also have been a loss in the plant's sediment trapping ability that would normally increase sedimentation and organic matter input (Agawin and Duarte 2002). Sediment trapping is particularly important at the lower intertidal where the mean canopy height (T. ciliatum 
$=14.6 \mathrm{~cm})$ was almost twice that of the middle $($ T. hemprichii $=80 \mathrm{~cm})$ and lower $(H$. uninervis $=76 \mathrm{~cm}$ ) intertidal dominants. The absence of seagrasses in the lower intertidal one year after seagrass removal may have provided a positive feedback of SOC loss over time.

Our organic-enriched sediments did not induce reducing conditions in test plots that were strong enough to negatively impact seagrass recovery, nor enough to significantly affect reducing conditions between SOC treatments. The overall negative redox values of the porewater within our study sites appear to be representative of other systems since they support dense, healthy seagrass in the controls and are comparable to those found in other seagrass meadows (Terrados et al. 1999, Enriquez et al. 2001, Peralta et al. 2003). A significant decrease in redox values (ca. $-150 \mathrm{mV}$ ) was observed at the middle intertidal for all SOC disturbance treatments. The middle intertidal site did exhibit slow recovery rates (ca. $10 \%$ shoot density of the dominant $T$. hemprichii) compared to the $50 \%$ recovery rates observed for the same species in other studies (Rollon et al. 1998). This slow recovery was not likely related directly to the reduced redox values because the lower intertidal also had low recovery rates but did not exhibit any changes in sediment redox potential. It is also not uncommon for bare sediments to have reduced redox values compared to adjacent seagrass (Zieman 1976, Marba et al. 2010), although the mechanism is probably not related to plant removal. This conclusion is based on evidence showing that rhizosphere oxygenation occurs only within a small distance (few $\mathrm{mm}$ ) around the root tip (Frederiksen and Glud 2006). 
This study used sediment organic sources and concentrations (5.6\% SOC) that could mimic naturally occurring disturbance scenarios. The only other published study where natural sediment sources were used to manipulate experimentally SOC concentrations was by Wicks et al. (Wicks et al. 2009), who found levels up to 6\% SOC produced no negative seagrass effects in mesocosms of the temperate seagrass Zostera marina. Studies that have observed negative seagrass effects following SOC enrichment used high loading rates that were delivered repeatedly over time, such as $800 \mathrm{~g}$ of sucrose added weekly (Perez et al. 2007) and $16 \mathrm{~g} \mathrm{C} \mathrm{m}^{-2}$ per day (Terrados et al. 1999). The persistence and impact of SOC levels can be further affected by numerous factors that were not measured in this study, including the quality of SOC (e.g. carbon lability), bacterial community composition (Milbrandt et al. 2008), higher trophic level effects such as bioturbation (Bastyan and Cambridge 2008) and grazing (Canuel et al. 2007), local hydrodynamic conditions (Wicks et al. 2009), iron concentrations (Holmer et al. 2005), species-specific attributes (Fonseca and Fisher 1986) and light (Eldridge et al. 2004, Moore 2004).

Our investigation focused on small-scale disturbance events, which can be important at local scales (Sargent et al. 1995, Duarte et al. 1997)(Chapter 2), but may be less applicable to larger or more severe disturbances. For example, the depth of the disturbance can impact sediment conditions and recovery time. Hammerstrom et al. (2007) created experimentally small-scale vessel damage scars $(50 \mathrm{~cm} \times 150 \mathrm{~cm})$ and 
found that disturbances greater than $20 \mathrm{~cm}$ deep resulted in longer recovery than shallow disturbances less than $10 \mathrm{~cm}$, which was the depth of this study. Larger disturbances such as storm and die-off events tend to rely more on sexual reproduction during recovery (Greve et al. 2005, Kirsch et al. 2005) and the success of new colonization via seedlings may be increased with more organic-rich sediment (van Katwijk and Wijgergangs 2004). No seedlings were observed in the small-scale plots. Large-sized disturbances that create extensive areas of exposed substrate are also more prone to subsequent disturbances (Whitfield et al. 2002) that can further alter sediment conditions.

This study demonstrated that sediment organic enrichment and depletion following seagrass removal in intertidal meadows do not persist and thus may not be important factors in small-scale recovery. These results differ markedly from other sediment organic enrichment studies in vegetated subtidal environments and suggest that mechanisms unique to both the intertidal environment and seagrass removal will influence the relative importance of sediment organic content on seagrass recolonization following small-scale disturbances. While our data did not show any effects of SOC on seagrass recovery, several studies have demonstrated that additional sediment factors such as composition and texture (Kenworthy and Fonseca 1977, Balestri et al. 1998, Park and Lee 2007) and nutrient content (Kenworthy and Fonseca 1977, Peralta et al. 2003, Kaldy et al. 2004, Cambridge and Kendrick 2009) can play an important role in both natural recovery and artificial restoration processes. With seagrass decline on the rise, and with interest in seagrass restoration practices as a means to mediate global and 
local seagrass decline, more information on sediment processes following disturbance is required to predict and delineate optimal seagrass recovery conditions. 


\section{References}

Agawin, N. S. R. and G. M. Duarte. 2002. Evidence of direct particle trapping by a tropical seagrass meadow. Estuaries 25: 1205-1209.

Balestri, E., L. Piazzi, and F. Cinelli. 1998. Survival and growth of transplanted and natural seedlings of Posidonia oceanica (L.) Delile in a damaged coastal area. Journal of Experimental Marine Biology and Ecology 228: 209-225.

Bandeira, S., 2002. Diversity and distribution of seagrasses around Inhaca Island, southern Mozambique. South African Journal of Botany 68: 191-198.

Barko, J. W. and M. Smart. 1986. Sediment-related mechanisms of growth limitation in submersed macrophytes. Ecology 1328-1340.

Bastyan, G. R. and M. L. Cambridge. 2008. Transplantation as a method for restoring the seagrass Posidonia australis. Estuarine Coastal Shelf Science 79: 289-299.

Berg, P. and K. J. McGlathery. 2001. A high-resolution pore water sampler for sandy sediments. Limnology and Oceanography 46: 203-210.

Birch, W. R. and M. Birch. 1984. Succession and pattern of tropical intertidal seagrasses in Cockle Bay, Queensland, Australia: A decade of observations. Aquatic Botany 19: 343-367.

Bradley, M. P. and M. H. Stolt. 2006. Landscape-level seagrass-sediment relations in a coastal lagoon. Aquatic Botany 84: 121-128.

Cambridge, M. L. and G. A. Kendrick. 2009. Contrasting responses of seagrass transplants (Posidonia australis) to nitrogen, phosphorus and iron addition in an estuary and a coastal embayment. Journal of Experimental Marine Biology and Ecology 371: 34-41.

Cancemi, G., G. De Falco, and G. Pergent. 2003. Effects of organic matter input from a fish farming facility on a Posidonia oceanica meadow. Estuarine Coastal Shelf Science 56: 961-968.

Canuel, E. A., A. C. Spivak, E. J. Waterson, and J. E. Duffy. 2007. Biodiversity and food web structure influence short-term accumulation of sediment organic matter in an experimental seagrass system. Limnology and Oceanography 52: 590-602.

Carlson, P. R., L. A. Yarbro, and T. R. Barber. 1994. Relationship of sediment sulfide to mortality of Thalassia testudinum in Florida Bay. Bulletin of Marine Science 54: 733-746.

Delgado, O., J. Ruiz, M. Perez, J. Romero, and E. Ballesteros. 1999. Effects of fish farming on seagrass (Posidonia oceanica) in a Mediterranean bay: seagrass decline after organic loading cessationgonz. Oceanologica Acta 22: 109-117.

Duarte, C. M., 1991. Seagrass depth limits. Aquatic Botany 40: 363-377.

Duarte, C. M., J. Terrados, N. S. R. Agawin, M. D. Fortes, S. Bach, and W. J. Kenworthy. 1997. Response of a mixed Philippine seagrass meadow to experimental burial. Marine Ecology Progress Series 147: 285-294. 
Eldridge, P. M., J. E. Kaldy, and A. B. Burd. 2004. Stress response model for the tropical seagrass Thalassia testudinum: The interactions of light, temperature, sedimentation, and geochemistry. Estuaries 27: 923-937.

Enriquez, S., N. Marba, C. M. Duarte, B. I. van Tussenbroek, and G. Reyes-Zavala. 2001. Effects of seagrass Thalassia testudinum on sediment redox. Marine Ecology Progress Series 219: 149-158.

Erftemeijer, P. L. A. and J. J. Middelburg. 1993. Sediment-nutrient interactions in tropical seagrass beds: a comparison between a terrigenous and a carbonate sedimentary environment in South Sulawesi (Indonesia). Marine Ecology Progress Series 102: 187-198.

Fonseca, M. S. and J. S. Fisher. 1986. A comparison of canopy friction and sediment movement between 4 species of seagrass with reference to their ecology and restoration. Marine Ecology Progress Series 29: 15-22.

Fourqurean, J. W., J. C. Zieman, and G. V. N. Powell. 1992. Relationships between porewater nutrients and seagrasses in a subtropical carbonate environment. Marine Biology 114: 57-65.

Frederiksen, M. S. and R. N. Glud. 2006. Oxygen dynamics in the rhizosphere of Zostera marina: A two-dimensional planar optode study. Limnology and Oceanography 51: 1072-1083.

Gonzalez-Correa, J. M., Y. F. Torquemada, and J. L. S. Lizaso. 2008. Long-term effect of beach replenishment on natural recovery of shallow Posidonia oceanica meadows. Estuarine Coastal Shelf Science 76: 834-844.

Goodman, J. L., K. A. Moore, and W. C. Dennison. 1995. Photosynthetic responses of eelgrass (Zostera marina $\mathrm{L}$ ) to light and sediment sulfide in a shallow barrier island lagoon . Aquatic Botany 50: 37-47.

Greve, T. M., D. Krause-Jensen, M. B. Rasmussen, and P. B. Christensen. 2005. Means of rapid eelgrass (Zostera marina $L$.) recolonisation in former dieback areas. Aquatic Botany 82: 143-156.

Hemminga, M. A., P. G. Harrison, and F. Vanlent. 1991. The balance of nutrient losses and gains in seagrass meadows. Marine Ecology Progress Series 71: 85-96.

Holmer, M., C. M. Duarte, and N. Marba. 2005. Iron additions reduce sulfate reduction rates and improve seagrass growth on organic-enriched carbonate sediments. Ecosystems 8: 721-730.

Holmer, M., C. M. Duarte, H. T. S. Boschker, and C. Barron. 2004. Carbon cycling and bacterial carbon sources in pristine and impacted Mediterranean seagrass sediments. Aquatic Microbial Ecology 36: 227-237.

Holmer, M., F. O. Andersen, N. Holmboe, E. Kristensen, and N. Thongtham. 1999. Transformation and exchange processes in the Bangrong mangrove forestseagrass bed system, Thailand. Seasonal and spatial variations in benthic metabolism and sulfur biogeochemistry. Aquatic Microbial Ecology 20: 203-212.

Holmer, M., F. O. Andersen, S. L. Nielsen, and H. T. S. Boschker. 2001. The importance of mineralization based on sulfate reduction for nutrient regeneration in tropical seagrass sediments. Aquatic Botany 71: 1-17. 
Kaldy, J. E., K. H. Dunton, J. L. Kowalski, and K. S. Lee. 2004. Factors controlling seagrass revegetation onto dredged material deposits: A case study in Lower Laguna Madre, Texas. Journal of Coastal Research 20: 292-300.

Kenworthy, W. J. and M. Fonseca. 1977. Reciprocal transplant of seagrass Zostera marina L effect of substrate on growth . Aquaculture 12: 197-213.

Kenworthy, W. J., J. C. Zieman, and G. W. Thayer. 1982. Evidence for the influence of seagrasses on the benthic nitrogen cycle in a coastal plain estuary near Beaufort, North Carolina (USA). Oecologia 54: 152-158.

Kirsch, K. D., K. A. Barry, M. S. Fonseca, P. E. Whitfield, S. R. Meehan, W. J. Kenworthy, and B. E. Julius. 2005. The mini-312 program - An expedited damage assessment and restoration process for seagrasses in the Florida Keys National Marine Sanctuary. Journal of Coastal Research 109-119.

Koch, E. M., 2001. Beyond light: Physical, geological, and geochemical parameters as possible submersed aquatic vegetation habitat requirements. Estuaries 24: -17 .

Koch, M. S., S. A. Schopmeyer, O. I. Nielsen, C. Kyhn-Hansen, and C. J. Madden. 2007. Conceptual model of seagrass die-off in Florida Bay: Links to biogeochemical processes. Journal of Experimental Marine Biology and Ecology 350: 73-88.

Lee, S. Y., J. H. Oh, C. I. Choi, Y. Suh, and H. Mukai. 2005. Leaf growth and population dynamics of intertidal Zostera japonica on the western coast of Korea. Aquatic Botany 83: 263-280.

Marba, N., C. M. Duarte, J. Terrados, Z. Halun, E. Gacia, and M. D. Fortes. 2010. Effects of seagrass rhizospheres on sediment redox conditions in SE Asian coastal ecosystems. Estuaries and Coasts 33: 107-117.

Mascaró, O., T. Valdemarsend, M. Holmer, M. Pérez, and J. Romero. 2009. Experimental manipulation of sediment organic content and water column aeration reduces Zostera marina (eelgrass) growth and survival. Journal of Experimental Marine Biology and Ecology 26*34.

Matheson, F. E. and A. M. Schwarz. 2007. Growth responses of Zostera capricorni to estuarine sediment conditions. Aquatic Botany 87: 299-306.

McGlathery, K. J., K. Sundback, and I. C. Anderson. 2007. Eutrophication in shallow coastal bays and lagoons: the role of plants in the coastal filter. Marine Ecology Progress Series 348: 1-18.

Milbrandt, E. C., J. Greenawalt-Boswell, and P. D. Sokoloff. 2008. Short-term indicators of seagrass transplant stress in response to sediment bacterial community disruption. Botanic Marina 51: 103-111.

Moore, K. A., 2004. Influence of seagrasses on water quality in shallow regions of the lower Chesapeake Bay. Journal of Coastal Research 162-178.

Nielsen, P., 1982. Coastal Bottom Boundary Layers and Sediment Transport. World Scientific.

Park, J. I. and K. S. Lee. 2007. Site-specific success of three transplanting methods and the effect of planting time on the establishment of Zostera marina transplants. Marine Pollution Bulletin 54: 1238-1248. 
Pedersen, O., J. Borum, C. M. Duarte, and M. D. Fortes. 1998. Oxygen dynamics in the rhizosphere of Cymodocea rotundata. Marine Ecology Progress Series 169: 283288.

Peralta, G., T. J. Bouma, J. van Soelen, J. L. Perez-Llorens, and I. Hernandez. 2003. On the use of sediment fertilization for seagrass restoration: a mesocosm study on Zostera marina L. Aquatic Botany 75: 95-110.

Perez, M., O. Invers, J. M. Ruiz, M. S. Frederiksen, and M. Holmer. 2007. Physiological responses of the seagrass Posidonia oceanica to elevated organic matter content in sediments: An experimental assessment. Journal of Experimental Marine Biology and Ecology 344: 149-160.

Rollon, R. N., E. D. D. Van Steveninck, W. Van Vierssen, and M. D. Fortes. 1998. Contrasting recolonization strategies in multi-species seagrass meadows. Marine Pollution Bulletin 37: 450-459.

Ruiz-Halpern, S., S. A. Macko, and J. W. Fourqurean. 2008. The effects of manipulation of sedimentary iron and organic matter on sediment biogeochemistry and seagrasses in a subtropical carbonate environment. Biogeochemistry 87: 113-126.

Sand-Jensen, K., C. Prahl, and H. Stockholm. 1982. Oxygen release from roots of submerged aquatic macrophytes. Oikos 349-354.

Sargent, F. J., T. J. Leary, D. W. Crewz, and C. R. Kruer. 1995. Scarring of Florida's Seagrasses: Assessment and Management. Florida Marine Research Institute Technical Report TR-1 .

Short, F. T., 1987. Effects of sediment nutrients on seagrasses: literature review and mesocosm experiment. Aquatic Botany 27: 41-57.

Spivak, A. C., E. A. Canuel, J. E. Duffy, and J. P. Richardson. 2007. Top-down and bottom-up controls on sediment organic matter composition in an experimental seagrass ecosystem. Limnology and Oceanography 52: 2595-2607.

Terrados, J. and C. M. Duarte. 2000. Experimental evidence of reduced particle resuspension within a seagrass (Posidonia oceanica L.) meadow. Journal of Experimental Marine Biology and Ecology 243: 45-53.

Terrados, J., C. M. Duarte, L. Kamp-Nielsen, N. S. R. Agawin, E. Gacia, D. Lacap, M. D. Fortes, J. Borum, M. Lubanski, and T. Greve. 1999. Are seagrass growth and survival constrained by the reducing conditions of the sediment? Aquatic Botany 65: 175-197.

Terrados, J., J. Borum, C. M. Duarte, M. D. Fortes, L. Kamp-Nielsen, N. S. R. Agawin, and W. J. Kenworthy. 1999. Nutrient and mass allocation of South-east Asian seagrasses. Aquatic Botany 63: 203-217.

van Katwijk, M. M. and L. J. M. Wijgergangs. 2004. Effects of locally varying exposure, sediment type and low-tide water cover on Zostera marina recruitment from seed. Aquatic Botany 80: 1-12.

Whitfield, P. E., J. W. Kenworthy, K. K. Hammerstrom, and M. S. Fonseca. 2002. The role of a hurricane in the expansion of disturbances initiated by motor vessels on seagrass banks. Journal of Coastal Research 86-99 . 
Wicks, E. C., E. W. Koch, J. M. O'Neil, and K. Elliston. 2009. Effects of sediment organic content and hydrodynamic conditions on the growth and distribution of Zostera marina. Marine Ecology Progress Series 378: 71-80.

Zieman, J. C., 1976. The ecological effects of physical damage from motor boats on turtle grass beds in Southern Florida. Aquatic Botany 127-139.

Zieman, J. C., J. W. Fourqurean, and T. A. Frankovich. 1999. Seagrass die-off in Florida Bay: Long-term trends in abundance and growth of turtle grass, Thalassia testudinum. Estuaries 22: 460-470. 


\section{Figures}

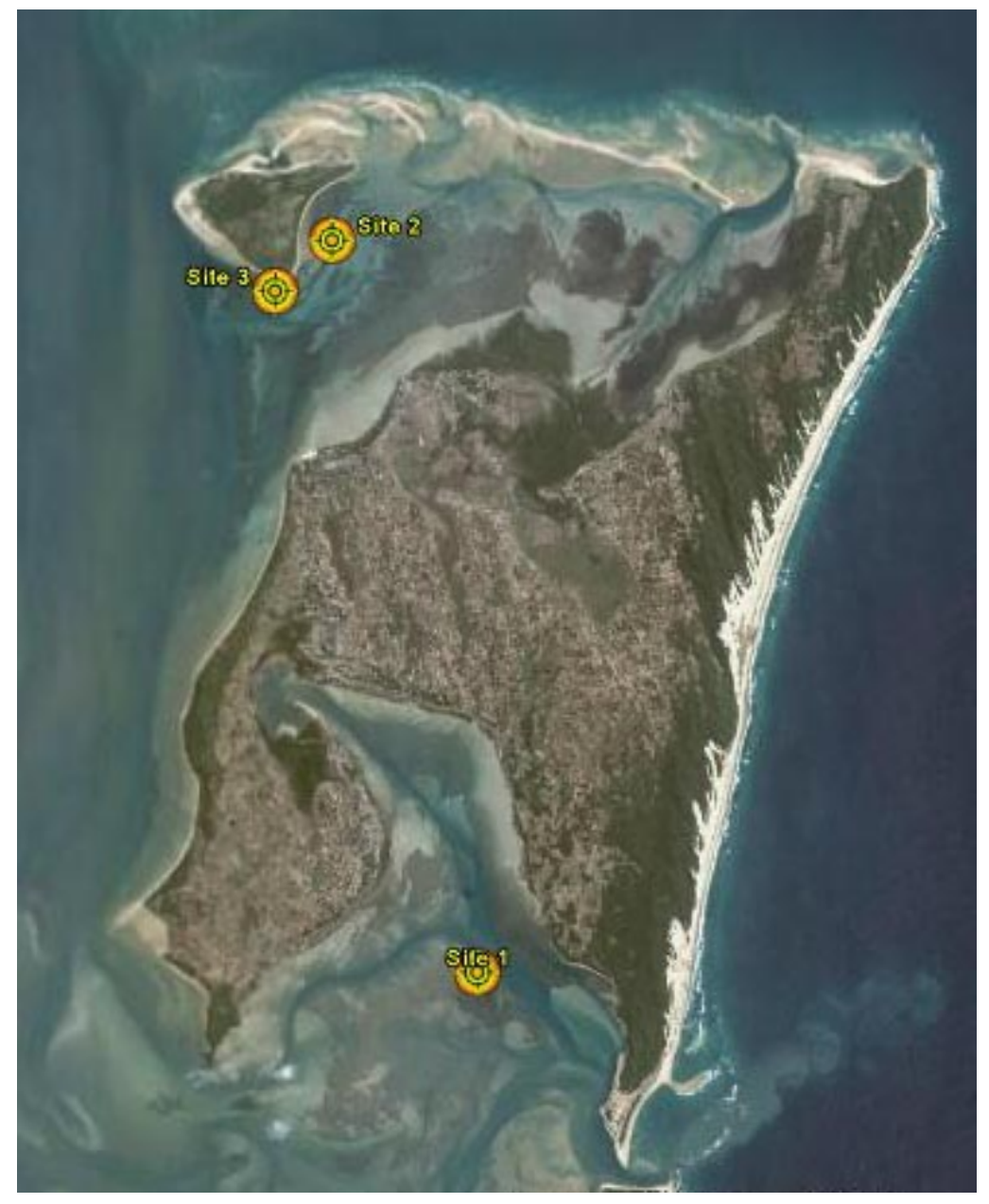

Figure 4.1. Map of Inhaca island and disturbance experiment sites.

Site $1=$ upper intertidal; Site $2=$ middle intertidal; Site $3=$ lower intertidal 

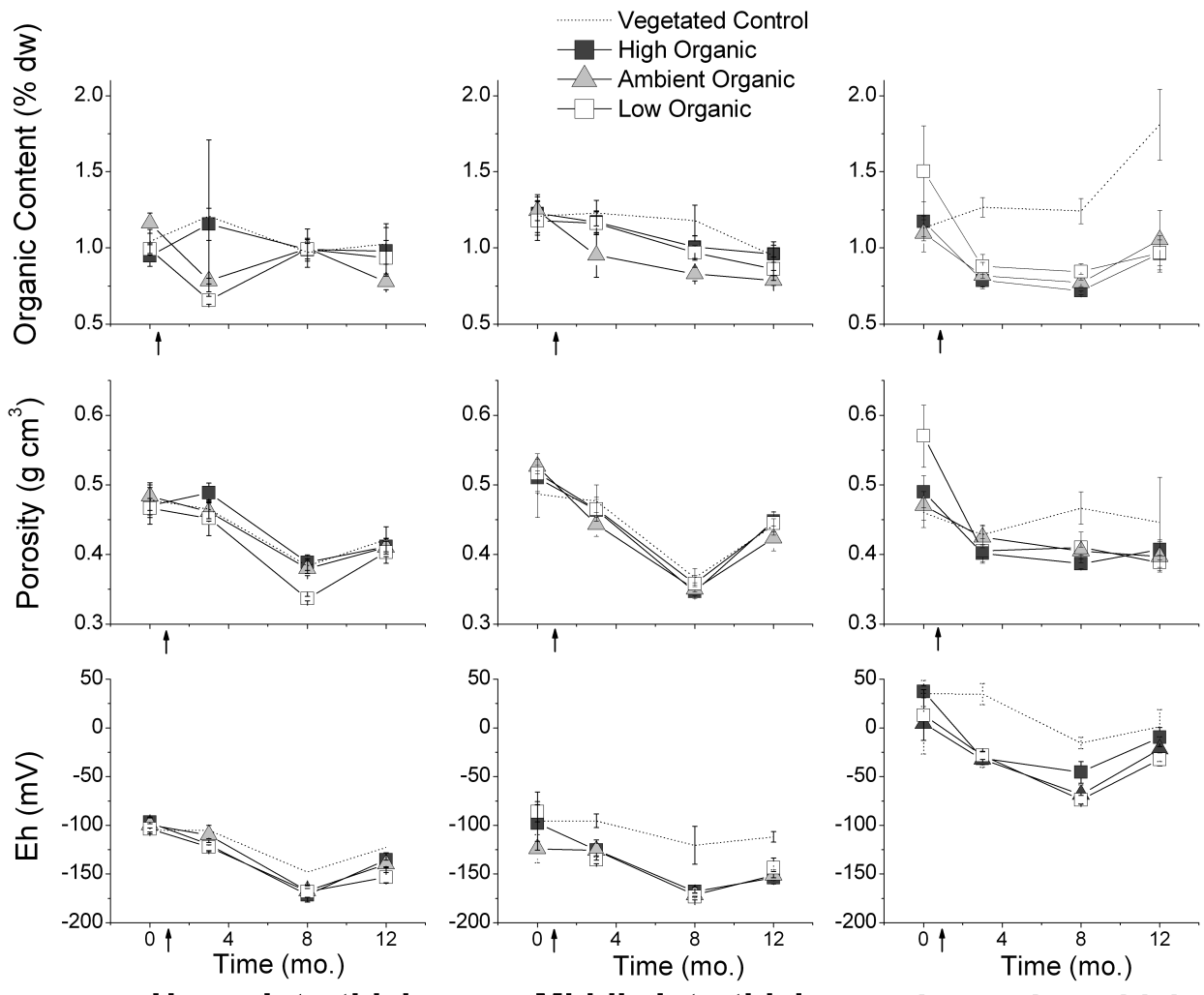

Upper Intertidal

Middle Intertidal

Lower Intertidal

Figure 4.2. Time series of sediment changes during the sediment organic enrichment experiment.

Values are mean $+1 \mathrm{SE}, \mathrm{n}=6$. 

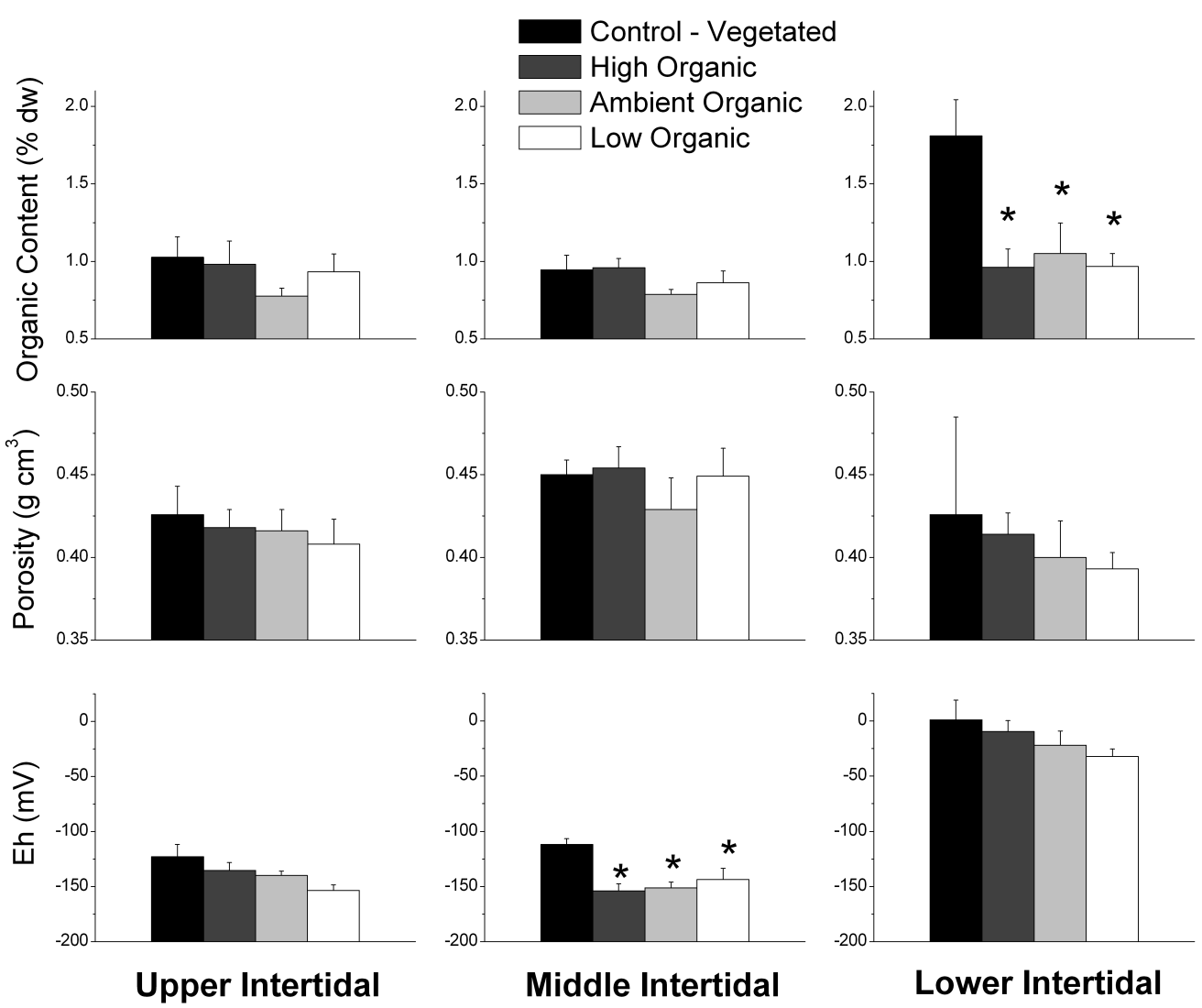

Figure 4.3. Sediment properties at the end of the one year experiment.

Values are mean $+1 \mathrm{SE}, \mathrm{n}=6$. Additional species may have been present at each intertidal site but excluded from this figure because they had a sparse distribution and were not evenly distributed between treatments. 

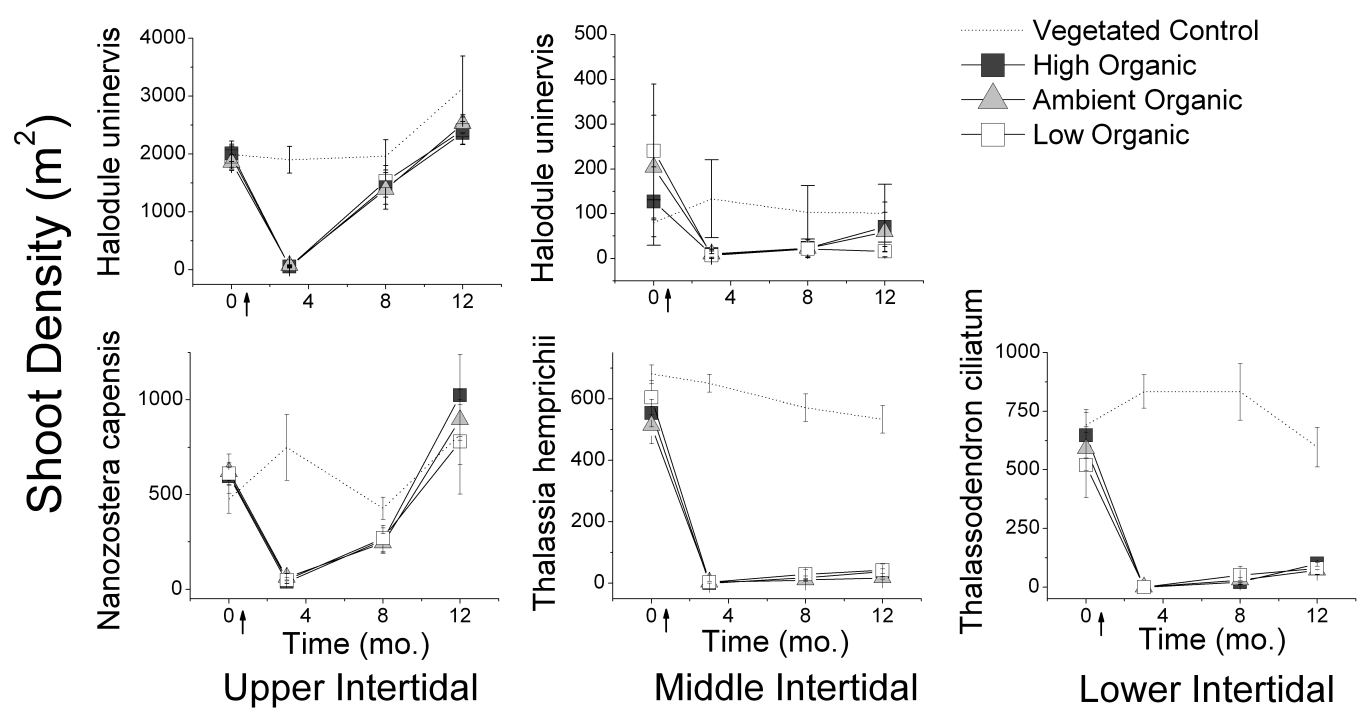

Figure 4.4. Time series of seagrass shoot density changes during the experiment. Values are mean $+1 \mathrm{SE}, \mathrm{n}=6$. Additional species may have been present at each intertidal site but excluded from this figure because they had a sparse distribution and were not evenly distributed between treatments. 


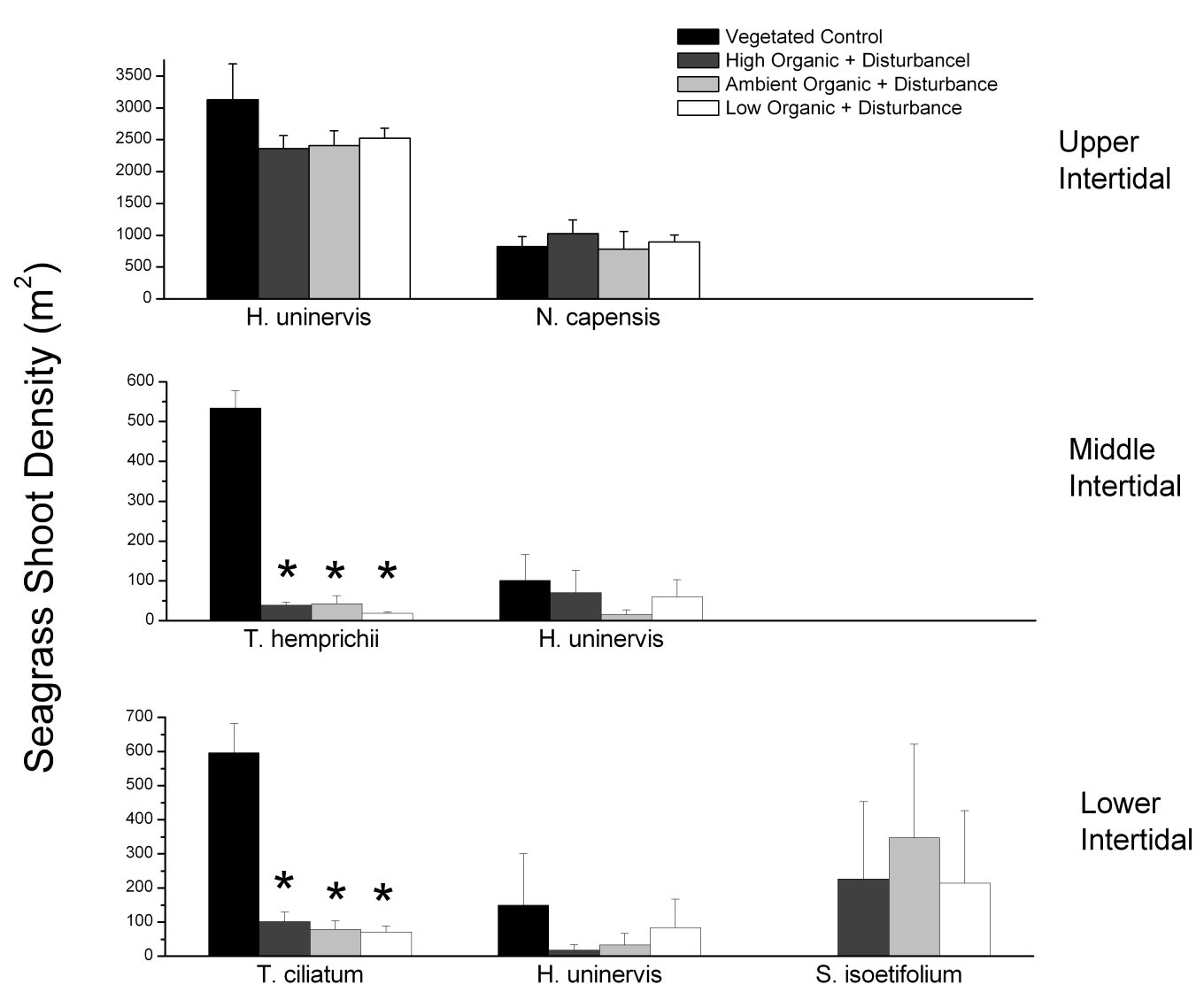

Figure 4.5. Seagrass shoot density at the end of the one year experiment.

Values are mean $+1 \mathrm{SE}, \mathrm{n}=6$. Additional species may have been present at each intertidal site but excluded from this figure because they had a sparse distribution and were not evenly distributed between treatments. 

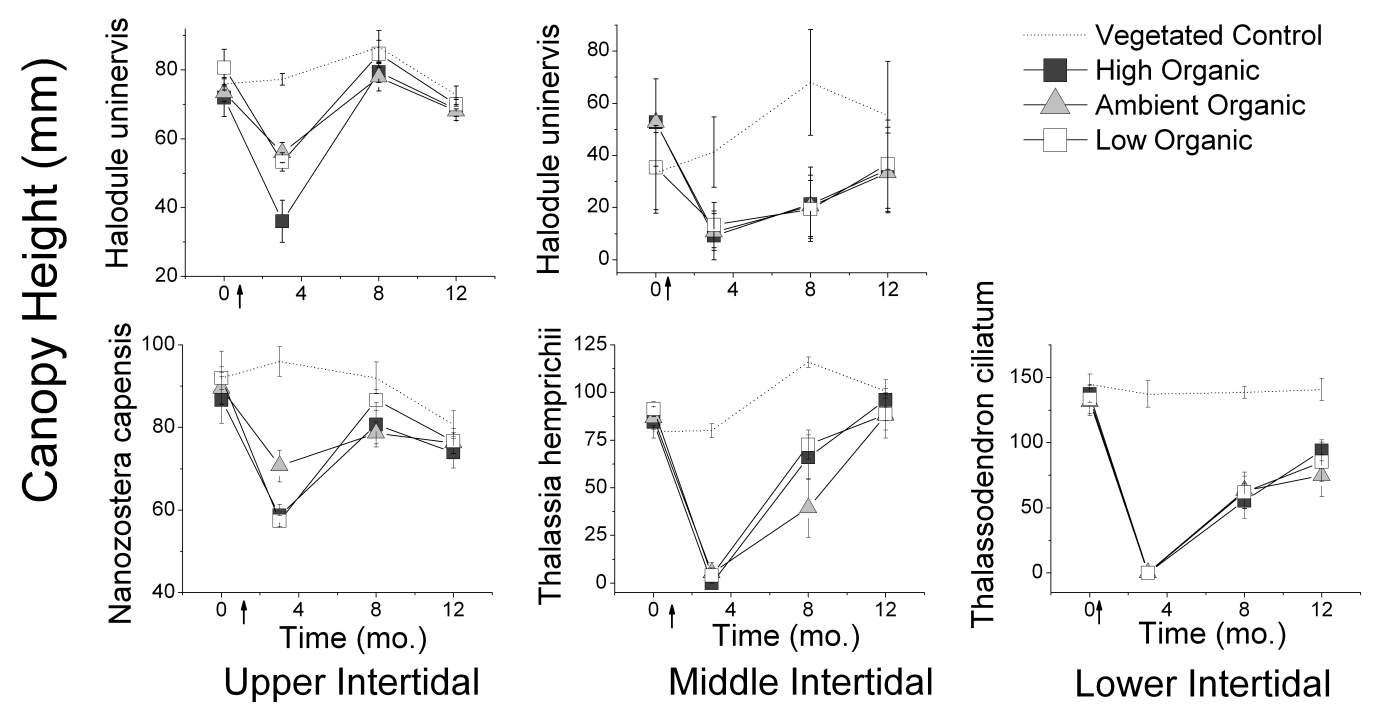

Figure 4.6. Time series of seagrass canopy height ( $80 \%$ of tallest leaf) changes during the experiment.

Values are mean $+1 \mathrm{SE}, \mathrm{n}=6$. Additional species may have been present at each intertidal site but excluded from this figure because they had a sparse distribution and were not evenly distributed between treatments. 


\section{Tables}

\begin{tabular}{|l|c|c|c|}
\hline & Upper & Middle & Lower \\
\hline Water Temperature-Mean $\left({ }^{\circ} \mathrm{C}\right)$ & 26.3 & 24.7 & 26 \\
Water Temperature-Range $\left({ }^{\circ} \mathrm{C}\right)$ & $10.8-46.5$ & $12.9-42.3$ & $15.4-42.4$ \\
Standing Water at MLT $(\mathrm{mm})$ & 25 & 59 & 75 \\
Leaf Exposure (days/month) & 28 & 16 & 7 \\
& & Medium - & \\
Sediment Grain Size & Medium Sand & Coarse sand & Coarse Sand \\
\hline
\end{tabular}

Table 4.1. Physical characteristics of the three intertidal sites.

$\mathrm{N}=6$ for organic content and $\mathrm{n}=4$ for grain size at each site. Sediment grain size is classified by the greatest contribution from a sieve width; medium sand $(0.43-2.0 \mathrm{~mm})$, coarse sand (2.0-4.8 $\mathrm{mm})$. 


\begin{tabular}{|c|c|c|c|c|c|c|c|}
\hline & $\begin{array}{l}\text { Organic } \\
(\% \mathrm{dw})\end{array}$ & $\begin{array}{l}\text { Porosity } \\
\text { (g ml) }\end{array}$ & $\begin{array}{l}\text { Bulk Density } \\
(\mathrm{g} \mathrm{ml})\end{array}$ & $\begin{array}{c}\text { Eh } \\
(\mathrm{mV})\end{array}$ & $\mathrm{Ph}$ & $\begin{array}{l}\text { Total N } \\
(\% d w)\end{array}$ & $\begin{array}{l}\text { Total P } \\
(\% \mathrm{dw})\end{array}$ \\
\hline High Organic & $5.63(.62)$ & $0.52(.02)$ & $1.20(.06)$ & $-143(5)$ & $7.3(.03)$ & $0.49(.02)$ & $0.046(<.01)$ \\
\hline Ambient (Upper Site) & $1.04(.03)$ & $0.46(.01)$ & $1.37(.02)$ & $-105(16)$ & $7.8(.04)$ & $0.13(.02)$ & $0.002(<.01)$ \\
\hline Ambient (Middle Site) & $1.21(.05)$ & $0.43(.01)$ & $1.40(.01)$ & $-95(29)$ & $7.6(.03)$ & $0.73(.13)$ & $0.045(.01)$ \\
\hline Ambient (Lower Site) & $1.25(.09)$ & $0.41(.01)$ & $1.46(.03)$ & $+35(13)$ & $7.6(.05)$ & $0.81(.23)$ & $0.051(<.01)$ \\
\hline Low Organic & $.461(.02)$ & $0.37(.01)$ & $1.48(.04)$ & $+43(6)$ & $7.7(.04)$ & $<0.01(<.01)$ & $0.005(<.01)$ \\
\hline
\end{tabular}

Table 4.2. Sources of sediment for treatment applications.

The High and Low Organic treatments were collected from nearby mangroves and bare sand, respectively. Ambient treatments were collected from the plot following seagrass removal. Values are mean +1 SE. 


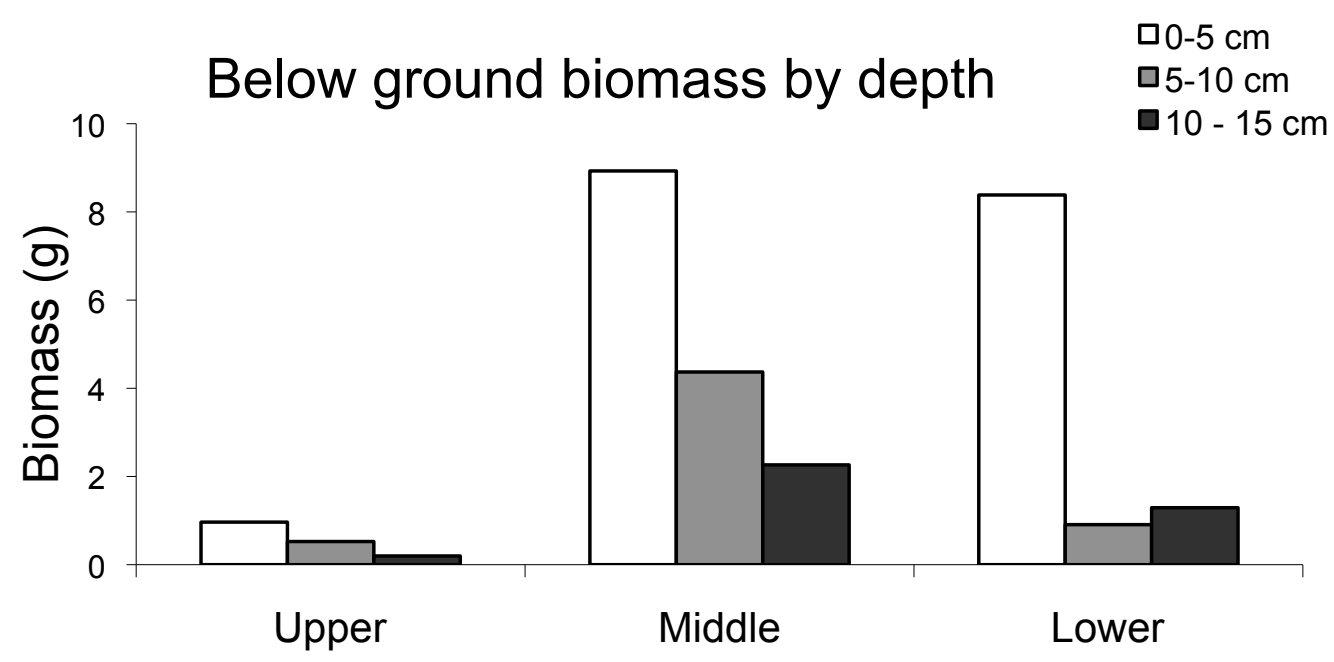

Appendix 4.1. Distribution of seagrass below ground biomass based on sediment depth profiles. $\mathrm{N}=4$ sediment cores for each site, and values are expressed as means. 


\title{
Chapter Five: Spatial and temporal dynamics of gap creation within seagrass meadows across an Indo-Pacific intertidal landscape
}

\begin{abstract}
Openings created within a vegetated environment by disturbance events, also known as gaps, can influence habitat heterogeneity and associated ecological processes. This study investigated spatial and temporal dynamics of gaps within intertidal seagrass habitats. High-resolution satellite imagery with a pixel resolution of $0.60 \mathrm{~m}$ and a spatial extent of $106 \mathrm{~km}^{2}$ was used to create seagrass distribution maps of Inhaca Island, Mozambique. Seagrass covered $52 \%$ of the intertidal area, with an overall classification mapping accuracy (Kappa statistic) of 0.85 . Thirty sampling grid cells of $50 \mathrm{~m}$ x $50 \mathrm{~m}$ were selected within seagrass meadows from each of the three tidal zones (upper, middle and lower intertidal) for a total sampling area of $75,000 \mathrm{~m}^{2}$. The number and size of every bare gap that was less than $250 \mathrm{~m}^{2}$ within each grid cell was measured in the 2006 and 2008 images. Gaps contributed to a relatively small area in each grid for both 2006 $(0.17 \%$ gap area $)$ and 2008 (0.12\% gap area), with a maximum recorded gap areal extent of $8.4 \%$. The observed difference in total gap area over two years was negligible $(0.05 \%$ decrease for the entire landscape) and it may be perceived that gaps are not changing. However, a substantial amount of change in the number and size of gaps was identified between 2006-2008. Of the original 637 gaps identified, $14 \%$ expanded, $14 \%$ remained the same size, $44 \%$ contracted, and $27 \%$ disappeared. A total of 137 new gaps were
\end{abstract}


created in 2008 that were not present in 2006. Small-sized gaps $\left(<1 \mathrm{~m}^{2}\right)$ could persist for years, and in some cases even expand. Gap contraction and closure rates in areas dominated by fast-growing species (e.g. Halodule uninervis) were slower than expected, where $43 \%$ of gaps expanded or stayed static in the upper intertidal. This contradicts predictions based on seagrass growth rates as well as results from previous studies. The persistence of these small gaps is attributed to a combination of continuous disturbance regimes (e.g. bioturbation and hydrodynamic activity) that is especially prevalent in these upper intertidal zones. The observed pattern of higher disturbance intensity in the upper intertidal zone collaborates with patterns found during an intensive multi-week field survey covering the spatial area (Chapter 2). This suggests that high-resolution satellite imagery, with some limitations, may be a useful and practical tool to assess general gap dynamics for intertidal system. Data here illustrates that intertidal seagrass meadows are highly dynamic. Small-sized gaps created by disturbances $\left(<10 \mathrm{~m}^{2}\right)$ can persist for up to two years, in some cases even expand, and therefore should be included in studies of spatial patterns and landscape dynamics.

\section{Introduction}

The application of landscape ecology principles to seagrass ecosystems is a relatively recent phenomena (Bell et al. 2006), and a growing body of work is being directed at understanding the relationship between spatial pattern and ecological processes. One such topic is related to the spatial characteristics and changes in gaps, with gaps being defined 
as openings created within a vegetated environment by disturbance events (Runkle 1982). This seagrass gap concept is analogous to that of light gaps created by tree falls in forests (Oldeman 1978), lightning strikes in mangroves (Sherman et al. 2000), or badger mounds in grasslands (Platt 1975). When a gap is created in these communities, resources such as light and space are made available for new species recruitment.

Gaps are created in seagrass habitats by a range physical and biological disturbance agents (Short and Wyllie-Echeverria 1996). Most studies on gap change in seagrass habitats have focused on the distribution and recovery of anthropogenic driven events such as boat prop scaring (Sargent et al. 1995, Dawes et al. 1997, Hammerstrom et al. 2007) and vessel groundings (Fonseca et al. 2004). Naturally occurring disturbances that create gaps include bioturbation (Townsend and Fonseca 1998), storm events (Davis et al. 2004), and "blowouts" which are bare areas with eroding edges that often migrate across the landscape (Patriquin 1975).

Research on gap dynamics for seagrasses have focused on the immediate recovery phase following disturbance, using approaches such as conducting experiments that replicate gap creation (Rasheed 1999), or monitoring existing gaps (Olesen et al. 2004). To our knowledge, only Bell et al. (1999) have tried explicitly to quantify natural gap dynamics (e.g. formation, expansion, extinction) within seagrass meadows. Their two-year study monitored seagrass at fine scales $\left(1 \mathrm{~m}\right.$ intervals) across a large area $\left(48,800 \mathrm{~m}^{2}\right)$ in Tampa Bay, Florida and found that gap dynamics were related to a combination of disturbance 
regimes such winter sedimentation events, and sediment stability based on particle size. Despite a conclusion arguing for fine-scale resolution of landscape-scale patterns to accurately describe and understand seagrass dynamics, the Bell et al. study restricted their study on gaps to areas greater than $10 \mathrm{~m}^{2}$ because of an assumption that gaps smaller than $10 \mathrm{~m}^{2}$ were unimportant contributors to overall gap dynamics at the landscape scale.

There is a paucity of research on smaller-scale disturbances (e.g. $<10 \mathrm{~m}^{2}$ ), despite their potential influence on landscape processes. For example, Duarte et al. (1997) estimated that an entire tropical mixed-species meadow in the Philippines could be reworked by bioturbation disturbances every two years, based on observations of shrimp density and burrowing activity. No study has attempted to quantify small-scale gap changes in a seagrass landscape. Small-scale gaps are created by a variety of disturbances, such as hydrodynamic activity and bioturbation, and these processes are especially prevalent in some intertidal zones. For example, extensive field surveys within intertidal seagrass meadows in Mozambique identified the most common gap size occurring as being less than $1 \mathrm{~m}^{2}$ (Chapter 2). More information is needed to understand how small-scale and more frequent disturbances can affect landscape structure and function.

Monitoring gap dynamics often requires extensive field work over several years and may be beyond the resources available for many projects. The increasing use of commercial high- resolution satellite imagery $\left(<1 \mathrm{~m}^{2}\right.$ pixel resolution) now allows investigators to delineate seagrass distribution across a greater spatial extent, and is regularly used to 
complement existing field-based methods (Roelfsema et al. 2009). These images are useful in identifying large-scale changes in seagrass distribution such as calculating the percent change in seagrass distribution over time or determining if a give patch is expanding or contracting (Dekker et al. 2005, Gullstrom et al. 2006). High resolution satellite imagery has not yet been used to specifically investigate seagrass gap dynamics.

\section{Objectives}

This study used high-resolution satellite imagery $(0.6 \times 0.6 \mathrm{~m})$ to determine gap dynamics within seagrass meadows across an intertidal gradient. Specific objectives were to (1) identify seagrass distribution across an Indo-Pacific intertidal landscape using remote sensing and extensive field surveys, (2) quantify the size and number of gaps within seagrass meadows along a tidal gradient, and (3) describe how the size and number of gaps change over a two-year period. This is the first study to quantify largescale patterns of naturally occurring small-scale processes $\left(<1 \mathrm{~m}^{2}\right)$ in seagrass ecosystems.

\section{Methodology}

\section{Study Site}

Inhaca Island is located off the east coast of southern Mozambique between latitudes $25^{\circ} 58^{\prime}$ and $26^{\circ} 05^{\prime} \mathrm{S}$ and longitudes $32^{\circ} 55^{\prime}$ and $33^{\circ} 00^{\prime} \mathrm{E}$, and has a shoreline of ca. $60 \mathrm{~km}^{2}$ 
(Figure 5.1). Tides are semi-diurnal and vary from 0.26 and $3.83 \mathrm{~m}$, with average amplitude for spring and neap tides of $3.2 \mathrm{~m}$ and $1.5 \mathrm{~m}$, respectively. Seagrass covers approximately $50 \%$ of the Inhaca intertidal zone, can be found in areas ranging from muddy to rocky habitats, and are highly diverse with eight species in three families (Bandeira 2002). Seagrass is absent from the eastern side due to the steep slope of the shoreline and exposure to high-energy waves and winds from the West Indian Ocean. The northern and southern bays are well protected and contain extensive continuous seagrass meadows that are interrupted occasionally by channels between sand banks. The western side of Inhaca faces Maputo Bay and is characterized by expansive intertidal sand flats with a narrow zone of seagrass that is followed by a sharp decrease in depth. Inhaca Island also has intact coral reef patches, mangrove creeks, and relatively minimal human impact due to low population densities.

\section{Seagrass Distribution}

High-resolution QuickBird (Digital Globe) satellite images were acquired for a spatial extent of $106 \mathrm{~km}^{2}$ over Inahca Island on July 11, 2006 and June 25, 2008. The images were pan-sharpened, which allows for the integration of spatial data within panchromatic images $(0.6 \mathrm{~m}$, spectral range $450-900 \mathrm{~nm})$ with spectral data of multispectral imagery (2.44 m, spectral ranges: 450-520, 520-600, 630-690, 790-900 nm). The resulting natural color imagery has a spatial resolution of 0.6 meters per pixel. This type of satellite imagery was selected because it provides an extremely high degree of spatial detail and 
because the focus of the study is on spatial patterns rather than spectral-related data such as vegetation indices (e.g. NDVI). The wavelengths in these images are represented in the three visible bands (blue, green, red) and are able to penetrate shallow water. Data were geometrically and radiometrically corrected in coordinate system UTM-36 with datum NAD83. Imagery was acquired during low tide and was cloud free. The time windows of image acquirement correspond with the subtropical winter in southern Mozambique. The difference of one month in image acquisition does not correspond with significant changes in seagrass distribution or growth (Chapter 3).

Images were orthorectified by the vendor (geoVAR, LLC) and the 2008 image was georeferenced to the 2006 image with a Relative Geospatial Registration Accuracy of 2 m. An Area of Interest (AOI) mask was created to focus on the intertidal zone and to exclude terrestrial habitats, deep water and large sand bars. No water depth correction was required because our AOI was restricted to the intertidal zone which was either exposed during the time of imagery acquisition or in very shallow clear water.

A map depicting seagrass cover was created for the 2006 image using a supervised classification with 207 independent signatures and a maximum likelihood classifier in ERDAS Imagine software. A supervised classification was used because good knowledge of the area was available beforehand from extensive field surveys. Two land cover types were created: seagrass patches and bare gaps. Differentiating between individual seagrass 
species accurately was not possible due to both the high co-existence of species in the intertidal zone (Chapter 2) and spectral similarities between species.

To determine the thematic accuracy of the classification, 405 training points were obtained from the 2006 field survey that occurred within one month of the 2006 image acquisition (Chapter 2). An error matrix was used to generate several accuracy indices: User's measures the confidence that a classified pixel accurately represents the actual class, Producer's shows what percentage of the class was correctly classified, and Overall Accuracy is the total percentage of correctly classified benthic classes.

\section{Gap Distribution and Dynamics}

To asses the distribution and dynamics of gaps within the seagrass meadows, a fishnet grid of $50 \mathrm{~m}$ x $50 \mathrm{~m}$ cells was applied across the original un-classified images (2006 and 2008) using ArcGIS 9.3 (Figure 5.2). Each cell was assigned an intertidal zone that was based on a combination of extensive field measurements and visual interpretation. These zones represent a gradient of standing water $(\mathrm{cm})$ at mean low tide and exposure frequency (days/month): upper intertidal $(0 \mathrm{~cm}$, exposed ca. 28 days $)$, middle intertidal (1-10 cm, exposed ca. 16 days), and lower intertidal (10-30 cm, exposed ca. 7 days). Grid cells were excluded if they were located along the patch edge, if human impact was present (walking paths, boats), or if the image quality was compromised due to the rising tide in some areas that prevented comparison between images. 
Thirty grid cells were selected from each of the three tidal locations using a stratified random design that ensured even geographic distribution around the island $(\mathrm{NW}, \mathrm{NE}$, $\mathrm{SW}, \mathrm{SE}$ ), for a total area sampled of $75,000 \mathrm{~m}^{2}$ within the entire seagrass intertidal zone. Each gap within the 30 identified sample cells was visually counted and the area was measured using GIS tools. The definition of a gap used in this approach was any which area of unvegetated benthos surrounded by contiguous seagrass. A pixel was no longer considered part of the gap if there was ca. $25 \%$ recolonization based on visual estimation and field surveys. Each gap was classified according to three size classes: $<1 \mathrm{~m}^{2}, 1-25$ $\mathrm{m}^{2}$, and $25-250 \mathrm{~m}^{2}$.

Gap dynamics were assessed by: 1) the direction of change for each identified gap between 2006 and 2008, and 2) whether a 2006 gap expanded, did not change, contracted or disappeared over the 2-year period. Any gaps present in 2008, but not in 2006, were considered a newly created gap. Larger scale gaps $\left(>250 \mathrm{~m}^{2}\right)$ were present but infrequent and patchy in distribution, thus preventing an estimation of gap extent over the size of our sample cells. Because large-sized gaps can also contribute to landscape heterogeneity, these were investigated using a separately by randomly selecting 5 gaps (greater than 250 $\mathrm{m}^{2}$ ) from each of the intertidal zones. Change in percent area of these large gaps was calculated by digitizing the gaps by hand in both the 2006 and 2008 images. 


\section{Results}

\section{Seagrass distribution}

Seagrass was found in $51.85 \%$ of the intertidal zone, which represents ca. $21.14 \mathrm{~km}^{2}$

(Figure 5.3, Table 5.1), and is similar to the 50\% value reported in previous distribution studies on Inhaca Island (Bandeira 2002). Seagrass distribution was most continuous in the sheltered northern bay, where it was largely composed of mixed meadows dominated by Thalassia hemprichii and Halodule uninervis. Seagrass distribution was more patchy and fragmented along the end points of the intertidal gradient; the upper intertidal dominated by Halodule uninervis and the subtidal fringe dominated by Thalassodenron ciliatum. The overall classification accuracy (Kappa statistic) of the image was 0.85 . The overall accuracy was higher for seagrass $(91.7 \%)$ compared to bare areas $(73.4 \%)$ due to the misclassification of darker muddy sediments as seagrasses. The producer and user accuracy for the seagrass category was 93.62 and $97.55 \%$, respectively. The producer and user accuracy for the unvegetated category was 90.79 and $78.41 \%$, respectively.

\section{Gap distribution}

Gaps within continuous seagrass meadows were common across the landscape and were present in all our sampling grid cells (Table 5.2). Overall, gaps typically represented only a small area in each grid for both 2006 (0.17\% gap area) and 2008 (0.12\% gap area). The majority of sample cells contained less than $1 \%$ of bare gap area, although some cells had more, with the maximum recorded gap area of 8.4\% (Figure 5.4). Gap extent 
decreased with depth, with the upper intertidal containing the greatest percentage of gap area (Figure 5.5). Rates of change for small to mid-sized gaps $\left(<250 \mathrm{~m}^{2}\right)$ appear to be greater in the upper intertidal (loss of $78 \mathrm{~m}^{2}$ ) and lower in the lower intertidal (gain of $8 \mathrm{~m}^{2}$ )(Table 5.2). These values may underestimate total gap coverage across the intertidal zone because large sized gaps $\left(<250 \mathrm{~m}^{2}\right)$ were excluded due to their infrequency and patchy distribution, and they exceeded the size of our sample grid cell.

A closer examination of changes over a two year period shows that gaps can be highly dynamic (Figure 5.6). Smaller disturbances $\left(<1 \mathrm{~m}^{2}\right)$ were observed more frequently overall compared to larger size disturbances. In the 2006 image, 464 individual gaps less than $1 \mathrm{~m} 2$ were counted, compared to 134 and 20 of gap sizes $1-25 \mathrm{~m}^{2}$ and $25-250 \mathrm{~m}^{2}$, respectively. Of the original 637 gaps identified within 30 sample grids cells, $14 \%$ expanded, $14 \%$ remained the same size, $44 \%$ contracted, and $27 \%$ disappeared (Table 5.3). There were 137 newly created gaps in 2008 that were not present in 2006, which is $22 \%$ of the total number of gaps it started with. Large sized gaps $\left(>250 \mathrm{~m}^{2}\right)$ often overlapped between grid cells $(50 \mathrm{~m}$ x $50 \mathrm{~m})$. Therefore they were measured separately and not found in any of our sample cells. Variability in these large sized gaps was wide, as evidenced by the very different median and mean values, with values ranging from $327 \mathrm{~m}^{2}$ to $28,746 \mathrm{~m}^{2}$ (Table 5.4). In general, larger gaps were more common along the edges of seagrass patches. 


\section{Discussion}

This study shows that gaps within intertidal seagrass meadows are highly dynamic, and that gaps can influence habitat heterogeneity at local and landscape scales. The continuous creation of gaps by disturbances, and their subsequent expansion, contraction and closure, results in a constant reworking of sediment and vegetation. These processes can easily be overlooked if one is only assessing changes in total percent seagrass area over time - which is the most common metric used to understand seagrass dynamics. For example, a snap shot of the two sampling dates reveals a negligible difference $(0.05 \%)$ in total gap area between 2006 and 2008, which may be interpreted that gaps are not changing. On closer examination, however, there was a substantial amount of change in the number and size of gaps between the two years. This clearly demonstrates that the presence and size of small-scale disturbances are constantly evolving.

Small-sized gaps in this location $\left(<1 \mathrm{~m}^{2}\right)$ can persist for nearly two years, and in some cases even expand, which contradicts results from other studies. For example, Bell et al. (1999) limited their definition of gaps to those greater than $10 \mathrm{~m}^{2}$ because smaller gaps were observed to close rapidly and thus their impact on habitat heterogeneity was limited. They also found that no gaps less than $15 \mathrm{~m}^{2}$ persisted more than 1 year. In contrast, a sizable amount of these smaller gaps did persist in the present study.

Based on the dominance of fast-growing species in the upper intertidal, gaps in this particular tidal zone would be expected to contract and close quickly due to high plant 
growth and expansion rates. Bell et. al (1999) attributed much of their observed gap closure to the fast turnover of Halodule wrightii, a cogeneric species to the Halodule uninervis found in on Inhaca Island. Further support for rapid gap closure can be found in disturbance experiments that found full seagrass recovery within two years using smallscale plots less than $<1 \mathrm{~m}^{2}$ and species that were the same, or similar, to our upper intertidal species (Chapter 3) (Rollon et al. 1998, Rasheed 2004). Surprisingly, the predicted high gap closure rates was not observed. Only $39 \%$ of the 2006 gaps in the upper intertidal exhibited complete closure, and $18 \%$ contracted. Nearly half of the gaps stayed the same or expand in size over the two year time frame; $8 \%$ increased in size and $34 \%$ remained the same size after 2 years.

It is difficult to identify exactly why the gaps observed in this study were more likely to persist compared to those studies that observed closure within the temporal frame used here. Data collected during disturbance surveys discussed in Chapter 2 suggest that both the intertidal environment and the agents of disturbance common to this environment, may have enhanced the persistence of gaps observed. Disturbance activity and gap frequency varied along a depth gradient, where more gaps were found in the upper intertidal compared to the middle and lower intertidal. Several factors may contribute to the pattern of decreasing gaps with depth; the upper intertidal has higher disturbance intensity due to bioturbator densities, more direct exposure to wind and wave processes, and smaller pioneer plant species (e.g. H. uninervis) that are more vulnerable to disturbances (Chapter 2). In contrast, reduced gap presence in the lower intertidal may be 
due to fewer bioturbators, and the larger-sized plant species (e.g. T. ciliatum) are more resistance to some disturbances such as sedimentation (Chapter 3). Some bioturbation activity can continue in one location for up to a year and this would hinder recolonzation and closure of gaps. Therefore, there may have been less gap closure because of a presence of continuous disturbances (bioturbation activity) rather than one-time events (e.g., wind-driven sedimentation).

Small-sized gaps behaved differently than large sized gaps. Gap contraction was considerably greater for large sized gaps $\left(>250 \mathrm{~m}^{2}\right)$ compared to small sized gaps $(<250$ $\mathrm{m}^{2}$ ); larger-sized gaps exhibited a $35 \%$ decrease in areal coverage, smaller-sized gaps exhibited a $0.05 \%$ decrease. This high contraction rate in large sized gaps is likely a result of increased seagrass recolonization via rhizome elongation into the gap from the extended edge area (Kendrick et al. 1999). Other studies have also found contraction and closure to be more common than expansion in larger sized gaps (Bell et al. 1999). However, two large-sized gaps did expand, which can occur when there is increased sediment resuspension and erosion following strong hydrodynamic activity (Whitfield et al. 2002). Another factor influencing changes in gap areal coverage is the frequency of the associated disturbance events that led to the gap creation. Disturbances that produce large gaps, such as extreme storm events, are typically infrequent and more than two years of data would be required to capture the dynamics of these larger sized gaps. 
The fact that the high rates of gap persistence observed in this study did not align with experimental work predicting gap closure after 2 years for sites with faster growing species (upper and middle intertidal) highlights some of the limitations in using remote sensing to identify gap processes. Most important is that satellite data do not distinguish among factors that affect gap closure and seagrass recovery rates. For example, most satellite imagery alone can not differentiate specific species based on similarities in spectral signatures (Fyfe 2003), although hyperspectral imagery may be assist in this regard. Information on species composition can provide some insight into recovery rates based on species-specific growth traits. However, it may not always be a useful predictor as indicated by the slow recovery of small-sized gaps in areas dominated by fast growing species. Other factors relating to the three-dimensionality of the gap can be important in determining the rate and trajectory of recovery, such as the depth of sediment burial or erosion in the gap, or sediment type (Kenworthy et al. 2002, Kirsch et al. 2002, Cabaco et al. 2008))Chapter 3). In addition, a satellite image can not capture the status of the disturbance agent, such as determining if bioturbation is still active. Other external factors that may affect the persistence of gaps include localized grazing pressure (Chapter 3) or selective herbivory as seen when turtles return to the same patch (Williams 1988).

The patterns of higher disturbance intensity identified in this study were also found during a more intensive multi-week field survey (Chapter 2), suggesting that highresolution satellite imagery may be a useful and practical tool to assess general gap dynamics for intertidal systems. However, high-resolution imagery still has strong spatial 
resolution constraints. Our pixel resolution was $0.6 \mathrm{~m} \times 0.6 \mathrm{~m}$, allowing us to analyze gap dynamics at an unprecedented level of detail using remote sensing. However, the presence and changes in very small gaps were not likely captured $\left(<0.5 \mathrm{~m}^{2}\right)$. The merging of pixel content often leads to blurred edges, which can make it difficult to identify the perimeter of a gap. This can lead to an underestimation of these very small gaps because pixels were only labelled a gap if there was high certainty. Since these particular gaps have been shown to be the dominant size category of disturbances in some intertidal zones (Chapter 2), excluding these very small gaps from our analysis leaves out a very important component of gap dynamics. Aerial imagery may provide higher resolution that can be used to monitor changes in gaps less than $1 \mathrm{~m}^{2}$, but the acquisition of these images can be expensive and logistically difficult in many parts of the world. For now, field-based monitoring is necessary to accurately capture the presence and dynamics of small-scale disturbances.

One limitation in our study is the exclusion of margin gaps, where seagrass growth and expansion patterns along patch edges envelope an unvegetated area and create a gap. This type of gap has been shown to affect overall landscape heterogeneity (Bell et al. 1999). Margin gaps in this study were particularly common along the seagrass edge in the deeper zones where other disturbances such as channel currents are more chronic. Inclusion of margin gaps along these edges would have increased the relative contribution of gaps to the seagrass landscape. Margin gaps also tend to behave differently than interior gaps located within the seagrass patch. For example, interior- 
produced gaps are created primarily by sedimentation events in the winter, whereas margin gaps are most commonly created by seagrass expansion during the summer (Bell et al. 1999). Although our study did not examine images acquired in different seasons, our two-year period between imagery dates does integrate and reflect those seasonal affects.

This study documents that intertidal seagrass meadows are highly dynamic. Small-sized gaps $\left(<10 \mathrm{~m}^{2}\right)$ can persist for two years, and in some cases even expand, and therefore should be included in studies of spatial patterns and landscape dynamics. Small-sized gaps have historically been neglected in seagrass disturbance research, despite evidence that these processes can impact a range of seagrass features, from biological aspects such as biodiversity (Duarte et al. 1997) to physical aspects such as hydrodynamic activity (Maltese et al. 2007). Studies on these gap dynamics are ideal for linking landscape-scale processes with plant-scale recovery patterns and can eventually be used in creating models of seagrass recovery. Future research efforts are needed to determine the role of small-scale disturbances in other intertidal and subtidal systems, and to further explore how spatial patterns of gaps affect other ecological processes such as habitat use by fauna. 


\section{References}

Bandeira, S., 2002. Diversity and distribution of seagrasses around Inhaca Island, southern Mozambique. South African Journal of Botany 68: 191-198.

Bell, S. S., B. D. Robbins, and S. L. Jensen. 1999. Gap dynamics in a seagrass landscape. Ecosystems 2: 493-504.

Bell, S. S., M. S. Fonseca, and N. B. Stafford. 2006. Seagrass ecology: New contributions from a landscape perspective, pp. 625-645 in Seagrasses: Biology, Ecology and Conservation, edited by A. W. D. Larkum, R. J. Orth and C. M. Duarte. Springer.

Cabaco, S., R. Santos, and C. M. Duarte. 2008. The impact of sediment burial and erosion on seagrasses: A review. Estuarine Coastal Shelf Science 79: 354-366.

Davis, S. E., J. E. Cable, D. L. Childers, C. Coronado-Molina, J. W. Day, C. D. Hittle, C. J. Madden, E. Reyes, D. Rudnick, and F. Sklar. 2004. Importance of storm events in controlling ecosystem structure and function in a Florida gulf coast estuary. Journal of Coastal Research 20: 1198-1208.

Dawes, C. J., J. Andorfer, C. Rose, C. Uranowski, and N. Ehringer. 1997. Regrowth of the seagrass Thalassia testudinum into propeller scars. Aquatic Botany 59: 139155.

Dekker, A. G., V. E. Brando, and J. M. Anstee. 2005. Retrospective seagrass change detection in a shallow coastal tidal Australian lake. Remote Sensing of Environment 97: 415-433.

Duarte, C. M., J. Terrados, N. S. R. Agawin, M. D. Fortes, S. Bach, and W. J. Kenworthy. 1997. Response of a mixed Philippine seagrass meadow to experimental burial. Marine Ecology Progress Series 147: 285-294.

Fonseca, M. S., P. E. Whitfield, W. J. Kenworthy, D. R. Colby, and B. E. Julius. 2004. Use of two spatially explicit models to determine the effect of injury geometry on natural resource recovery. Aquatic Conservation 14: 281-298.

Fyfe, S. K., 2003. Spatial and temporal variation in spectral reflectance: Are seagrass species spectrally distinct? Limnology and Oceanography 48: 464-479.

Gullstrom, M., B. Lunden, M. Bodin, J. Kangwe, M. C. Ohman, M. S. P. Mtolera, and M. Bjork. 2006. Assessment of changes in the seagrass-dominated submerged vegetation of tropical Chwaka Bay (Zanzibar) using satellite remote sensing. Estuarine Coastal Shelf Science 67: 399-408.

Hammerstrom, K. K., W. J. Kenworthy, P. E. Whitfield, and M. F. Merell. 2007. Response and recovery dynamics of seagrasses Thalassia testudinum and Syringodium filiforme and macroalgae in experimental motor vessel disturbances. Marine Ecology Progress Series 345: 83-92.

Kendrick, G. A., J. Eckersley, and D. I. Walker. 1999. Landscape-scale changes in seagrass distribution over time: a case study from Success Bank, Western Australia. Aquatic Botany 65: 293-309.

Kenworthy, W. J., M. S. Fonseca, P. E. Whitfield, and K. K. Hammerstrom. 2002. Analysis of seagrass recovery in experimental excavations and propeller-scar 
disturbances in the Florida Keys National Marine Sanctuary. Journal of Coastal Research 75-85.

Kirsch, K. D., J. F. Valentine, and K. L. Heck. 2002. Parrotfish grazing on turtlegrass

Thalassia testudinum: evidence for the importance of seagrass consumption in food web dynamics of the Florida Keys National Marine Sanctuary. Marine Ecology Progress Series 227: 71-85.

Maltese, A., E. Cox, A. M. Folkard, G. Ciraolo, G. La Loggia, and G. Lombardo. 2007. Laboratory measurements of flow and turbulence in discontinuous distributions of ligulate seagrass. Journal of Hydraulic Engineering 133: 750-760.

Oldeman, R. A. A., 1978. Architecture and energy exchange of dicotyledonous trees in the forest. Tropical Trees as Living Systems. Cambridge University Press, Cambridge.

Olesen, B., N. Marba, C. M. Duarte, R. S. Savela, and M. D. Fortes. 2004. Recolonization dynamics in a mixed seagrass meadow: The role of clonal versus sexual processes. Estuaries 27: 770-780.

Patriquin, D. G., 1975. "Migration" of blowouts in seagrass beds at Barbados and Carriacou, West Indies, and its ecological and geological implications. Aquatic Botany 163-189.

Platt, W. J., 1975. The colonization and formation of equilibrium plant species associations on badger disturbances in a tall-grass prairie. Ecological Monographs 285-305.

Rasheed, M. A., 1999. Recovery of experimentally created gaps within a tropical Zostera capricorni (Aschers.) seagrass meadow, Queensland Australia. Journal of Experimental Marine Biology and Ecology 235: 183-200.

Rasheed, M. A., 2004. Recovery and succession in a multi-species tropical seagrass meadow following experimental disturbance: the role of sexual and asexual reproduction. Journal of Experimental Marine Biology and Ecology 310: 13-45.

Roelfsema, C. M., S. R. Phinn, N. Udy, and P. Maxwell. 2009. An Integrated Field and Remote Sensing Approach for Mapping Seagrass Cover, Moreton Bay, Australia. Journal of Spatial Science 54: 45-62.

Rollon, R. N., E. D. D. Van Steveninck, W. Van Vierssen, and M. D. Fortes. 1998. Contrasting recolonization strategies in multi-species seagrass meadows. Marine Pollution Bulletin 37: 450-459.

Runkle, J. R., 1982. Patterns of disturbance in some old-growth mesic forests of eastern North America. Ecology 1533-1546.

Sargent, F. J., T. J. Leary, D. W. Crewz, and C. R. Kruer. 1995. Scarring of Florida's Seagrasses: Assessment and Management. Florida Marine Research Institute Technical Report TR-1 .

Sherman, R. E., T. J. Fahey, and J. J. Battles. 2000. Small-scale disturbance and regeneration dynamics in a neotropical mangrove forest. Journal of Ecology 88: $165-178$.

Short, F. T. and S. Wyllie-Echeverria. 1996. Natural and human-induced disturbance of seagrasses. Environmental Conservation 23: 17-27. 
Townsend, E. C. and M. S. Fonseca. 1998. Bioturbation as a potential mechanism influencing spatial heterogeneity of North Carolina seagrass beds. Marine Ecology Progress Series 169: 123-132.

Whitfield, P. E., J. W. Kenworthy, K. K. Hammerstrom, and M. S. Fonseca. 2002. The role of a hurricane in the expansion of disturbances initiated by motor vessels on seagrass banks. Journal of Coastal Research 86-99 .

Williams, S. L., 1988. Thalassia testudinum productivity and grazing by green turtles in a highly disturbed seagrass bed. Marine Biology 98: 447-455. 
Figures

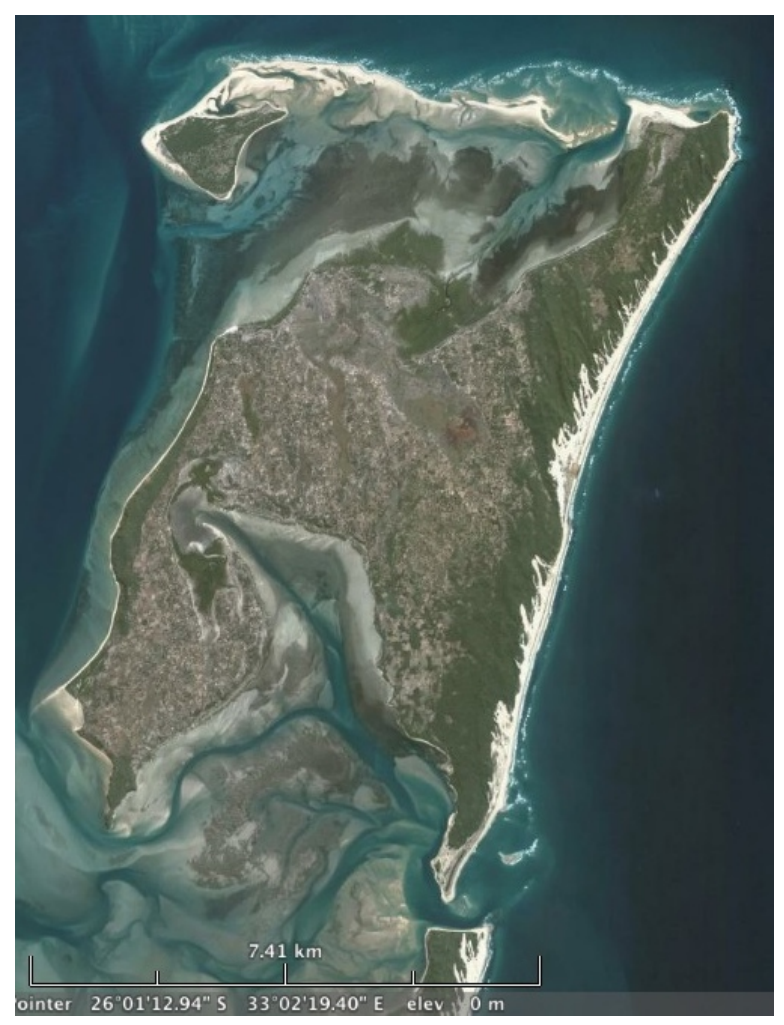

Figure 5.1. Map of Inhaca Island 

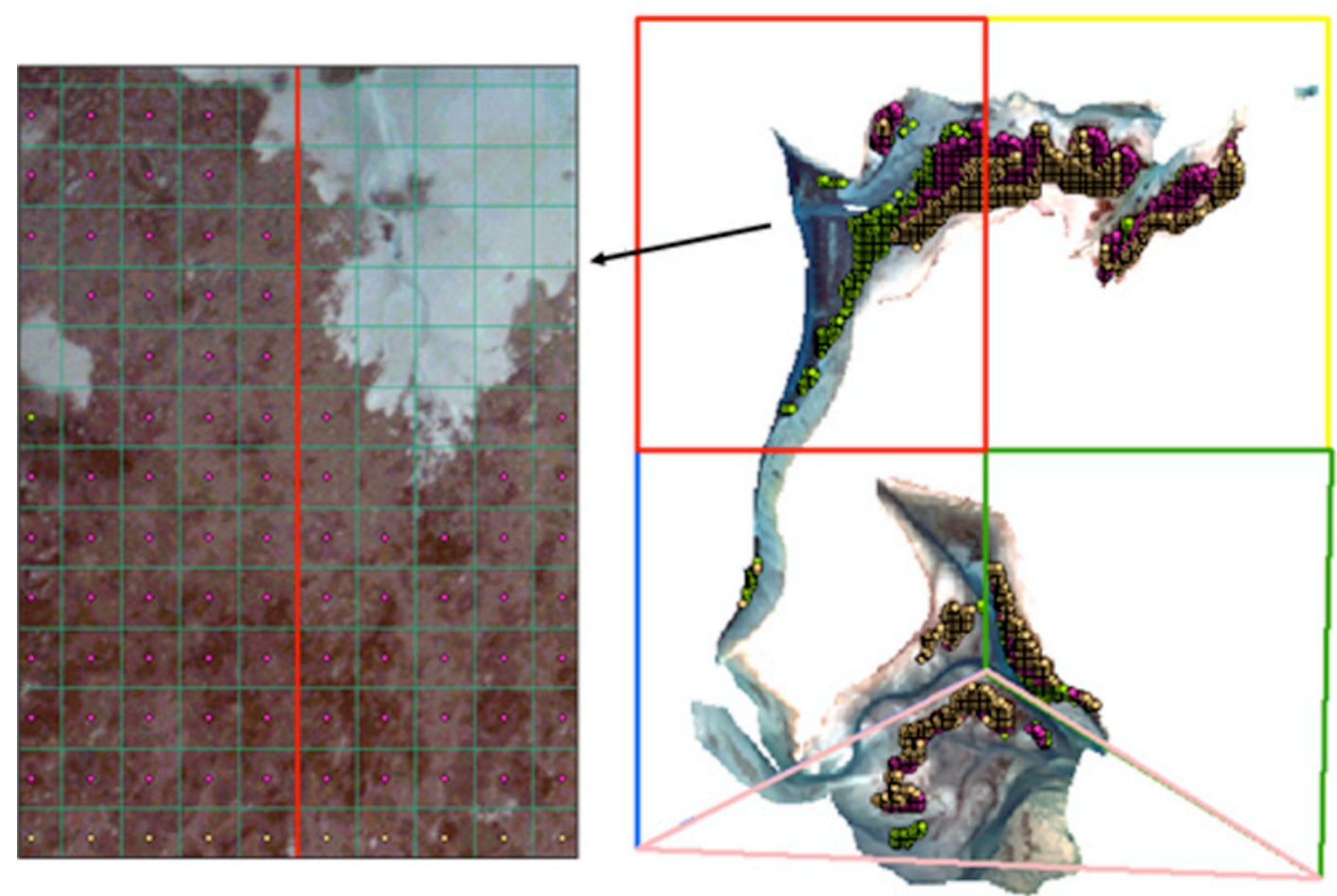

Figure 5.2. Fishnet distribution of sample grid cells $(50 \mathrm{~m} \times 50 \mathrm{~m})$ across the intertidal landscape.

Grid cells with a circle met the requirements for gap analysis, and were candidates for further cell-specific analyses (number and size of gaps, change analysis). The color of the circle represents different tidal placements based on ground surveys and visual interpretation: upper (yellow), middle (pink) and lower intertidal (green). 


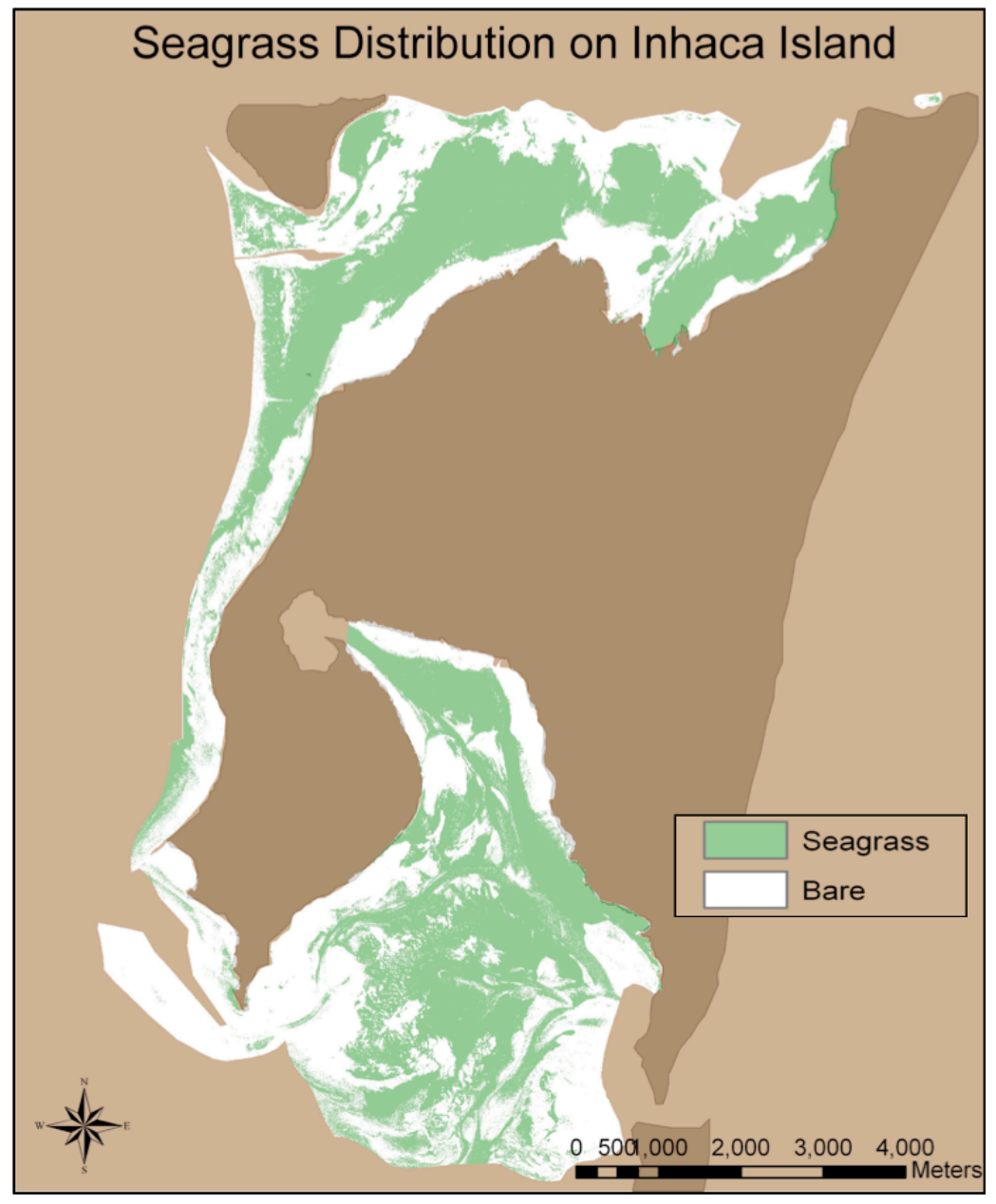

Figure 5.3. Classification map of seagrass distribution (intertidal and subtidal) using 2006 imagery. 


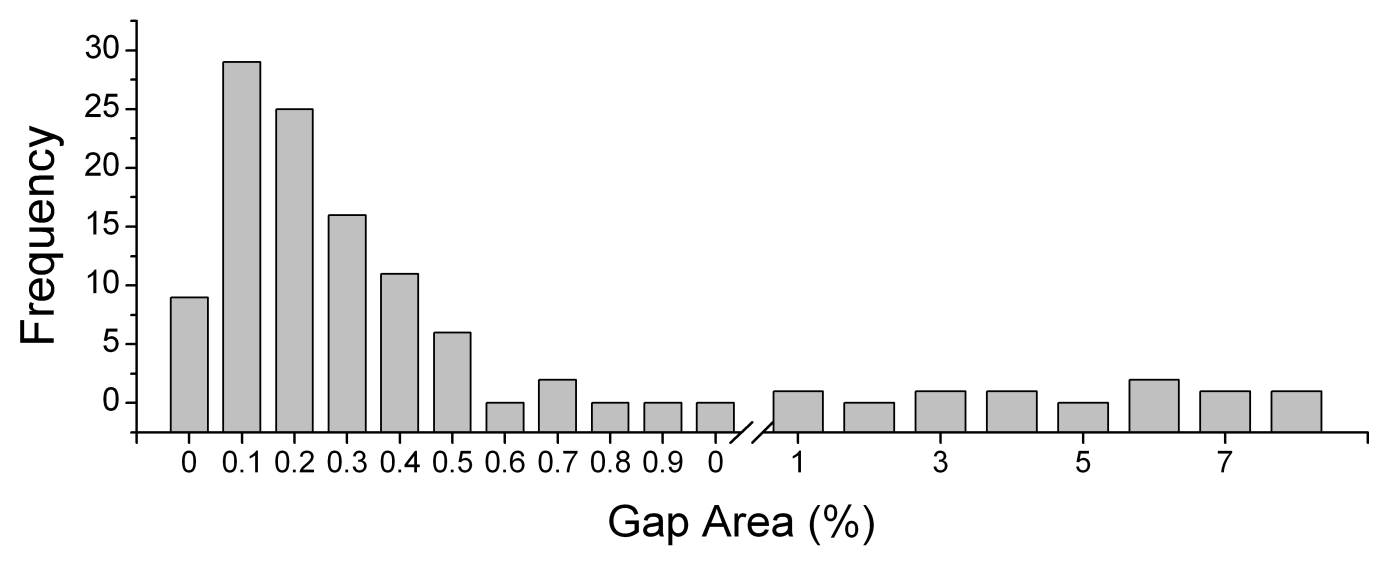

Figure 5.4. Frequency of grid cells with a percentage of area composed of bare gaps. $\mathrm{N}=90$. Grid cells are $50 \mathrm{~m} \times 50 \mathrm{~m}$.

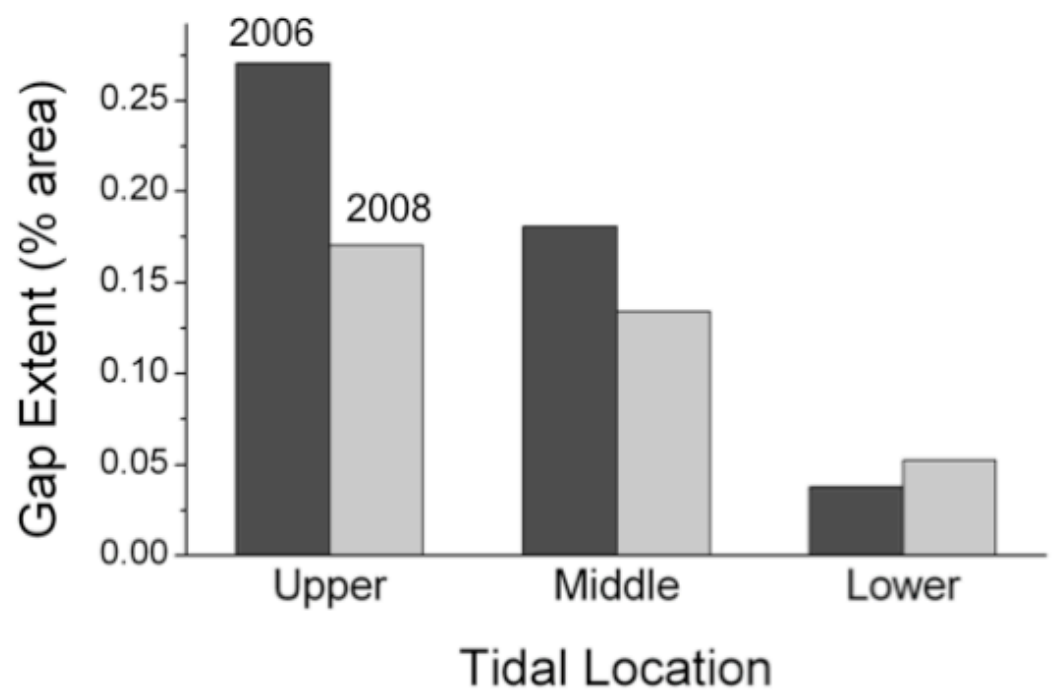

Figure 5.5. Percentage of area composed of gaps within seagrass meadows by tidal location as determined with 2006 and 2008 satellite imagery. 


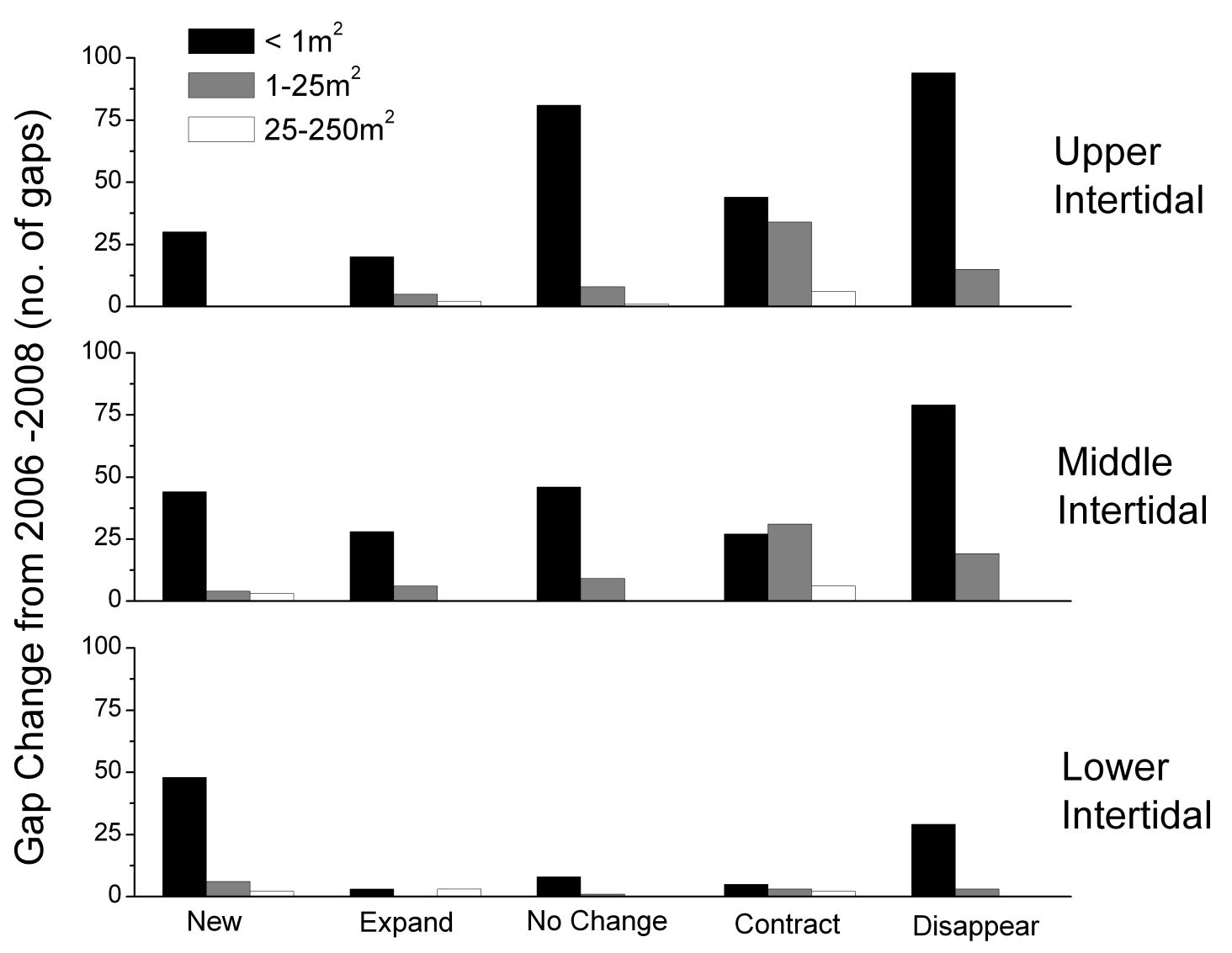

Figure 5.6. Gap dynamics from $2006-2008$.

Total number of gaps identified for each size class based on a comparison of 2008 with 2006 images. $\mathrm{N}=30$ of $2500 \mathrm{~m}^{2}$ sampling plots for each tidal location, for a total sampling area of $0.225 \mathrm{~km}^{2}$. 
Tables

\begin{tabular}{llccc}
\hline & & \multicolumn{2}{c}{ Class } & \\
& & Seagrass & Bare & Total \\
\hline \multirow{2}{*}{ Areal Extent } & Total Cover $\left(\mathrm{km}^{2}\right)$ & 21.14 & 19.63 & 40.77 \\
& \% Area of Intertidal & & & \\
& Zone & 51.85 & 48.15 & \\
\hline Classification & Reference Totals & 298 & 76 & \\
& Class Totals & 286 & 88 & \\
& Number Correct & 279 & 69 & \\
\hline Accuracy Indices & Producers (\%) & 93.62 & 90.79 & \\
& Users (\%) & 97.55 & 78.41 & \\
& Overall (\%) & & & 93.56 \\
& Kappa Statistic & 0.91 & 0.73 & 0.85 \\
\hline
\end{tabular}

Table 5.1. Seagrass classification map and accuracy assessment results.

\begin{tabular}{llccc}
\hline Location & & $\begin{array}{c}\text { Sample } \\
\text { Area }\left(\mathrm{m}^{2}\right)\end{array}$ & $\begin{array}{c}\text { Gap Area } \\
\left(\mathrm{m}^{2}\right)\end{array}$ & $\begin{array}{c}\text { Gap Area } \\
(\%)\end{array}$ \\
\hline \multirow{3}{*}{ Total } & 2006 & 225000 & 380 & 0.17 \\
& 2008 & 225000 & 271 & 0.12 \\
& Change & & -109 & -0.05 \\
\hline \multirow{3}{*}{ Upper } & 2006 & 77500 & 209 & 0.27 \\
& 2008 & 77500 & 132 & 0.17 \\
& Change & & -78 & -0.10 \\
\hline \multirow{3}{*}{ Middle } & 2006 & 77500 & 140 & 0.18 \\
& 2008 & 77500 & 101 & 0.13 \\
& Change & & -39 & -0.05 \\
\hline \multirow{3}{*}{ Lower } & 2006 & 77500 & 31 & 0.04 \\
& 2008 & 77500 & 39 & 0.05 \\
& Change & & 8 & 0.01 \\
\hline
\end{tabular}

Table 5.2. Total gap area $\left(\mathrm{m}^{2}\right)$ within seagrass meadows based on tidal location and percent change in area between the 2006 and 2008 imagery.

$\mathrm{N}=30$ grid cells $(50 \mathrm{~m} \times 50 \mathrm{~m})$ for each of the tidal location. Gaps identified were between $0-250 \mathrm{~m}^{2}$. This includes gaps $<250 \mathrm{~m}^{2}$ in size. 


\begin{tabular}{llccccc}
\hline \multirow{2}{*}{ Gap Size } & $\begin{array}{l}\text { Tidal } \\
\text { Zone }\end{array}$ & Expand & Static & Contract & Disappear & New \\
\hline$<1 \mathrm{~m}^{2}$ & Upper & 8 & 34 & 18 & 39 & 13 \\
& Middle & 16 & 26 & 15 & 44 & 24 \\
& Lower & 7 & 18 & 11 & 64 & 107 \\
& Total & 10 & 26 & 15 & 49 & 48 \\
\hline $1-25 \mathrm{~m}^{2}$ & Upper & 8 & 13 & 55 & 24 & 0 \\
& Middle & 9 & 14 & 48 & 29 & 6 \\
& Lower & 0 & 14 & 43 & 43 & 86 \\
& Total & 6 & 14 & 48 & 32 & 31 \\
\hline $25-250 \mathrm{~m}^{2}$ & Upper & 22 & 11 & 37 & 0 & 0 \\
& Middle & 0 & 0 & 100 & 0 & 50 \\
& Lower & 60 & 0 & 40 & 0 & 40 \\
& Total & 27 & 14 & 69 & 0 & 30 \\
\hline All gaps & Total & 14 & 14 & 44 & 27 & 36 \\
\hline $250 \mathrm{~m}^{2}$ & & & & & & \\
\hline
\end{tabular}

Table 5.3. Percent change of gap behavior between 2006 and 2008 based on intertidal zone and gap size.

$\mathrm{N}=637$ total number of gaps in 2006. 


\begin{tabular}{llccccc}
\hline & & Median & Mean & Mean SE & Min & Max \\
\hline \multirow{3}{*}{ Total } & 2006 & 568 & 3329 & 1901 & 327 & 28746 \\
& 2008 & 370 & 2602 & 1650 & 68 & 25237 \\
& Change (\%) & -35 & -22 & & & \\
\hline \multirow{3}{*}{ Upper } & 2006 & 538 & 2082 & 1315 & 364 & 7214 \\
& 2008 & 690 & 1222 & 584 & 334 & 3461 \\
& Change (\%) & 28 & -41 & & & \\
\hline \multirow{3}{*}{ Middle } & 2006 & 556 & 528 & 30 & 436 & 597 \\
& 2008 & 245 & 224 & 44 & 68 & 337 \\
& Change (\%) & -56 & -57 & & & \\
\multirow{3}{*}{ Lower } & 2006 & 797 & 7376 & 5458 & 327 & 28746 \\
& 2008 & 929 & 6359 & 4778 & 354 & 25237 \\
& Change (\%) & 17 & -14 & & & \\
\hline
\end{tabular}

Table 5.4. Descriptive statistics for large-scale gap area $\left(\mathrm{m}^{2}\right)$ within seagrass meadows based on tidal location.

$\mathrm{N}=5$ randomly selected gaps (at least $250 \mathrm{~m}^{2}$ in either 2006 and 2008) for each tidal location. This includes gaps $>250 \mathrm{~m}^{2}$ in size. 


\section{Appendix}

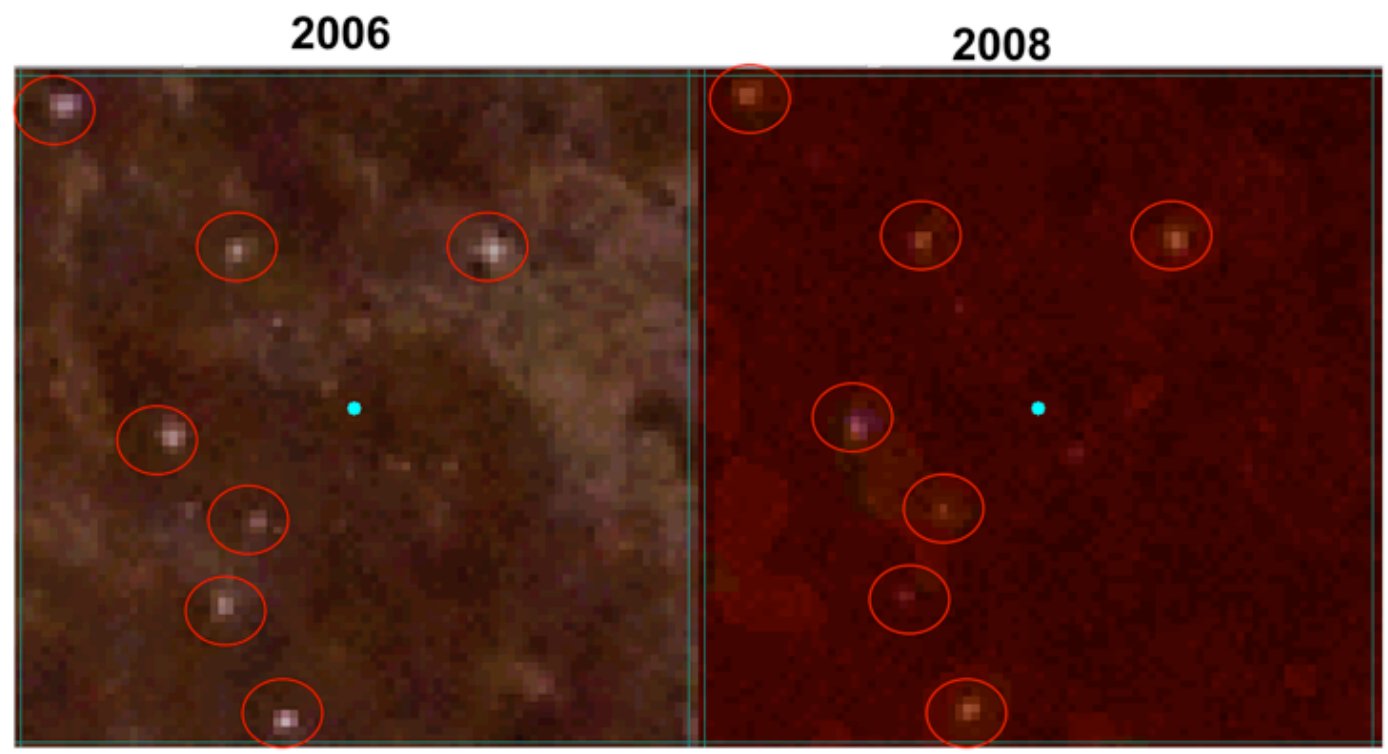

Appendix 5.1. Changes within one grid cell (50 m x $50 \mathrm{~m}$ ) between 2006-2008, with visible gaps circled. Pixel size is $0.6 \mathrm{~m} \times 0.6 \mathrm{~m}$.

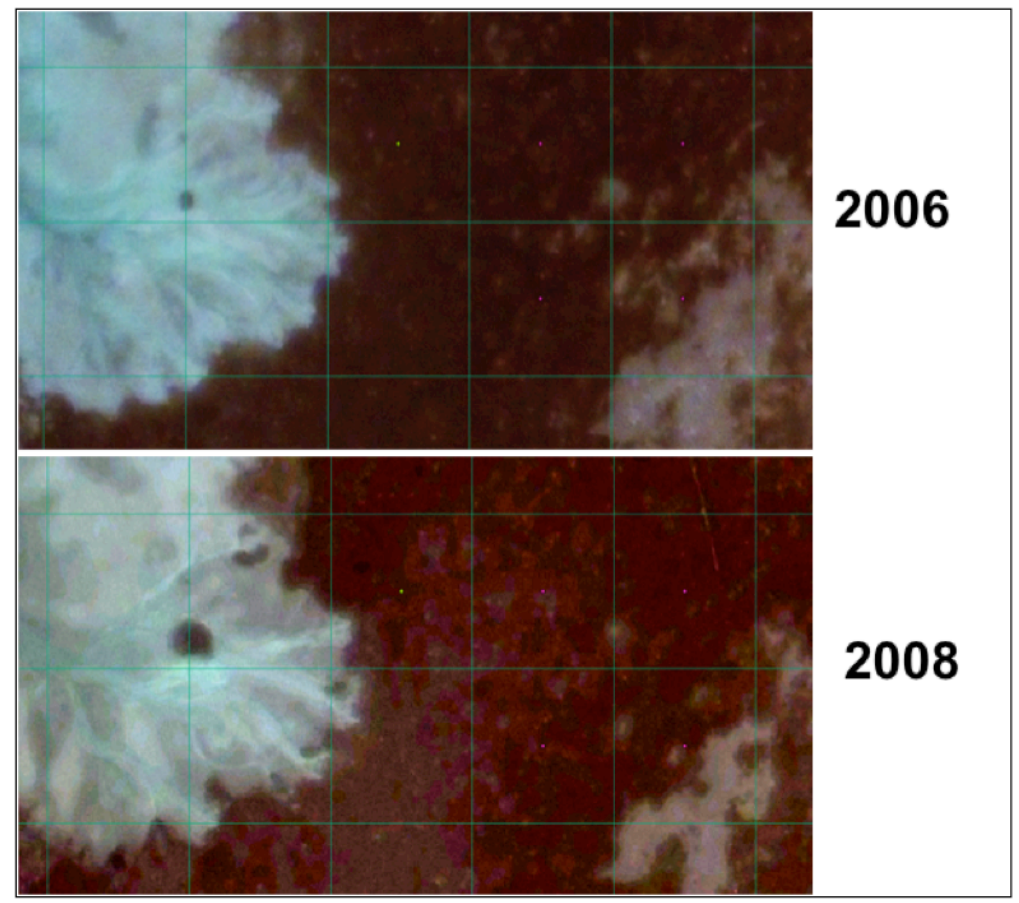


Appendix 5.2. Changes observed in along a patch edge from 2006-2008. Each delineated grid cell is $50 \mathrm{~m} \times 50 \mathrm{~m}$.

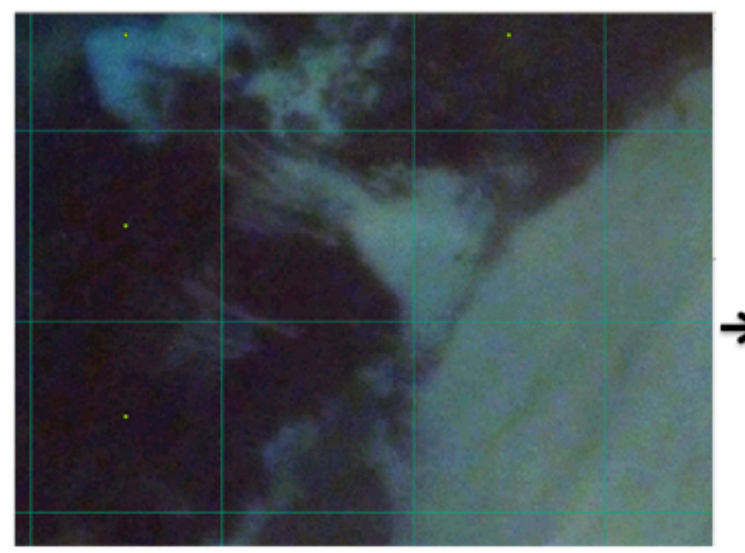

2006

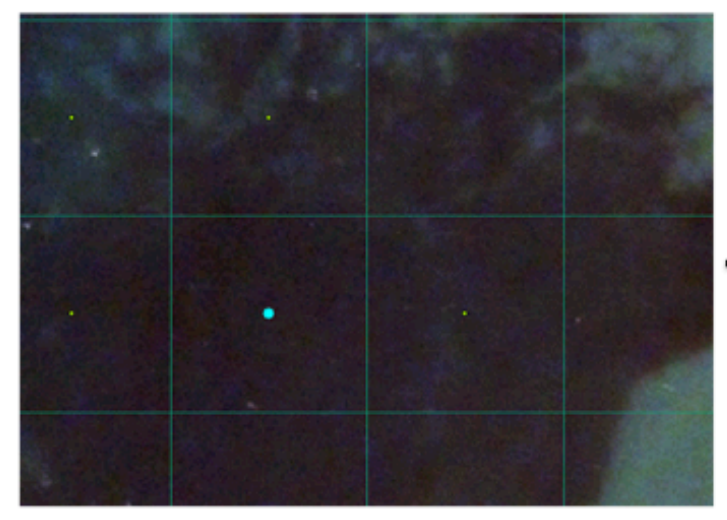

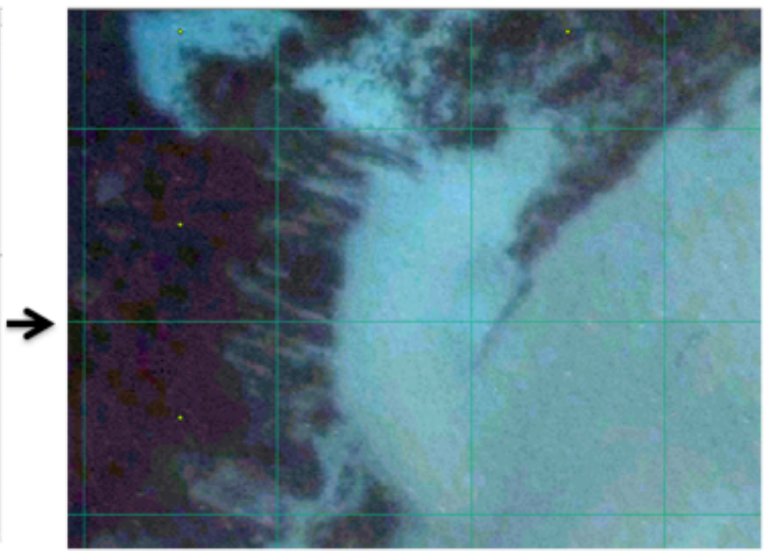

2008

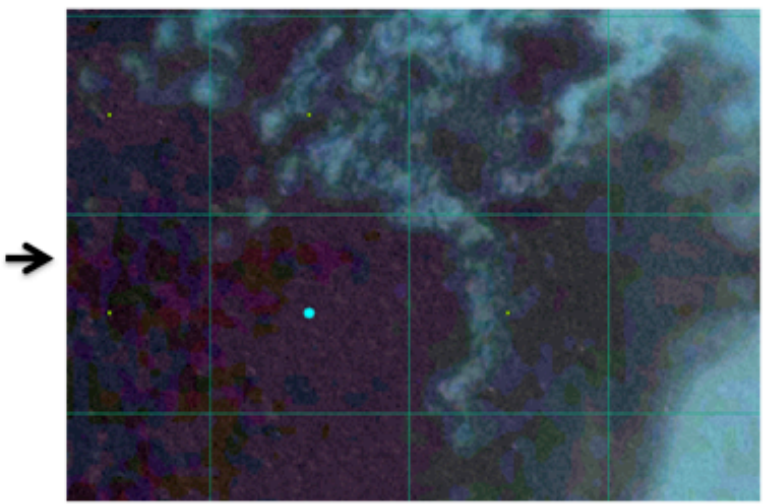

Appendix 5.3. Changes observed in selected areas from 2006-2008. Each delineated grid cell is $50 \mathrm{~m} \times 50 \mathrm{~m}$. 


\section{Chapter Six: Synthesis}

The ultimate goal of this work was to identify relationships between disturbances and seagrassess at the plant and landscape scale within intertidal zones. The following is an overview of the dissertation results based on general themes with brief responses to the original questions outlined in Chapter 1.

\section{Plant Patterns: Factors Regulating Seagrass Distribution and Abundance}

An original conceptual model is presented on how macro-scale (tidal gradient) and micro-scale (disturbance) physical factors, and possibly biological processes (interspecific competition), influence seagrass distribution and diversity simultaneously across a tidal landscape. The model emphasizes the importance of small-scale disturbances $\left(<1 \mathrm{~m}^{2}\right)$ for influencing habitat heterogeneity as a re-occurring theme throughout the dissertation. To my knowledge, this is the first study to quantify seagrass disturbance patterns across intertidal gradients, and to experimentally examine the applicability of ecological theories of diversity-disturbance (Intermediate Disturbance Hypothesis) within intertidal seagrass habitats. 


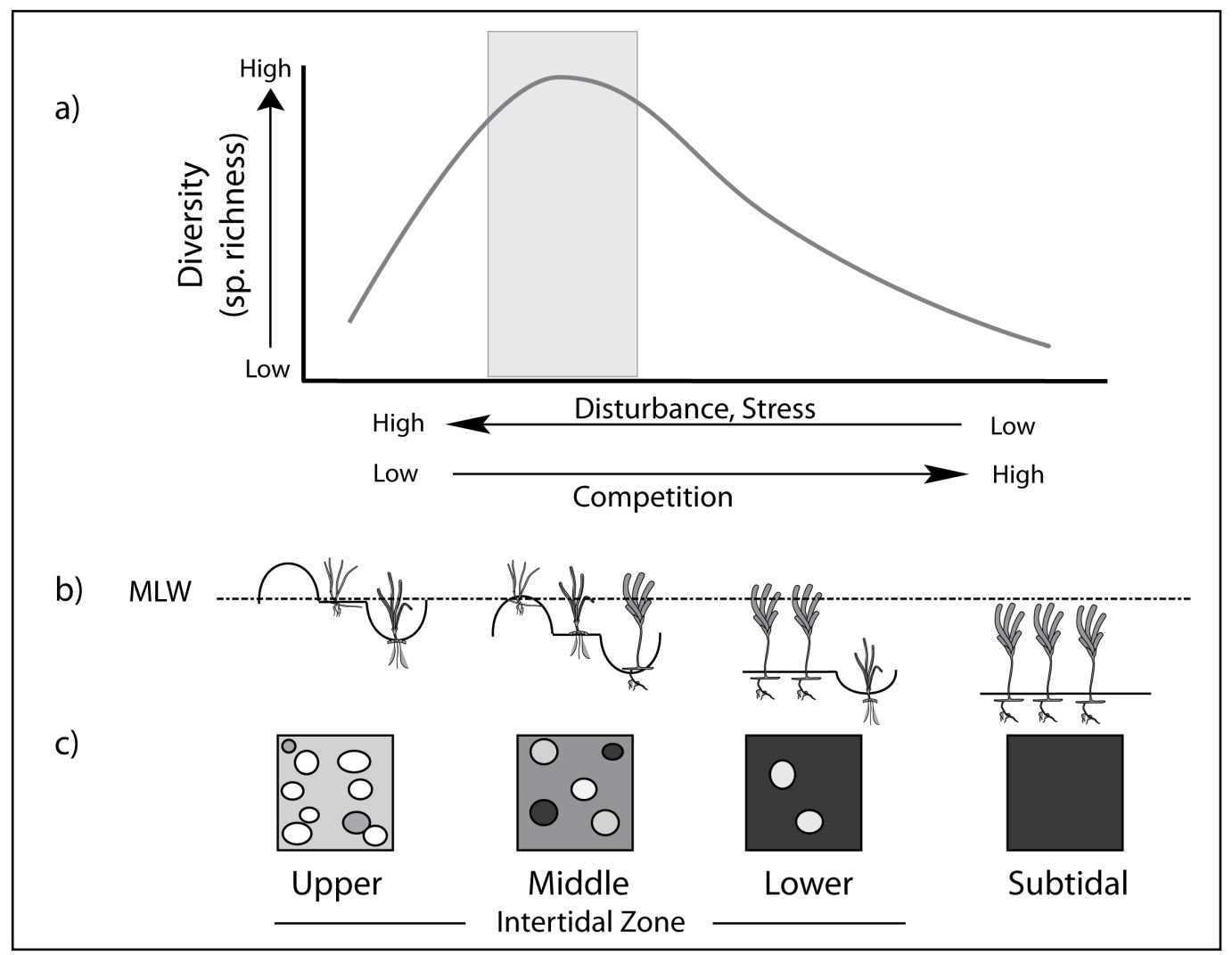

Disturbance-Diversity model along an intertidal gradient. Originally presented in Chapter 2.

1. What seagrass zonation patterns exist across the intertidal zone? A strong zonation of seagrass species exists along the intertidal gradient; smaller species (e.g. H. uninervis) dominated the upper intidal, and larger species (e.g. T. ciliatum) dominated the lower intertidal (Chapter 2). 
2. What disturbance patterns exist across the intertidal zone? Disturbance intensity decreased with depth. Small disturbances $\left(<0.5 \mathrm{~m}^{2}\right)$ created by bioturbation were common in the upper and middle intertidal zones (Chapter 2)

3. Is there a correlative relationship between disturbance and seagrass species diversity? Species diversity was highest in the middle intertidal (Chapter 2).

\section{Plant Dynamics: The Role of Disturbance and Seagrass Recovery}

While the survey provided a snap-shot of disturbance regimes across the intertidal gradient, experimentation was necessary to flesh out the theories that were presented in the disturbance-diversity model that I created in Chapter 2. For example, I put forward the notion that small changes in sediment depth following burial and excavation disturbances can affect landscape species diversity by altering the competitive outcome. While this experimental approach has been conducted in similar forms before, my experiments were the first to examine how disturbance responses vary based on tidal placement, and the first to examine the entire community response (sediment, fauna) rather than focusing only on seagrass plant metrics. The disturbance experiments described in Chapter 3 utilized an ecologically-realistic disturbance regime (size, depth of sediment burial/removal) that was identified in Chapter 2. Results from these experiments reveals how seagrass re-colonization process in mixed species intertidal meadows are complex. Also, that recovery prediction using simple seagrass succession models are limited and should incorporate specific disturbance types and tidal placement. These 
findings were useful in supporting the general hypotheses put forth in my model presented in Chapter 2; different types of disturbance may lead to shifts in species assemblages, which in turn can affect landscape diversity patterns.

1. What is the recovery trajectory (rate and direction) of seagrass and animals following experimental disturbances across the intertidal zone? The rate and direction of seagrass and fauna recovery following disturbance varied depending upon the intertidal location. The slow recovery at the middle intertidal was unexplained by species-specific growth rates, and the role of herbivory in affecting recovery at this site was explored with additional experimentation (Chapter 3).

2. How does the recovery trajectory vary based on disturbance type - burial or excavation? Effects of disturbance type was most noticeable in the lower intertidal, where the large slow-growing dominant seagrass exhibited high resistance to sediment burial, but low resilience to sediment removal (Chapter 3)

3. Does this experimental disturbance produce the same predicted results of seagrass species diversity that were identified in Chapter 2? If so, what is the mechanism? Disturbance may indeed influence community competition and species diversity, but several mechanisms appear to be involved. These mechanisms include a combination of species-specific resilience to disturbance, vegetative expansion by the original species, opportunistic invasion by new species, and changes in competitive outcome due to small modifications of standing water at low tide. 


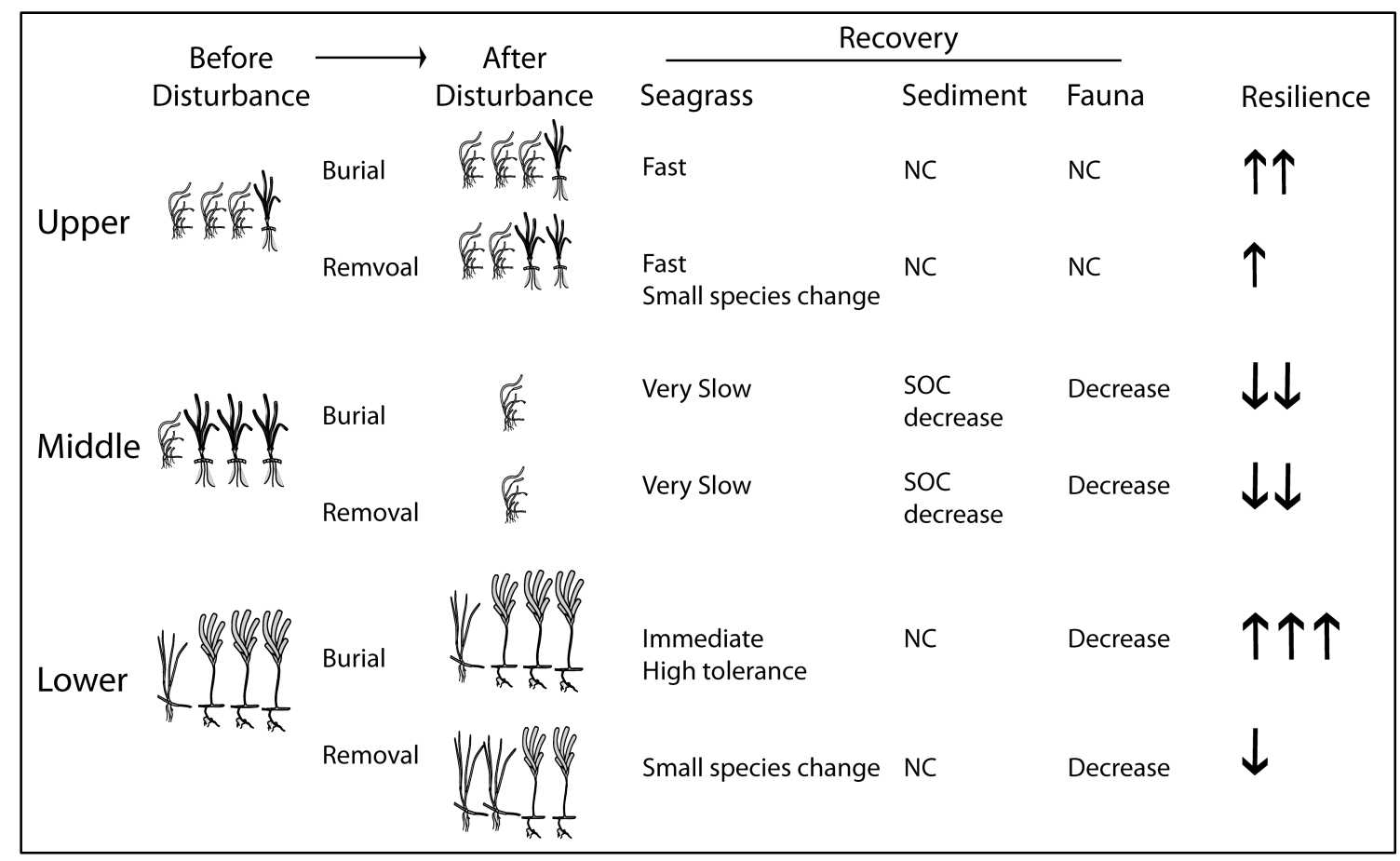

Summary of results by intertidal site (upper, middle, lower) and treatment (burial, removal). Originally presented in Chapter 3.

In addition to the type of disturbance (e.g. burial, removal), it has been suggested that other factors influence the rate and trajectory of seagrass recovery. Sediment organic content has been cited as one environmental factor that can affect seagrass growth. My experiments found no lasting significant effects of sediment organic content treatments (high, ambient, low) on any of our sediment or seagrass parameters after one year. I found the lack of an effect to be quite interesting as these results differ markedly from experimental studies in subtidal seagrass habitats that found negative affects on seagrass growth. This allows us to rule out sediment organic content levels as a primary driver of disturbance recovery at this location, and provides further support that additional factors 
other than sediment conditions, such as those discussed in Chapter 2 and 3 (speciesspecific growth strategies, resilience to disturbance, and physical factors unique to intertidal zones such as exposure), regulate seagrass recovery in these tropical intertidal meadows.

4. Does sediment organic content affect seagrass recovery? Sediment Organic Content of disturbed area does not appear to influence the rate or direction of recovery in intertidal communities, despite using experimental SOC values consistent with studies that did result in impacts (Chapter 4)

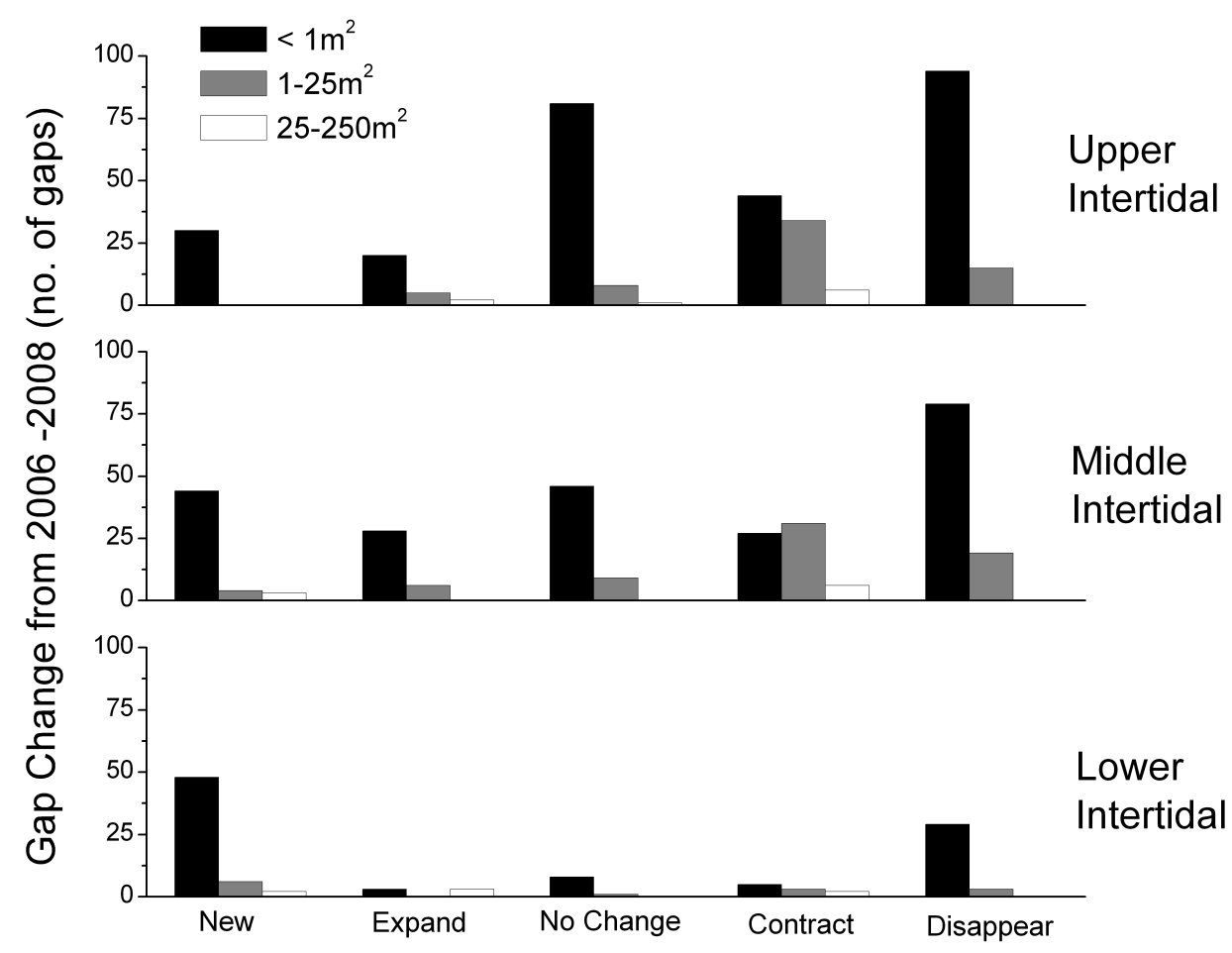

Gap Dynamics observed between 2006-2008. Originally presented in Chapter 5. 


\section{Landscape Dynamics: Disturbance Influence on Seagrass Heterogeneity}

The application of landscape ecology principles to seagrass ecosystems is a relatively recent phenomena Although small sized disturbances are common occurrence in the intertidal zone, there is little information on how they can influence landscape heterogeneity. We investigated spatial and temporal dynamics of disturbance-generated gaps within intertidal seagrass habitats using a novel technique for this purpose; highresolution satellite imagery. This is the first study to quantify small-scale seagrass gaps $\left(<10 \mathrm{~m}^{2}\right)$ and monitor how they change over time.

1. How do gaps that are created by disturbances within seagrass meadows change over a two-year period? Overall, the relative contribution of gaps is small using a remote sensing technique. However, these gaps were highly dynamic and constantly changing. I witnessed a combination of expansion, contraction, disappearance, no change and new gap creation over the course of two years (Chapter 5).

2. Does gap change over time differ along an intertidal gradient? (Chapter 5) Yes, with the upper intertidal being the most dynamic and having the greatest number of small sized $\left(<10 \mathrm{~m}^{2}\right)$ disturbances.

\section{Linking Plant and Landscape Processes}

One general result from both disturbance experiments (Chapter 3 and 4) was that the upper intertidal had the highest resilience to disturbance based on a full seagrass recovery within the shortest time frame (less than 2 years) as compared to other sites. Using this information, I can predict that most small-scale disturbances in the upper intertidal would 
be short lived and that they would experience a directional recovery - gaps would get smaller over time.

The resolution of the imagery used $(0.6 \mathrm{~m} \times 0.6 \mathrm{~m})$ was nearly identical to that of the experiments $(0.5 \mathrm{~m} \times 0.5 \mathrm{~m})$, which permits (with some limitations) the direct linking of plant with landscape scale attributes that is largely missing from the literature. I predicted that results from my disturbance experiments would be evident in my gap monitoring efforts, where small-scale gaps created by disturbances in areas with fast-growing species would tend to be relatively short-lived and closure would likely occur. Unexpectedly, I observed slow gap contraction and closure rates in areas dominated by fast-growing species (e.g. Halodule uninervis); $43 \%$ of gaps expanded or stayed static in the upper intertidal. This contradicts predictions based not only on experiment results in Chapter 3 and 4, but also goes against recorded seagrass growth rates and observed recovery rates that have focused on subtidal habitats. I attribute the persistence of these small gaps to a combination of continuous disturbance regimes (e.g. bioturbation and hydrodynamic activity) that are especially prevalent in these upper intertidal zones, and the inability for two-dimensional imagery to discern changes in sediment depth, which can also affect recovery based on results in Chapter 3 . This is also the first effort to quantify small-scale $\left(<10 \mathrm{~m}^{2}\right)$ gap changes over time. I demonstrate clearly that small-sized gaps $\left(<10 \mathrm{~m}^{2}\right)$ can persist for two years, and in some cases even expand, and therefore should be included in studies of spatial patterns and landscape dynamics. 
1. Are plant-level results represented at the landscape scale? The experiments in $\mathrm{Ch} 3$ and 4, along with species-specific growth rates, suggest that gaps in the upper intertidal would experience closure within the two-year time frame. However, we found nearly half of the upper intertidal gaps to remain the same size or even expand. This has not been described before, and may be related to the persistence of the disturbance (bioturbation). This highlights the difference between physical disturbances that is described in most other studies with biological disturbances. It also demonstrates that plant-level recovery dynamics are not always effective at predicting landscape level gap dynamics.

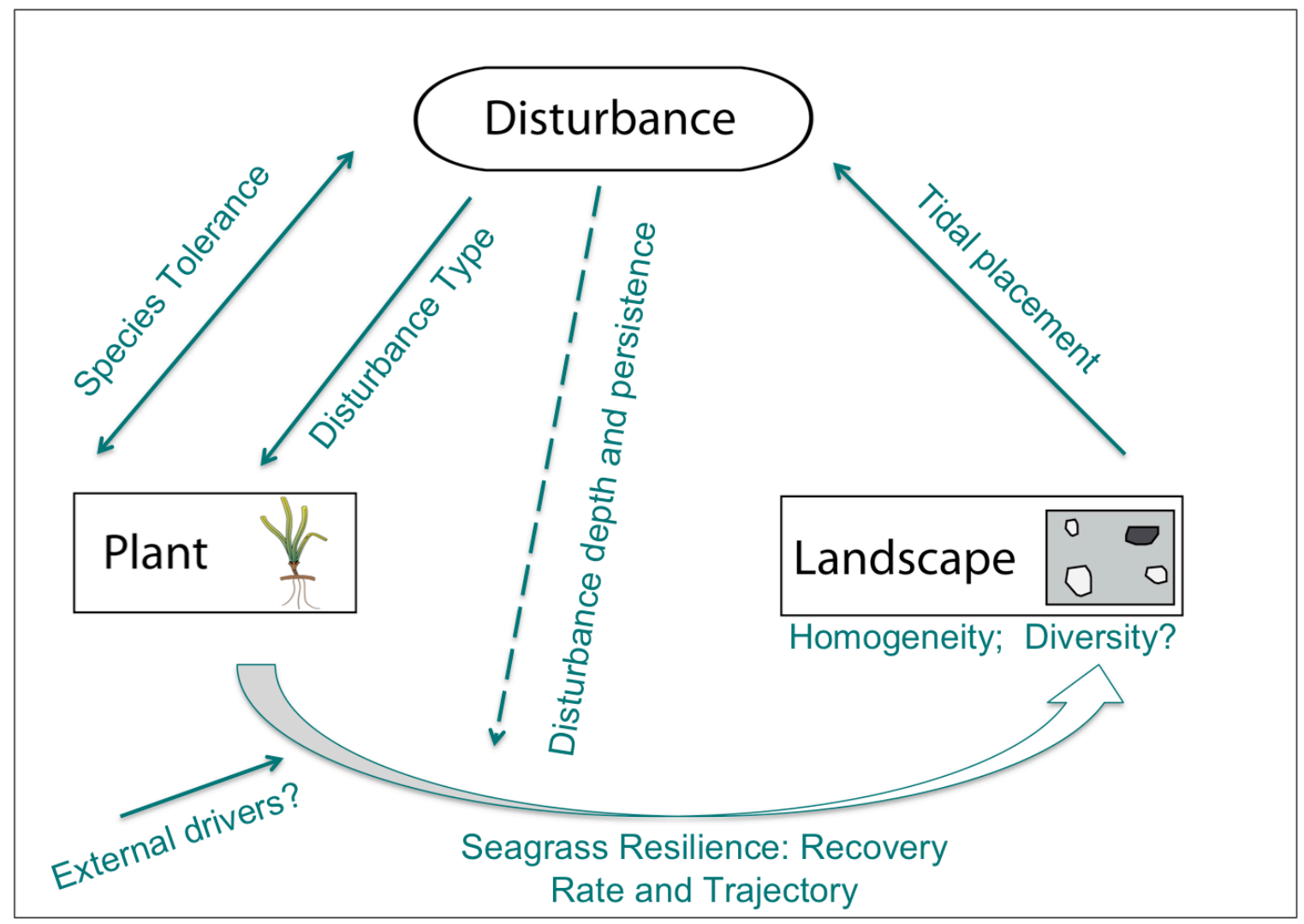

Figure 6.1. Completed conceptual model describing relationships between disturbance and seagrasses at the plant and landscape scales. 


\section{Linkage between chapters}

Despite very different research approaches within each chapter - from extensive field surveys to plant-level experiments to landscape dynamics - the chapters are highly connected and each one has some relevance to the other. For example, Chapter 2 influenced the development of questions addressed in Chapter 3, and Chapter 3 influence the development of questions addressed in Chapter 5. In addition to building upon chapters, results presented in one can offer supporting or contradicting evidence to conclusions presented in previous chapters. For example, Chapter 3 provided support in my disturbance model presented in Chapter 2, where as Chapter 5 provided results on gap dynamics that conflicted with those in Chapter 3.

\section{Future research direction}

Examples of appropriate follow-up would be to repeat the experiments from Chapter 3 for longer time periods, in order to determine if the initial changes in species composition observed are lasting. This would provide more evidence regarding how disturbances contribute to higher species diversity and coexistance in these mixed seagrass meadows (Chapter 2), which is a speculation that is often stated with certainty in the literature but in fact there is little data to support this argument. Another interesting follow-up would be to elaborate on the role of herbivory in regulating disturbance recovery by conducting similar tethering experiments in additional sites. This would help to identify whether the slow-recovery rate observed at the middle intertidal site was indeed site-specific and highly localized, or simply a reflection of the species present at that particular location. If 
the later is indeed true, this would indicate that the influence of herbivory in seagrass recovery is more expansive than originally suggested in Chapter 3. Predicting how seagrass communities change under different disturbance regimes is an important but difficult research endeavor, especially in speciose intertidal zones described in this study. However, using spatially explicit models that include below ground and sediment elevation components would further strengthen our ability to link plant and landscape processes. Other disturbance regimes (siltation, climate change) and potential scenarios of changes in existing disturbance regimes (increased small and large disturbance) could be explored. I would also be interested in pursuing questions related to the human utilization of these seagrass meadows, as well as explore further how different disturbance regimes affect the resident organisms that are so vital to the local population in East Africa. Finally, a comparison of disturbance and recovery with other coastal systems such as mangroves and corals would create a more holistic understanding of disturbance ecology across the tropical coastal seascape

\section{Summary}

In summary, this dissertaion contributes to our overall understanding of seagrass disturbance ecology, addresses specific knowledge gaps (see Chapter 1 for specifics), and presents some novel insights regarding disturbance within intertidal species-rich seagrass habitats. It is also one of very few efforts attempting to link plant and landscape-scale research on seagrass disturbance, and seems obvious that this particular effort is merely a beginning and much more work is needed. Finally, the data produced in this dissertation 
addressed and represented ecologically-realistic processes, which allows these results to be applied to a broad suite of topics, from the creation of predictive models describing seagrass disturbance and recovery, to specific restoration efforts and management efforts within tropical intertidal seagrass ecosystems both on Inhaca Island and around the world. 